\title{
“Marching Must Be Dignified": \\ The Government of Parades in Northern Ireland
}

\author{
by \\ Susan Salhany, B.A., M.A. \\ A thesis submitted to the Faculty of Graduate and Postdoctoral Affairs \\ in partial fulfillment of the requirements for the degree of \\ Doctor of Philosophy
}

\author{
Department of Sociology and Anthropology \\ Carleton University \\ Ottawa, Ontario \\ December 13, 2013 \\ (C) 2013, Susan Salhany
}




\begin{abstract}
$\underline{\text { Abstract }}$
In July 1996, public disorder associated with parades in Northern Ireland amounted to a significant crisis for the state. The result was the creation of an independent commission, known as the Northern Ireland Parades Commission, to manage how parades take place. This dissertation is concerned with the governing strategies and tactics deployed by the Parades Commission since its inception in 1997. It is concerned with the practical means through which the attempt was made to constitute the spaces and politics of parading as an object of government. Michel Foucault's study of governmentality, as well as the subsequent development of his work by other scholars, provides the overall approach to this thesis. I argue that in the mid-1990s, early attempts to repress, ban, and prohibit parading give way in important degrees to attempts to encourage, entice and direct the conduct of individuals and groups. The strategies, tactics, administrative procedures, and discourses deployed by the Commission aimed to capture and reorganize local symbolic politics and political relations in Northern Ireland in ways deemed conducive to peaceful parading. This study also concerns itself with the challenges, problems and resistances faced by the Commission. In particular, it takes into account the ways in which the lack of political consensus and the history of political conflict in Northern Ireland has shaped the governing project, as well as the ways in which the attempt to govern a symbolic display challenged the processes and practices of government. This thesis ultimately shows how the Commission's attempts proved unsuccessful: as evident by the constant challenges faced by the body, the spaces and politics of parading are elusive and difficult to constitute; the government of parades has required persistent experimentation which continues to present day.
\end{abstract}




\section{Acknowledgements}

Writing a dissertation is truly a collaborative effort and there are many I wish to thank.

I am deeply indebted to my supervisor, Bruce Curtis. Without his persistence, support, and guidance this thesis may not have been completed. I am especially grateful to Bruce for his enthusiastic engagement with my primary material and for his feedback throughout the writing process. His insights and advice were invaluable in providing a path to follow when I was confused and uncertain. When I lacked trust in myself, his unwavering faith in my abilities kept me writing.

I am also grateful to Andrea Doucet for her guidance and support through the early years; to Blair Rutherford for his always open door and upbeat encouragement; and to William Walters for agreeing to join this project and for his invaluable feedback on a draft of the thesis. Thank you all for your engagement with my work and for pushing my thinking in new directions.

There are many whom I met in Northern Ireland that made this thesis possible. I am indebted to Robin Whitaker who paved the way for fieldwork in Belfast by suggesting individuals I might contact, providing e-introductions, offering advice and helpful tips. Her kindness laid the basis for making my fieldwork experience an extremely rewarding one.

Special thanks goes to Dominic Bryan and Michael Hamilton. It is impossible to detail here all the ways in which they contributed to my research and my understanding of parades in Northern Ireland. Both generously gave their time, introduced me to other key individuals, and shared parade-related documents. Such documents provided a rich source of primary material which shaped the direction of the thesis. Dominic kindly invited me along on a flagcounting tour of County Armagh and provided a working space at the Institute of Irish Studies, while Michael introduced me to individuals within the Parades Commission and brought me with him to numerous parades. The thesis would not be what it is without their help and I cannot thank them enough.

I am also indebted to all those at the Parades Commission, including Authorised Officers and monitors, who gave me their time during my visits, allowed me to attend parades with them, patiently answered my questions, explained Commission procedures, offered their point view, provided various documents, and willingly helped out in any way they could. I am truly grateful. Similarly, I must thank all those involved in parading in various capacities who opened their door to chat with a Canadian graduate student about her research.

During the PhD journey, I had the opportunity to learn from established academics and faculty members, whether we met at Carleton, in Northern Ireland, or at various conferences. I especially thank Aaron Doyle, Martin Hand, Sean Farrell, Debbie Lisle, and Gordon Gillespie for their support, encouragement, and helpful exchange of ideas.

Dear friendships sustained me throughout the trials and tribulations of the $\mathrm{PhD}$ process. Special thanks go to my academic compatriots Christian Caron, Tara Lyons, Robyn Braun, Sophie Mathieu, Lindsey McKay, Tamy Superle, Jen Wrye, Darryl Ross, among many others. Thank you for listening, for sharing insights, productivity tips, and for cathartic nights out. 
Outside of academia, my profound thanks go to Lianne Kay and Jennifer Luck who over the years patiently listened to my academic woes, provided a sympathetic ear, home cooked meals, and good laughs to sooth my troubles.

My parents, Ron and Judy, provided unwavering support from the beginning. It is only because of them that I could undertake a $\mathrm{PhD}$ in the first place. When times were tough, they were always there for me with comforting advice and the occasional trip to Ottawa. I could not have done this without them.

Equally, I could not have finished this project without the love and support of my husband Mark. He took pride in my academic pursuits and encouraged me every step of the way. I am so fortunate to have him as a partner in life. To the wee one still growing inside my belly: You'll never know how much the excitement and happiness of your impending existence pushed me to finish this degree. This dissertation is for you.

Finally, I benefited from numerous sources of financial support for which I am grateful. Such support made this project possible: The Fonds de recherche du Québec, the Ontario Graduate Scholarship programme, the Ireland Canada University Foundation, the David and Rachel Epstein Foundation, the Faculty of Graduate Studies and Research, the Department of Sociology and Anthropology, and the Graduate Students' Association. Thank you. 


\section{$\underline{\text { Table of Contents }}$}

$\begin{array}{ll}\text { Abstract } & \text { ii }\end{array}$

Acknowledgments $\quad$ iii

List of Figures $\quad$ vi

$\begin{array}{ll}\text { Introduction } & 1\end{array}$

Chapter One 20

Governmentality, Investments and Political Experimentation: A

Methodological Discussion

Chapter Two

The Government of Parades in Northern Ireland: From Policing 'Public Order' to Governing 'Community Relations'

Chapter Three

The Birth of the Parades Commission and the Production of 'Contentious Parades'

Chapter Four

'The Art of Mediation': Mediation as a Strategy of Government

Chapter Five

Making Determinations: Mapping 'Contentious Parades' Through

Knowledge Practices

Chapter Six

Challenges and Transformations in Making Determinations and the Rise of a Human Rights Discourse

Chapter Seven

Governmentality, Political Conflict and Symbolic Displays: Challenges, Resistances and Governing Struggle

Conclusion 


\section{$\underline{\text { List of Figures }}$}

Figure 1 - 'The Commission in Action'

Figure 2 - A suggested 'scale of engagement'

Figure 3 - 'The 12-point Parade Scale'

Figure 4 - 'Ulster Says No!'

Figure 5 - 'You not allowed to parade either big lad?'

Figure 6 - 'Orangefest' advertisement 


\section{Introduction}

On July 12 1849, the Protestant marching organization, the Orange Order, marched through

Dolly's Brae, a predominantly Catholic village in County Down, Ireland. A group of Catholic men and women were determined that the procession not pass through the village and they assembled in a nearby field with various arms. Despite attempts by local priests to diffuse the tension and the encouragement by authorities that the Order re-route the march, a violent riot ensued. The riot left Orangemen unharmed, but 30 Catholics dead. The scale of disorder led the government to re-enact a law banning all party processions in Ireland (Farrell 2000: 1-4). The bill, titled $A$ Bill to Restrain Party Processions in Ireland, enacted on February 8 1850, stated:

Whereas Numbers of Persons have been in the Practice of assembling and marching together in procession in Ireland in a Manner calculated to create and perpetuate Animosities between different Classes of Her Majesty's Subjects, and to endanger the public Peace: Be it therefore enacted... That from and after the passing of this Act all Assemblies of Persons in Ireland who shall meet and parade together or join in procession, and who shall bear, wear or have amongst them or any of them any firearms or other offensive Weapons, or any Banner, Emblem, Flag or Symbol, the Display whereof may be calculated or tend to provoke Animosity between different Classes of Her Majesty's Subjects, or who shall be accompanied by any Person or Persons playing Music which may be calculated or tend to provoke Animosity between different Classes of Her Majesty's Subjects, shall be unlawful Assemblies, and every person present thereat shall be guilty of a Misdemeanor, and upon Conviction thereof shall be punished accordingly. (Hansard 13-14 vic. c2)

Almost a century and a half later, in July 1996, public disorder associated with parades in Northern Ireland amounted to a significant crisis for the state. On January 30 1997, the Secretary of State for Northern Ireland, Sir Patrick Mayhew, made a speech in the House of Commons:

Last summer, public disorder occurred in Northern Ireland on a very grave scale, associated in particular, but not exclusively, with a parade at Drumcree. Immense disruption was caused, with massive damage to property, including churches and schools. The murder of a taxi driver may also have been related. Deep and lasting injury was inflicted on both sides of the community, and on the Royal Ulster 
Constabulary, who were placed in an intolerable position. ... The improvement in Northern Ireland's image, which is so important economically in particular, was sharply reversed.

In the light of those shocking events, I announced on 15 July the establishment of the review, with the task of making recommendations about the future management of controversial parades.

The report is a long and closely argued document, with more than 40 recommendations. It proposes, as the foundation of its other recommendations, that seven fundamental principles should form the basis for the development of processes and procedures governing parades. I should say immediately that the Government accept those principles, which include both the protection of the right to peaceful free assembly and the need to ensure-preferably through local accommodation - that the exercise of that right takes proper account of foreseeable effects on relationships within the community.

We recognise the report's description of the parades issue as a microcosm of the wider political problems of Northern Ireland, and as one that has the capacity to polarise the community and to engage levels of emotion and commitment that few other issues reach.

The events of last summer cast a pall of fear across Northern Ireland. As the report states, an abyss of anarchy opened up. All people of good will must surely demand that there be no repetition, but no mechanisms and no procedures can be enough on their own.

There needs to be within all who live in Northern Ireland the will and the personal determination that last year's terrible events shall never again occur. To that end, the Government pledge that they will play their own part to the full. (Hansard, vol 289 cc 507-22)

As is evident by the two accounts, parading in Ireland, and later Northern Ireland, has long been a problem for the state. Parading in Ireland in the $19^{\text {th }}$ century was seen as a source of public disorder, which caused tensions, animosity and ill-will between Catholics and Protestants. When rioting and disorder reached unacceptable levels, law was brought to bear to ban processions. In $20^{\text {th }}$ century Northern Ireland, while parading was still seen as a source of disorder, it was thought about and addressed in a different fashion. How parading took place was understood as a 'microcosm of the wider political problems in Northern Ireland', problems which, in the mid-1990s, the British state was concerned to address through democratic dialogue. The solution to 'controversial parades' was to be found in 'the protection of the right to peaceful free assembly', while ensuring that 'the exercise of that 
right takes proper account of foreseeable effects on relationships within the community'. In other words, rather than prohibit parades, it was now to be about enabling parades to take place in a particular manner, such that events might occur without conflict.

The report mentioned by Mayhew is known as the North Report, and it made a total of 43 recommendations to deal with the problem of parading. The new strategy was to be implemented not through law alone, but through the creation of an independent commission, to be known as the Parades Commission for Northern Ireland, to manage how parades take place. The goal of the new regulatory mechanism was to foster a 'local accommodation', where parties engage in dialogue and come to some agreement among themselves on a disputed parade. In cases where self-government was not successful, the Commission was to, using a human rights framework, impose a legally binding decision regarding how a parade may or may not proceed.

This dissertation adopts the position that the development of the Parades Commission is less a solution to the political problems in Northern Ireland than a strategy of government. As such, this dissertation is concerned with the governing strategies and tactics deployed by the Northern Ireland Parades Commission since its inception in 1997 to present day. It is concerned with the practical means through which the attempt was made to constitute the spaces and politics of parading as an object of government. This study also concerns itself with the challenges, problems and resistances faced by the Commission. In particular, it takes into account the ways in which the lack of political consensus and the history of political conflict in Northern Ireland has shaped the governing project, as well as the ways in which the attempt to govern a symbolic display challenged the processes and practices of government. In highlighting the Commission's challenges and the context of 
conflict, this study understands governing as a dynamic process, where governing bodies are part of a wider field of struggle.

This dissertation advances the thesis that in the mid-1990s, early attempts to repress, ban, and prohibit parading give way in important degrees to attempts to encourage, entice and direct the conduct of individuals and groups. The strategies, tactics, administrative procedures, and discourses deployed by the Parades Commission aimed to capture and reorganize local symbolic politics and political relations in Northern Ireland in ways deemed conducive to peaceful parading. While everything is symbolic to some degree, not all symbols are problematized politically. I consider the symbolic to be a fluid, tacit, and intangible sphere of social relations, which had to be constituted; that is, made 'real' or rendered tangible in some form, in order for the Parades Commission to govern how parading took place. This thesis ultimately shows how the Commission's attempts proved unsuccessful: as evident by the constant challenges faced by the body, the spaces and politics of parading are elusive and difficult to constitute. The government of parades has required persistent experimentation, which continues to present day. After extensive rioting and violence following one particular parade in Belfast in the summer of 2013, the government appointed U.S. diplomat Dr. Richard Haass to chair all-party talks to the deal with the issue of parades, flags and emblems, and the legacy of the past. The talks are on-going at the time of writing.

By 'govern', I mean the understanding elaborated by Michel Foucault (2003a), where, most broadly, to govern means to direct the conduct of oneself or others towards certain ends deemed desirable, whether undertaken by oneself towards oneself, an individual towards another or others, or by state bodies towards particular groups. Foucault's study of governmentality, as well as the subsequent development of his work by other scholars, 
provides the overall approach to this thesis. A governmentality framework is useful for considering the concrete ways in which the Parades Commission attempted to know and calculate (or capture and reorganize) parading practices in Northern Ireland, with concern for the techniques, strategies and tools used to do so.

While the theoretical foundations for this project are further elaborated in the following chapter, it is worth noting now that, in addition to governmentality, I adopt the concept 'investment in forms' in order to help theorize the work of governing bodies. The concept was originally developed by Laurent Thévenot (1984), and it has been further elaborated in the science studies literature (see Curtis 2000, 2001; Desrosières 1990). The idea of 'investment' allows us to think how something not readily observable comes to appear concrete, tangible, or 'real', such that it may be acted on. Parading must be 'invested' through certain tools such that it appears in some practical form, such as through statistics, laws, or other categories and classifications. It is only once invested as such (made objects of action) that governmental interventions may be advanced.

\section{A brief history}

The state of Northern Ireland was born in 1921 when, after decades of violence between English Protestant settlers and Irish Catholic inhabitants, the conflict was resolved by dividing the island of Ireland in two, known as 'partition'. The southern 26 counties would become the independent Republic of Ireland, while the northern 6 counties would become Northern Ireland and remain part of the United Kingdom. With 430,000 Catholics trapped in the new geographical arrangements, along with 820,000 Protestants, the new state of Northern Ireland was formed amid violence, disorder, and discontent (Darby 1976: 9). Since its inception, Northern Ireland has been plagued by the intense polarization of two communities: the Irish Catholic minority, also referred to as nationalists, which desires both 
a united Ireland and an end to British rule, and the British Protestant majority, also referred to as unionists, which prefers partition and remains loyal to the British crown. ${ }^{1}$ This is where most stories about Northern Ireland and its present day conditions begin. Over the years, the sectarian tension and extent of integration or segregation between these two groups has waxed and waned, but it has always permeated social, cultural and political existence.

Central to the conflict is the legacy of economic disparity between Catholics and Protestants. After partition, Catholics faced discrimination in all areas of social life, from education, employment and housing, to policing and the administration of justice. It was events surrounding the civil rights campaign and the demand for equal treatment that is thought to have sparked the beginning of what is known as 'the Troubles'. The Troubles span from 1969 to 1994 and are a period marked by intense sectarian violence, paramilitary strength, and the polarization of the two 'sides'. Having deemed the Northern Ireland government unable to control the situation, in 1972, London invoked its powers to impose direct rule from Westminster. ${ }^{2}$ The long history of political and ethnic conflict and the varied ways in which the British government has dealt with it, most notably with the use of extreme measures and sovereign force, have left an institutionalized past which continues to shape local society and state-civil society relations.

The years after 1994, when paramilitary ceasefires were declared, are marked by the ups and downs of negotiating peace. For the first time in 1998, the 'politics of inclusion' were reflected in the decision to incorporate all political parties, including Sinn Féin, in the

\footnotetext{
${ }^{1}$ The terms 'nationalist' and 'unionist' represent political positions. Catholics/nationalists may also be referred to as 'republicans' which tends to designate those with more extreme political views, those who are staunchly committed to a united Ireland, and who may be willing to use both political and violent means. Similarly, Protestants/unionists may be referred to as 'loyalists' which also tends to designate the more extreme political position.

2 Stormont is the government of Northern Ireland, distinct from the Dail in Dublin and Westminster in London.
} 
peace process. Sinn Féin is an Irish Republican party, historically associated with the Irish Republican Army (IRA). The party's objective is to achieve a united Ireland and to see an end to British rule, and as such, it has long been kept out of formal governmental negotiations. The multi-party talks resulted in the successful passing of the 1998 Belfast Agreement, also know as the Good Friday Agreement, ${ }^{3}$ which set up a new power-sharing arrangement among Britain, the Republic of Ireland, and the Northern Ireland Assembly. The Agreement was based on the principle of 'accommodation', where the two major communities were envisioned as culturally distinct, but equal. The Agreement is generally understood to mark the end of violent conflict and the beginning of governmental reform. In particular, it called for independent commissions to review issues such as policing and the criminal justice system (Hillyard and Tomlinson 2000: 395-396). Parades, the start of the crisis, and the establishment of the Parades Commission Since 1872 when parades were legalised, parading in Ireland has been firmly embedded as a cultural practice, social event, and an important part of the political process (Jarman 1997: 28). In Northern Ireland, from April to August every year, during what is known as the 'marching season', thousands of parades take place all over the country. On average, there are between 3000 to 3500 parades each year. Out of this number, the majority are unionist or loyalist marches, associated with Protestants, while only a few hundred parades are nationalist or republican marches, associated with Catholics. The majority of parades are organized by three Protestant institutions which form part of 'the Loyal Orders'. The largest organization is the Orange Order. The Order was formed in 1795 and it has historically been involved in sectarian clashes. While it is religious nature, it is equally a political institution in that members have strong ties to unionist political parties. The Order is organized in 'lodges'

\footnotetext{
3 The Agreement was reached on Good Friday, April 101998.
} 
across Northern Ireland. Members pay annual dues and the lodge functions similar to a community group. The second member of the Loyal Orders is the Royal Black Institution, which is smaller, less overtly political, and the most religious. The third organization, and the smallest, is the Apprentice Boys of Derry.

The other group that organizes the majority of parades are marching bands. Bands are independent, self-formed groups which arrange their own parades, and marching band competitions, as well as being hired by the Loyal Orders to accompany their parades (Bryan 1996: 1-14). Parades range in size and scale and are organized for a variety of purposes, however, the larger annual parades are most commonly organized to commemorate key historical events. Historically, many Loyal Order parades have been considered 'traditional' in that they take place every year, occur on or around the same date, and follow the same route.

One of the largest celebratory occasions for Ulster Protestants is the anniversary of the Battle of Boyne. On July 12 in 1690, a Protestant King defeated an English Catholic King and the event is "thus perceived by Protestants in Northern Ireland to have secured the[ir] civil rights and religious liberties... within a predominantly Catholic Ireland" (Bryan 2000: 3). Hundreds of parades, many organised by the Orange Order, take place all over Northern Ireland on and around the $12^{\text {th }}$ of July commemorating the Battle of Boyne. When part of the route followed passes through a predominantly Catholic residential area, the march is highly disputed. Parade organizers have vehemently asserted their right to assemble, while largely Catholic and nationalist residents have claimed the right to prevent loyalist marches through 'their' areas, arguing they are a form of intimidation and harassment. While 
contentious parades are relatively few in number, ${ }^{4}$ they tend to involve protests, riots and disorder resulting in damage to property. The Protestant Drumcree Church parade, which takes place in Portadown, County Armagh, has been particularly disputed. In the summers of 1995 and 1996, when, to follow 'tradition', Orangemen walked down the Garvaghy road, now largely a Catholic area, the event led to violent confrontations.

Prior to the advent of the Parades Commission (PC), any disorder that erupted at parades was to be dealt with through reactive policing and the use of Public Order laws, as well as local negotiation, which was often unsuccessful. In the early 1990s, "[m]ost often, the decision whether to allow the parade to take place or to re-route it was left to the last minute and was determined by which side had mobilized the largest crowd of supporters" (Jarman 1999: 1422-3). After haphazard policing in 1995, re-routing parades in some areas, forcibly removing protesters in others, it became clear to all involved that the greater the threat of disorder, the greater the likelihood 'your side would get their way'. Discontent came to a head on July 9 1996, when the Royal Ulster Constabulary (RUC) decided not to allow marchers to walk down the Garvaghy road. Over the next three days, protests, rioting, violence, and destruction of property took place across Northern Ireland in support of the march and, on July 11, the chief of police reversed his decision. The British government sent in over 1000 soldiers to control what it saw as extreme disorder, nationalist residents were held back from the road, and the march was allowed to proceed (Bryan 2000). The following days saw rioting and violent protests in nationalist areas. In the context of the then current peace talks, the parading dispute assumed new political significance and, as Jarman stated, it was finally clear that "the current means of adjudicating over contested parades would need to be reviewed” (1999: 1425). In August 1996, the government launched the Independent

${ }^{4}$ For instance, from April 2008 to March 2009, the Parades Commission received notification of 3,801 parades, of which 221 were deemed contentious (PC Annual Report 2010: 10). 
Review of Parades and Marches, which led to the publication of the North Report (1997). The main recommendation of the report was the creation of a Parades Commission to govern how parades take place.

In October 1997, the government published the Public Processions (Northern Ireland) Act 1998, which laid the basis for the formation of the Commission. The Act dictated that the Parades Commission was to have a chairman and not more than six appointed members, and it set out its aims, duties, and responsibilities. Its main role would be to consider notified parades on a case by case basis, and where deemed 'contentious', the Commission was to work to facilitate a local accommodation, mainly through promoting mediation. A local accommodation involved parties coming to some agreement among themselves regarding the dispute. Only failing such agreement would the Commission impose a 'determination': a legally-binding decision which outlined the conditions under which a parade may take place. Such decisions were produced in writing and posted to the Parades Commission website.

Central to both promoting mediation and making determinations were individuals hired by the Commission known as 'Authorised Officers' (AOs). AOs were to work 'on the ground' in different localities to facilitate agreements among parties in parade disputes. AOs were trained as mediators and used these skills in their work. In terms of making determinations, the Commission undertook a variety of 'evidence-gathering' practices, of which AOs were also central. To collect the information deemed necessary, AOs were to go to the locality in which the parade was to take place, and take note of the 'demographic mix' in the area, which in practice meant noting the balance between Protestants and Catholics; they were to record "any landmarks of sensitive historic significance" on the notified parade 
route; and they were to speak with and collect the views of residents, among other evidencegathering tasks (PC Procedural Rules 1998: 2.1).

Since its inception, the Parades Commission has been a controversial and contested body. The Orange Order in particular has officially refused to engage with it, making finding local agreements to disputes difficult. As there has never been a consensus on the governing procedures for parades, the Parades Commission has been subject to numerous governmental reviews. Reviews range from attempts to improve the Commission, to proposals to disband the Commission and replace it with entirely new procedures. The life and work of the Parades Commission, and the struggle on the part of the state to find consensus among political parties, must be understood in the context of the developing peace process and the new power-sharing arrangements for the government of Northern Ireland.

\section{Recent governmental attention to symbols: Locating the Parades Commission}

The Parades Commission may be located more broadly in a general rise of governmental attention to symbolic displays. In Northern Ireland, there is a long history of conflict over rituals and symbols, particularly parades and flags, much of which is well documented (Rolston 1991, 2012; Jarman 1993; 1997; Bryson and McCartney 1994; Bryan 2000; Santino 2001). Historically, such clashes and the extent of display and protest largely ebbed and flowed in accordance with the political climate at the time (Jarman 1999) and were dealt with as they arose. However, emerging in the literature on Northern Ireland is a recognition that since the start of the peace process in 1994 and with the advent of 1998 Belfast Agreement, symbols occupy a more central place in public discussions and governing discourses (MacGinty and Darby 2002; Brown and MacGinty 2003; Bryan and McIntosh 2005, 2007; Hill and White 2012). Writing in 1999, Jarman states that "[o]ver the past four 
years... disputes over the right to march, the expression of cultural traditions, and the displaying of symbols, emblems, and regalia have grown in significance and have often dominated the political agenda" (Jarman 1999: 1415).

With the advent of the 1998 Belfast Agreement, while no specific mention of parades or flags was made, symbols formally came into question:

All participants acknowledge the sensitivity of the use of symbols and emblems for public purposes, and the need in particular in creating new institutions to ensure that such symbols and emblems are used in a manner which promotes mutual respect rather than division. Arrangements will be made to monitor this issue and consider what action might be required. (NIO 1998: 20)

On the one hand, the Agreement stressed recognition of cultural diversity, and at the same time, the hope for finding new and 'more inclusive forms of belonging' (Bryan and McIntosh 2007: 125). Brown and MacGinty write that "[t]hrough the Belfast Agreement, Northern Ireland was presented with a unique opportunity for the creation of new, neutral, and consciously non-partisan symbols" (2003: 85). The Agreement distinctly linked symbols to identity, and in particular, as potentially working further to entrench partisan identities, and as damaging to inter-community relations. Since then, "a range of agencies have attempted to modify the use of symbols, either by drawing upon the 'two traditions model' and 'parity of esteem' or by promoting neutral or shared space through the exclusion of symbols or the invention of new symbols” (Bryan and McIntosh 2007: 135).

One may point to several political interventions that reflect the preoccupation with symbols as a statement of identity. The review of policing and the subsequent recommendations in the 1999 Patten Report on policing reforms led to the renaming of the police from the 'Royal Ulster Constabulary', which signifies ties to Britain, to the more neutral 'Northern Ireland Police Service'. In addition to the new name, the emblems on the uniforms have also been changed - "the new badge incorporates the scales of justice, harp, 
torch, laurel leaf, shamrock and crown" to symbolise the diverse communities (Thompson 2003: 18). More recently (2006-2010), the government has commissioned a series of census reports on the display of flags, on the basis that flags represent the strength of identity attachments, and it is thought that determining when and for how long they are flown (i.e.: during annual holidays or longer), reflects whether they are for commemorative purposes or intended, more 'problematically', as territorial markers (Bryan and Gillespie 2005; Bryan, Stevenson and Gillespie 2008, 2009, 2010; Bryan et al. 2011).

Finally, as another example, massive government funding was given to the Northern Ireland Arts Council for projects such as the 2006 'Re-Imaging Communities Programme', where political murals were replaced with more neutral images relevant to both major communities (see Rolston 2012; Hill and White 2012). A 2009 report on the programme explained the problem of symbols as public representations of the community which make manifest divisions, conflict and sectarianism. The report states: "In particular, the public representation of the community separation has taken the form of a widespread and often remarkable incidence of public symbolic displays, including marches, banners, flags, wall paintings, bunting, and painted kerbstones. These displays are normally sectarian, antagonistic and offensive, and are intended as visible and unambiguous statements of opposition and aggression” (Independent Research Solutions 2009: vi-vii).

Such a characterization of symbols was not always the case in Northern Ireland; symbols were not always seen as a problematic manifestation of conflict between two groups. Rather, for a period of time since partition through to the Troubles, based on the way symbols were treated by police and state, symbols were once either legitimate expressions of the state (unionist displays), or they were illegitimate expressions against the state (nationalist displays). In either case, symbols were understood in relation to the aims 
and goals of the state. The role of the state is now completely erased in the narrative around symbol use. As republican parties have complained (see Graham and Nash 2006), problems over symbols now appear to be between two groups who simply cannot get along. The question of the legitimacy of the state is elided; the state is removed from being part of the problem or the solution (see McVeigh 2002; Bryan 2006). Responsibility is displaced to the 'two communities'. That symbols are now on the political agenda is a rather new development, one that has formed with the peace process, where divisions between communities were made central and the state imagined itself as a neutral arbitrator between groups. After explaining the problem of symbol use, the Re-Imaging report goes on to note: "Not surprisingly initiatives in relation to these matters have formed part of the new social and political agenda, leading to the idea of making use of artistic expressions in addressing the physical manifestations of sectarianism and racism" (Independent Research Solutions 2009: vii). The governmental attention to disputes over parades must be understood as part of a larger attempt to map the symbolic landscape of Northern Ireland, primarily in the effort to govern relations between groups constituted as problematic.

\section{Thesis}

At present, considering the various interventions in Northern Ireland in such things as flag flying and wall murals, there is a concerted attempt to govern political struggle through the symbolic; that is, to capture and act on what are deemed to be conflicted social relations through managing and administering the use of signs, symbols and symbolic displays. With the parades crisis in the mid-1990s and the advent of the Commission, governing bodies shifted focus towards the meaning of events. New questions were posed: how can the environment in which parades take place be made more conducive to events occurring peacefully? How can local symbolic politics and political relations be discovered and 
managed? How can disputes be understood and solved, not in the divisive terms of 'winners' and 'losers', but in the more palatable democratic terms of 'rights and responsibilities'? More broadly, how can parades come to mean something other than a struggle for power between two groups? While parades were long understood as a symbolic display which provoked animosity between groups, such questions and concerns were not on the agenda when parades were addressed as problems of 'law and order'.

This dissertation argues that the advent of the Parades Commission in 1997 marks a significant shift in governmental approach: rather than attempt to ban or prohibit parades, the Commission was concerned with directing and managing the conduct of individuals and groups. The Commission aimed to govern political struggle through transforming parading practices into an administrable object. While the problem of public order was still central, and certain repressive tactics were still used, the essence of the Commission as a governing body was to promote 'community relations', to incite local dialogue and engagement, and to encourage recognition of 'rights and responsibilities'. The meaning of parading - what such events and their elements signified, the meaning of behaviours, manners, and actions in organizing a parade and while on parade, and the perceptions, attitudes, and feelings aroused - became the terrain of government. The aim of governing bodies shifted to manage 'disorder' by managing and administering how parading was practiced; it was thought that parading could be 'done' in a way to avoid arousing or provoking conflict. Such administration was advanced through a mix of repression and incitement to certain forms of conduct.

I argue that parading was made actionable through investments in two forms which co-existed in tension with each other: 'community relations' and 'human rights'. Assessments of both community relations and human rights were used to justify interventions in local 
symbolic politics and relations. Mediation was the central tactic deployed to foster the desired vision of community relations; that is, to foster self-governing subjects who 'genuinely engaged' in dialogue with each other in order to resolve disputes. However, when self-government failed and it came to making determinations, both community relations and human rights were problematic for the Commission: making parade decision based on community relations proved difficult as the category was vague and difficult to specify; the Commission could not meet the governmental requirements of transparency, objectivity, and consistency in decision-making. When parades were later re-invested in terms of human rights, the rigid legal framework also proved unhelpful to make parade decisions. In order to govern parades, the Parades Commission ultimately required (and deployed) the production of a particular kind of knowledge, one that was tacit, fluid and constantly evolving, based on local politics, perceptions, attitudes, and relations.

\section{Chapter layout}

In chapter one, I elaborate on the theoretical foundations of this work, and the tools and concepts used to analyze the practices and processes of the Parades Commission. I discuss the research contributions of this project and the ways in which it advances the literature on both governmentality and Northern Ireland politics. I also detail my methodological approach.

In chapter two, I trace how parading in Northern Ireland was re-problematized in the mid-1990s. I argue that in the context of increased violence associated with parades, culminating in a crisis in 1996, in conjunction with the development of the wider peace process, parading re-emerged as a political problem, requiring a new governmental solution. Specifically, parade disputes, once specified as a problem of 'public order' to be dealt with by police using pubic order laws, were re-specified primarily as a problem of 'community 
relations' to be governed by a Parades Commission. While some elements of the new regime were already in operation, such as informal local negotiation and haphazard attempts at mediation, the advent of the Parades Commission in 1997 marks a distinct shift in governing rationality.

In chapter three, I discuss the birth of the Parades Commission and outline the heterogeneous assemblage of elements directed at the spaces and politics of parading. I review the establishment of the Commission as a public body, its legal foundation, and early reactions to the Commission, as well as problems with the initial appointment of members. I also review the Commission's administrative procedures and the chapter works to provide an overall sense of how the Commission operated. I argue that through its informationgathering documents, the Commission produced the central object it sought to govern, 'contentious parades'. Such forms worked to invest the grounds of parading by sorting and classifying events in terms of 'contentiousness'. Those deemed 'contentious' were subject to further governing measures, with the first step being to foster mediation between parties in disputes. The final part of the chapter discusses the Commission's Code of Conduct, which was intended to apply to all notified parades. The Code was designed to re-shape how parading was organized and practiced. The analysis illustrates the ways in which governing parades was an attitudinal and behavioural project.

The next three chapters address the two central governing tactics deployed by the Commission: mediation and making determinations. Chapter four deals with mediation as a form of knowledge and tactic of power. I argue that the deployment of mediation brought forth a set of practical knowledges which worked to constitute the space of parading as a governable domain. Mediation knowledges deemed certain modes of relating problematic, while giving authorities tools to foster relations deemed 'healthy' and appropriate for a 
pluralist democratic society. The goal of mediation was to transform relations between groups in conflict, and ultimately, to shape interiorities. The Commission spent considerable effort to find ways to foster 'genuine engagement'. The discussion illustrates that mediation was not easily applied to the Northern Ireland context and governing bodies worked to adapt the framework to account for local symbolic politics and political struggle.

In chapter five, I examine the knowledge production practices that went into making determinations. I examine the specific kinds of information collected and deemed relevant when the Commission first began gathering 'evidence' to make determinations.

Geographical locations were central to how evidence was gathered and I argue that governing parades relied on a particular constitution of space in Northern Ireland. The Commission's work depended on already defined territorial boundaries divided by religious/political grouping, namely, Protestants and Catholics. Further, in considering the factor 'the impact of parades on relationships within the community', the Commission worked to map local political relations where parading took place. Local feelings and 'sensitivities', forms of knowledge ('perceptions'), and relations were made the terrain of government. This chapter also reviews the second part of the Commission's administrative procedures, where information-gathering forms were used to assemble 'evidence' to make determinations. As also touched on in chapter two, I argue that such practices worked to invest the grounds of parading in forms amenable to administration.

In chapter six, I examine how the processes of making and articulating determinations changed over time and illustrate how the field of parading was re-invested in terms of human rights. With the incorporation of the European Convention on Human Rights (ECHR) into UK law on October 2 2000, the Commission adopted a human rights framework to explain and justify its decision-making. Determinations became significantly 
more standardized in format, as the same rights principles were simply repeated from decision to decision. This chapter also illustrates how governing advanced and transformed in relation to the wider field of political struggle. The use of a human rights framework partly arose because of a need for the governing body to protect itself from legal challenges to its decisions; something the Commission anticipated to come from the Orange Order. Finally, I show that the ultimate promise of human rights was not attained; the legal use rights did not function effectively as a technology of subjectification.

In chapter seven, I continue to address the challenges and resistances which have besieged the Parades Commission since its inception. I examine the various governmental reviews of parading and the Commission's operating procedures. There have been five significant reviews to date, spanning from 1999 to 2010, while another review is underway at the time of writing. The reviews exemplify how governing parades was an unstable and fragile project, advanced through processes of political experimentation. The governmental attempt was intimately tied to official politics and the wider political agenda. This chapter also discusses how events not intended to be regulated by the Commission were caught in the regulatory net. Finally, I highlight minor acts of resistance and interactions with the Parades Commission, mainly on the part of parade organizations and bands. I argue that the advent of the Commission produced a new field of struggle, in which the Commission was one actor among others, where each pursued its own interests and agendas. It cannot be said that the Commission has been successful in producing the desired regulatory subjects.

In conclusion, I consider the governmental attempt more broadly and directions for future research. 


\section{Chapter One \\ Governmentality, Investments and Political Experimentation: A Methodological Discussion}

The key foundation for this work is Foucault's insights on modern governmentality and knowledge production, as well as his approach to the study of political problems more generally. With his studies of the history of madness, crime and delinquency, and sexuality, Foucault developed a new approach to interrogate political problems and practices. Rather than begin his interrogation with political structures and institutions, defined problems, and proposed solutions, as much academic work had done, he reversed common analyses to ask how certain practices came be defined as problems in the first place: through what processes are practices problematized so as to emerge as real, and as something to be regulated and controlled? His work reveals madness, as a domain of scientific knowledge, to have emerged through "the establishment of a certain objectivity"; delinquency is revealed as a condition that emerged through the "development of a politics and a government of the self" which he identifies as discipline; and sexuality, thought to be something 'inside' the core of every human, is revealed as a production through the "elaboration of an ethics and a practice in regard to oneself”. Of all three areas Foucault says, “[i]t is basically a matter of different examples in which the three fundamental elements of any experience are implicated: a game of truth, relations of power, and forms of relation to oneself and to others" (Foucault 2003b: 23).

For Foucault, in the modern era, mechanisms of knowledge and power emerge as central for the control of individuals and populations. In Discipline and Punish for example, Foucault illustrates how the examination, along with techniques of notation, writing, and data collection made possible "the constitution of the individual as a describable, analysable object" (1995: 190). Holding each subject under the lens of a whole host of objectifying, 
scientific knowledges, the individual becomes a case to be known, described and documented in detail. In that the knowledge collected on the individual works to control and regulate conduct, to tie the individual to his or her own status or traits according to the normal, the examination is a procedure of both objectification and subjection.

It is in his study of the 'problem of population' that Foucault comes to describes a specific form of power, distinct from sovereignty and discipline, that he called government. Foucault finds that government is no longer about the prince or king maintaining sovereign power, but the end of government is population itself (ensuring its health, welfare, good condition etc.). It is the population that is acted on through techniques that work to shape it towards various ends (2003a: 241). As the object of government shifts to population, it follows that the knowledge of government must be that of all the processes related to population, what we now know as the 'economy'. Both the birth of 'population' as the object and end of government, inseparable from the birth of 'political economy', led to a form of 'governmentality' that characterizes today's modern western societies (2003a: 242). Therefore by the word 'governmentality', Foucault means: "The ensemble formed by the institutions, procedures, analyses, and reflections, the calculations and tactics that allow the exercise of this very specific albeit complex form of power, which has as its target population, as its principle form of knowledge political economy, and as its essential technical means apparatuses of security" (2003a: 244). While Foucault draws a distinction between modes of power, he also stresses that government does not 'replace' sovereignty and discipline. Rather, he suggests "one has a triangle, sovereignty-discipline-government" (2003a: 243).

Foucault's elaboration of a specific political rationality can be regarded as the first study in governmentality. From this work, scholars have adopted his particular approach to 
the study of political power and further elaborated governmentality into a conceptual framework or 'analytic'. Stenson notes that governmentality has emerged as one of the major theoretical and methodological tools for analyzing how populations "are rendered thinkable and measurable for the purposes of government" (1998: 333). Studies in governmentality after Foucault often center on 'problematizations' and the 'programmes of government' which are developed to intervene and regulate them. "Programmes presuppose that the real is programmable, that it is a domain subject to certain determinants, rules, norms and processes that can be acted upon and improved by authorities. They make the objects of government thinkable in such a way that their ills appear susceptible to diagnosis, prescription and cure by calculating and normalizing intervention" (Rose and Miller 1992: 183). A study in governmentality also aims to analyze the means through which government is accomplished, that is, all the tactics, strategies and technologies used, where technologies are thought to be "humble and mundane mechanisms... techniques of notation, computation and calculation; procedures of examination and assessment; the invention of devices such as surveys and presentational forms such as tables..." (Rose and Miller 1992: 183).

Integral to the approach is the identification of governing knowledges. Following Foucault's work, such knowledges play a central role in how governing strategies are developed: "To govern a population one needs to isolate it as a sector of reality, to identify certain characteristics and processes proper to make its features notable, speakable, writable...Government thus depends upon the production, circulation, organization of truths that incarnate what is to be governed, which make it thinkable, calculable..." (Rose 1989: 6). Authorities rely on certain knowledges to develop a conception of what governing programmes are to achieve, what type of subjects are desired, and what technologies will 
elicit the preferred behaviour. At the same time, governing programmes produce certain knowledges or truths (Dean 1999: 18).

Foucault's work then, leads me to start with practices, as the end-points of power, and to interrogate the processes through which objects and events emerge as problems requiring governmental attention. Rather than asking how symbols are deployed in political campaigns or party politics, which assumes their character and significance, Foucault allows me to interrogate how objects and events take shape, how they emerge with particular properties, and come to be thought about and defined in particular ways. He enables consideration of the ways in which power and knowledge work in tandem, such that knowledge enables the flow of power to its end-points and vice-versa, enabling, producing, constituting, subjects, objects, and practices. In addition to Foucault's work, the wider governmentality literature is useful for considering the concrete ways in which governing bodies, such as the British state and the Parades Commission, attempt to specify, know, and calculate parading practices, with concern for the techniques, strategies and tools used to do so. Solutions posed to particular problems might have been otherwise, and as such, solutions, designs, and interventions, signal the specificity of the problem. More generally, no government can intensely administer that of which it is ignorant, and in this respect, governmentality provides the foundation on which this study rests.

In addition to governmentality, a useful supplemental tool to understand the work of government is the concept of 'investment in forms'. Building from Thévenot's initial use of the term (1984), as well as the work of Alain Desrosières (1990), Bruce Curtis has further elaborated on the idea of 'investment' (2000; 2001). In his book, The Politics of Population (2001), Curtis explains that the concept of 'investment' carries three connotations: 1) Investment in the conventional sense of putting economic resources towards a particular 
end. 2) Laying hold or seizing as in the old military meaning, where armies invest castles, diseases invest cities, and statisticians and census makers invest social relations. 3) Investment connotes the practices that surround investiture; that is, the imbuing of social relations with particular attributes (when social relations are 'seized' in this way, such as through census making, aspects of human life etc. are named). The indeterminate world comes to be seen as ordered. Successful statistical investments create 'things which hold together' (Desrosières 1990) - actionable objects such as birth rates, death rates, indices of poverty, movements of population (2001: 31). "The concept emerges out of projects that seek to configure social relations so that these may be known and mastered". Investment is a way of 'gaining purchase' on dimensions of social life. In this account therefore, population “is not an observable object, but a way of organizing social observations" (24). Curtis (2000) provides an excellent example of 'investment in forms' in his work on the 1866 Cholera scare. He argues that the cholera scare led to attempts to "invest the emerging domain of public health in statistical forms" and it was only once produced as such, could the domain of public health be acted on. "Such investments were fundamental to interventions in the name of health, a key site for state-forming initiatives" (Curtis 2000: 35).

Alain Desrosières' (1990) work on 'how to make things which hold together' is also worth noting. Citing the Durkheimian tradition, Desrosières says that 'social facts' can only be treated as things if they are "hardened in one way or another" (citing Thévenot 1984), as are "institutions, laws, religion, and customs" (198). The spirit of this work is to examine the social and scientific practices through which things come to appear as 'real' and to achieve a kind of permanence. Desrosières explains how part of such processes requires the construction of equivalencies - through making social links between individual events, the differences and contingencies between them are eliminated. Classifications and descriptions 
of the social world allow for individual instances to be grouped together, consolidated, such that it becomes possible to speak of something as though it were a coherent object or 'thing'. As Curtis argues, statistical recordings (what Curtis calls 'statistical investments' and what Desrosières calls 'statistical objectifications') are a prime example which allow for the production of birth rates, death rates and other indices which can then be used to govern population.

Drawing on these ideas then, parades must not be understood as observable events. Such is a realist conception which takes for granted what counts as a parade. From my perspective, parades only appear observable due to investments in forms - social observations were organized in some way so that we have come to know what counts as a 'parade'. The concept of investment in forms is useful, for it underscores the work involved in making parading knowable, and so tangible, material, and actionable for the purposes of government. It allows us to think the ways in which categories, classifications, scales, and other forms of measurement and information gathering tools, are central to the government of parades.

\section{Research contributions}

This project is novel in three respects: One, it deals with governing symbols, symbolic displays, and symbolic politics, a topic not often found in governmentality studies; two, it deals with governmentality in a context of conflict, contestation, and political struggle; and three, it attends to process and governing as political experimentation. As widely as governmentality has been adopted as an analytical approach, there are an equal number of critics. This project works towards addressing some of these criticisms and advancing the field of study, partly through the topic of study, and partly, as with the concept of investment, through adding a few key ideas to the analytic toolkit. 
It is best at this juncture to explain my use of the symbolic. There is or can be a symbolic dimension to all practices and to all governing endeavors. The symbolic is ubiquitous and ambiguous. It is difficult to define, and near impossible to classify, categorize, or locate where it 'is' at any given moment. As American cultural theorist Jeffery C.

Alexander notes, in contemporary societies, "all actions are 'symbolic' to some degree" and in social science he says, "it is best to convert such dichotomous either/or questions into matters of variation" (2004: 566).

I wish to differentiate between signs and symbols in the act and problematization of parading and other sorts of practices, like habits or routines, which may also have symbolic elements. Consider, for instance, hand-washing. Individuals may wash their hands in public restrooms, not only for habitual and hygienic reasons, but for symbolic reasons; that is, for how it appears to others in the restroom at the same time, in that washing one's hands may symbolically connote a clean person with good habits. However, hand-washing is not primarily understood as a ritual and symbolic activity. With the SARS outbreak in 2002-2003, hand-washing did not become a governmental problem because of what it signifies; rather, it was problematized as a matter of public health. Effective hand-washing was deemed important in order to prevent the spread of disease.

While we live in a symbolically coded and narrated world, not all signs and symbols are equally important or remarkable. In Northern Ireland, parts of the symbolic domain have become politically problematic. The case of parading is about the government of contested, heated, politically charged mobilizations of sign, symbols and rituals. With the advent of the 1997 North Report and the establishment of the Parades Commission, the target of government came to include parading as a symbolic practice in all its aspects - from how it was organized, the manner and mode of communication between parties, to the symbolic 
meaning of the route taken. The Parades Commission attempted to get hold of elements of parading that caused 'tension', to 'discover' where such tension existed, and how to deal with it. The same may be said for the attempt to get hold of that which was 'sensitive', 'contentious', 'provocative' and 'offensive'. Governing parades required 'discovering' perceptions, attitudes, and sentiments. In short, it required rendering visible the symbolic politics and power relations around parading - that which was not a central concern when parades were dealt with as more basic problems of public order.

The elusive, emergent, and fluid properties of parades, as symbolic displays, present difficulties for the more commonly known means and ways of modern governmentality. Symbolic meanings are more ambiguous, contingent, and contextualized, than most other objects of government, such as those that can be more easily rendered knowable, calculable and predictable through expert knowledge, statistical data, or social and scientific information. ${ }^{5}$ Signs and symbols and their meanings problematize government in that they are not simply inanimate objects that can only be mobilized, shifted, or strategically moved, yet, they are not actions or practices either that can be more explicitly and tangibly deliberated on and controlled.

To date, the governmentality literature lacks serious consideration of the relationship between the symbolic realm and practices of government. ${ }^{6}$ Foucault's move away from the

\footnotetext{
${ }^{5}$ Here, I am thinking of governmental objects such as alcohol use or driving, which are related to comportment or actions.

${ }^{6}$ While not much scholarly work explores the intersection of governmentality and the symbolic, there is a literature on the government of culture (see Bratich et al. 2003). Scholars have attempted to merge cultural studies with a Foucauldian theoretical approach. Tony Bennett $(1992 ; 1995)$ in particular has pursued this line of inquiry, taking up governmentality studies specifically. In his genealogy of museums (1995), Bennett argues that museums ought not to be seen as institutions of enlightenment, but as a technology of power where 'culture' is used to develop and advance the social and civic behaviour of particular groups. For Bennett, culture is not about linguistics or signification, but is a set of technical practices for the government of conduct. Such work is related in some general ways to my endeavors here, mainly in that, more broadly, my case speaks to governing
} 
model of sovereignty worked to displace consideration for ritual and symbol as a political force, a displacement that continues in later governmentality works, leading to the neglect of an important component of political power. With the rise of discipline, expert, scientific, statistical, and norm-based knowledges emerge as central to the production of modern individuals and identities, and it is these knowledges that are reflected in studies of governmentality. This focus is to the neglect of considering signification and signifying practices, as noted by Cousins and Hussain (1986), or emotionally-driven knowledges as noted by Garland (1997: 202). Singer and Weir (2006) are among the first fully to recognize and treat this deficiency. They write: "The consequent focus on governance as a form of expertise emphasizes the instrumental, strategic dimensions of modern knowledge to the exclusion of the symbolic, or at least subordinates the symbolic to the instrumental/strategic. The result is a marked blindness to the symbolic organization of modern power and knowledge" (2007: 450).

The case of parading in Northern Ireland and the work of the Commission is pertinent to exploring not only the ways in which a symbolic display is at once the object of government, that is, something to be specified and known, but at the same time, to illustrate, as Singer and Weir (2006) suggest, how techniques of governing work through symbolic means, drawing on tacit knowledges, collective beliefs, and symbolic representations. For instance, in using coded language to make decisions, with words such as 'contentious', 'offensive' and 'sensitive', the Commission draws on tacit understandings, and their use works to set up a specific kind of problem requiring intervention. Such knowledges play a

social relations through a particular cultural expression. However, I still locate my research in a different field. I am using a governmentality lens to understand something about how the attempt is made to render a symbolic display practical, technical and actionable through particular governmental techniques. Or put differently, I am examining how, in the attempt to govern struggle, a symbolic practice and ritual display is made into an administrable object and the challenges therein. 
large role in how and where the Commission decides to regulate or intervene. Attending to the engagement between governmentality and the symbolic requires further attention in the Foucauldian-governmentality literature.

Rarely has a governmentality approach been taken up in studies of Northern Ireland, or taken to conflicted societies more generally. ${ }^{7}$ With the advent of the peace process in Northern Ireland and the decreasing preoccupation with controlling outright violence, the logic of power, the means and ends of its exercise, merit further analysis. In one of the only examples to my knowledge, Andrew Finlay (2010) offers a basic governmentality analysis of consociational regimes in his recent book Governing Ethnic Conflict. The book offers some interesting insights on 'technologies of peace'. His main argument is that by taking a governmentality perspective, it emerges that:

...the problem with consociational peace agreements is not simply or primarily that they recognise and institutionalise particular ethnicities, but that they make ethnicity itself normative and in doing so close down the space for other ways of being, other ways of being political, other forms of political conflict... [T] he issue is not so much the differences that always exist even within the most apparently closed groups and situations, but the differences, contradictions, and ambiguities that exist within individual subjects. (10)

Findlay's insights on consociationalism speaks to an audience unfamiliar with critical theory, and this makes sense given the lack of such theoretical endeavors in much of the literature on Northern Ireland politics. The reification of identity is particularly common, as I later note when reviewing the secondary literature on symbols. I go beyond Findlay's work by eschewing identity as an organizing category as a basic premise of my theoretical approach, and by undertaking an empirical study of governing practices in Northern Ireland.

Also, in the governmentality literature there is a lack of attention to the way official politics and political contestation are implicated in processes of government (Walters 2012:

${ }^{7}$ For notable exceptions see: Merlingen and Ostrauskaite (2005) on peacekeeping and policing in Bosnia; Tikly (2003) and Christie (2006) on education policy in post-apartheid South Africa. 
78; Barry 2002: 270; Hindess 2004). Often politics is too quickly judged to be the 'obvious' expression of power, as scholars prefer to focus on power in more mundane and less visible manifestations. In the case of parading in Northern Ireland, the dynamic between official and local politics plays a large role in the processes of government and in the work of the Commission.

On a related point, much governmentality work isolates the ways in which governing bodies constitute subjects or objects, ${ }^{8}$ to the neglect of other forces, social and material, that may push or pull, alter, or otherwise interact/engage with this attempt. In much work, the way political rationalities become embodied in governing projects is thought to produce the ‘truth' according to which we are governed and govern ourselves (Dean 1999: 18). The case of parading illustrates that the impact of governing projects cannot be taken for granted or given too much weight. The Parades Commission does not establish itself in a vacuum; rather, it seeks to instantiate itself in a context of already on-going struggles between historically constituted groups, each with their own agendas. As Stenson (1998: 348) argues, within localities there exist already formed groups, subjectivities, and networks of governance. The struggles of the Parades Commission highlights how those groups it aims to govern also impact, shape, and challenge governing processes. Related to the next point, the context of conflict and attention to power struggles means paying attention to process and understanding power as fluid and dynamic, rather than monolithic.

Studies in governmentality have been critiqued for producing government as coherent and rational, where projects are implemented as envisioned, or have smoothly produced regulated subjects. By placing the vision of formal ruling bodies, that is, their idea of how the social world looks and is to look, at the center, O’Malley, Weir and Shearing

8 I do not mean to say that isolating the work of governing bodies is not a legitimate question or a sufficient question in other cases. 
(1997) argue that this focus has led to a neglect of studying social relations and all the 'messy actualities' of government. This has meant a lack of attention to social contestation and variation, and consequently, the tendency to reify political rationalities as ideal types. The result is a rather systematic and systematized account of governing practices, rationalities and technologies. In practice, as chapter six in particular aims to show, governing often advances through political experimentation and processes of implementation-failure-reimplementation, or what Walters (2012: 74) calls 'patch work'. Attending to patch work means to attend to the ways in which authorities must continuously improvise and reformulate procedures in the attempt to make the governing project work as intended or otherwise (Walters 2012: 75). Rose and Miller (1992) also note that governing is never complete.

In order to better conceptualize the idea of political experimentation, I draw on Callon's (1998) concepts of framing and overflowing. The concepts help think about the difficulties imposing a 'frame' on parading, such that 'leaks' are the norm. Wherever the frame fails, meaning its boundaries are exceeded or transgressed, there are 'overflows' which must be addressed and contained for the governing project to advance. Attending to such processes, and the ways in which governing advances through a dialogical relationship between governors and the political field, merits further attention in the literature.

Finally, O’Malley, Weir and Shearing write that "the understanding of what constitutes government has been recast in more restricted ways over the past generation" (1997: 509). The tendency to equate 'rationalities of government' with the 'art of governing', where rationalities are defined as 'ways of thinking', relegates studies to the domain of 'thought', or as they say "the theoretical object is constrained to describing mentalities of rulers, a much more restricted inquiry than the institutions, procedures and practices of 
government found in Foucault's earlier work" (510). Foucault used the concept of dispositif, or 'apparatus' in English, to, as Walters notes, “emphasize that the analysis of power relations cannot be confined to the study of discourses, but needs to explore the intersection of discourses with various heterogeneous elements, such as laws, architecture and administrative procedures" (2012: 76-77). By dispositif Foucault meant: "a thoroughly heterogeneous ensemble consisting of discourses, institutions, architectural forms, regulatory decisions, laws, administrative measures, scientific statements, philosophical, moral and philanthropic propositions - in short, the said as much as the unsaid". An apparatus consists in "the system of relations that can be established between these elements", which are discursive and non-discursive (Foucault 1980: 194).

For Foucault, an apparatus is a formation which responds to an urgent need at a precise historical moment, and it has a primary strategic function (1980: 195). An apparatus constitutes the objects and subjects it seeks to govern (to subject) such that these appear to have an inherent existence and to be in need of administration. Foucault's classic examples of this are in the History of Sexuality (1990) with the production of 'sex' and in Discipline and Punish (1995) with the production of 'the delinquent'. With this productive capacity, an apparatus or dispositif is the nexus of power/knowledge relations.

One way to think of the Parades Commission and the ensemble of elements directed at parading is as an apparatus. However, I follow Walters' suggestion to make a distinction between an apparatus and an assemblage. Walters follows Rabinow (2003) in making a distinction between the two terms. An apparatus is something that is made durable and transposable, meaning it is "a particular configuration of elements that has proved itself to be relatively stable and adaptable to a variety of social purposes in a variety of settings across time and space" (Walters 2012: 77). Walters notes that insurance, discipline and confession 
are examples of an apparatus. An assemblage, on the other hand, is more transient and changing; it is less instantiated and it may fail as a programme of government. "Assemblages either crystallize into apparatuses, or they fragment and disappear" (77). Walters argues that making a distinction between the two concepts is important in terms of allowing for complexity, fluidity, and failure in the governing process. Given that I am studying the present which makes it hard to identify an apparatus, and given the difficulties and instability of the Commission over the course of its existence, I consider the ensemble of regulations, administrative procedures, laws, and discourses directed at parading as a space of assemblage.

\section{Secondary literature on parades in Northern Ireland}

While in-depth studies of parades in Northern Ireland are relatively few in number, two authors, Dominic Bryan and Neil Jarman, have made well-known interventions in the area, more generally from an anthropological, ethnographic and historical perspective. ${ }^{9}$ Bryan's book, Orange Parades: The Politics of Ritual and Control (2000), usefully traces the history of Orange marches and their relation to the state. He argues that the rise of the Troubles left Protestants feeling threatened. Paramilitary involvement in parades increased and parading became more sectarian and disorderly. He argues the $12^{\text {th }}$ of July parades, known as 'the Twelfth', changed 'from being an expression of the state of Northern Ireland and its unionist government to an event utilised by an increasingly divided and disillusioned unionist community for its own 'defence”' (Bryan 2000: 92). Jarman’s book, Material Conflicts: Parades and Visual Displays in Northern Ireland (1997), centers on parades as acts of commemoration, which work to construct collective memories, and are a means of 'displaying faith'. His book

\footnotetext{
${ }^{9}$ See also the edited collection by T.G. Fraser (2000), and Bell (1990) which is an ethnographic study of two marching bands. Much has been written on the Orange Order and the Twelfth, for instance see Kaufmann (2009), and Rider and Kearney (2001).
} 
traces the history of parading since 1690 , locating its changing significance in relation to the wider political climate.

Aside from these main works, both Bryan and Jarman have published numerous articles touching upon issues such as, parades and the politics of 'tradition' (Bryan 2006a), issues around mediation and stewarding (Bryan 2006b), material cultural and identity (Jarman 1998), legal measures towards parades (1999), and band culture (2000). In one article, Jarman (2003) documents the disputes over parades, the arguments on 'both sides', and the responses to the Parades Commission. As part of his work on material culture, he often speaks to the symbolism of banners, flags and emblems (which tend to have historical significance). Bryan has written on the politics of symbolism, with a new attention to flags (with McIntosh 2007).

Sean Farrell (2000) has written on parading political culture in Ulster between 17841886, documenting the historical significance of parades. More currently, Michael Hamilton has published a series of works on parading disputes (some non-academic, NGO publications), outlining the legal issues around public assemblies (2005a), the right to march (2001), and parade-related protests (2005b). Hamilton and Bryan (2006) have also written together on the Parades Commission addressing the ways in which the body works as a dispute resolution mechanism, drawing on Habermasian theories of communicative action. Bryan, Jarman, and Hamilton were active in the development of the Parades Commission and played a significant role in the advancement of government, often acting as expert advisors. As such, much of their work figures prominently in this dissertation.

In these and most other works that address the symbolic landscape in Northern Ireland, the notion that symbols and rituals are integral to identity politics is widespread. Jarman writes that for loyalists "parading is a means of displaying faith and pride in one's 
culture, and exercising the right to parade is also a means of confirming that Ulster is British” (1997: 124). Generally, symbols are thought to express and reflect political, cultural, and social identity. Of Northern Ireland, Brown and MacGinty write: "Attitudes towards symbols can legitimately be regarded as a lens though which to view identity, particularly in the context of a deeply divided society. Symbols can be the public manifestation of a group identity or aspirations, and strength of attachments to symbols may reflect the strength of identity bonds" (2003: 84). Identity in these contexts tends to be reified as inherent and static, thought to exist independently and prior to the practices through which it is produced. From my perspective, signs, symbols, and symbolic displays cannot in and of themselves express or reflect identity. They cannot, on their own, reflect or express anything. As material entities, they can move or be moved, but any signification they appear to reflect is a performative production. ${ }^{10}$

While the anthropological, historical, and legal approaches to parades are well covered, there is space in the literature for a sociological analysis. In particular, there is much space for approaching parades through a more rigorous, critical, theoretical lens. The general focus in works on Northern Ireland tends to be on the pragmatic practices of government; on party politics. Questions of governance, policy and public administration are usually central. My project differs from these works in taking a post-structuralist rather than realist

\footnotetext{
10 There is a significant literature on parading, rituals and festivals in Canada and the United States, much from a historical perspective. The historical literature provides a richly detailed account of various parades, festivals, and public celebrations, mainly in the 19th century. In many works, parades are argued to play a role in nation-building, nationalism, political culture, or in memory-making. For studies in the U.S, see Newman (1997) and Davis (1986). For parading in Canada, see Gordon (2001), Radforth (2004), Goheen (1993), and Heron and Penfold (1996). While the perspective on parades and rituals varies, most common is the understanding of parades and public rituals as 'expressions' or 'displays' of identity (or, if not explicitly identity, then some other form of representation). Much of the literature centers on identity politics. As such, it is beyond my purposes here to present an extensive review of these works. I am approaching parading from a different theoretical perspective.
} 
or realist-constructivist view of reality, and by centering the production of the symbolic as a domain of knowledge. As such it is not about studying symbolic content, it is not about symbols or parades as expressions of reality or identity; nor is it about symbols 'and the content they express' being strategically used by political parties or governing bodies. Rather, it takes such common approaches to symbols in the social sciences as something that needs to be analysed, rather than assumed. As well, to date, aside from Michael Hamilton's (unpublished) PhD thesis in Law which centers on the legal workings of the Commission, there is no major case study of the Parades Commission, nor work addressing it from a Foucauldian-governmentality perspective.

\section{Central empirical questions}

My central empirical questions may be divided into two general categories. One, how was parading in Northern Ireland constituted as an object of government? Through what strategies, tactics, administrative procedures, and discourses was parading, and the individuals and groups involved, acted on or attempted to be governed? Two, towards what ends and with what consequences? What challenges or resistances did the Parades Commission face? In what ways did the attempt to govern a symbolic display challenge the processes and practices of government? In what ways did the lack of political consensus and history of conflict shape the governing project? How was governing a process of political experimentation?

\section{Methods}

In order to give an account of the government of parades, I analyzed diverse governing texts. Documents included those produced by the Parades Commission, state and non-state bodies, such as NGOs, community groups, and quasi-academic productions. I focused on texts produced largely since the early 1990s when parade disputes began to receive greater 
academic and political attention. The documents include relevant Acts (laws), government and non-government reports and reviews on parades and the Parades Commission, conferences organized by various bodies, as well as local news articles. The topics range from dealing with mediation measures to the application of human rights principles, among other issues.

The core of my material centers on documents produced by the Parades Commission from its inception to present day, including all Annual Reports, statutory documents, conference proceedings, and determinations made from 1998 to the present. From a governmentality perspective, information-gathering procedures are central to the production of an object of government. Therefore, my work focused on the processes and practices of knowledge production engaged in by the Commission. To that end, I studied templates of the Commission's administrative forms used to collect information from parade and protest organizers, the police, Authorised Officers, and monitors. Such documents provide an account of how parades were invested in a standardized form amenable to practical administration.

When reading documents and analyzing the procedures of the Commission, I focused on both the discourses and practices deployed in the government of parades. From a governmentality perspective, there is a link between the interpretation of problems and the practical measures used to address them. Discourses embody particular conceptions of the world, conceptions which may be different at other points in time and in other contexts. It is based on such conceptions that governing advances. The deployment of discourses is also central to the conduct of conduct. In this case, the discourses of 'community relations' and 'human rights' worked to shape understandings of the parading problem and justified interventions in their name. 
In governing texts, I looked for evidence of how parades were administered through practical strategies and tactics. Such tactics formed a mix of incitements to certain modes of conduct, and when the latter failed, repressive disciplinary action through making parade restrictions. I noted incitements in forms such as what the Commission 'hopes' and 'expects' of those involved in parade disputes. In examining the Commission's governing procedures as a whole, I looked at the work that went into fostering particular kinds of subjects and flagged statements, standards, and principles which outlined certain modes of behaviour and ways of relating. I also looked at the work that went into knowing and calculating 'contentious parades' in order to make determinations, such as the Commission's 'evidencegathering' procedures and the manner in which it justified limiting freedoms.

Finally, I also sought to highlight events that revealed the ways in which governing parades was a process of political experimentation and 'patch work' (Walters 2012). Such events included interactions between the Commission and other groups, such as the Orange Order and the Protestant/unionist/loyalist community, as well as residents groups and the Catholic/nationalist/republican community, including the political parties associated with each. I also looked for points of contention in the Commission's procedures, challenges and resistances, and problems which continuously plagued the body. I considered how such struggles shaped governing practices.

To supplement my textual analysis, I conducted participant-observation and field work in Northern Ireland over the course of three summers. I travelled to Belfast, Northern Ireland, in July 2008, 2009, and 2011, with each visit being between two and five weeks. Over the course of the three trips: I visited the Parades Commission offices, had informal discussions with members of the secretariat (the administrative body which runs the day to day proceedings), collected documents, had several informal discussions with an Authorised 
Officer, and shadowed an $\mathrm{AO}$ while attending several contentious parades, including those on July 12. I attended a PC determination meeting, attended several PC debriefing meetings post-parades, met with a police officer who supplied several pertinent administrative forms, and met with scholars Dominic Bryan and Michael Hamilton, among others things. My visits to Northern Ireland allowed for a much greater understanding of how parades are governed in practice. It also added significant nuance to governing texts. My visits, however, could not replace living and being in Northern Ireland full time, and therefore I acknowledge a lack of nuance still exists. My time in Belfast gave me at least one central insight: if there is any place where things are not what they seem, it is Northern Ireland; there is always a back story to events. Given that I had to rely mainly on texts for my analysis, and while many textual forms captured complexities (e.g. newspapers, blogs), the above must be born in mind when reading this dissertation. 


\section{Chapter Two \\ The Government of Parades in Northern Ireland: From Policing 'Public Order' to Governing 'Community Relations'}

\section{Introduction}

In the first section of this chapter, I discuss how parade disputes in Northern Ireland were dealt with prior to the advent of the Parades Commission in 1997. Parade disputes were principally addressed through public order laws which were enforced by the police as disorder or potential disorder arose. I review the history of parade-related legal controls and discuss in particular the legislation addressing parades prior to the Parades Commission: the 1987 Public Order (NI) Order. This approach towards parade disputes, which may be called a 'law and order' approach, bears the hallmarks of Foucault's concept of sovereign power; that is, a form of power which works through prohibitions on conduct and limiting freedoms.

In the second section of this chapter, I discuss the events leading to the reproblematization of parades. Parade disputes and the procedures for handling them came under public and governmental scrutiny when, in the mid-1990s, the scale and number of disagreements escalated significantly. In the context of the peace process underway at the time, the 'law and order' approach was deemed problematic and new questions about how to resolve parade disputes were posed by governmental and non-governmental actors and groups. After the violence associated with a particular parade, the Drumcree church parade in Portadown in July 1996, the government launched the Independent Review of Parades and Marches in order to 'make recommendations for the better management of future controversial parades'. This report, known as 'the North Report,' is the central mechanism through which parades were re-constituted as a political problem, requiring a new governing solution. 
In the final section of this chapter, I discuss the process through which parades began to be governmentalized. By way of an analysis of the documents produced on the 'parades issue' in 1995 and including the North Report in early 1997, I argue that restricting parades through public order laws significantly gave way to governing parades by a 'Parades Commission'. By the time the Independent Review was published in early 1997, parades were transformed in the governing vision: they were now understood as important expressions of 'identity', and conflict over such displays was deemed representative of misunderstanding, distrust, fear, and hostility between two groups - Catholics/nationalists and Protestants/unionists - the same societal factionalism that has plagued Northern Ireland since its birth. Effectively, how parades took place (peacefully or with conflict) emerged as $a$ measure or barometer of societal health in a divided society. Once constituted as such, parading was figured as an area requiring governmental intervention; it was now a domain to be known and administered in ways that promoted a particular vision of societal relations. Parades were now much more than problems of public order to be policed. ${ }^{11}$

Hence, the North Report suggested that the regulation of parades be transferred from the police to a new independent body, to be called 'The Parades Commission', whose main tasks were to encourage, foster, and promote an environment in which peaceful parading might take place. Only in the event that a 'local accommodation' could not be reached was the Commission to make a legally-binding determination regarding how a

\footnotetext{
11 There is a case here for taking up the literature on anti-policy, state racism and anti-racism (Walters 2008; Lentin 2004; Goldberg 2001) in order to develop the broader state project in which the policy towards parades is situated. By anti-policy, Walters refers to "the ubiquity of discourses, measures and policies whose stated objective is to combat or prevent bad things" (2008: 267). Lentin's (2004) work is also useful. She argues that the discourse of anti-racism re-positions the state as a neutral arbitrator between groups and as the protector of rights and freedoms, effectively rendering the state's role in racism invisible. Such a line of inquiry, while fruitful, would require a more in-depth analysis of the peace process, its discourses and subsequent policy projects than is possible here.
} 
disputed parade could proceed. This movement marked a major shift in policy towards parades and embodied a new governing logic.

Before turning to the legal control of parades, I open the chapter with a brief discussion of Foucault's concepts of sovereignty and government.

\section{Foucault's concepts of sovereignty and government}

Foucault does not conceive of 'government' in the usual sense of the term; that is, to refer to an administrative bureaucracy controlling a particular territory. Rather, for Foucault 'government' designates a specific form of power that he argues began to emerge in the sixteenth century and which he saw as characteristic of modern western societies. In his 1977-1978 course lectures at the Collège de France, Foucault developed his idea of government in contrast to the exercise of sovereign power. This distinction serves as a useful conceptual schema with which to analysis the shifting logic, means, and aims of power exercised towards the field of parading in Northern Ireland.

While a sovereign mode of power imposes itself as a prohibitive force on juridical subjects, that is, subjects constituted in and through law, government involves persuading or enjoining 'free' subjects to act in ways aligned with the aims of another or others. Subjects are conceived of as 'free' in their ability to chose from a variety of possible actions and are potentially resistant. Government is about the deployment of strategies and tactics, rather than the imposition of laws. Again, while sovereignty works through a central ruler, government is thought to be de-centered, working through diverse authorities, in multiple domains. While a sovereign rules with only its own interests in mind (maintaining its territory and wealth), the end of government is population itself (ensuring its health, welfare, and good condition). Population is acted on through techniques that work to shape it towards various ends (Foucault 2003a: 241). As Foucault quotes from one of the earliest texts to 
speak of 'governing', Guillaume de la Perrière's Mirrior Politique of 1576, "government is the right disposition of things, arranged so as to lead to a convenient end" (2003a: 234). Finally, unlike the imposition of sovereign force, the exercise of government depends on knowledge of that which is to be governed. Knowledge is central to develop a conception of what governing programmes are to achieve, what type of subjects are desired, and what tactics will elicit the preferred behaviour.

In sum, while sovereign power works through force, violence, and prohibition, government works by inciting and fostering life. The strategies and tactics of government work by shaping ways of thinking and acting, and by cultivating subjects capable of carrying out governmental aims. This may involve enticing individuals and groups to behave in a certain manner. In this way, everyday life is administered or directed according to a particular vision, rather than solely controlled by laws and force. Drawing on Callon's (1998) concept, to govern is to 'frame' some aspect of social life; to invest it, to give it meaning, and to attempt to manage it.

More simply, Foucault states that power is a question of 'government' which designates "the way in which the conduct of individuals or groups might be directed...". He goes on to say, " $t \mathrm{t}]$ he exercise of power is a 'conduct of conducts' and a management of possibilities". It may be said then, that more generally Foucault defined government as the 'conduct of conduct'. "To govern in this sense is to structure the field of action of others" in a "more or less considered and calculated" manner (Foucault 2003c: 138). Or as governmentality scholar Mitchell Dean states, government "involves some sort of attempt to deliberate on and to direct human conduct" where "human conduct is conceived as something that can be regulated, controlled, shaped and turned to specific ends" (Dean 1999: 11). 


\section{The legal control of parades}

Historically, parades in Ireland and Northern Ireland have been associated with violent clashes between Protestants and Catholics. The relationship between loyal parades, the police and state has ebbed and flowed along with the political context. Writing on the Orange Order in 1880-86 Ireland, Loughlin states: "At no point in time from the establishment of the Orange Order, following a sectarian riot in County Armagh in 1795, was the relationship between [the Order] and British administrations congenial...Orangeism was only accepted out of necessity. When the threat posed by the United Irishmen was eliminated the alliance quickly ended". Essentially, when "Irish nationalism threatened the Union" the government's approach was “reluctant alliance followed by rapid disengagement" (Loughlin 2000: 27). Orange parades and demonstrations were seen by the state as a source of disorder and disruption and were strategically regulated.

Similarly, in Northern Ireland, unionist displays were once closely associated with the state and protected; however, with the changing political context from the late 1960s onwards, by the 1990 s, policing parades centered more on preventing disorder, regardless of where it was deemed to come from - Protestant marchers or Catholic protestors. In either case, whether Protestant parades were protected or restricted, parade-related conflicts were thought about and addressed as a matter of public order to be controlled primarily through the use of legal restrictions. Disturbances were dealt with by the police during the event or as the potential for disorder arose. Following Foucault's conceptual schema, this may be considered as a sovereign mode of power where power works through repression, prohibition and restriction on freedoms.

Before Public Order laws came into effect, there were two other pieces of legislation aimed at controlling parade-related riots and violence. The Party Procession Act of 1832 
made all parades in Ireland illegal. The Act was proposed by Edward Stanley, then Chief Secretary for Ireland, and its aim was summarized in the House of Commons debate on June 14 1832:

The object of his Bill was not to fetter the manifestation of political opinion in any way whatever. His Bill was directed against party processions connected with religious subjects, and calculated to maintain and prolong religious animosities, which moved with banners exciting angry feelings, and which were not unfrequently armed, ready to meet the conflicts they provoked. (Hansard, vol 13 cc 717)

As noted in the introduction to this thesis, the legal control of parades in 1832 was about controlling processions 'calculated to maintain and prolong religious animosities'. Similarly, on February 8 1850, Sir W. Somerville, Chief Secretary for Ireland from 1847 to 1852, stated: “These party processions had caused loss of life and destruction of property, but not that alone; for they had tended to keep alive feelings of animosity and ill-will among the inhabitants of the same district, and thus retarded the coming of prosperity" (Hansard, vol 108 cc 611-3). The Party Procession Act was allowed to expire in June 1845, but it was reenacted in 1850 with an amendment to allow for the imprisonment of offenders (Farrell 2000).

In the $19^{\text {th }}$ century then, parade-related disorder was dealt with through legal measures, yet, governmental figures at the time understood that the violence created a larger problem related to political conflict - that of perpetuating 'ill-will' between groups living in the same geographical space. As will later be seen, Somerville's statement in 1850 sounds very similar to claims made in the mid-1990s about the impact of parade-related violence on 'community relations'. Farrell says that, in practice, the law of 1850 was rather unsuccessful as "hard-line plebeian loyalists kept the marching tradition alive despite the legal consequences" (2000: 157). The Act was eventually repealed in 1872 after Orangeman William Johnston led the fight for the 'right to walk' (see also Jarman and Bryan 1998). 
The second pertinent piece of legislation was the Civil Authorities (Special Powers) Act (Northern Ireland) of 1922. This Act was the first means of legally controlling parades in the British province of Northern Ireland after partition in 1921 (Hadden and Donnelly 1997). It was a sweeping piece of emergency legislation intended to deal with the sectarian conflict; that is, to deal with any threat to the stability of the British state. It allowed police to prohibit or restrict any meeting, procession or assembly deemed potentially to breech law and order. In the period of time from partition in 1921 to the start of the Troubles in the late 1960s/ early 1970s, the Protestant marching organization, the Orange Order, and the newly formed unionist state were closely associated. Many politicians and police officers during this time period were also Orangemen. Bryan argues that Orange parades on July $12^{\text {th }}$ (or 'the Twelfth'), became 'rituals of state' (Bryan 2000: 60). In practice, the Special Powers Act was used to ban such republican political expressions as flying the Tricolour, as well as all manner of meetings and parades, whilst generally allowing loyalist and unionist displays (Donohue 1998; Bryan 2000; Jarman 1999: 1417).

Public Order Acts

The Public Order Act eventually replaced the 1922 Special Powers Act as the primary legal measure to deal with disputed parades in Northern Ireland. The Public Order Act was in effect in England and Wales from 1936. The British government extended the Act to Northern Ireland in 1951 in order to maintain similar laws for all of Britain (Hadden and Donnelly 1997: 19). The Act granted the police powers to reroute or impose conditions on any procession thought potentially to cause serious public disorder. If such conditions were deemed insufficient, the Home Secretary was granted powers to ban all marches in a specific area for up to three months. The Act also made wearing military uniforms, as well as threatening, abusive or insulting words or behaviour a criminal offence. 
While the new laws replaced the emergency legislation in terms of dealing with parades, in practice, the approach was the same. Bryan says that the Public Order Act "effectively allowed for the suppression of nationalist parades, normalizing what had been the position under the Special Powers Act” (2000: 69). In line with this approach, the government also introduced the Flags and Emblems Act in 1954, which "effectively protected the Union flag wherever it flew in Northern Ireland and allowed for the removal of the Irish Tricolour if the RUC felt good public order required such actions” (Bryan 2000: 69-70).

While the Public Order Act was extended from the rest of Britain to Northern Ireland, it was done so with an explicit addition: a requirement that 48-hours notice be given to the police for all processions, with the exception of those parades 'customarily beld along a particular route' (Hadden and Donnelly 1997: 19; Bryan 2000: 61; Jarman and Bryan 1998). The notion of a 'traditional parade' then, has a historical basis in law and practice. Jarman and Bryan write that "this effectively exempted loyal orders from giving notification" and in doing so "it instituted within law the inequalities of power which had allowed a continuity for many Protestant/unionist 'traditions' which had expanded whilst Catholic/nationalist 'traditions' had been restricted" (1998: np).

The rise of civil rights marches and demonstrations along with counter-marches in the 1960s led the government to amend the Public Order Act (NI) in 1970 and again in 1971. In 1970, the period of notice was increased to 3 days and it was made an offence to attempt to prevent a lawful procession or to participate in an unlawful procession. Again, it was stated that police should consider 'the desirability of not interfering with a public procession customarily held along a particular route' (s. 2(1) cited in Hadden and Donnelly 1997: 20). In 1971, notice was extended to 5 days and the factors the police should consider 
when imposing restrictions, rerouting, or banning parades were now to include 'undue hardship to persons working or carrying on business in the area' and 'undue demands on the police or military forces' (s. 2(1) cited in Hadden and Donnelly 1997, 20).

The Public Order Act 1971 was re-drafted as the Public Order (NI) Order 1981 following public order-related events in Britain (Hadden and Donnelly 1997: 22). ${ }^{12}$ The redrafted Order, however, no longer exempted 'customary' or 'traditional' parades from the obligation to give notification. All parade organizers were now required to give notice to the police of their intent to march. ${ }^{13}$

The final and most recent law in effect to date is the Public Order (Northern Ireland) Order 1987. The 1987 Order is significant for my purposes because it was the measure in place to control parades prior to the Parades Commission and is the basis on which policing parades in the mid-1990s was re-problematized. The Order was introduced to maintain parity with Britain when a new Public Order Act was drafted in 1986. While the two versions are similar, in the Northern Ireland version, the Secretary of State has extended powers to override police decisions and to impose a ban on parades at his or her discretion. The notification period was extended to 7 days and the factors the police are to consider when deciding to re-route, impose conditions, or ban a parade were further expanded. They now include:

\footnotetext{
12 Changes to the law were made following National Front marches and violent picketing related to labour unrest (Hadden and Donnelly 1997: 22).

${ }^{13}$ Other sources state this change happened in 1987 and I cannot find much evidence of a 1981 Public Order (NI) Order. However, I follow the work of Hadden and Donnelly (1997) as it is the only work that reviews the history of public order laws in Northern Ireland in significant depth. The Public Order (Northern Ireland) Order 1987 continued not to recognize 'traditional' or 'customary' parades, which did not go unnoticed by unionists (see the 1987 leaflet published by Joint Group of Unionist MPs, Public Order Order: Equality Under the Law?). Unionists saw the lack of recognition for 'customary' parades as a result of the 1985 Anglo-Irish Agreement and the influence of the Irish government. Hadden and Donnelly (1997: 23) make the point that the exemption for traditional marches happened in 1981, before the signing of the Agreement.
} 
i) serious public disorder

ii) serious damage to property

iii) serious disruption to the life of the community

iv) parading for purposes of intimidation

v) and if the event would place undue demands on police resources

(Hadden and Donnelly 1997: 22)

Notification to the police required filling out a form, known as 11/1, with select information concerning the route of the parade, the final destination, the potential number of people involved, the number of bands accompanying the parade, and contact information for the organizers (Hadden and Donnelly 1997: 23). Decisions about how a potentially contentious parade could proceed were to be given in writing by the police to the organizers before a parade, but such decisions could also be made or changed at any time up to or during the actual event, issued 'orally by an inspector at the scene' (art. 4, art. 4(3) cited in Hadden and Donnelly 1997: 24). Hadden and Donnelly note there are no formal restrictions on the type of conditions that may be imposed, but police have in the past "issued directions in respect of the number of marchers or bands, the furling of banners and the playing of music at particular places along the route" (24). The police may also recommend a ban on all parades in a particular area if it is deemed that re-routing or imposing conditions will not be enough to prevent the stated considerations, or if doing so would require excessive police resources. As mentioned above, the Secretary of State has the final decision regarding banning parades, and in Northern Ireland, in contrast to the rest of Britain, this decision cannot be challenged in court.

The development and implementation of the 1981 and 1987 Public Order (NI) Orders must be viewed in the context of the rising political conflict and subsequent peace process. According to Bryan (2000), the alliance between the state and Orangeism began to change as the larger political situation worsened and parades sparked increasing violence. The rise of the civil rights movement in the late 1960s saw Catholics asserting their rights to 
equality and fighting for their civil liberties. A civil rights march in 1972 led to what is known as Bloody Sunday, where the British army killed 13 people. Due to what was seen as extreme disorder, the government imposed direct rule, which transferred power from Belfast to London, and is said to have signaled a loss of control for loyalists. The conflict saw the increasing presence of paramilitaries and their increasing involvement in marches. Bryan argues that the larger political situation left Protestants feeling threatened and subsequently, parading became more sectarian and disorderly. Orange parades began to increase in number, saw the rise of 'blood and thunder' bands and more often than not appeared like a 'drunken festival' (Bryan 2000). ${ }^{14}$ The state began to separate itself from Orangeism, which started to lose its 'respectability'. Bryan claims that the rituals went from respectability to resistance and a force challenging the state itself (2000: 96). Since the 1980s, the RUC were less inclined to allow Loyal Order parades in predominantly nationalist areas, and since 1995 the police have banned, re-routed or placed conditions on parades (Jarman and Bryan 1998: np).

Bryan's anthropological analysis is useful to understand transformations in Orange parades and politics. However, I want to emphasis the role of the peace process, and the way in which the change in state policy towards the government of Northern Ireland also saw a change in tactics with respect to parading. With the progression of the peace process in the 1980s and 1990s, British policy shifted from the attempt to repress republican displays to a policy of accommodation. The state and policing powers distanced themselves from the loyalist agenda. Loyalist displays were not necessarily 'protected' in the same way they had been, as the state aimed to act more as a neutral arbitrator between two groups. The AngloIrish Agreement, signed on 15 November 1985, put the interests of the minority community

\footnotetext{
14 'Blood and thunder' bands are said to be louder, rowdier bands that play more sectarian songs
} (Bryan 2000). 
on the agenda by giving the Irish government a role in the affairs of Northern Ireland. It was not to be 'joint government', but the role was more than simply consultative, and the inclusion was strongly opposed by unionists (Bew and Gillespie 1999: 191). ${ }^{15}$ In 1995, the government continued to stress equality of treatment for 'both traditions'. The policy document, A New Framework for Agreement, stated that "any new political arrangements must be based on full respect for, and protection and expression of, the rights and identities of both traditions in Ireland and even-handedly afford both communities in Northern Ireland parity of esteem and treatment, including equality of opportunity and advantage" (para 10, iv, cited in Bew and Gillespie 1999: 304). With the state acting as the protector of rights and freedoms for all, 'disorder' was no longer automatically ascribed to republicanism.

In practice, aside from legal measures, it is important to note that there also existed an informal process of negotiation to solve parade disputes. Depending on the individual officers involved, the police might attempt to negotiate some compromise or a local mediator might intervene to help parties reach an agreement on how parading in the area could take place. ${ }^{16}$ There is therefore no sharp or neat break from one technology of control to another; rather, the new mode of governing, mediation, was already present in some form,

15 The 1985 Anglo-Irish Agreement established an Inter-Governmental Conference which was to meet regularly to discuss political matters, and other issues, including the use of flags and emblems (Bew and Gillespie 1999: 189). In line with Bryan's argument, the Agreement is said to have further fueled unionists' fears of betrayal by the British government (Bew and Gillespie 1999: 190) and to have put the community in a defensive position. Belfast County Grand Master, John McCrea, in 1993, stated to the Belfast Telegraph that "since the start of the Troubles and more so since the AngloIrish Agreement" Protestants "had to take a stand on political matters to protect their faith" (Belfast Telegraph, July 8 1993). The re-routing of Orange parades was seen as more than a policing matter. The same news article stated: The "Orange Order claims that re-routing issue now has political overtones, and that the Dublin Government is stepping up the pressure through the Anglo-Irish Agreement" (Belfast Telegraph, July 8 1993).

${ }^{16}$ See Kelly (1998) for a list of mediating groups (e.g.: the Mediation Network, Church leaders and business owners); see Ulster Community Action Network (UCAN) conference report (1996: 70) for description of police processes. UCAN was formed in 1995 after parade-related trouble in Londonderry. 
even when laws were the primary tactic. Jarman summarizes the general approach to parades in the period before the formation of the Parades Commission thus:

Initially the parades disputes were treated as a public order problem and as such it was left to the police to attempt to broker an agreement between those wishing to march and those protesting. When these attempts failed, as they almost invariably did, in spite of a variety of attempts to bring about some form of mediated compromise (Kelly 1998), the police had the responsibility to decide, using public order legislation, whether a parade should go ahead or should be re-routed. (Jarman 2003: 95)

While the negotiation process was rarely successful, as Jarman says above, such behind-thescene deals might involve negotiating part of the route in 'sensitive' areas, as well as how music and flags are used in the parade (Bryson and McCartney 1994: 154). Or it might involve negotiating a deal between residents and the marching organization where certain parades will be 'allowed' (i.e.: not protested against or blocked by residents) and not others. Mediation at the time, however, was not an organized strategy used to deal with parades. It was an informal, haphazard occurrence depending on the local context (see McAlister 2000; Kelly 1998).

Central to parade disputes was a taken-for-granted geography of politics.

Geographical space in Northern Ireland has historically been divided according to religious/political affiliation. Space is coded as either Catholic, Protestant or mixed. In practice, it was commonly understood and agreed that one could 'do as one pleases in their own areas' (Bryson and McCartney 1994). This reasoning generally governed police action, as well as the actions of those displaying symbols. For the most part, the police did not intervene so long as individuals from an opposing group could not see the display. However, when a display was objected to (whether it was seen or simply known about), and so threatened to provoke disorder, Bryson and McCartney say: "Whatever the rights and the wrongs of the issue, the authorities were likely to choose to remove the flag or emblem as 
the easier option" (1994: 148). Parade disputes, where the symbolic display of one group entered into space deemed inhabited by an opposing group, ultimately upset the tacit status quo of 'do it in your own area'.

Prior to the mid-1990s, parade disputes were regarded as individual occurrences, dealt with on a case by case basis, with no sustained governmental or public attention. There was little official knowledge about parades $;^{17}$ the government did not have a formal policy on the matter, nor (it seems) did political parties have a clear position on parade-related issues (Ulster Community Action Network or UCAN 1996: 7). There were no ‘broader principles’ for how parade disputes ought to be best resolved; there was no 'vision' for how parading ought to take place. The same disputes simply came and went every 'marching season', understood to be the summer months from April to August. Parading was seen as a problem that was confined to a relatively few locations, to a few particular parades, at certain times of the year. It was addressed as a policing matter that came and went yearly. In other words, parade disputes and any associated disorder were a normalized part of social life.

The yearly disputes around parading manifested themselves as the 'same old problem': that is, whether Protestant, unionist or loyalist parades have the right to pass through predominantly Catholic or nationalist residential areas. In the words of Jarman and Bryan in one of the first documents to address disputed parades, the long-standing problem was over 'the rights to parade' and 'rights not to suffer parades' (1995: 43). When disputes erupted, the Loyal Orders argued that marching was a civil liberty and that they had a right to march in nationalist areas based on the historical 'tradition' of using a particular road. Parades were commonly understood to be either 'traditional' marches, events which took place annually for a known purpose (often commemorative), using the same route believed

${ }^{17}$ By 'official knowledge', I mean formal governmental knowledge as opposed to local, informal knowledge. 
to be followed for generations, or 'non-traditional' parades, which referred to all other types. It is 'traditional' parades that once had legal recognition in Public Order laws and it is 'traditional' parades that the Loyal Orders felt deserved to be protected as a civil liberty, a celebration of culture, religion, and heritage. The Loyal Orders argued that any disorder surrounding their parades was caused by those opposed to the parade or the 'hangers on' (the group of young, drinking followers, for whom they argued they were not responsible). According to them, the forces of law and order should be used to protect the marchers and ensure their safe passage along their traditional route (and historically the forces of law and order did do just that).

Nationalist residents, on the other hand, argued that their consent should be sought to march in 'their areas', and that marching should not happen where it was not wanted. They argued that marches through 'their areas' were provocative, triumphalist and sectarian. Resident groups and nationalist politicians argued that parades were the source of disorder and that police should act to prevent marches that would raise community tension and provoke violence in their neighborhoods. The Irish News quoted Cardinal Cahal Daly as stating of Orangemen: "Their best service to the Ulster which they love is to march only where they can do so with dignity, with regard for the rights and sensitivities of others and with no hint of provocation" (Irish News, July 10 1993). The rights discourse at the time was deployed by both Catholic and Protestant groups, as each claimed their rights were either in need of protection or were being overlooked.

There was, then, an established discourse around parades which fit with the technology of control in place. At the time, the question was not primarily 'bow' marching might take place; rather, it was mainly one of 'to march' or 'not to march' in nationalist areas, where what counted as 'marching' was taken for granted. The technology of control in place 
involved wielding police force to dictate the same either/or choices: 'you can march' or 'you cannot march' where you wish. In practice, groups did not always take such a hard line; rather, this is how disputes were framed in public discourse and in the governmental approach. ${ }^{18}$ The police claimed they were not in a position to judge the rights and wrongs of the issue, meaning, whether a march should or should not be allowed in a certain area. They could only act based on public order concerns; that is, to decide whether a march proceeding as planned was a risk for disorder. While elements of a parade were identified by police as potential sources of disorder (i.e.: the purpose and type of parade, which bands were to be involved, the flags carried, and the music played), knowledge of these elements was tacit, informal, and unorganized. Parades were essentially unregulated in their details. Given the lack of formally accumulated knowledge, parades were for the most part, and to a certain extent only could be, acted on as a whole by re-routing or prohibiting the event. Parades were not invested in forms that allowed for their de-composition.

Despite the fact that other factors were included in the 1987 Public Order (NI) Order, the police still appeared to give the greatest weight to the threat of public disorder when making decisions about parades (Hadden and Donnelly 1997: 29). Decisions were often made at the last minute, once police could assess where the greatest threat to disorder came from. Jarman writes, "[i]f the protestors had gathered a large enough crowd of people to oppose a parade, then the parade was most likely to be re-routed. If, on the other hand, the loyal orders posed a greater threat to public order, then the parade would be pushed through" (Jarman 1999: 1423). By 1995, this was not lost on the opposing parties:

\footnotetext{
${ }^{18}$ There is evidence in the document Mediation in Practice (Kelly 1998) that in some disputes of the early 1990s, residents were not initially opposed to marches altogether, but they were opposed to how the march took place, including such things as the music played and, mainly, the behaviour of the bandsmen. Only once the dispute wore on, did residents take a harder line and oppose all parades through 'their areas'.
} 
While the police always cited the appropriate sections of the Public Order (Northern Ireland) Order, it was clear to everybody that the ability to exercise the right to march was contingent on the ability to mobilize a significant threat of force rather than a moral or legal claim to notions of human rights. By waiting until the last minute to make a decision, and often literally to the last minute, the police made it clear that whoever had the biggest crowd or could threaten the most disruption and violence would have their way. (Jarman 1999: 1423)

This logic was known to the point where groups could manipulate the process, and did so with parades in the mid-1990s culminating in a serious challenge to the police and state. Parading was an active site of political struggle and the somewhat scripted pattern of 'parade trouble' that regularly occurred changed when each side mobilized significant forces to challenge police decisions, escalating certain disputes, and ending in serious public disorder. The 'law and order' approach was challenged, the police were seen to lose legitimacy in the eyes of all parties, and the process for dealing with parades was put under review.

\section{The re-problematization of parading and policing practices}

\section{Parade disputes in 1995 and 1996}

The 1995 'marching season' saw an escalation in the number of parade disputes across

Northern Ireland. The increase in unrest at this time is generally thought to be linked to the paramilitary ceasefires declared in 1994 and the development of the peace process. Given the way parading conflicts oscillate with the political climate, Jarman notes that it is "not surprising therefore that parades should have become a contentious issue once the main paramilitary groups declared their cease-fires and emphasis shifted towards a negotiated end to the conflict and a permanent political solution for Northern Ireland" (1999: 1418). It is said that the issue of parades took on a new significance as an 'alternative site of conflict'; a field of contestation marking the continuation of the Troubles (Jarman and Bryan 1996: 41). The removal of violence heightened and intensified symbolic politics. 
The transition from outright violence to a more peaceful society is likely central to the development of government, as the 'conduct of conduct'. ${ }^{19}$ Keeping in mind Foucault's triangle of sovereignty-discipline-government, the peace process and the elimination of violence enabled a new combination of forms to develop. With the events of 1995 and 1996, in the context of the push towards peace and political/democratic solutions rather than violence, the 'law and order' approach to parades proved inefficient and unable to address the 'root' of the problem. The scale of disorder was ultimately a crisis for the state as it threatened the peace process underway at the time. The exercise of sovereign power did not disappear; rather, it provided the backdrop for the government of parades to advance.

In 1995, protests by Catholic/nationalist residents against Protestant/loyalist parades in 'their areas' increased and opposition became more organized with the formation of resident groups in many localities. Such groups started forming during the mid-1980s to oppose loyal order parades more formally, but many more were formed in the 1995-1996 period after the paramilitary ceasefires. While during the summer of 1995 there were disputes in many towns and villages across Northern Ireland, there were two disputes that attracted significant attention: The lower Ormeau area in South Belfast, and in Portadown, Country Armagh, where the route of one particular parade, the Drumcree Church parade, was highly disputed. Jarman and Bryan write that while the Ormeau Road disputes were important in the overall attention to the parading problem in 1995, they were "more localized and less symbolically powerful" than the dispute in Portadown (1996: 43). The trouble over the Drumcree Church parade attracted worldwide media attention and was the

\footnotetext{
${ }^{19}$ It is not to say that 'the conduct of conduct' could not be present in violent or conflicted societies, especially in domains other than the state (i.e.: the government of oneself or others). This is a matter that could use further investigation in studies of governmentality.
} 
center of the conflict over the right to parade, a conflict which at this time began to take center stage in Northern Ireland politics.

On July 9 1995, as Orangemen were assembling after the Drumcree church service, around 300 protestors began to block the road. The route taken back to town followed the Garvaghy Road, a predominantly nationalist area. ${ }^{20}$ On this occasion, the police advised the Orangemen that they could not guarantee their safety if they proceeded down the road and suggested that the Orangemen disperse or take the route back from which they came.

Opposing either option, the marchers decided that they were going stay at the Church until they were able to return to town via their 'traditional route'. The police were not intent on clearing the protestors or on forcing the parade through. More Orangemen and their supporters came to Drumcree and there were gatherings of support in other towns throughout Northern Ireland. Politicians, such as local MP David Trimble and Ian Paisley (as a Member of the European Parliament, MEP) made public speeches insisting on the right to march the traditional route. Paisley linked the issue to the greater political situation saying "we will die if necessary rather than surrender" (Jarman and Bryan 1996: 62). As each side held its position, with the police holding the middle line, this 'stand-off continued for two days and nights. Eventually a compromise was reached and on July 11 the parade passed down the Garvaghy Road while residents lined the side of the route in silent protest (Jarman and Bryan 1996: 61-2).

Jarman writes that by the end of the 1995 marching season, a number of complaints about the process for handling disputed parades were being made:

\footnotetext{
${ }^{20}$ That the march followed the Garvaghy Road is due to a previous re-routing decision made by the police in 1986. As the Garvaghy Road is also a predominantly nationalist area, this change continued to incite resistance. Protests were first organized by the Drumcree Faith and Justice Group, but by the mid-90s, protests were organized by the Garvaghy Road Residents Group (Jarman and Bryan 1996: 61).
} 
It was clear that responding to force of numbers was not an appropriate means of deciding issues of civil rights. It was also suggested that leaving the decision to the last minute served to exacerbate this problem as people felt the need to mobilize to ensure their interests were addressed. There was also concern that the decisions made by the police were inconsistent. In some areas, the police seemed to favor the marchers, while in others, they appeared to favor the protestors, and...in some locations, decisions varied from parade to parade. There was therefore a concern about consistency, about the criteria used, and about the transparency of decisionmaking over an issue that was accepted by all parties as a fundamental democratic right. (Jarman 1999: 1423-4)

Despite the complaints, no action was taken to make changes to police procedures. Jarman and Bryan write: "Once the crisis had been dealt with, and the Twelfth passed for another year, there seems to have been something of a retreat to entrenched positions. There was no public debate of possible long-term practical solutions to the problems of parades passing through areas where they were opposed" (1996: 68).

In 1996, parade disputes across Northern Ireland continued to escalate. While again there were disputes in many towns and villages, much of these tensions were said to have 'spread' (or spilled over) from the events of the Drumcree Church Parade in July, where the same dispute erupted over the return route of the parade from Drumcree Church. The description of events by Neil Jarman is succinct:

When the RUC announced to the Orangemen as they came out of the church that they would not be allowed to complete their traditional route, they again determined to stay where they were until the police relented....[W] hen it became clear that the police did not intend to allow the 1996 parade along the Garvaghy Road, protests erupted across Northern Ireland. Over the next three days there was widespread rioting, violence, and destruction of property. A Catholic taxi driver was murdered by loyalists. The tension increased as the Twelfth of July, the most important day in the Loyalist marching calendar, approached and, on July 11, the Chief Constable, Hugh Annesly, reversed his initial decision. The Nationalist residents were cleared from the road and the parade was allowed to complete its original route. There then followed several days of rioting, violence, and destruction of property in Nationalist areas of the north. One man was killed when he was crushed by a police vehicle. (Jarman 1999: 1424) 
Nationalists across Northern Ireland were upset at the police reversal, which lead to protests against parades and clashes between the RUC, residents, and loyalists throughout the parading season.

It was ultimately the cost of the four-day stand-off at Drumcree in July 1996 that led the government to take action. To that point, despite the trouble in 1995, Jarman et al. state that "the government had resisted calls for an inquiry into the issue of disputed parades and sustained the argument that it was a policing issue" (Jarman, Bryan, Caleyron, Rosa 1998: 3). Only after Drumcree 1996 sparked widespread violence reminiscent of the early days of the Troubles, and after it undermined the rule of law and police credibility, cost an estimated 50 million pounds in damage, and the lives of two people (Jarman 2003: 97; Jarman et al. 1998), was it, as Jarman says, "finally clear that the current means of adjudicating over contested parades would need to be reviewed" (1999: 1425).

\section{Dealing with the crisis}

On July 15 1996, just days after the events at Drumcree, the Secretary of State for Northern Ireland Sir Patrick Mayhew announced the setting up of 'The Independent Review of Parades and Marches', to be chaired by Dr Peter North, with one Catholic, Fr. Oliver Crilly, and one Protestant, the Very Revd. John Dunlop, as members. Mayhew stated the purpose of the review to be as follows (from the North Report Executive Summary): ${ }^{21}$

To review, in the light of evidence received from any interested party and having regard to the particular experience of 1996, the current arrangements for handling public processions and open-air public meetings and associated public order issues in Northern Ireland, including

the adequacy of the current legal provisions, and in particular the adequacy of the statutory criteria used in making decisions on public processions and open-air public meetings,

the powers and responsibilities of the Secretary of State, police and others,

${ }^{21}$ Available: cain.ulst.ac.uk/issues/parade/docs/north97sum.pdf 
the possible need for new machinery, both formal and informal, to play a part in determining whether and how certain public processions and open-air public meetings should take place,

the possible role for and composition of Codes of Practice for organisers of and participants in public processions and open-air public meetings,

and to make recommendations by the end of January 1997. (1997: para 2)

As noted by Mitchell Dean, the "key starting point of an analytics of government is the identification and examination of specific situations in which the activity of governing comes to be called into question, the moments and the situations in which government becomes a problem". He goes on to say that these problematizations "have particular dates and places, and occur at particular locals or within specific institutions or organizations" (Dean 2010: 38). With the launch of the Independent Review of Parades and Marches, the events surrounding Drumcree in July 1996 may be isolated as the moment parades were reproblematized: how parading took place was called into question and figured as a problem requiring government attention.

However, in contrast to Dean's position, if the aim is to "examine the different and particular contexts in which governing is called into question, in which actors and agents of all sorts must pose the question of how to govern" (Dean 2010: 38), then it would seem that the re-problematization of parading in Northern Ireland was more of a process; one that happened over time, across locations, by various non-governmental actors and groups. Problematizations are not necessarily single events.

After the disputes in 1995, documents specifically addressing the 'parading issue' began to be produced. ${ }^{22}$ Between July 1995 and the publication of the North Report in

\footnotetext{
${ }^{22}$ Prior to the disputes in the summer of 1995 there were very few works specifically on the subject of parades. To my knowledge, only Bryan, Fraser, and Dunn had published a report (1995) on parades in Portadown.
} 
January 1997, human rights groups and NGOs produced documents based on their observations of parades and policing practices (Pat Finucane Centre 1995, 1996; Committee on the Administration of Justice or CAJ 1996; Human Rights Watch 1997) and various community groups held meetings and conferences, the transcripts of which were produced (Meath Peace Group 1995a, 1995b; UCAN 1996; Northern Ireland Forum for Political Dialogue 1997). Further, two influential reports were also produced at this time. Anthropologists Neil Jarman and Dominic Bryan at the Centre for the Study of Conflict, at the University of Ulster, produced the first comprehensive report on parade conflicts (Parade and Protest: A Discussion of Parading Disputes in Northern Ireland, 1996) and legal scholars Tom Hadden and Anne Donnelly produced a report commissioned by the Community Relations Council (CRC) on the legal control of marches (The Legal Control of Marches in Northern Ireland, 1997).

It is important to examine these documents in order to place the findings of the 1997 Independent Review in context. These same documents were drawn upon in the later North Report, and most, if not all, of the above individuals and groups provided submissions to the North Review. It is clear that the North Report was by no means an independent production. The ideas that emerged here were not 'new', but were already in circulation; that is, they had already found various points of articulation. The North Report is best thought of as a performance - organized, coherent, descriptive statements about parades that emerged from the complexity of process.

In the context of the peace process, the finalities of government shifted to center on the 'bigger picture' and visions for the future of Northern Ireland. While some of these early documents and reports were calling attention to various problems involved in policing parades (e.g.: human rights violations, abusive policing practices, problems with the public 
order legislation etc.), others problematized parades in the governmentality sense: there was a struggle to specify the problem and how best to solve it. I say 'struggle' because the transcripts of the various meetings and conferences illustrate that there was no common understanding or agreement on what precisely constituted the 'parading problem'; rather, there was a process of discussion and debate, or in governmentality terms, a process of knowledge assembly and production. Such a broad, general problem did not exist prior to these discussions, but began to be constituted through them. More accurately, these early discussions or problematizations began to invest parades as a broader type of political problem; one that was solidified and made actionable in the North Report.

\section{The transformation of the parading problem}

In these early documents discussing the 'parading problem', and with the commission of the Independent Review, a new question was posed, that is, how should parade disputes be resolved? Before Drumcree 1996, there were no formal mechanisms for the long-term resolution of disputes, nor was the question of how actually to resolve disputes on the governmental agenda (Jarman and Bryan 1996: 115). It is evident that parades were now receiving increased and sustained attention. There was a general sense that this 'new focus' was a good thing and long overdue ${ }^{23}$ and a recognition that, outside of those involved in parading, not much was known about parades or the Loyal Orders: who organizes parades?; what are these organizations about?; for what purposes are parades organized?; when and where do they take place, and how many are there?; what is the relationship between bands and parade organizers? These were the types of questions raised and addressed.

${ }^{23}$ Dominic Bryan expressed this new attention at the Ulster Community Action Network (UCAN) meeting in November 1996 by noting that he could not get governmental funding for his research on parades prior to 1995 , but that now he did receive it. He also could not get political parties to respond to his request for their stance on parading, while now he asked again and every party responded (UCAN 1996). 
In general, these documents illustrate an attempt to understand the complexities of the 'parades issue'; there was a 'will to know' all aspects of it (even if the underlying aim was to prove a partisan view point). ${ }^{24}$ Various actors and groups were called upon to give their views on parading. Individuals were asked to reflect on why they parade, what parading means to them, how they feel about parades, as marchers, supporters, and as residents. Academics were called on for their views and opinions, and other parties were given a voice: mediators, church leaders, and police officers.

What emerged through all of this questioning and dialogue for the first time in a more organized form was the impact of parade disputes on the 'wider community'. As more individuals were drawn into the discussion, stating their positions, stating how parades affected them, declaring the consequences of parading for their lives and their communities, parades and parade disputes were linked to a whole series of wider relations. Local concerns linked parade disputes with adverse effects on businesses in the area; parades were said to impact the flow of traffic negatively; residents had restricted freedom of mobility and difficulty moving about town. In short, parades in general were disruptive and negatively affected daily life. Disputed parades were said to raise community tensions and increase titfor-tat attacks between local youths (though destruction of symbolic sites such as churches or memorials, or through physical violence). Neighbors from opposing groups that usually were friendly tended to avoid each other during the parading months, only to resume being friendly after the season had passed.

The issue of parading emerged as something that could divide a town into those for it and those against it, reinforcing conflict between Protestants/loyalists and Catholics/nationalists. While this notion may have existed locally and informally before, the

${ }^{24}$ Given the Northern Ireland context, this may be a more partisan 'will to know' than usually discussed in governmentality studies. 
link between symbolic displays and 'community relations' was now being documented, organized and mapped. Parades were located in the wider social and political spaces of 'the community' and began to emerge as a wider field or a problem space that required governmental intervention. Indeed, the constitution of 'community' was now central to understanding parade disputes. While parades were understood as divisive in the $19^{\text {th }}$ century, the discourse of 'community' was absent from the governmental imagination at the time. In the 1990s, the source of disorder could no longer be seen solely in the event itself, in the physical meeting of two groups, but now it could be located in the broad notion of 'community relations'.

The impact of parade disputes on the wider Northern Ireland 'community' was also made clear in these early discussions and reports. After the extensive violence associated with Drumcree, along with the peace process underway at the time, parade disputes came to be seen as intimately linked to the wider political context. In their report for the Community Relations Council (CRC), Hadden and Donnelly write: "Finding a solution to the problem of contentious marches is one of the most pressing and difficult issues in the search for peace and stability in Northern Ireland" (1997: 7). Further, they state "if a resolution based on mutual respect and toleration could be found for the marching problem, it would point the way to a wider and more lasting settlement in Northern Ireland" (Hadden and Donnelly 1997: 8). And finally, the most frequently made claim about parade disputes: "The conflict over marching is a microcosm of the conflict in Northern Ireland. In many ways it is the outward expression of the underlying confrontation between two communities and of changes in the balance of power between them" (Hadden and Donnelly 1997: 9). Parade disputes were now made to represent the state or health of the political climate in Northern Ireland. How parading took place was now an indicator of societal well-being, of progress 
towards peace and democratic politics, and it is this re-framing that positions parades and parading as an object of government.

The question of how to resolve parade disputes also entailed getting to the 'root of the problem' in order that it could be better addressed and so problems common to all parade disputes were being identified. In the main, disputes were said to be ultimately about a fundamental clash of human rights, which stemmed from, at its core, troubled intercommunal relationships and difficulties with cultural identity (dealing with difference). Part of the parades problem was deemed to be due to a lack of understanding between Catholics and Protestants, as well as to anxiety and fear between the two communities. In the Meath Peace Group talks, Bryan said that "parades are a means through which people express their identity and by which people symbolize a political opinion, therefore to block an Orange parade is understood by those on parade as an attack upon their identity" (1995a: 16; see also UCAN 1996: 32). Parades were constituted as integrally tied to the 'confidence of the Protestant people'. Elsewhere, Bryan stated:

[The parades issue] exposes the frailties of the peace process and this reconciliation process that we're told we're going through at the moment, and I would suggest that the reason why people see this as important is that because parades, demonstrations, flags, anthems and sports matter to people. They are important and if governments pretend that it's just a policing issue, we all know from working on the ground that people don't see it as a side issue. If they see their flags taken down and it they're stopped from doing that, people see that as important, it's part of their identity. And so it's dangerous for governments to try and see those sort of things as a side issue. (UCAN 1996: 6)

Bryan's mobilization of 'identity' reveals the 'work' that identity categories do. There is nothing natural or inherent about identity. Rather, identity is a production; a stabilization of the historical and constructed relations human beings have established with themselves (Rose 1996). In this case, identity was implicated in the production of parading as a domain of government. Bryan's view of parades, a view which is taken up in the later North Report, 
invests the grounds of parading in already-formed and historically constituted identity categories. Constituting parade disputes as a problem of 'identity' allows the state to adopt the position of neutral arbitrator between clashing groups. Recalling Desrosières (1990) work on 'how to make things which hold together', identity categories are a form which makes parading knowable and actionable.

As a wider societal problem of 'community' and 'identity', parade disputes were also seen to require a broader approach for their resolution. Again, in the context of the peace process, the vision of governing bodies shifted to a broader view of Northern Ireland society. In the minutes of evidence (Nov 14, 1996) of the Northern Ireland Forum for Political Dialogue (1997), Dr. Fitzduff of the Community Relations Council stated that parade disputes ultimately reflect a problem with cultural identity and that this cannot be dealt with by law alone (1997: 1-2). It was argued that the bigger picture needed to be seen: "I think we are also aware...very aware that it is probably not sensible to focus just on parades. We are facing a future that is about managing diversity...” (1997: 3). Also in the Forum meetings (Nov 21, 1996), Presbyterian Church leaders echoed the push towards seeing the bigger picture and thinking about the vision for the future. The Very Rev. Dr. Brown stated: "It seems to me that if we are going to handle the parades issue, it is not enough just to react to situations. We need to have a clear vision of where we want to go as a community" (1997: 2). Further: "If we are to build a new kind of society in this province, that society must be a genuinely multi-cultural society where the traditions of both communities are not only recognized but affirmed and even celebrated" (1997: 2-3).

Parades were now made visible in a new way; it was no longer to be a question posed of each individual event, 'is this parade a risk for public disorder?'. Rather it was: how can there be public political expression in a divided society where the same display carries 
opposing meanings for each group?; how can public space in Northern Ireland be shared?; how can cultural and political difference be managed? Ultimately, getting to the 'root of the problem' shifted how parades were viewed in the political imagination. What were previously dealt with as regular and expected public order disturbances that came and went yearly, now were to be understood as part of important societal and political problems which needed addressing. And this was not simply for the sake of those involved, but for the 'wider community' and all those with a stake in the Northern Ireland peace process. Through these various articulations, the justification for the government of parades and the extension of power into the spaces of the community and wherever contested parades took place was created.

Finally, in these early documents there was a distinct attempt to re-frame the nature of the debate away from arguments centering on 'tradition' and 'consent' towards arguments around human rights. In the UCAN conference transcripts of December 1996, Bryan noted why neither 'tradition' or 'consent' "are good ways of resolving the dispute” (UCAN 1996: 8). Against tradition, he stated that it is impossible to determine what exactly counts as 'tradition', and moreover that "tradition in terms of parades has been based on power" (UCAN 1996: 9). He argued that historical inequalities between Catholics and Protestants meant that loyalist 'traditions' had the opportunity to flourish, while nationalist ones were repressed. Therefore, allowing parades deemed 'traditional' more rights than those deemed 'non-traditional' would perpetuate this historical inequality. He also argued that consent is problematic in that it meant one community had the right to veto power over what took place in a certain area. This seemed to "be an obvious attack on freedom of expression" and it “doesn't seem to promote a plural, liberal democratic society". So, he claimed that both the arguments of consent and tradition "are the attempt of one community to express its 
position of power over another" (UCAN 1996: 10). Bryan put forward these exact

arguments a few weeks later at a different meeting organized by a governmental body (the Forum for Political Dialogue).

The tradition and consent arguments were also problematized because they created what was called a 'zero-sum game', where the outcome of disputes always had a 'winner' and a 'loser'. Either a parade was allowed and the tradition argument won, or a parade was rerouted and the consent argument won. This framing of arguments (and the corresponding regulatory measures) was identified as a central reason why disputes were intractable as they could never end with both parties somewhat satisfied. In the context of the peace process, where long term resolution to the wider conflict was paramount and negotiated settlement was the aim, the 'zero-sum game' of parade disputes emerged as problematic. The solution was declared to be in re-framing disputes in terms of a conflict of human rights, where parade disputes could be settled through what was presented to be a fair, objective, and equally applied framework.

\section{The North Report and the government of parades}

It may be said that the North Report (1997) is an overall synthesis of the ideas, notions, and views of parading articulated more widely. The findings of the report are based on a range of collected 'evidence' which was summarized and drawn on in ways to come to some overall conclusions. Beginning their investigation on August 28 1996, the review team received and read just over 300 written submissions from 'interested parties', held 93 meetings with individuals and groups, and commissioned the first major survey 'of the attitudes of the population towards parades'.

By the time the report was published in January 1997, the 'parading problem' was significantly re-specified and re-diagnosed. The root 'causes' of the issue were declared and 
an entirely new approach to deal with disputed parades was recommended. The report opened with statements of the type below:

As many people told us, the parades issue is a microcosm of the political problems of Northern Ireland. It is a complex issue which has the capacity to polarize local communities and indeed the whole of Northern Ireland. It engages in individuals levels of personal emotion and commitment to wider groupings within society that are reached by few other issues. (vi)

The events of 1996 have demonstrated that Northern Ireland remains a deeply fractured society, too often marked by misunderstanding, mistrust and fear. (1)

Both groups need to listen to each other and have a better appreciation of each other's perspective. (4)

Most telling, the report states: "The sources of the problem lie within our society - not just within the deviant political behaviour of the few, but within the inability of the many to deal positively with difference and with shared time and space" (5). Elsewhere it was said more succinctly: "the difficulties lie in the areas of flawed communal relationships" (10).

The report suggests that part of the difficulty with parades "stems from their symbolic nature lies which gives them an ambivalence, allowing them to mean different things to different people, and in particular gives them a very different emotive content for those within and those outside that particular tradition". There is a sense that this makes disputes particularly difficult to resolve. The report states that beyond the colourful spectacle, "there is an importance which attaches to parades which needs careful and sensitive analysis" (3). Parades are thought to evoke strong emotions and attachment to cultural identities. "All of us are armed with stereotypes of the opposition .... We look at one another through tinted spectacles manufactured out of arrogance, anger, fear, prejudice and suffering”. While the Loyal Orders are said to view residents' groups as manipulating/strategists (to win the long war), residents are said to view the Loyal Orders as dominating (4). The problem not only lies in different views, but more accurately, in the 
strength of commitment to them. "As we listened to groups of people...each group seemed so locked into its own experiences that each was incapable of seeing, or unwilling to see and understand, reality form within any other horizon than their own narrow one" (5).

A new and persistent theme throughout the report is a push to think about and act with consideration for others: "if resolutions and local accommodations are to be reached, it is essential that those involved understand the impact that their beliefs and their actions can have on others, an impact which may be neither intended, nor understood" (3). Part of the solution involves "both groups listening to each other and having a better appreciation of each other's perspective" (4). Responsibility is particularly laid on parade organizers: "Those who organise parades need to take account of the feelings and the historical and contemporary experience and convictions of residents of the areas through which they pass" (3).

The parades issues is linked with the broader notion of 'sharing' between communities; that is, the ability or inability to share public space, to share cultural identity and displays, as well as understandings of the past. One section of the first chapter suggests that a divided collective memory is part of the parades problem: "We all want to remember, but remembering in Northern Ireland is complicated by opposing perspectives..." (5). The report suggests there is a need to 'build a better future through a shared understanding of the past' (as per the chapter title). It asks: "Is it possible to move beyond this exercise in divisive remembering to a shared sensitive remembering which would turn parades into a shared cultural experience?" (6). There is a push to cultivate a shared history, memory, past, and a shared symbolic repertoire.

In the North Report (1997) then, parades as a problem of public order are respecified as a problem of 'community relations', where 'community' is code for relations 
between Protestants/loyalists and Catholics/nationalists. Parade disputes are now also a moral, attitudinal, and behavioral problem that cannot be dealt with by law alone. As such, the report claims what is needed is greater tolerance and understanding of the 'other'. What is needed is greater responsibility for one's actions and a greater awareness of their impact on others. In other words, what is needed is a shift in ways of thinking and acting, not just generally, but quite specifically in relation to the 'other'. Parade disputes are no longer solely isolated occurrences, but now they constitute a set of relations which are to be governed, administered, and directed in particular ways.

The report stresses that the resolution to the parades problem is to be found through mediation and local accommodation, where those involved in a disputed parade come to some consensus or agreement among themselves regarding how the parade may or may not proceed. A local accommodation is said to be the best solution because it is seen as 'communities solving their own problems' - it is seen as self-governing and to be 'outside of power', as opposed to decisions being imposed or 'forced on' communities.

The report also re-frames parades disputes as a conflict of human rights and centres a human rights framework as part of the solution. A chapter of the report is devoted to discussing 'The Wider Human Rights Framework', where the rights of both parties are located within various legal provisions, such as the European Convention on Human Rights (ECHR), and the United Nations International Covenant on Civil and Political Rights (ICCPR), among others. The report concludes that "neither the rights of marchers, nor of the members of the local community, are absolute" (109). It is argued that the position of both parties has a basis in law, and therefore, there are no winners and losers, only a give and take depending on the context. The proposals for legislative changes must allow for the balancing of these rights (an accommodation must be reached) and in "a democratic society 
this may mean that some people - potentially of any background or tradition - may have to put up with things that they would prefer did not happen" (North Report Executive Summary 1997: para 48).

While the report details a total of 43 suggestions, the main recommendation is the creation of an independent commission, to be known as the Parades Commission for Northern Ireland, to make legally binding 'determinations' regarding the management of contentious parades. The Commission is to make decisions about how parades may take place based on a set of principles using a human rights framework, where the rights of marchers and of residents are equally weighed. However, its mandate is wider than the imposition of restrictions. The primary tasks of the body are to: 'educate for greater understanding at the local level', 'promote and facilitate mediation', 'encourage local accommodation', and 'monitor contentious parades' (North Report 1997). Educate, promote, encourage, and monitor. These are hallmarks of Foucault's notion of 'government' where power works not primarily through force or prohibition, but through the 'conduct of conduct'. The overall aim of power is now to enable, support, and foster freedoms, rights, and cultural and political expression in public, primarily through 'directing' the manner and environment in which these freedoms are exercised. The goal is not solely to control disorder through public order laws - it is to create a climate where parades may take place without disorder. The advent of the North Report and the design of the Parades Commission marks a significant transformation in how power is to be exercised in relation to parades.

The North Report laid out seven 'fundamental principles' which should 'underpin the community's approach to parades in the future" (130). These are principles which it is believed should be acceptable to everyone involved, including "any responsible organisation 
which organises parades", any body which is "genuinely representative of local residents" and the "wider local community", as well as to the Government, the police, and political parties (130). These principles are:

i) the right to peaceful free assembly should (subject to certain qualifications) be protected,

ii) the exercise of that right brings with it certain responsibilities; in particular, those seeking to exercise that right should take account of the likely effect of doing so on their relationships with other parts of the community and be prepared to temper their approach accordingly,

iii) all those involved should work towards resolution of difficulties through local accommodation,

iv) in the exercise of their rights and responsibilities, those involved must not condone criminal acts or offensive behaviour,

v) the legislation and its application must comply with the Government's obligations under international law, and provide no encouragement for those who seek to promote disorder,

vi) the structure for and process of adjudication of disputes over individual parades should be clear and applied consistently with as much openness as possible,

vii) any procedures for handling disputes over parades and the enforcement of subsequent decisions should be proportional to the issues at stake. (130-131)

With the re-specification of the problem as one of 'community relations', 'relations' are now the concern of government. The focus on relations is further reflected in the suggestion that the criteria presently used by police to make parade decisions (as stated in the 1987 Public Order (NI) Order) be expanded to include one new factor: in making determinations, the Parades Commission is to consider 'the impact of a parade on the relationships within the community'. With the addition of this consideration, power is to be exercised in the name of promoting, preserving, and protecting the health of 'community relations'.

The overall aims of government in this respect go significantly beyond calling for and achieving tolerance (despite the fact that the discourse is occasionally used). Rather, 
there is an attempt to move from division to a sharing and togetherness. This is in line with what is deemed to be 'the way forward' (in terms of achieving a peaceful Northern Ireland), which is thought to lie in 'consensus and interdependence', rather than 'a further drift towards apartheid' (North Report 1997: 10). In this, the report reflects the ideal vision of governors and is rather utopian in its aims: "The future that is created can depend on a shared vision, which can accommodate and celebrate diversity, on the will to persist in working for that vision in spite of difficulties and on the kind of trust that will permit us to take risks in yielding up some of our own control of situations in favor of tackling them together" (7). Diversity is held up as something not simply to be managed, but as something to be celebrated. Further, a particular kind of subject is envisioned here, one that genuinely desires to engage with others and to reach a resolution. The 'will to persist' and to 'work together' is called for and cultivated. Finally, there is the hope or vision that parades can come to mean something else - they can represent the coming together of two communities - a celebration of difference rather than division. In this ideal society, "[m]arches and parades would no longer be seen as a pejorative and triumphal remembrance of victory by one side or the other, but a joyful recognition that together the community had created a better future" (North 1997: 11).

In the shift from 'public order' to 'community relations' and human rights, parades remain problems of policing, in the old and new sense of the term. In his 1979 lecture, Omnes et Singulatum, Foucault (2003d) shows how today's understanding of 'police', that is, of officers in uniforms fighting crime, was not always the meaning of the term. In the $18^{\text {th }}$ century, 'police' was a mode of regulating many aspects of social and economic life. 'Police' meant "the regulatory power to take coercive measures to ensure the safety and welfare of the "community" (Dubber and Valverde 2006: 2). The Commission continued to be 
concerned with public order and with the legal regulation of various elements of parades.

Also, the police, in the modern sense, remained responsible for the overall security situation at parades as deemed necessary. As scholars such as Alan Hunt and others (Hunt 1996;

Dubber and Valverde 2006) have shown, there is no sharp break between 'police' and liberal modes of government.

However, I argue that in the mid-1990s, early attempts to prohibit and restrict parading in order to deal with conflict and 'disorder', shifted significantly to attempts to encourage, entice and direct the conduct of individuals and groups. While law and regulatory rules do play a role in the government of parades as one tactic among many, it is clear that the North Report and its prescriptions go beyond the law. Law (including human rights law) is not suited to measure 'accounting for the feelings of others', or one's 'willingness to understand the views of others', or to measure the health of 'community relations' more generally. While these prescriptions cannot be legally imposed or controlled, they may be achieved through the 'conduct of conduct'. In re-imagining the space of parading in terms of societal relationships, parading is transformed into a problem requiring governmental attention. The North Report builds both a discursive framework designed to enable action on problematic relationships, and through its recommendation of a Parades Commission, it builds a technical apparatus designed to act, that is, to implement various strategies and tactics towards these ends.

\section{Conclusion}

Once dealt with primarily as a problem of public order, parading was re-problematized in the mid-1990s when violence at events escalated, threatening the wider peace process. With the advent of the North Report, parades were re-constituted in the governing imagination: they emerged as entities with the capacity either to increase division and discord within 'the 
community' or to promote a togetherness and shared celebration. The British government's approach or view of the problem fit with the dominant vision for social relations at the time. The Parades Commission as envisioned is a governing body in so far as it is designed to act on the ways of thinking and being of problem populations, and to only use more forceful means when self-government is seen to fail. The governing vision is evident in the final comments of the North Report Executive Summary:

We have been concerned throughout our work to avoid creating an Orwellian structure that bears down oppressively on the rights of groups and individuals. Parades and protests provoke passion. Our proposals are designed to provide all the interested parties with mechanisms and opportunities to work towards mutual understanding and local accommodation. We would be delighted to look back in five years and wonder why it was felt necessary to propose such major changes in legislation that addressed the problems of public order rather than promoting the community benefits of shared celebration, in the light of the subsequent positive development of Northern Ireland society. It might even be that by then the overall political situation and intercommunal relations will have stabilised to the extent that some of the structures we recommend could be dismantled. We hope so, but the choice lies in the hands of the people of Northern Ireland. (1997: para 79)

The Parades Commission was intended to provide an opportunity for parties in conflict to work towards local accommodation, where local accommodation is seen as a solution independent of state power. Encouraging local accommodation forms part of a strategy of government - one which seeks to foster active or self-governing citizens. The role of the Parades Commission was to help individuals and communities in their capacity to help themselves. As with many governing projects, there was the hope that one day, these mechanisms would put themselves out of business. The next chapter discusses the formation of the Parades Commission and its administrative procedures in more detail. 


\section{Chapter Three}

\section{The Birth of the Parades Commission and the Production of 'Contentious Parades'}

This chapter provides a basic understanding of how the Commission operated. I consider the ensemble of regulations, administrative procedures, laws, and discourses directed at parading as a space of assemblage. The assemblage, of which the Parades Commission formed a central part, produced the central object it sought to govern, 'contentious parades'. The first part of the chapter centres on the formation of the Parades Commission. I begin by discussing the mandate of the Commission in more detail. I then move to examining the reception of the North Report and the problem of finding consensus on the proposed governing procedures. I discuss the establishment of the Commission as a public body in 1997, as well as the first appointments to it, and finally, I present the 1998 Public Processions Act which gave the Commission full legal powers to make determinations. The second part of the chapter centers on the operation of the Parades Commission and provides an overview of the Commission's administrative procedures. I examine the Commission's information-gathering practices which, I argue, worked to invest 'contentious parades' as a tangible, governable object. In the final part of the chapter, I discuss the Commission's Code of Conduct. The analysis of the Code illustrates how governing parades was an attitudinal and behavioural project.

\section{The establishment of the Parades Commission}

\section{The basic duties and mandate of the Parades Commission}

As the previous chapter outlined, the main recommendation of the North Report was the creation of a new independent body, to be called the Parades Commission for Northern Ireland (PC or 'the Commission'). The Commission would function in the following manner, considering parades on a case by case basis. It would:

a) allow interested parties to put their views forward about proposed parades, 
b) encourage them to settle difficulties locally, and where that proved impossible,

c) itself come to a view on what, if any, conditions should be imposed on contentious parades after an appropriately transparent process of examination of all the relevant issues against the background of reformed legal provisions. (North Report 1997: 138)

The Parades Commission would combine the following five roles:

1) Education: The first "key function of the Parades Commission will be to encourage greater understanding at the local level of the perceptions of the two sides of the community in respect of parades and their significance". It was thought that if "rights and responsibilities are more clearly understood", then "there is a greater chance that restraint will be exercised", increasing the likelihood of reaching local accommodation (North Report 1997: 142). A 'local accommodation' entailed parties coming to some agreement among themselves on how parading may or may not take place.

2) Promoting and facilitating mediation: The Commission is to work to promote and facilitate mediation where parades are disputed, with the aim of achieving a local accommodation. Mediation was now made part of the formal procedures for dealing with disputed parades. As envisioned, it was to be the first attempt, and ideally only, means required to find a resolution to disputes. The Commission would only enter into its next role, adjudication, if mediation has been unsuccessful.

3) Adjudication: If mediation fails, then the third role of the Commission is to consider, in place of the police, what conditions might be imposed on individual parades. These conditions were to be set out in documents called 'determinations'. Establishing the guidelines and procedures for making determinations is by far the most complex aspect of setting up the Parades Commission.

4) A code of conduct: The North review suggests that the Commission develop a Code of Conduct outlining acceptable and unacceptable behaviours at any parade. It is to keep the 
Code under review and amend it as it sees fit.

5) Monitoring: The Commission is to arrange for contentious parades and protests to be monitored (North Report 1997: 140).

The response to the North Report and the need for consensus

After the publication of the North Report, the Secretary of Sate for Northern Ireland, Sir Patrick Mayhew, made a statement to the House of Commons on January 30 1997. Part of this statement was reproduced in the Introduction chapter. On behalf of the Government, Mayhew endorsed the North Report and supported its overall approach to solving disputes. He emphasized that the 'fundamental principles' laid out in North, which form the basis for new procedures governing parades, "include both the protection of the right to peaceful free assembly and the need to ensure - preferably through local accommodation - that the exercise of that right takes proper account of foreseeable effects on relationships within the community" (Hansard, vol 289 cc 507). Mayhew stated that the government recognises the report's description of the parades issue 'as a microcosm of the wider political problems of Northern Ireland' which can 'polarise the community' and 'engage levels emotion and commitment' reached by few other issues. He emphasized that because of this potential, it was important that whatever new arrangements were put in place have widespread support. Such arrangements must be "recognised as fair and workable, and therefore acceptable" (Hansard, vol 289 cc 508).

The dialogue in the House of Commons after Mayhew's statement reflects part of the struggle to re-frame parade disputes as a problem of 'community relations'. While nationalists and residents' groups generally accepted the recommendations of the North Report (Jarman 1999), unionists were largely critical of and opposed to the report's findings. Unionists in the House, such as David Trimble, appeared to want to maintain the parades 
issue primarily as one of public order. After Mayhew's statement, Trimble asserted that the “overriding need is to maintain the Queen's peace and to leave the highways free for all who wish to proceed along them peacefully" (Hansard, vol 289 cc 512). Further, he stated that while he understood the desire to promote conciliation, "some elements in society in Northern Ireland are determined to use the problems to create serious public disorder". The 'elements in society' to which he was referring are the IRA and the political party Sinn Féin. He argued that these groups were "the basic underlying problem" (Hansard, vol 289 cc 513). Other unionists in the House called the North Report a 'fantasy world' and claimed that "the IRA is committed to ensuring that there is no community agreement" (Hansard, vol 289 cc 521).

Mayhew responded by stating that while parades give rise to public order issues, "the issues are not limited to public order. They give rise to wider aspects, which may be described as aspects of community relations or political aspects" (Hansard, vol 289 cc 513). Mayhew stated there has "been a sharp worsening of community relations since the events of last summer. There is no doubt about that. Everybody I know of agrees that there has been an increased polarisation and an increase in fear and bad relations between the two sides of the community" (Hansard, vol 289 cc 519). ${ }^{25}$ He repeatedly stressed that the most important thing is "getting the will to co-operate, or local agreement". While legislation can play a part, there needs to be a "desire for a sensible and workable means to be achieved" (517). "Time and again the [North] report comes back to the need for wide acceptability of mechanisms and procedures" (Hansard, vol 289 cc 520).

${ }^{25}$ Interesting to note that in the absence of definite measures or indicators, there comes to be some collective agreement on the overall state of 'community relations'. 
Gaining consensus on governing measures was now the central requirement of the new approach towards parades and to the political conflict more generally. Echoing Mayhew's statement to the House, the next Secretary of State for Northern Ireland, Marjorie (Mo) Mowlam, stated in October 1997: "What is needed on the parades issue, as elsewhere, are policies capable of winning the allegiance of everyone, because they are based on clear principles, and because they recognise the rights and aspirations of all" (Mowlam 1997: 2). The aim was to design a governing approach that had the support of all parties. She stated that the government is "convinced the way forward is a policy based both on rights, and on the responsibilities which go with them" (Mowlam 1997: 1). She went on to say that "rights underlie our approach...because they are the natural heritage of all, regardless of political affiliation....also because we believe that a system based on transparency and recognised rights stands the best chance of success even in the vexed area of marching" (Mowlam 1997: 4). In other words, 'rights' form a common language, or a common ground on which all parties in Northern Ireland can agree. Essentially, the human rights framework was thought to create a certain consensus among parties in conflict.

The desire for consensus on governing procedures, not a concern in the law and order' approach to parade disputes, forms part of the new strategy of government. Governing bodies need to cultivate subjects who are willing participants in their own governance. Towards this end, the new approach was about making regulatory procedures more explicit and more visible. Regulatory procedures and decisions now must be rationally explained; they must adhere to some form of reasoning. In this case, the reasoning brought to bear was that of human rights. By making governing procedures more transparent and acceptable (by appearing 'objective' and 'fair'), individuals and groups are not likely to protest or challenge regulatory decisions. Finding consensus on governing procedures is a 
strategy of pacification, while at the same time allowing for the specification of regulations for the conduct of individuals in relation to themselves and others. In other words, while regulatory procedures appear to become less state-centered and to use 'less power' in the usual sense, such discourse and procedures render the exercise of power less visible.

While the recommendation of a Parades Commission was accepted by the Government, the proposal that the Commission should take over RUC decision-making power in respect of parades was seen to be "a radical and far-reaching one" (Hansard, vol 289 cc 508). Secretary Mayhew announced that the Government would begin a two month consultation process to hear views on this proposal before moving forward with it. In the meantime, the Government would establish "an independent body of five people, to be known as the Parades Commission, with the mediation, conciliation and education roles recommended in the report" (Hansard, vol 289 cc 509).

\section{Classifying the Parades Commission as a public body and first appointments}

Deciding what kind of body the Parades Commission should be significantly depended on the kind of powers it was to have, or in this case, was likely to have in the future. J M Steele, the Director of Policing and Security at the Northern Ireland Office (NIO), wrote to the Machinery of Government Division (London) regarding the procedures he intended to adopt to establish the Commission. He wrote that since members would be appointed by the Secretary of State, he intended to classify the body as an executive non-departmental public body (NDPB). The UK government defined a non-departmental public body, also known as a 'quango', as "a body which has a role in the processes of national government, but is not a government department, or part of one, and which accordingly operates to a greater or lesser extent at arm's length from Ministers". ${ }^{26}$ However, Steele noted the Commission was not a

\footnotetext{
26 http://www.archive.official-documents.co.uk/document/caboff/bodies97/intro-1.htm
} 
typical executive body. "Its decision making powers make it more like a Tribunal, while the role as ultimate decision maker with no right of appeal (except in the specific case of the Chief Constable) gives it some similarities to an Ombudsman". He intended therefore to classify it in the 'other' category of NDPB. A reply from the Machinery of Government office told Steele that the classification of 'other NDPB' was solely for boards of visitors to penal establishments and he suggested an alternative:

However, as you recognise, the Commission will have a unique role, and may have decision-making and ombudsman-type powers, which makes it difficult to fit neatly into any one category. Moreover, it will presumably need to be seen to be as independent from the Government as possible. We therefore suggest that, providing you are satisfied that the appropriate financial mechanisms are in place, the Commission should be set up as an independent statutory body. (Howie to Steel, 11 Feb 1997) ${ }^{27}$

The Commission was unique in that it was intended to combine two usually separate functions, that of making decisions, similar to a tribunal, and that of investigating and resolving disputes through mediation, similar to an Ombudsman. As an independent statutory body, the Commission would have its basis in law and function more or less autonomously from the government. However, the body would have government funding and members were to be appointed by the Secretary of State.

Regarding appointments, Steele wrote to Sir Len Peach, the Commissioner for Public Appointments for Northern Ireland, to seek his suggestions on the intended procedures. He stated that as members were likely to be appointed by the Secretary of State, the Commission would not fall within Peach's remit. However, the NIO wished to follow the Commissioner's guidelines as closely as possible as a 'matter of best practice', while keeping in mind there are tight time restraints in the initial establishment of the Commission:

${ }^{27}$ Correspondence between Howie and Steel on file with the author. 
You will appreciate the great urgency in setting up the body in time to allow it to play a role in this year's marching season. Identifying suitable members with the necessary stature and able to give up the considerable time necessary will be difficult, and we are clear that going through the full procedures set out in your guidelines would make it impossible to set up the body quickly enough. (Steele to Peach, 7 February 1997)

Sir Len Peach responded that given the constraints of the situation, "it seems to me that it will be unnecessary to advertise such posts. The creation of a suitable scrutiny panel with Dr. Maurice Hayes acting as the independent member [suggested by Steele in his letter], using names drawn from various sources, including departmental lists, will be adequate" (Peach to Steel, 17 February 1997). ${ }^{28}$

The Parades Commission was set up on 26 March 1997 as a non-statutory entity. It was to begin as a non-legal body carrying out all its roles, except that of making determinations. Alistair Graham, a long-time public servant and trade union leader, was named as the Chairperson. Four commissioners were appointed: David Hewitt, a solicitor; Rev. Roy Magee, a unionist and Presbyterian minister; Frank Guckian, a Londonderry businessman; and Berna McIvor, a nationalist and member of the Social Democratic and Labour Party (SDLP). The appointments were for a period of two years. During the summer of 1997, while the PC was to educate on the parades issue and work towards facilitating mediation, it was limited in its effect. Since the government decided on a period of further consultation before implementing the key proposals of the North Report, the Parades Commission "effectively had a watching brief over the events of the summer" (Jarman et al. 1998).

One of the first challenges faced by the new Commission was the question of its independence and impartiality. The public perception of the Parades Commission in 1997 was influenced by two key events (Jarman et al. 1998). A Northern Ireland Office document

${ }^{28}$ Correspondence between Steel and Sir Len Peach on file with the author. 
was leaked which implicated Alistair Graham in the decision made by police to remove protestors forcibly and to allow a parade down the Garvaghy Road on July 61997 (Jarman 1999: 1434). The result was a public perception that the "chairman of the Parades Commission already had a view on the Drumcree parade" (Jarman et al. 1998). The second event occurred when one of the Commissioners, Rev. Roy Magee, played a role in facilitating mediation and finding agreement on several disputed parades. This raised concern over the role of the Parades Commission: "Could Commissioners be involved in mediation if legislation was also to give them powers to make determinations as well?" (Jarman et al. 1998). Rev. Magee resigned with effect from December 311997 over the potential conflict between the two roles. Berna McIvor also resigned with effect from February 181998. According to a media report, McIvor's departure was seen as the SDLP “expressing its disapproval of the Parades Commission's current direction” (Sunday Tribune, March 1 1998). The Public Processions Act

The development of the Parades Commission was delayed until after the 1997 General Election which was won by the Labour party. On October 17 1997, in a speech at the University of Ulster's Jordanstown campus, the new Secretary of State for Northern Ireland, Marjorie (Mo) Mowlam, announced the publication of the Public Processions Etc. (Northern Ireland) Bill. The Bill, which would later become the Public Processions (NI) Act 1998, was designed to implement the full recommendations of the North Report (i.e. to create a Commission with the power to make determinations). Interestingly, the original Public Processions Etc. (NI) Bill contained a clause that would allow for the Commission to govern all public manifestations of cultural identity if they were deemed by the Commission potentially to harm relationships within the community (see Jarman et al. 1998; Jarman 1999; 
Baber 1998: 38) ${ }^{29}$ Mo Mowlam supported the inclusion of this clause in her announcement speech: "We have also looked at claims that establishing a Parades Commission focuses too narrowly on a method of expressing cultural identity which, in practice, is undertaken particularly by one side of the community...The problems of fear and intimidation as a result of aggressive manifestations of community relations are not only found in the parades context" (Mowlam 1997: 4). The clause was intended to ensure that all problematic or 'aggressive' expressions of cultural identity would be attended to, or perhaps more accurately, to counter the perception that the bill unfairly targeted loyalist expressions. Jarman (1999) says the clause was apparently included to appease unionist opposition to the bill.

After extensive debate in the House of Lords, it was decided that the clause would do more harm than good. There would be difficulty defining what counts as 'expressions of cultural identity', likely bringing into question all manner of displays that at the moment were not contested, like painted curbstones, murals, and Orange arches. ${ }^{30}$ According to Lord Alderdice, the Commission would become mired in this difficulty rather than help solve a problem around parades (Lord Alderdice cited in Baber 1998: 39). Lord Dubs stated it was agreed the clause 'would not have the desired effect' and it was removed from the bill (Dubs cited in Baber 1998: 39). While this clause was removed, another clause was added which required advanced notice for protests. As protests against parades are a largely a nationalist endeavor, Jarman says the additional clause was seen to "impose some degree of balance by

\footnotetext{
29 The bill, however, expressly excluded sporting events. Interestingly, sporting events were generally excluded from legislation targeting 'cultural' or symbolic expressions. While conflict and disorder around parades was understood as a manifestation of problematic 'community relations', justifying their regulation, disorder around sporting events remained a problem of 'public order', despite the fact that such politically-oriented conflict could be argued also adversely to impact 'community relations'. This begs further questioning and analysis.

30 This further indicates that governing parades is, in fact, about governing relationships that manifest themselves 'problematically' such that contestation or disorder results.
} 
extending the controls to both parties to the disputes" (1999: 1430). Eventually the bill was enacted as the Public Processions (Northern Ireland) Act in February 1998.

The Public Processions (NI) Act $1998^{31}$ established the Parades Commission for Northern Ireland as a non-departmental public body, endowed with powers to make legally binding decisions regarding contentious parades.

The Act sets out the duties of the Commission as follows (clause 2(1)):

(a) to promote greater understanding by the general public of issues concerning public processions;

(b) to promote and facilitate mediation as a means of resolving disputes concerning public processions;

(c) to keep itself generally informed as to the conduct of public processions and protest meetings;

(d) to keep under review, and make such recommendations as it thinks fit to the Secretary of State concerning, the operation of this Act.

The Commission may act to (clause 2(2)):

(a) facilitate mediation between parties to particular disputes concerning proposed public processions and take such other steps as appear to the Commission to be appropriate for resolving such disputes;

(b) issue determinations in respect of particular proposed public processions.

As recommended in the North Report, clauses 3, 4 and 5 dictate that the

Commission shall issue three documents: A Code of Conduct, Procedural Rules, and a

Guidelines document setting out a list of factors the Commission is to consider when

making determinations. All documents are to be kept under review by the Commission and may be revised as necessary.

Clause 8 deals with the Commission's power to impose determinations on a public procession. The Commission will only make determinations in relation to contested parades where a local decision cannot be reached. The nature of the conditions imposed on a parade

31 Available: http://www.legislation.gov.uk/ukpga/1998/2/contents (accessed July 7 2012). 
is left to the discretion of the Commission. When making determinations, the Commission is to consider the following factors:

(a) any public disorder or damage to property which may result from the procession;

(b) any disruption to the life of the community which the procession may cause;

(c) any impact which the procession may have on relationships within the community;

(d) any failure of a person of a description specified in the guidelines to comply with the Code of Conduct (whether in relation to the procession in question or any related protest meeting or in relation to any previous procession or protest meeting); and

(e) the desirability of allowing a procession customarily held along a particular route to be held along that route.

The Act allows for the police and the Secretary of State to retain significant power.

The Chief Constable can appeal to the Secretary of State to review any Commission determination. The police also retain its powers under the Public Order Order to act as necessary to maintain public order at any event regardless of Commission decisions. The Parades Commission is not granted the power to prohibit processions; rather, this power remains with the Secretary of State.

Clause 13 sets out provisions for the control of alcohol at parades. Measures to control alcohol were already in place under the Public Order Order, but were not enforced (Jarman 1999: 1432). Finally, clause 14 makes it illegal to disrupt or prevent a lawful procession. Failure to comply with the Commission, such as to give appropriate notice of a procession, or failure to follow Commission determinations, are also made offences, all punishable by a period of imprisonment up to 6 months or up to a 5000 GBP fine.

The Commission did not remove or replace the police from its traditional responsibility of policing processions. Parades were still potential problems of public order to be policed on the ground, and to this end, the police continued to play a part in governing parades. However, in place of policing decisions, the Commission was now to determine how parades may proceed using a set of principles and guidelines against which to judge each 
'contentious parade'. The creation of the Commission added a new administrative power over the politics of parading.

Aside from the establishment of the Parades Commission itself, there are two significant changes ushered in the by the Public Processions Act. There is the addition of the factor 'the likely impact of the parade on relationships within the community' when considering how a parade may proceed. As previously noted, this is a new factor; one that was not considered by the police under the Public Order Order. Also, there is now to be a 'Code of Conduct' governing behaviour at all parades, and compliance with the Code is to be a factor considered by the Commission when making determinations.

The Public Processions (NI) Act allowed the Parades Commission to begin operating with full powers to make determinations. In that first year, problems with appointments persisted. With the passing of the Act in February 1998, the Secretary of State, Mo Mowlam, announced new appointments to the Commission. Alistair Graham was reappointed as Chairman for a one year term, along with commissioners David Hewitt and Frank Guckian. Newly appointed were RoseAnne McCormick, a barrister and Catholic who served as a member of the Police Authority for six years; Aidan Canavan, a solicitor, and also a Catholic; Glen Barr, a loyalist activist; and Tommy Cheevers, also a loyalist and member of the parade organization, the Apprentice Boys of Derry. The new appointments, especially those of Barr and Cheevers, created controversy. Both were 'working-class loyalists' and seen as too close to one side of the conflict. At the same time, the two Catholic members were seen as too middle-class and with views too closely aligned to the state (Jarman 1999: 1435). The republican paper, An Phoblact, reported McCormick and Canavan as having no nationalist links. The paper also cited residents' groups who claimed that the Commission was a 'unionist Commission for a unionist people' and that it could not adjudicate on 
parades fairly (An Phoblact, February 26 1998). Barr and Cheevers eventually resigned and were replaced by less politically involved members (Jarman 1999: 1435). In June 1998, Barbara Erwin was appointed, who worked in the higher education sector, as was Billy Martin, a County Down farmer.

\section{'The Commission in Action'}

The government of parades was to occur through a standardized format for processing each parade deemed contentious. This section serves as a broad overview of PC processes and administrative procedures. The primary aim of the Parades Commission was to create conditions where disputed parades could take place without violence or disorder, and ideally, without protest. The best way to achieve peaceful parading was deemed to be through having those involved in disputes find an agreement among themselves. Dialogue was seen as the ultimate means to achieve a local agreement and as such, fostering 'genuine dialogue' and 'engagement' was a central goal of the Parades Commission. Mediation was the primary governing strategy deployed to facilitate such dialogue. If mediation failed to bring about a local accommodation - in other words, if parties were deemed unable to govern themselves - only then would the Parades Commission intervene. At that point, the PC would make a ‘determination' - a legally-binding decision based on a series of set guidelines and human rights considerations regarding how the parade may or may not take place (with certain restrictions or conditions). Therefore, the PC worked with a two-pronged approach. The body was first to foster the self-government of groups, and failing that, it was to take a more coercive approach and impose a decision backed by law.

The assemblage of laws, administrative procedures and discourses worked to render parades visible in such as way that they appeared amenable to governmental intervention. It was through the assemblage that the governing object was produced, rendered knowable, 
and acted on towards desired ends. The system of relations between the different elements of the assemblage was mobile, fluid, and changed over time; the assemblage was a flexible arrangement and adjustments were constantly made to 'govern better' or more efficiently. It was through the assemblage that the elusive, intangible, incoherent space of parading was 'captured' or made visible to governing bodies, and so rendered a field of intervention.

The chairperson and commissioners, appointed by the Secretary of State for set terms, formed the core of the governing body. The Commission's work was supported by a secretariat made up of civil servants from the Northern Ireland Office (NIO). In 2009, there were twelve staff in total. Since its inception, the Commission has occupied the $12^{\text {th }}$ floor of a 23 floor high-rise office building in central Belfast. The office is a centralized administrative space for the government of parades. This was where the secretariat worked and where meetings were held.

A central plank in the governing program was the deployment of trained mediators, called 'Authorised Officers' (AOs). Authorised Officers were the main link between the governing body and the field of intervention; that is, the sites and spaces where parading took place. Initially, AOs were hired from an organization called the Mediation Network for Northern Ireland (MNNI) and worked on contract for the Commission. In its third year of operation, the Commission hired and worked directly with AOs. The main task of AOs, which I further discuss in chapter four, was to promote and facilitate mediation in order to achieve a local accommodation. AOs were also initially responsible for observing, monitoring and reporting on parades, until this function was transferred specifically to a group of monitors. Beginning in its third year, the Parades Commission deployed a team of volunteer monitors who were to attend parades as 'neutral observers'. Figure 1 depicts the 
Figure 1 - 'The Commission in Action'

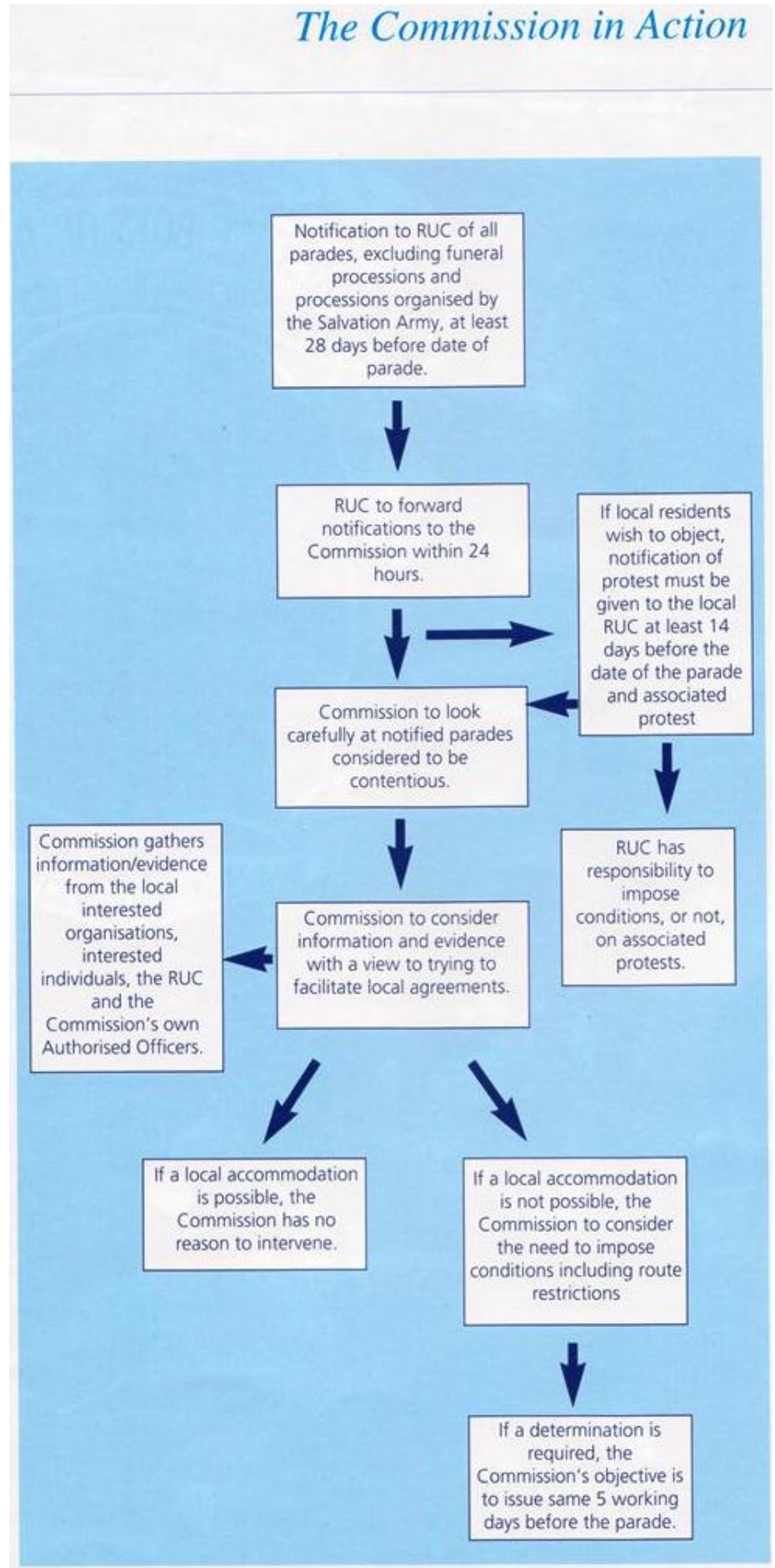

Source: Parades Commission First Annual Report, 1998-1999, pg. 24 
new procedures for regulating parades, or what the First Annual Report (PC 1999) called 'the Commission in action'.

The production of the object of government: 'contentious parades'

The parading assemblage produced the central object it sought to govern: 'contentious parades'. This was the single most important sorting or classificatory procedure which determined where governmental attention was required. The category of 'contentious parades' is a way of investing social life in governmental and administrative forms. In other words, 'contentious parades', like the concept of population, is a way of governing wider dimensions of social life, in this case, social relations deemed to be conflicted and symbolic politics. 'Contentious parades' were invested through information gathering documents, the first being Form 11/1, titled 'Notice of intention to organise a public procession'. ${ }^{32}$ This form was in existence prior to the Parades Commission, as Public Order laws already required notification of parades to police. Under the Public Processions Act, in order to have a legal parade, parade organizers had to notify police of their intent to parade at least 28 days prior to the event. Exceptions were made for funeral processions and processions organised by the Salvation Army. Organizers of all other parades had to complete the Form 11/1. The $11 / 1$ was the only way for a parade to be considered by the Parades Commission. The form was a total of eight pages long and asked organizers to report on the parade in detail. The form marked the moment when 'a parade' entered into the governing regime. The information detailed in the document provided the first material representation of a parade - the object was rendered visible in a particular way based on the information collected - and this formed basis on which government could act.

32 Available: http://cain.ulst.ac.uk/issues/parade/pc/pc060605npa.pdf (Accessed November 5 2013). 
Part 1 of the 11/1 consisted of the parade organizer's details. The organizing body was to be listed, and the individual organizer (who was to be filling out the form) was to be identified, along with their contact information. Part 2 consisted of the parade details organized in three sections. The first section gathered the identifying details of the parade: The date, precise time, and location of the outward route, and if applicable, the return route. The purpose of the parade was also to be stated here. The form asked for the anticipated number of participants including band members, the number of bands, and the likely number of supporters. It asked whether 'uniform/regalia' would be worn, and whether banners/flags would be carried. If the purpose of the parade was to attend a 'religious service/public meeting', the location, start and finish time were to be listed. The second section asked for the details of the proposed parade route and each street was to be listed, while the third section collected information on the parade organizer's 'control arrangements'. Questions were asked such as: how many marshals will be in attendance? And, what are their names? Further questions included:

- Have they had formal training? If 'Yes', details were to be provided.

- What form of identification will be worn by marshals? Options listed were: Armbands, Coats, or Other (to be specified).

- What method of communication will there be between the organiser and marshals during the parade? The options listed were: Mobile telephone, radio, or other to be specified.

- What method of communication will there be between: Organisers/marshals and police? Organisers/marshals and other emergency services? The options listed were mobile telephone, radio, verbal or other to be specified.

Part 3 of the form inquired about the bands accompanying the parade. Only bands listed here were allowed to take part in the procession. For each band (and there could be many), the name of the band, the town of origin, and the number of people in the band were to be recorded. Part 4, the final section, applied to cases where the procession and/or band 
members would travel together to another destination. Details were to be recorded such as the destination, the method of travel used, and the time of arrival.

Organizers were to sign and date the form, confirming that "I have read and understood the booklet 'A Code of Conduct' and that I am aware of my responsibilities as a parade organiser. I confirm that the information I have given is correct to the best of my knowledge". After it had been handed to an officer not below the rank of sergeant, the officer was to check if all sections of the form were complete, and was to offer a copy of the Parades Commission's statutory documents (A Code of Conduct; Procedural Rules; and Guidelines). This Code of Conduct is discussed below.

The submission of the $11 / 1$ was the moment the object of government became mobile and actionable within the governing assemblage. The Form 11/1 was then forwarded to the operational planning division of the police, where it was recorded, and faxed to the Parades Commission with another form filled out, the $11 / 4 .{ }^{33}$ The $11 / 4$ contained the following questions to which the police were to provide a brief explanation:

1. Is this notification an annual parade?

2. Does this parade pass through any other DCU? [District Command Unit]

3. Has this parade previously been subject to a determination?

4. Are there any local concerns or sensitivities which the Commission should be made aware of?

It was through this mundane procedural process and the $11 / 4$ that a central governing tactic was deployed: Police were to stamp the $11 / 4$ form with the word 'contentious' if the parade was deemed by police to be one where there was the potential for conflict. This stamping in itself may be considered a symbolic means through which parades were governed. The designation of contention acted as the primary mechanism flagging 'problem' parades; that is, parades that required governmental intervention. Once marked as 'contentious', the object

${ }^{33}$ Before the PC was in existence, the Form 11/1 stayed with the police and they made a decision on how the parade could proceed using the Public Order law. 
entered into the 'governing field of visibility'; it was brought under the gaze of the Parades Commission from this point forward. ${ }^{34}$ How 'contention' was determined exactly was never explicitly specified and it remained a question, or a point that continued to require clarification, throughout the life of the Commission. In practice, it seems that both the police and the Commission played a role in determining contention. The police flagged parades it deemed contentious, however, the Commission may have disagreed, or decided a parade not usually classified as contentious now deserved to be categorized as such (due to changing political circumstances for instance).

In addition to sorting parades as 'contentious' and 'not contentious', the 11/4 worked to transfer to the Commission police knowledge of the specific parade notified, organized according to what was deemed important information. This information formed part of the 'evidence' that went into making a determination. The question of 'local concerns or sensitivities' signaled where and with what the Commission ought to be concerned, and given the lack of need to explain what precisely the Commission felt it ought to be made aware of, the question relied on common understandings or tacit police knowledge as to what counted as a 'local concern' or 'sensitivity'. There was an underlying common agreement produced on those instances/events/happenings that counted as a 'local concern' or 'sensitivity'. Such 'local concerns or sensitivities' may be understood as code for potential risks to 'community relations' and so disorder. The production and deployment of tacit knowledge and an underlying common agreement on what counted as potential risks was an important part of how parades were governed (how determinations were made and justified).

\footnotetext{
${ }^{34}$ Parades not flagged as contentious were posted directly onto the Commission's website by the PC secretariat to proceed as planned in the 11/1.
} 
What was a 'parade' then, in the governmental imagination? A 'parade' was not simply a moving mass of people and props - a parade in this sense was not the object of

government. Rather, a 'parade' was constituted as involving specific types of people, moving and expressing themselves in specific ways, with specific types of props, in specific locations. It was the specificity of a 'parade' in this sense that the Commission worked to invest in order to direct its elements, both material and symbolic, in desired ways. One of the central tactics the Commission used to attempt to direct a parade in this sense, was the Code of Conduct. As the Code was a measure meant to apply to all parades, which came into effect when parade organizers submitted the notification to parade (the 11/1), I discuss it here. The rest of the thesis centers on the strategies and tactics directed specifically at parades deemed contentious.

\section{The Code of Conduct: An attitudinal and behavioural project}

To govern parades as problems of community relationships was an attitudinal and behavioural project and the Code of Conduct (PC 1998) is a central tactic through which the Commission worked to instantiate new norms for how parading ought to be organized and practiced. All parades were subject to the Commission's Code of Conduct and compliance with the Code was a factor to be considered by the Commission when making determinations.

The Code of Conduct aims to shape, guide, and direct how individuals and groups exercise their freedom to march, such that conflict may be avoided. In the Code, parades are constituted as having the potential "to inflame emotions in local communities and cause widespread disorder". Such emotional reactions are seen as uncontrollable states, lacking rationality and reason. This description fits with how parades have been described to be like 
wildfires or diseases, where disorder in one area can 'spread' or set off disorder in another location.

While the Code governs individual marchers, the thrust of the document is aimed at parade organizers; those deemed responsible for the entire event, and thus also for the space (environment, atmosphere) of parading. The Code is intended to be "a source of advice for those organizing parades and marches for any purpose in public places. It is designed to assist organizers by providing both a checklist and reminder of the points they will need to cover and the issues they will need to address in planning, and on the day" of the event.

The first part of the document highlights several factors parade organisers ought to consider when planning a parade. These are 'considerations', 'suggestions', 'possibilities to explore', indications of 'prudent' actions, and what 'should be borne in mind', as well as statements of what will be 'necessary' and 'important' to undertake. The document also gives explicit indication as to how these factors might be taken into consideration, and it provides examples of why such action might be necessary. Governing is not just about listing prescriptions, but about giving a reason why such behaviour should be taken up.

Much space is devoted to the route of the parade. The document states, "[w]hile many of the routes may be traditional, in other words routes that have been followed by parades for many years, in finalising the route it will be necessary for organisers to gauge the following factors:".

\section{i) Will the parade dismpt commercial activity?}

Organisers are told "it would be prudent to give those who carry out business in the area the maximum possible notice of the intention to hold a parade". This is necessary in order that such individuals "might make alternative arrangements for receiving deliveries etc." The 
document also states how giving notice might be done, for instance, through distributing 'flysheets' with the parade details.

\section{ii) Does the route pass churches or other places of worship?}

If the route does pass churches or other places of worship, "it will be important to determine beforehand whether any services, weddings or meetings will be taking place at the time of the parade". This might be done through "approaching the relevant clergyman". If there are services, and "it is not deemed possible or feasible to re-route the parade, parades organizers should explore the possibility of adjustment being made to the time of the parade in order to avoid disruption in access to or egress from the premises".

\section{iii) Will the route pass through a residential area?}

The Code states "it is a matter of courtesy to let local people know" of a parade by "for example, placing a notice in the local paper or distributing flysheets, with the details of the parade as early as possible so that individuals might make any adjustments necessary to their

daily patterns of activity". It gives the examples of giving individuals time to change a normal shopping routine or hospital or other appointments.

It further states that "if the parade will pass through an area where people of another cultural identity live, it will again be necessary to serve early notice and to include in that notice details of the person to whom representatives of the local community might approach about aspects of the parade". In addressing such situations, the Code speaks directly to parade organisers:

In event of such representations being made it will important to take whatever steps are reasonable to meet residents concerns. In many cases, this is likely to amount to little more than the furling of banners and adjustments to the music to be played, but organisers should also consider alternative routes. Where it is not possible to reach agreement on self-imposed restrictions, it will be important to take steps to establish a line of communication aimed at achieving accommodation on the proposals for the parade. 
Where "communication is problematic, disputants should avail themselves of assistance from facilitators". The Parades Commission can help by suggesting trained individuals. iv) Will the route pass along a main road or arterial route?

The document states it will be important "to ensure that stewards are well informed" of how to act in an emergency situation, should an ambulance or police vehicle need urgent access along the route.

Taken together, it may be said that these route considerations work to create a concern on the part of parade organisers for 'the community' and the 'everyday lives' of those who live there. They work to create an awareness of how parades impact others, and the document offers explicit direction as to how parading might be organized such that it may occur in harmony with the local community. Further, this part of the Code is concerned to enroll parading organizations to make voluntary changes to their parade routes, no matter how long-standing. By making earlier reference to 'traditional routes', it would seem the Commission is addressing resistance from the Loyal Orders, who have argued their traditional routes deserve legal protection (protection they have historically had, informally and formally). More generally, the Loyal Orders have resisted any changes to their parading practices and this is considered in the development of the Commission's approach.

There is also a section devoted to bands. It implies that parading bodies should be concerned about band behaviour in that " $[t]$ heir standards of dress, performance, music and behaviour have the potential to enhance or diminish the public's perception of the organisation...It will be important, therefore, to establish and enforce high standards with bands at the outset...”. Parade organisers are responsible for ensuring band members are aware of and comply with any restrictions on music. 
Stewards are seen as important governing agents at events and parade organisers are responsible for having "a sufficient number of trained stewards". The Code details how such individuals are to be deployed at parades (e.g. some in static positions along the route, while some should be mobile), including what they should know (first aid, crowd management, the Public Order legislation, etc.).

All of the above considerations are said to be about "good preparation" which will "help ensure a successful event". These considerations aim to re-assemble how parading is done prior to the actual event. They work to change the very way parading has been undertaken as an activity by parade organisers. No longer is it acceptable to organise a parade route simply based on considerations of 'tradition'. No longer is it acceptable to organise a parade without taking into consideration the factors in the Code of Conduct.

The next important aspect of the Code of Conduct is its appendices A and B. Appendix A covers 'General Behaviour for Anyone Participating in Parades', while Appendix B covers 'Behaviour in the Vicinity of Sensitive Locations'. I will deal with each in turn.

\section{Appendix A: "General Behaviour for Anyone Participating in Parades"}

The Appendix sets standards for elements listed as: behaviour, dress, alcohol, music, flags, and stewards. These are said to represent "guidance" for participants which should be observed in addition to any conditions agreed upon or imposed. Much of the appendix works to constitute what counts as acceptable and unacceptable modes of expression. Regarding behaviour, all participants in parades must:

*behave with due regard for the rights, traditions and feelings of others in the vicinity, *avoid words or behaviour which could reasonably be perceived as provocative, threatening, abusive, insulting or lewd, *obey the lawful directions of parade organisers and stewards at all times, from assembly to dispersal, 
*abide by the conditions of this Code of Conduct,

*comply with police directions and in accordance with legislation.

It is evident that specifying problematic modes of behaviour is difficult. The first two prescriptions are vague and imprecise. They rely on common sense knowledge and on "the reasonable individual" as to what counts as having 'due regard' for the rights, traditions and feelings of others, and what counts as behaviour that could 'reasonably' be perceived as provocative etc.

Regarding dress, "paramilitary-style clothing or regalia, including emblems or insignia of a paramilitary or proscribed organization" are not to be worn or displayed at any time during a parade. Alcohol is problematized in that it is not to be consumed prior to or during a parade. Music is to be restricted when in the vicinity of 'sensitive locations'. It is recognized that flags may have legitimate historical significance, but they are deemed unacceptable when relating to a proscribed organization.

Again, the appendix places much responsibility on parade organisers. Organisers must ensure stewards are prepared to identify people who commit an offence; organisers must cooperate with police; they must ensure compliance with police regarding parade dispersal; and they must ensure all participants are informed of any conditions imposed.

\section{Appendix B: "Behavior in the Vicinity of Sensitive Locations"}

What exactly constitutes 'sensitive locations' is not explicitly explained, but rather relies on the common understanding that the following three locations count as 'sensitive':

\section{A. Places of Worship}

*Hymn tunes only to be played.

*When church services are taking place, no music will be played.

*No irreverent behaviour.

*Marching should be dignified.

B. War Memorials or Cemeteries

*Hymn tunes only should be played

*Behaviour should be respectful 
*Marching should be dignified.

C. Where the Majority Population of the Vicinity are of a different tradition, and in Interface Areas *Behaviour should be respectful

*There should be no excessively loud drumming.

*Conduct, words or music likely to cause offence or sectarian antagonism are prohibited.

*Marching should be dignified.

Identifying places of worship, memorials or cemeteries, and interface areas as 'sensitive' locations works to constitute the space of parading in a new way: once coded as 'sensitive', then in these locations, certain words and manner of speaking, behaviour, modes of marching, music playing, and drum playing are also rendered problematic and in need of regulation.

Hymn tunes are deemed a legitimate, a respectful kind of music appropriate for places of worship and war memorials, seemingly as opposed to louder 'party' tunes or 'blood and thunder' tunes. Loud drumming is problematized as inappropriate in locations predominantly populated by those from another tradition. In this, 'excessively loud drumming' is constituted as 'disrespectful' or an otherwise inappropriate manner of expression. The mode of marching in all 'sensitive' locations must be 'dignified'. Again, these prescriptions are significantly vague and unspecified as to what precisely constitutes 'respectful' behaviour, 'dignified' marching, 'provocative' or 'offensive' conduct.

The Code of Conduct addresses the problems that were articulated about parading in the North Report. As a result, the Code embodies different, but overlapping, assumptions about parades. Some points speak to parades as disorderly events, while others speak to parades as symbolic expressions. Parades are imagined both as rowdy gatherings, potentially leading to general disorder and/or politically-related violence (undignified or disrespectful 
marching, excessively loud drumming, signing sectarian songs, use of alcohol). ${ }^{35}$ Parades are also imagined as expressions of cultural identity that have the potential to inflame emotions in the local community leading to disorder (in this, certain considerations must be taken regarding the route, the timing of the parade, parading in 'sensitive' locations, the use of certain flags etc.). Parades were governed as both symbolic displays and as disorderly events. In either case, parades as a whole were not figured as 'the problem' and subsequently banned, rather, it was the participants that must be governed - governed in their relations with others, in their behaviour and manner of marching, in the route traveled, and in their use of particular signifiers in particular locations.

In practice, it would seem that the Code was not very useful (and it certainly did not have the intended normalizing effect). As will be seen in the final chapter of the thesis, the Orange Order rejected the Code as patronizing and idealistic. The Order had their own Code of Conduct, which in their view, was primary. Much of the Code's language was too vague for police to enforce at events and breaches were difficult to prosecute. As a result, in the context of struggle between two groups, the Code did not carry much weight. For the most part, the Code was used more as a tactic by each group to police the conduct of the other at events. For instance, at one parade I attended, a Catholic resident approached the AO I was with and indignantly exclaimed: “don't tell me that was a hymn tune!”.

\section{Conclusion}

This chapter has addressed the establishment of the Parades Commission and provided an overview of its procedures, which may be understood as part of an assemblage; an ensemble

\footnotetext{
35 Bryan (2000) argues that Orange Order parades have lost 'respectability' and become rowdier events (more young people drinking, urinating in the street, leaving bottles and garbage behind, and causing general ruckus). Part of this is attributed to the rise in band culture and increase in band parades. Interestingly, this might not mean that parades have become more sectarian, but they have become more 'disorderly'.
} 
of heterogeneous parts working in relation to each other to 'capture' the space of parading. I discussed how the Parades Commission's administrative procedures worked to produce the central object of government, 'contentious parades'. The information gathering forms, 11/1 and $11 / 4$, allowed for parades to be sorted and invested as actionable objects. Those designated contentious were subject to further regulatory procedures. All parades, however, were subject to the Code of Conduct. The Code was a tool, albeit not a very successful one, used by the Commission to attempt to re-establish (re-frame or re-invest) the norms of parading. The following chapter deals with the next step in the administration process once parades were flagged as contentious: mediation. 


\section{Chapter Four \\ 'The Art of Mediation': Mediation as a Strategy of Government \\ Introduction}

Once a parade was deemed contentious, the Parades Commission worked to achieve a 'local accommodation' where parties in conflict would come to their own resolution on the dispute. As previously noted, a local accommodation was seen as 'outside' power in that it did not involve direct intervention by any governing body. However, a local accommodation was not devoid of power - rather the opposite was the case - in so far as achieving a 'local accommodation' meant fostering and inciting the self-interest of parties in conflict to act in ways that aligned with the aims of authority - the attempt to foster a local accommodation was a technique of power, one where power in the usual sense (direct intervention) was rendered invisible. Much like the drive for consensus on governing procedures more generally, an accommodation ultimately meant there was consensus between parties on the best way forward; and it is through that very consensus that government may operate. Fostering, inciting, and creating self-governing subjects was the ultimate aim of the new governmental approach, and the Commission deployed a central technique towards this end - mediation.

The Commission adopted the following definition of mediation (from the influential report Mediation in Practice, Kelly 1998): “efforts to improve communication between parties in a dispute in a sincere search for a voluntary arrangement that accommodates the relevant interests of all involved". Accordingly, in the first year of operation, the Commission "sought to develop a capacity for mediatory intervention in the community in two ways" (PC Annual Report 1999: 12). First, it provided financial support for the Mediation Network for Northern Ireland (MNNI) in order for it to improve and expand. Second, Authorised Officers (AOs) were hired on contract from the MNNI to work for the PC. The deployment 
of AOs was the primary tactic designed to foster 'self-government' through bringing about a local accommodation. In the First Annual Report (AR), AOs were said to be responsible for: i. gathering information about parades and the areas in which they are held, and reporting to the Commission accordingly;

ii: making contact and building relationships with local groups and individuals, including parade organisers and residents' associations;

iii: helping the Commission communicate with specified parties by disseminating information from the Commission, including, where appropriate, serving determinations in respect of particular parades;

iv: taking steps to secure local accommodation in relation to parades disputes; and

v: reporting to the Commission on the potential for achieving such accommodation. (PC AR 1999: 12-13)

From a governmentality perspective, AOs played a crucial role both in, 'governing at a distance' with the aim of bringing about a local accommodation, and in producing and transferring knowledge of the sites of parading to the PC, including the state of 'community relations'. In that Authorised Officers worked on the ground across Northern Ireland, they were the main link between the centralized governing body and the field of intervention; that is, the spaces where parading took place.

The rest of this chapter discusses mediation as strategy of government, one designed to transform 'problem' relations into relations deemed 'healthy' or otherwise appropriate in the context of a pluralist democratic society. I first discuss the development of mediation in Northern Ireland, followed by an examination of what 'the art of mediation' was deemed to consist. How was mediation to be accomplished? What kind of relationships were to be fostered? I argue that the deployment of mediation brought forth a set of practical knowledges which worked to constitute the space of parading as a governable domain. Central to the discourse of mediation was the notion of 'engagement'. In the last section of 
the chapter, I turn to the Parades Commission and discuss how the body sought to encourage mediation and 'genuine engagement' between parties in parade disputes.

Mediation is usefully thought of as a 'frame' (Callon 1998). “A situation becomes calculable, according to Callon, when it has become framed” (Barry 2002: 272). Thinking, assessing, and managing parading was to occur partly through the frame of 'mediation'. However, in the context of Northern Ireland politics, many aspects of parading trouble the frame (or exist outside of it as 'externalities' in Callon's terms). When such aspects are not taken into account in the original calculation, 'overflow' is the norm. The discussion reveals the difficulty framing parading practices through mediation in Northern Ireland, and it illustrates the ways in which governing bodies sought to deal with and make adjustments to the frame to account for the local political environment and the politics of parading. Perhaps it is more accurate to say that mediation was an attempt to 'reframe' the already existing frame through which parading and political relations in Northern Ireland operated.

\section{The development of mediation as a governing strategy in Northern Ireland}

In the mid-1990s, when the North Report recommended mediation as a central means of addressing parades disputes, mediation was not a widely used strategy in Northern Ireland for resolving conflict. With the rise of the peace process and the decline of outright violence, there was now a greater space in the political and governmental imagination for the use of mediation, generally understood as third party intervention in disputes and a way to resolve disputes through dialogue.

At the time of the parades crisis in the mid-90s, the Mediation Network for Northern Ireland (MNNI) was the primary organization devoted to mediation. The organization was formed in 1991, only a few years before the parades issue arose. The MNNI was formed by a group of individuals who were involved in delivering mediation 
training since 1986. In 1997, the MNNI was still a small organization. There was a director, Brendan McAllister (who began in 1992), two other mediators, an administrator and two full-time volunteers from the Mennonite Church (USA). In addition, the MNNI contracted ten sessional workers, as paid trainers or volunteer mediators, and provided support and guidance to about fifty 'practitioners' across Northern Ireland (McAllister 1998: 15).

With the increase in conflict around parades and the commissioning of the Independent Review on Parades and Marches (the North Report), mediation was on the political agenda and was part of early discussions around how best to resolve parade disputes. Scholars Jarman and Bryan wrote about mediation as the best way forward in their early report on Parades and Protests (1996). The Ulster Community Action Network (UCAN) conference in November 1996 invited mediators from the MNNI to give their views on how mediation could help address the 'parades problem'. And in 1996, a major three-phase project was initiated by the Londonderry Rotary Club which "decided to investigate the possibility of promoting the idea of mediation and facilitated dialogue both in Northern Ireland and abroad" (Young 1998: 4). The project was developed in collaboration with the research organization, the Initiative on Conflict Resolution and Ethnicity (INCORE). The aims of the project, titled The Art of Mediation (a nice play on 'the art of governing'), were identified as the following:

1. To bring together relevant and influential people from Northern Ireland and abroad to promote the role of mediation and the contribution it can make to conflict resolution in Northern Ireland and elsewhere.

2. To exchange experiences of mediation in conflict situations at different levels and to assess the transferability of approaches and methods from one level and situation to another.

3. To exchange experiences of political mediation in different countries and to assess their applicability to the situation in Northern Ireland. (Young 1998: 4)

Both the first and last phase of the project consisted of conferences on the topic of mediation, while the second phase called for research on 'mediation in action' in Northern 
Ireland. The first conference was a half day workshop which focused on mediation as a conflict resolution tool for use in Northern Ireland and abroad. The second conference highlighted international perspectives on mediation and included speakers with experience and knowledge of mediation in a number of countries.

The second phase of the project documented the use of mediation in parade disputes during the summer of $1997 .{ }^{36}$ Grainne Kelly primarily conducted the research. Citing Mo Mowlam, who stated that the "best way forward" was through "constructive dialogue, through intermediaries if necessary, to try to reach local agreement", Kelly said that the point of the research was to better understand how such 'constructive dialogue' could be supported and to offer "clarifying guidelines". Parade disputes were understood as a challenge for mediatory processes, as they were seen as "manifestations of a more deep rooted and protracted conflict" (Kelly 1998: 22). Disputes were also seen as linked to one another and to the broader political conflict. The research focused on six case studies of mediation in parades disputes in particular locations. It aimed to highlight what worked, what did not, and how mediation could be improved; in other words, to adjust the frame and account for overflows.

The project resulted in the publication of Mediation in Practice: A Report on the Art of Mediation Project, edited by Grainne Kelly (1998). Through this project and subsequent report, and through the discussion and information gathering on mediation that was ongoing at the time, questions about mediation were being addressed. What was mediation exactly? What was the aim of it? What were the core principles? How ought mediation best be accomplished? What challenges did mediators face in the Northern Ireland context? What

\footnotetext{
${ }^{36}$ In the summer of 1997, as a non-statutory body, the PC was solely to examine existing mediation processes, to identify best practices, and implement proposals for promoting and facilitating mediation.
} 
could be learned from mediation practices in other countries? With the affirmation of mediation in the North Report, the practice of mediation in Northern Ireland was en route to becoming more formalized, standardized, and professionalized, such that mediation could be deployed more systematically in the government of conflict.

While the use of mediation was affirmed in the North Report, mediation was not an entirely new strategy to address conflict over parades. Mediation was undertaken informally, on a case by case basis, by a variety of actors. The MNNI had previously used an 'intermediary approach' in dealing with parade disputes, where a third party acted as a 'go between' for groups who did not meet (McAllister 1998). In addition to the few professional mediators operating in Northern Ireland, other actors also played mediatory roles, such as church leaders, Quaker conciliators (they had a history of 'behind the scenes' mediation at parades), political officials and local business leaders. Individual RUC officers also, on occasion, tried to facilitate a local accommodation between parties in conflict (Kelly 1998).

Mediation or 'intermediation' was generally done to enable a 'deal' or agreement to be made in relation to a particular parade. As Kelly stated "it has been the case that deals brokered at the last minute predominate in parades disputes" (1998: 25). In their 1996 report, Jarman and Bryan also noted how parade disputes were dealt with:

At present disputes over the right to parade are either resolved by the police making decisions according the Public Order (NI) Order 1987, and physically enforcing that decision if necessary, or through intermediaries mediating an agreement or some accommodation between interested parties. Whilst both methods might produce short term answers in particular instances they are unlikely to prove effective in improving the general environment in which public political expression in Northern Ireland takes place. Consequently the problem of the right to parade remains as a blight upon community relations. (Jarman and Bryan 1996: 145-6)

Prior to the North Report and the Parades Commission then, brokering 'deals' case by case (whether done through an intermediary or directly) was an established 'way of doing things'. Brokering a deal usually meant some sort of agreed upon exchange. For example, in 
Bellaghy in the summer of 1997 an agreement was reached through a facilitator and a document was drafted dictating a shortened route, the banner to be carried, the music to be played in the village (hymn tunes only). In exchange, there would be no counter-protest. The document was signed by three people from each side. In Dunloy, also in the summer of 1997, an accommodation was suggested that included three marches in the village, one immediately as a gesture of goodwill, with further parades in July and September. In the future, only two marches per year would be acceptable (Kelly 1998: 38).

The North Report endorsed the formal (organized) use of mediation to resolve parade disputes, but more importantly, mediation was to be used within a new governing program, one where the aim was to foster a longer-term resolution as to how parading ought to take place in locations deemed contentious. The established way of doing things did not involve a long-term view (consideration of the future), or proactive attempts to solve conflicts before they occurred. As pointed out by Jarman and Bryan (1996), with the cyclical pattern of the marching season, there had been no pressure to try to resolve disputes for future years. "All too frequently a 'wait and see' policy has been adopted or determined by actions" (Kelly 1998: 74).

Mediation at the time was also viewed negatively in the public imagination. Jarman and Bryan noted that mediation was 'presently misunderstood': "In part this is due to the unfamiliarity with the idea and in part due to the public way that the Mediation Network for NI were [sic] involved in the dispute at Drumcree" (1996: 116). During the Drumcree dispute in 1995, Brendan McAllister of the Mediation Network was invited by the Assistant Chief Constable to mediate between parties which resulted in a comprise being reached. After the parade, however, there was a sense of victory on the side of Protestants (as though they had 'won'), which caused contention and made the mediation process appear 
problematic. Kelly further explained that the "reputation of mediation has been tarnished some extent as, on occasion, mediation formats have been used in inappropriate situations, such as when parties are involved in the process without the political will for, or interest in a solution, or merely as a public relations ploy" (Kelly 1998: 25). There were even public demonstrations against mediation in the villages of Dromore and Dunloy (Kelly 1998). Such protests are an excellent of example of a form of overflow.

The new governing approach and new context in which mediation was to be deployed had to 'take over' an informal but established way of 'doing' and 'thinking' in relation to disputes, including what was meant by 'mediation' and new associated terms, such as 'genuine engagement' and 'meaningful dialogue'. As the following section aims to show, achieving a longer-term resolution meant mediation was now not only to 'broker a deal' on a case by case basis, but it was to transform relations between groups in conflict. It was to transform relations from ones deemed problematic due to mistrust and misunderstanding, to ones deemed 'healthy', which exhibited 'respect', understanding for the views of others, and a willingness to 'compromise'. Mediation was expressly intended to foster the capacity for groups to resolve disputes among themselves more permanently (through fostering these new kinds of relations). Mediation was a governing tactic - imbued with 'aspirations for the shaping of conduct in the hope of producing certain desired effects and averting certain undesired effects' (Rose 1999: 52).

\section{What was the 'art of mediation'?}

What was the 'art of mediation'? How was it thought to be accomplished? What kind of relationships were to be fostered? From what kind of relationships deemed currently to exist? The deployment of mediation brought forth a set of practical knowledges which worked to constitute the space of parading as a governable domain. Such practical 
knowledges worked to define what was problematic about relations in Northern Ireland and how those relations ought to be worked on or transformed. Such knowledges also worked to define the strategies used by mediators to make such transformation possible. The knowledges and framework of mediation (how it ought to be done, with what aims, what precautions) were brought to bear on the spaces and practices of parading through the deployment of authorised officers.

Ian Young, Chairman of the Londonderry Rotary Club, stated in the Preface to the Mediation in Practice report: "Our overall objective was to address the fact that, when people are not talking to each other, it is necessary that some form of communication be established between the parties, so that the hopes, fears and possible solutions can be communicated to each other" (Young 1998: 5). In its most simple form, mediation was to be about talking encouraging, facilitating, and promoting talking between individuals and groups deemed in conflict. Fostering such 'talking' was the central aim of governing tactics deployed towards parades disputes. The underlying assumption was that talking would, potentially at least, lead to understanding of 'the other' and therefore potential compromise and resolution.

Sue Williams, director of a conflict-based organization in the UK and with extensive experience with mediation in Northern Ireland and internationally, gave a presentation at the Art of Mediation workshop, a half day workshop held at INCORE headquarters in June 1997. Williams discussed mediation as a transition to 'talking' in conflict situations. Mediation also meant a willingness to look for a resolution, which included considering the views of 'the other side'. Her presentation focused on why "opponents need to talk to each other... [t]his is, after all, the most basic issue in mediation. Why talk?”. She stated that the dynamics of conflict do not lend themselves to talking - the dialogue "is all on one's own side, and anyone who does talk in a human way with the other side is likely to be seen as a 
traitor" (Williams 1998: 6). "It is in this context that mediation occurs. Only when a group is prepared to look for a settlement with the other side, instead of or in addition to trying to defeat them, will they consider mediation, negotiation, problem-solving - all processes which expand the frame to include the other side in deciding the outcome. Now there is a need to talk". She explained that the "transition is difficult" as a "willingness to talk to the enemy may be seen as a sign of weakness, a granting of legitimacy, a concession" (Williams 1998: 6).

Brendan McAllister, director of the MNNI, explained in his workshop presentation (the same June 1997 INCORE workshop attended by Sue Williams), that the ideas of Mediation Network were influenced by the ideas of Professor John Paul Lederach of Eastern Mennonite University in Virginia, USA. According to McAllister, mediation has four potential functions:

- To facilitate communication

- To improve understanding

- To support creative thinking

- To explore accommodations

He stated that mediation meant a transition from 'peace-keeping to peace-building'. Peace "is built, gradually, over decades and generations" and central to the concept is "a belief in the fundamental importance of relationships based on respect and dignity" (15). Mediation was said to be a way of "assisting in this task of establishing greater trust and respect" in a divided society (McAllister 1998: 15). McAllister sought to clarify the difference between 'negotiation' and 'mediation', which he said was often confused: 'Negotiation gives primacy to the issues of the conflict. Mediation gives primacy to the relationships. In negotiation the sides set out their demands. In mediation, they express their needs. Negotiation is, perhaps, more efficient. Mediation is, ultimately, more profound" (McAllister 1998: 19). Mediation may be best understood as a technology of peace, in that 'peace' was seen as the ultimate 
aim. 'Peace' is a taken-for-granted term, but a state of living given definition through the governing program.

Mediation may include face-to-face dialogue and intermediation (as discussed above), but it may also include informal behaviours by anyone who intervenes in a conflict as third party. McAllister called this 'mediative behaviours'. He said: 'We resist the tendency to present mediation as something new and imported from abroad. We are simply giving shape to the non-violent impulses of our people and developing a methodology which resonates with their inherent wisdom after a quarter of a century of bitter conflict" (McAllister 1998: 17). Kelly also noted that mediation is a flexible concept and can be and has been done by individuals without it being called 'mediation' as such. The formal deployment of mediation to address parade disputes formalizes and aims to standardize (i.e.: apply to all cases) the informal practices used, at times, by parties in conflict in Northern Ireland.

Mediation aimed to transform relations between groups in conflict through particular strategies, such as doing "trench work", described below. In addition to fostering mutual respect and establishing trust (McAllister 1998: 16-17) the explicit aim of mediation was to shift how parties in conflict viewed and understood each other. "Mediative behaviour" was said to include imparting "a sense of the other" by increasing "awareness of the other's point of view". It included what McAllister called "inclusive thinking”, meaning, "enabling each side to think of the situation in terms which include the needs of the other side". And it included doing "trench work": "in Northern Ireland our society is often polarized, with Catholics and Protestants adopting age-old positions and 'digging in' like soldiers in trench war-fare. Mediators can work effectively by spending time in the various trenches, as outsiders in surroundings populated by only one side" (McAllister 1998: 17). 
The premise for mediation was that relations in Northern Ireland were problematic.

Consistently, social relations were described as lacking in trust and respect, there was a 'climate of suspicion', tension, and feelings of fear and anger between communities. In terms of facilitating mediation, Jarman and Bryan noted (along with others) there were "wider problems of mistrust and a lack of desire to compromise" that must be addressed (1996: 118). As McAllister said above, groups were seen as claiming polarizing positions and being unwilling to shift from them. The North Review conducted an attitude survey and asked respondents about the main causes of disagreements over parades. The pre-given options are telling, as they embody a particular characterization of relations. The answers included: 'Unionist/Loyalist insecurity'; 'Nationalist/Republican impatience'; 'Nationalist/Republican desire to show dominance'; 'Unionist/Loyalist desire to show dominance'. ${ }^{37}$

Of central importance to the operation of the Parades Commission and its use of mediation was local participation in the governing process. Harnessing 'the local' was the key to the new governing strategy deployed towards parade disputes. 'Local communities' were to be enrolled in their own governance. Kelly stated it was most important that "those local to an area or dispute have the most significant input in discussions and decisions relating to the parades". Further: "Although we are aware that outside influences are often at play, we feel that the solving of disputes to the satisfaction of the local communities is the central tenet which must be emphasized" (Kelly 1998: 74). It was believed that agreements reached locally were longer lasting and more likely to work (Kelly 1998). Jarman and Bryan (1996) also suggested that imposed decisions do not work. Such an approach embodies the central

\footnotetext{
${ }^{37}$ Other pre-given answers included: 'Too many parades'; 'Unionist/Loyalist genuine fear of losing ground'; and 'Nationalist/Republican genuine fear of marches' (North 1997: 239). In 1999, the Parades Commission commissioned a survey on public attitudes towards it and parades, and asked the same question, with the same pre-given answers, with the addition of 'changes in the religious mix of areas' (Research \& Evaluation Services 1999: 29).
} 
characteristic of liberal governmentality: government through freedom. Harnessing local participation was one of the central challenges faced by the Parades Commission.

\section{Encouraging mediation}

In the Mediation in Practice report, Kelly wrote a series of 'guidelines' based on her research on mediation in parade disputes. These were guidelines designed to 'guide' mediation efforts specifically in relation to parades. Kelly opened the section by stating: “The most obvious question to ask: How do you encourage mediation?” (1998: 73). The willingness or desire to enter into mediation was seen as something that had to be fostered. The aim of mediation efforts at the time was "to promote a belief that the process may be a positive step in opening lines of communication, increasing mutual understanding and working towards resolution of a dispute" (Kelly 1998: 73). Belief in the process needed to be encouraged in order to entice parties to engage in mediation in the first place.

Such encouragement was designed to work on those who desired a resolution, but were distrusting of the mediation process. Those who were seen as unwilling to compromise and seen as lacking desire to achieve resolution in the first place were worked on through various governing strategies (largely discursive) deployed to encourage groups to compromise, some of which were seen in chapter two: reframing the argument away from a winner/loser (and tradition vs. consent) narrative to one centered on the fair balancing of rights; shifting the perception that giving up something (such as the desired route) in one particular parade, meant a loss of ground, or that the concession would be permanent; offering the 'moral high ground' to those that compromised or voluntarily re-routed; inciting responsibility for the state of the wider peace process, the state of the economy, investment in Northern Ireland and tourism, along with the perception of Northern Ireland to the rest of the world. At times, groups were seen as ungovernable, meaning totally uncompromising 
and impossible to work with in terms of finding a local accommodation. These groups, generally seen to be on the more extreme end of the political spectrum, were left out of governing attempts, which generally focused on individuals and groups deemed 'reasonable'.

Such encouragement was also needed because it was believed that mediation had to be entered into voluntarily. "Throughout this research a strong theme pervaded: mediation should be facilitated, never imposed by any outside authority or body" (Kelly 1998: 73). The idea that mediation could not be imposed was widely held. Sue Williams (1998) (referenced earlier) referred to a 'willingness to talk' and Jarman and Bryan stated that groups 'must be willing and desirous of finding a compromise" (1996: 116). Kelly's report goes on to explain that there are "a number of important reasons why mediation should not become a compulsory exercise”. Kelly stated that the desire to find an accommodation must be genuine: "A willingness to come to an accommodation must exist on both sides, otherwise the process is of little benefit". Mediation was to be about transforming relationships: "Simply put, voluntary processes hold more scope for meaningful relationship building, as the willingness to enter into the process is already present" (Kelly 1998: 73). Fostering 'willingness' is about subjection or internal transformation and the constitution of a particular type of 'free' subject.

The idea of mediation shifted the responsibility for managing conflict from the state to the parties who were in conflict. The British state has, historically, been seen to assume control of violence in Northern Ireland by force or law. ${ }^{38}$ Kelly wrote that since the North Report in January 1997, “a strong fear has existed that opposing sides may be forced into a rigid process, whereby entry into a mediated communication exercise would become obligatory, and any refusal would be negatively viewed in an adjudicatory process" (1998:

\footnotetext{
${ }^{38}$ See Ní Aoláin (2000) on the various strategies used by the British state to manage political violence.
} 
73). Mediation required fostering subjects who desired 'genuine' resolution, who had the will to compromise, and the capacity to resolve disputes seemingly 'on their own', rather than rely on a state-imposed solution. Given that the framework and knowledges of mediation dictated it could not be forced or imposed through more coercive tactics, it had to be deployed through more subtle strategies of government.

Mediation was encouraged through a variety of tactics. In early documents around how to resolve parade disputes, mediation was presented as a way to keep some control over one's own affairs (coming from Dominic Bryan and others). Mediation was presented as better than having legal rules imposed 'from the outside' (or 'top-down'): “The repercussions of a lack of community agreement is that decisions would have to be imposed from above" (Jarman and Bryan 1996: 130). The argument put to unionists, the group most hesitant to engage in dialogue or mediation, was 'resolve things on your own before it is imposed on you' (UCAN 1996; Jarman and Bryan 1996).

Mediators themselves were to encourage mediation through particular strategies. Developing a good rapport and fostering trusting relationships with parties in conflict was seen as central to mediation attempts. Kelly pointed out that mediators in parade disputes ought to have the 'trust of the community' and perception of clout or authority. Individuals from the business community were seen as good mediators since they had a vested interest, and were perceived as 'neutral'. Kelly stated: “Their involvement in facilitation and actual mediation appears helpful in that it widens the agenda and ensures a wider voice is heard as both sides come to realize the economic consequences of their actions" (1998: 28). McAllister pointed to the usefulness of tacit knowledge to develop relationships with parties in conflict. He noted, given that each side is normally suspicious of 'outsiders', "[w]e find it helpful to work in pairs, one Catholic and one Protestant, and utilise our respective 'tribal' 
instincts to establish and maintain a rapport with each side" (McAllister 1998: 17). Such are all ways governing bodies worked to adapt mediation to the local context in order to reframe modes of thinking and doing in relation to parade disputes.

Education (society-wide) about parades disputes and the process of mediation was also seen as important. McAllister stated:

In a sense, those in dispute - the actors in the conflict - are surrogates, acting out a conflict which ultimately involves all of our wider society. Therefore, at times it is necessary to address that wider audience about disputes which have societal significance. In addition, there is an on-going 'mission to explain'; a need to educate our society about the concept of mediation as a process. (McAllister 1998: 21)

Kelly stated that there still lacks a basic understanding of the positions and realities of other parties to a dispute and that education means to "increase mutual understanding between groups in conflict" (1998: 76). Education was seen as important to clear up misperceptions of 'the other side' and of mediation itself.

It was further suggested that the language used by mediators be adapted to elicit engagement in mediation processes. McAllister noted that the language of mediation was relatively new in Northern Ireland and therefore suggested that practitioners adjust the way they speak about mediation. He said that "until mediation becomes more widely respected and becomes more credible in the life of our society, its theories remain abstractions and aspirations. There is, therefore, a need for a 'middle language' - for mediators to speak the language of ordinary people but also to include some vision and creativity in their words" (McAllister 1998: 18). Mediators, in a sense, were to bridge the gap between the ideals of governors and the perceived realities of the lives of those in conflict. They were to infuse those everyday realities with a new vision for community relations, one which aligned with the aims of governing bodies. 
In another example of a form of overflow, there were challenges around language use in the context of Northern Ireland politics. Governing discourses could potentially be colonized by 'one side' of the conflict, effectively de-activating the governing attempt: "The jargon of Conflict Resolution, if adopted by one side, can become colonized by them so that ideas about Conflict Resolution can be viewed as part of the ideology of one side" (McAllister 1998: 17-18). For example, when a (Catholic) residents' group calls for mediation with a Protestant marching Order, mediation can appear like 'a nationalist demand'. McAllister also noted that words mean different things to different groups. For example, 'consent' for Catholics means 'respect', while for many Protestants, consent implied 'permission'. 'Parity of Esteem', a term used by Catholics, was seen as intending to discriminate against the Protestant majority. He noted that the word 'compromise' was “looked on with universal suspicion” (McAllister 1998: 18).

Kelly made a similar point about language use. She noted that certain words can "ruin delicate relationship building processes". "One of the challenges of the mediator is to use words which have not been hijacked by one side or another ... It is not uncommon for words to be used by those in disputes as a 'tactic' in order to provoke a certain reaction ... It is not only the verbs and adjectives that have been troublesome but the nouns used to describe certain aspects of the dispute, all of which mediators should be aware of' (Kelly 1998: 70). Finally: “As the term 'mediation' has had its meaning distorted, changed or misconstrued it has become a challenge to all involved to recapture the word so that it appears simply as a process of third party assistance, not something which is perceived to have a hidden meaning or agenda" (Kelly 1998: 71). Governing bodies had to foster a new understanding of the word 'mediation' in order to frame parading practices and politics. 


\section{The Parades Commission, mediation and governing 'genuine engagement'}

Central to the governing discourse of mediation was the notion of 'engagement'. Early on, the Parades Commission stressed that parties in disputes ought to demonstrate a willingness to 'engage' with each other in order to reach some resolution. One of the early strategies designed to encourage entry into mediation took a disciplinary form: during the first year of making determinations (1998), parades were restricted expressly on the basis of a lack of dialogue or 'engagement' with those opposed to parades. Parade organisations were effectively penalized for failing to meet Commission expectations that they work towards finding a local agreement.

The other strategy used in conjunction with making restrictions, was discursive. In the First Annual Report (PC 1999), the Commission summarized its views on parading in each location, including the kinds of determinations that were made, and why such restrictions were seen as necessary. The summaries must not be understood as benign descriptions of parading in these locations, but rather as instances of government. As with the imposition of parade restrictions, statements were designed to incite particular forms of action. Statements were imbued with moralizing judgements on conduct and prescriptions for action. Incitements came in the form of what the Commission 'hopes', 'expects', what it found 'regrettable', where it gave praise, such as recognising 'responsible' conduct, or where it expressed 'disappointment'. The early Commission worked to govern conduct through a mix of repression (restrictions) and incitements.

The following are examples of location summaries as they appeared in the First Annual Report (AR) (1999). The statements made in relation to the Ormeau Road area in Belfast are typical of statements made for most locations: "The PC has recognised the responsible approach of the loyal orders in re-routing their parades away from the Lower 
Ormeau Road. It very much hopes to see clear evidence of genuine efforts by the loyal orders to address the legitimate concerns of others... The Commission expects that such efforts will be recognised and reciprocated" (PC AR 1999: 28).

In Ballycastle, the band organisation was praised for its willingness to engage in dialogue. As a result of this behaviour, the PC believed groups in Ballycastle had the potential to manage parades successfully in the future:

- The band parade organized each year by the Silver Plains Flute Band, Moyarget, has had a consistent history of trouble associated with it, including sectarian and provocative behaviour, and is the subject of cross-community opposition.

- The band has, however, shown a willingness to engage in dialogue through its representatives and demonstrated acceptance of the Commission's determination which was unfavorable to it.

- The Commission believes, therefore, that given a positive and imaginative approach on all sides, the potential exists for an agreement which would ensure an acceptable arrangement for future parades. (PC 1999: 26; my emphasis).

The Annual Report summaries made clear that the power to make determinations was only exercised when those involved failed to find their own solution. In the larger framework of government, sovereign forms of power were justified only when other forms, such as self-government, failed. The governing body imagined itself as reluctant to intervene in 'local' affairs. It was always the case that the PC "had to" impose conditions. For example: Armagh:

- Loyal order parades in 1998 involving contentious areas were notified. Because no solution was found at the local level, the PC had to impose conditions directing the parades away from the Shambles area. (PC AR 1999: 26; my emphasis)

Castlewellan:

- The Commission had to issue determinations in respect of the two contentious parades in Castelwellan in 1998.

- The Commission hopes that the local community can reach a solution which will make its intervention in 1999 unnecessary. (PC AR 1999: 29; my emphasis) 


\section{Londonderry:}

- The Commission had hoped that the understanding in relation to the 8 August parade, which the Apprentice Boys and the Bogside Residents Group achieved through mediated dialogue, would set a precedent for future parades.

- It was therefore disappointing to note the subsequent failure to reach a similar agreement over the Lundy Day parades on 12 December, which necessitated the imposition of conditions by the Commission. (PC AR 1999: 33; my emphasis)

The Commission made it explicit that parades were restricted, not only due to a lack of finding a 'local agreement', but also due to a lack of 'engagement'. Further, in the absence of dialogue leading up to one parade, the Commission suggested that future parades in the area may be restricted or not allowed altogether. In relation to the Dunloy Apprentice Boys Church Parade on Sunday May 17 1998, the PC 'stressed' several points, one of which was: "Our expectations that the Loyal Orders will take immediate steps to engage with the local community in an effort to establish sufficient consensus, without which engagement we can not foresee any further parades in Dunloy in 1998" (PC on Dunloy 1998). In relation to Newtownbutler, the Annual Report stated: "It is regrettable, therefore, that the loyal orders subsequently failed to build upon earlier dialogue with residents... In the absence of any dialogue, the Commission also imposed route restrictions on the subsidiary procession on 8 August" (PC AR 1999: 35).

In general, statements positively recognised when there was effort at engagement and dialogue, when there was 'good' behaviour, and when parades were voluntarily re-routed. Parade organisations were rewarded for such self-governing conduct by the PC decision not to impose conditions. The reward was the 'freedom' to march as proposed:

Keady:

- The Commission had noted that those taking part in loyal order parades has been well behaved; the organizing Orange lodge had previously voluntarily re-routed its parade. The Commission, therefore, decided not to impose any conditions on the annual Orange church parade. 
- The Commission hopes that the local Orange lodges would build on the goodwill they created last year in voluntarily re-routing their parade... . (PC AR 1999: 32)

Where there was considered to be the potential for it, the Commission encouraged all parties involved to work towards a local accommodation in the next marching season. The hope was to avoid future PC intervention. In 1998 determinations, then, the Commission stressed the need for dialogue and 'engagement' and, in many cases, used restrictions on parades to incite future compliance.

However, at the same time, internally, the Commission questioned its use of the term 'engagement', partly in anticipation of legal challenges from the Loyal Orders: What did the Commission mean by 'genuine engagement'? What were its expectations? What message did the Commission want to send? With a view of the need for consistency and transparency in its decision-making, the Commission sought clarity on how to define and assess whether 'genuine engagement' had taken place. It also faced the challenge of how to incite a 'willingness' on the part of participants to 'genuinely engage' with each other, in order to foster a local agreement.

Governing 'genuine engagement': Reflexive government and the development of standards

The notion that government advances through processes of reflection on itself is captured in the idea of 'reflexive government', a term developed in the governmentality literature by Mitchell Dean (2010). Government continuously questions its own practices and procedures, and it is through this process that governing transforms. As a new body, the Parades Commission spent considerable time reflecting on its means of rule. One such example is with the Commission's work on the issue of 'engagement'. The topic of 'engagement' was discussed during a weekend-long meeting arranged by the PC secretariat, held in September or early October 1998 (exact date unknown). The purpose of the meeting was to discuss a 
range of issues facing the Commission after its first summer adjudicating parades. The PC produced a twenty-one page report summarizing the key 'outcomes' of the meeting, called the 'Belle Isle weekend'. ${ }^{39}$ The report was directed to PC members and staff. The report noted that "the weekend away proved valuable, not so much for resolving issues as for identifying those issues which require a great deal more work to develop a clear Commission line on them" (PC Belle Isle 1998). In attendance (based on what I can infer) were Parades Commission members and secretariat, academic Dominic Bryan, and members of the Mediation Network.

How the Commission used the term 'engagement' was central to the meeting. Two members of the Parades Commission each wrote papers with the aim of clarifying the meaning of 'engagement'. ${ }^{40}$ I will address each one in turn and, for clarity sake, refer to these documents as 'the first paper' and the 'second paper'. In the first paper, the problem of engagement was expressed as a lack of clear 'expectations' on the part of the Commission. It listed examples from 1998 determinations where the terminology used was inconsistent, the message different, and the expectations of each party unclear. The paper states that "[c]lear guidance from [the] PC is necessary so that parties know what is expected to ensure 'favourable' determinations" and "PC members MUST ALL agree the meaning of phraseology used in documents and agree a consistent message" (PC Belle Isle 1998; emphasis in original).

The discussion around the notion of 'engagement' marks an important moment in the government of parades. The problem of how to define and measure 'engagement' was part of a larger problem of government; that is, the need to set clear standards and expectations for conduct, and the need for transparency and consistency. In outlining its

\footnotetext{
39 Unpublished document.

${ }^{40}$ The papers were annexed to the PC Belle Isle Outcomes report.
} 
recommendations for new procedures, the North Report (1997) stressed that "the structure for and process of adjudication of disputes over individual parades should be clear and applied consistently with as much openness as possible". It recommended the creation of an independent body that would "itself come to a view on what, if any, conditions should be imposed on contentious parades after an appropriately transparent process of examination of all the relevant issues against the background of reformed legal provisions" (North Report 1997: 205). Standards for conduct were not pre-determined; rather, they needed to be devised. Devising standards is a way in which the field and politics of parading was turned into a knowable and governable object. In their book, Calculating the Social: Standards and the Reconfiguration of Governing, Vaughan Higgins and Wendy Larner write:

For governmentality scholars, standards are conceptualized as 'technologies' for the governing of conduct. Technologies may be defined assemblages 'of forms of practical knowledge ... traversed and transacted by aspirations to achieve certain outcomes in terms of the conduct of the governed' (Rose, 1999, p. 52). As such, technologies do not simply intervene in, and govern, pre-existing social problems or domains. Far from existing as benign and neutral tools for achieving harmonization of existing socio technical practices, standards, according to Miller and O'Leary (1987, p. 239), serve to construct 'a particular field of visibility' which makes social domains knowable and governable. This means that standards, and the forms of expertise and practical knowledge surrounding them, are involved in the constitution of those domains which they seek to govern. (2010: 3-4; my emphasis)

Standards then, are 'technologies' - forms of practical knowledge imbued with aspirations for shaping conduct towards desired ends. The lack of clear standards for the government of parades was a problem faced by the Commission early in its operation; a problem exemplified in the discussion around the notion of 'engagement'.

Despite the confusion around the idea of 'engagement', the first paper suggested that the term "is the best description...to express what... should be our attitude" and that it might be thought of as meaning 'to draw into conversation'. The paper proposed that the term engagement needed to be defined more clearly in terms of what it is and what it is not, 
and then urged the Commission to 'adopt a firm and clear policy which all can easily understand'. The PC's summary report affirmed that providing clearer guidance and more clearly indicating how the "PC would respond in a given set of circumstances... would also serve to eliminate the tedious process on which the Commission had so frequently embarked, of iterative drafting to fine tune the nuances in its decisions". The report stated that "the Commission itself had to establish its own standards before promulgating them to other players, including the RUC, NIO, mediators and of course, communities" (PC Belle Isle 1998). Developing clearer standards would help the Commission to establish a standardized and therefore repeatable formula for making and explaining determinations.

The first paper suggested that 'a policy' or 'fundamental principle' (as it was called it the PC summary report) around engagement could be: "Parade organisers must engage with local communities where a parade is likely to be perceived to be offensive". It then outlined the standard that followed from this principle: "this must mean that the PC WILL restrict a parade from passing through a contentious area if there is no genuine engagement" and equally "it means that where there is genuine engagement the Commission will try to facilitate a parade even in the face of opposition from residents" (PC Belle Isle 1998; emphasis in original).

Evident is a combination of forms of power as such an injunction - 'you must!' embodies a disciplinary logic. While 'you must' is disciplinary, 'you must engage' has a more governmental character. The injunction to 'engage' is not about anatamo-politics: it is not an injunction to hold the body in a certain way (hold your head as so, march to this time, etc.). Rather, engagement, what counts as such, had to be defined and specified. It is not a bodily comportment or action. There is the opportunity to evade, resist and do 'engagement' in a variety of ways. While engagement could be encouraged through potential restrictions, it was 
ultimately to be achieved through the internal transformation of the individual. The desire and will to engage had to be instantiated in the interior of subjects. Further, rather than threaten parade organizers with solely negative consequences as embodied in a disciplinary logic, on offer here was the 'freedom' to march as desired: 'do as we wish, and you shall be free'. Governing through freedom is the central characteristic of liberal governmentality. What did the notion of 'engagement' mean exactly? The term was problematized as vague, potentially understood in different ways by different people, and even the Commission itself was unclear as to its desired meaning. Part of setting standards meant defining the meaning of terms. In order to incite particular conduct, directions for action had to be made clear - desired conduct had to be specified. The paper defined 'genuine engagement' (rather than just 'engagement') as having five essential elements:

- Communication with those who are clearly seen as speaking for or representing interested parties.

- Communication in a manner that shows RESPECT for those parties.

- Communication in a manner that acknowledges EQUALITY.

- Communication in a manner which is designed not simply to explain one's own position but to acknowledge opponents' position.

- Communication that attempts to find a solution rather than to reinforce a solidified position.

It also explained what did not represent 'genuine engagement':

- Communication that is designed to by-pass or exclude interested parties...

- Communication that is designed to avoid an exchange of views and ideas...

- Communication which effectively excludes interested parties from contributing to a resolution.... (PC Belle Isle 1998; emphasis in original)

'Genuine engagement' was therefore defined as a particular form or manner of communication between parties deemed to be in conflict. The adjective, 'genuine', was key to the idea of what kind of communication ought to take place. Up to this point (October 1998), the Commission operated on a tacit understanding of what was meant by 'genuine' and 'engagement'. Now, the Commission worked to put this tacit understanding into 
directives - more than words - but guidelines for the Commission to make clear, as well as to follow when assessing cases.

The above directives embody the aims of government. Specifying 'genuine engagement' worked to constitute 'right knowledge' about how parties in conflict ought to interact and relate to one another. It aimed to displace, re-shape, or transform modes of communicating (or lack thereof) deemed problematic. It aimed to act on or intervene in the ongoing tacit political struggle that occurred at the level of attitudes and modes of relating; ways of thinking about and so treating the 'other'. The 'essential elements' of 'genuine engagement', however, remained vague. What exactly counted as 'showing respect'? How did one demonstrate treating others as equals? How precisely ought one to put these directives into action? The difficultly of specifying explicit conduct was the essence of the challenge involved in governing symbolic politics. The object of government was fluid, intangible, tacit, and ultimately difficult to specify and measure.

The paper concluded by equating a lack of engagement with demonstrating disrespect, and disrespect could be understood potentially to harm 'community relations', a factor the PC was (legally) to consider when making decisions: "We must make clear to all parties that in 1999 we shall consider a refusal to 'engage' as showing disrespect for groups and such disrespect must result in a serious negative impact on relationships within the community - a criterion on which we place a lot of emphasis". The PC summarised this point as: "For the future, therefore, the message was clear. There would be no parades in a hostile environment without engagement, a criterion to which the Commission would attach a particularly high premium" (PC Belle Isle 1998).

Using legal measures to prescribe how engagement must take place was considered the anti-thesis to the governing aim, which ultimately sought to foster a change in social 
relations deemed problematic. The second paper on 'engagement' opened by emphasizing that the problem was one of relationships and therefore could not be directly dealt with through law: "Relationships vary between naked sectarian hatred to genuine fears and suspicions. Distrust rules. Such problems cannot be solved by law”. The paper explained that there was "no statutory definition of engagement or prescribed procedures for engagement", and stressed that the Commission was not saying to marchers "you must fulfill certain procedural steps for engagement that have been laid down/or will be laid down, before we will allow you to march". It stated that such a command was not ideal in any case as it would not help achieve the overall governing objective: "Marchers could offer legalistic minimal compliance with procedures to secure a march. Such grudging legalistic compliance will do nothing to promote community relations or win the confidence of residents" (PC Belle Isle 1998 ). The Commissioner recognized that the desired changes in conduct could not be coerced.

The paper went on to outline what the Commission was saying to marchers. While the PC had no legal authority to demand local accommodation, communication, or the use of mediation facilities, it could and did have 'expectations'. It noted that the PC statutory documents contained four distinct expectations of march organizers:

- To communicate with residents

- To work towards local accommodation

- To take account of relationships with residents and to meet their reasonable concerns.

- To avail of mediation facilities.

The paper paraphrased the Code of Conduct which stated: "Take whatever steps are reasonable to meet residents' concerns. Where it is not possible to reach agreement on self imposed restrictions it will be important to take steps to establish a line of communication aimed at achieving accommodation". The communication did not have to be successful at 
achieving a local accommodation, but that "they must make a genuine attempt". Various avenues for communication were outlined (the 'how to' part of governing). The list ranged from face-to-face dialogue, face-to-face talks with a facilitator, direct talks over the telephone, indirect talks through a facilitator, proximity talks, position papers, to a local forum. The PC summarized the second paper by stating: "The essence of what the Commission was trying to convey was that a genuine attempt to establish a line of communication and address residents' concerns was the pre-requisite, rather than success in so doing. Essentially, the bottom line in each set of circumstances was the question of whether the effort was genuine or not" (PC Belle Isle 1998).

Again, the word 'genuine' here is key. It means that the end of government was not just any kind of communication or "simply a ritual compliance" (PC Belle Isle 1998) - it was about inciting a very particular kind of communication with the aim of improving relationships. The genuineness, the willingness, the sincere desire to resolve a dispute, was constituted as the most important factor or indicator to the Commission that a parade could potentially take place in the manner desired (i.e.: peacefully). The communication did not need to be successful, but a genuine attempt at a local resolution (self-governance) was prioritized. Where there was no genuine effort, it meant greater need for governmental intervention and more restrictive measures.

As argued in Kelly's Mediation in Practice report (1998), 'genuine engagement' was seen as something that had to be incited from 'within', not forced through legal measures. 'Genuine engagement', as it was specified, could not be regulated by law. Rather, it had to be governed in the Foucauldian sense. 'Engagement' had to be encouraged and made desirable; individuals and groups had to be instilled with a desire, a willingness, to 'genuinely engage'. In other words, individuals had to be subjected to new forms of subjectification made 
manifest in external conduct, but ultimately located in the interior of subjects. The PC, as a regulatory body, had to work to instill this desire, and it did this partly by setting standards and expectations for conduct, and then penalizing when those standards and expectations were not met. One of the papers on engagement noted that it would "be valuable to clarify publically...that failure to meet expectations, failure to make genuine attempt to address concerns/failure to show respect will be taken into consideration in making determinations". Earlier in the paper it was stated more clearly: "Through our Guidelines and Code of Conduct we can penalize marchers for failure to work towards local accommodation" (PC Belle Isle 1998).

While many saw the Commission as a mechanism to regulate parades legally, from a governmentality perspective, law was not the primary mode of regulation deployed. Law served to establish the Commission's mandate and overall factors it ought to assess in each case, however, how the Commission pursued its mandate was left up to the Commission itself. Law enabled government in the Foucauldian sense. Law enabled the formation and structure of the Commission, while at the same time enabling the Commission to deploy strategies and tactics of government, such as those which aimed to incite engagement and entry into mediation. The desired aims of government, the conduct and relations to be cultivated, were beyond law (Foucault 1990). Law was deployed as one governing tactic among many, mainly serving to penalize when subjection - or incitements to appropriate conduct - failed.

One of the Commissioner's went on to review the structure of the PC, and, in effect, pointed out ways in which its structure enabled it to govern: It "operates on acquired experience and common sense rather than strictures of prescribed procedures". It "operates on [the] basis of general principles established by [the] Commission". It is "likely to attract 
fewer judicial reviews because of [the] absence of prescribed procedures" and it "allows [for the] exploration of 'respect' without having to check ticked boxes". Essentially, what the Commission did, and how it did it, was not clear. And this very lack of clarity, this vagueness in operating procedures, was seen as an advantage - it allowed the Commission to pursue its governing objectives. As the paper concluded, the Commission "has statutory power to operate its current practice enjoying flexibility. Problems of engagement are too complex to fit any prescribed procedure” (PC Bell Isle 1998).

The process of devising standards and expectations around 'genuine engagement' was partly a governing strategy designed to incite particular conduct, but it was also part of how the governing body mapped the tacit and incoherent space of localized parading politics. It was part of how parading was made knowable and therefore calculable, as the established standards were then used to assess parade disputes. After outlining what counted (and what did not count) as 'genuine engagement', the first paper stated that it would be up to the Commission to decide if "genuine engagement" had taken place, and in doing so, it could consider evidence or advice from Authorised Officers and other facilitators "who have knowledge or expertise relevant to the particular case". At the end the second paper was a chart titled $A$ suggested 'scale of engagement' (See Figure 2). The chart orders attitudes and behaviours on a scale of 1 to 10 , where 1 is 'no engagement' and 10 is 'full engagement'. The elements of the scale draw heavily on the Commissioner's specification of 'genuine engagement' (the list of behaviours and attitudes previously noted), and taken together, appear to measure numerically a party's willingness to resolve a dispute. The scale is a technology of government in that it works further to render the illusive notion of 'genuine engagement' measurable and so actionable. Attitudes, behaviours, and ways of communicating between groups in conflict, were ordered according to the governing vision 
Figure 2 - A suggested 'scale of engagement'

A suggested "scale of engagement"

\begin{tabular}{|c|c|c|c|}
\hline Level & Attitude & Content & Means \\
\hline 1. & $\begin{array}{l}\text { "we are } 100 \% \text { right" } \\
\text { Demonise opponents } \\
\text { "we are united" }\end{array}$ & $\begin{array}{l}\text { "inalienable rights" } \\
\text { Reject Parades Commission } \\
\text { Enforced compliance of PC } \\
\text { nuling by police }\end{array}$ & No communication at all \\
\hline 2. & $\begin{array}{l}\text { Deliberately by-pass } \\
\text { interested parties. }\end{array}$ & Justify own position & $\begin{array}{l}\text { Press releases, radio } \\
\text { interviews }\end{array}$ \\
\hline 3. & $\begin{array}{l}\text { We are generous/Christian - } \\
\text { we are making attempts to } \\
\text { be reasonable. }\end{array}$ & $\begin{array}{l}\text { Propose totally unrealistic } \\
\text { solutions } \\
\text { Resentful compliance with } \\
\text { PC ruling }\end{array}$ & $\begin{array}{l}\text { Written statements inviting no } \\
\text { response }\end{array}$ \\
\hline 4. & $\begin{array}{l}\text { We admit some of our } \\
\text { people are a bit hard-line - } \\
\text { "head bangers" }\end{array}$ & $\begin{array}{l}\text { Acknowledge internal } \\
\text { differences }\end{array}$ & $\begin{array}{l}\text { consultation/listening days } \\
\text { press articles, private position } \\
\text { papers. }\end{array}$ \\
\hline 5. & $\begin{array}{l}\text { The problem might be eased } \\
\text { by outside help. }\end{array}$ & $\begin{array}{l}\text { talks about talks } \\
\text { improving knowledge and } \\
\text { understanding of opponents } \\
\text { Publicly accept PC rulings as } \\
\text { compliance with nule of law }\end{array}$ & $\begin{array}{l}\text { Prepared to communicate via } \\
\text { individual acting as third } \\
\text { party. }\end{array}$ \\
\hline 6. & $\begin{array}{l}\text { Acknowledge some right in } \\
\text { opponents' case }\end{array}$ & $\begin{array}{l}\text { Make minor voluntary } \\
\text { changes e.g. to timing, } \\
\text { music, regalia }\end{array}$ & $\begin{array}{l}\text { Prepared to communicate via } \\
\text { outside organisation or } \\
\text { professional mediators; } \\
\text { proximity talks; public } \\
\text { position papers }\end{array}$ \\
\hline 7. & $\begin{array}{l}\text { Acknowledge that a solution } \\
\text { does require movement on } \\
\text { their part. }\end{array}$ & $\begin{array}{l}\text { make substantial voluntary } \\
\text { changes - possibly including } \\
\text { minor re-routing }\end{array}$ & $\begin{array}{l}\text { Prepared to meet selected } \\
\text { individuals (or other pre- } \\
\text { conditions) from other side } \\
\text { suitably diluted e.g. Forum }\end{array}$ \\
\hline 8. & $\begin{array}{l}\text { Seriously want to solve } \\
\text { problem through costly } \\
\text { accommodation }\end{array}$ & $\begin{array}{l}\text { Propose viable solutions } \\
\text { e.g. voluntary major re- } \\
\text { routing of return route }\end{array}$ & $\begin{array}{l}\text { Prepared to meet any } \\
\text { individuals from other side in } \\
\text { a Forum }\end{array}$ \\
\hline 9. & $\begin{array}{l}\text { Claim to be } 100 \% \text { open to } \\
\text { any suggestions }\end{array}$ & $\begin{array}{l}\text { No agreement but PC ruling } \\
\text { accepted without demur }\end{array}$ & $\begin{array}{l}\text { will meet delegation from } \\
\text { other side; no pre-conditions }\end{array}$ \\
\hline 10. & $\begin{array}{l}\text { Show full respect \& and } \\
\text { treat opponents as equals }\end{array}$ & $\begin{array}{l}\text { Agreement - no trouble or } \\
\text { need for } \mathrm{PC} \text { to intervene }\end{array}$ & $\begin{array}{l}\text { any means, any time, any } \\
\text { where, face-to-face }\end{array}$ \\
\hline
\end{tabular}

Source: Parades Commission. 1998. The Belle Isle Weekend: Outcomes. Unpublished document. 
and translated into numerical form. The scale is a way of investing engagement in statistical forms. It is also a technique of normalization in that it establishes standards for conduct; it defines what counts as 'good' or ideal behaviour and what counts as 'bad' behaviour in need of regulation. The extent to which the scale was used is unknown; however, it is significant in that it represents the development of the governing project.

At the end of the Belle Isle weekend, it was decided that the Commission ought to continue to examine the issue of engagement in order to establish more clearly its own understanding of it before making any announcements to the public. In the First Annual Report (AR) published in April 1999, the Commission stated that it adopted the principle "that direct dialogue represented the best means of exchanging views and demonstrating due respect for others' interests; where such dialogue was problematic, all parties should spare no effort in finding a mutually acceptable form of communication". It also offered a definition of engagement: "Engagement by either party represents a real attempt to address the legitimate concerns of others, and a preparedness to accommodate those concerns, where it is within their power to do so" (PC AR 1999: 20; emphasis in original). It hoped the definition would help clarify the distinction between 'engagement' and 'seeking permission', a point made for the benefit of the Loyal Orders who saw the requirement of 'talking' to residents as effectively needing to ask their permission to march.

By the Second Annual Report (2000), the Commission went into significantly more detail. It stated that "several people and organizations have sought further clarification" on the definition of engagement offered in the first report. Given these requests, and following the advice of the Northern Ireland Office (NIO), the PC used the Second Annual Report to offer "clearer guidance on how we assess any engagement". The report made clear that engagement could not be fulfilled by "compliance with a mechanistic checklist". Further, the 
assessment of engagement had to be flexible: The Commission recognised that what counted as engagement depended "on the area and on the personalities involved". The report noted that what worked in one 'set of circumstances' would vary in another set of circumstances and it would be wrong to be overly prescriptive. Finally, the report indicated that engagement was not just about simple talking; rather, it referred to a particular manner of talking: 'Dialogue alone is not sufficient to demonstrate 'engagement'. Dialogue must be sustained, substantive, and genuine if it is to bear fruit" (PC AR 2000: 16).

To make their assessment process more transparent, the PC went on to list a set of behaviours that counted as "genuine engagement". The guidelines or 'pointers' were in effect 'expectations'. The report states:

In a genuine engagement, each party can be expected to:

- enter the process with no pre-conceived outcomes,

- listen to and try to understand the other's concerns,

- show respect to the other, by taking their concerns seriously,

- be willing to communicate their own legitimate concerns clearly,

- focus on issues that are capable of being addressed by the parties concerned,

- demonstrate a commitment to resolving the problem and addressing legitimate concerns, preferably within a target timetable,

- be represented by people with the authority to speak for the protagonists, and

- demonstrate a willingness to consider some form of third party intervention, such as mediation, if direct dialogue is not possible. (PC AR 2000: 16)

While the report was clear on defining how individuals and groups may behave to demonstrate genuine engagement, it was less precise on how such conduct may be practically assessed. The PC recognized that it could only assess "the extent of any engagement where it [could] assess the quality of the dialogue". It stated that a good picture could be captured by talking to both sides. It preferred that AOs or other independent observers be "invited to monitor the dialogue". The PC may also take into account where needed "published records or other agreed minutes or verbatim reports of meetings" (PC AR 2000: 16). Judging 'engagement' by talking to both sides or monitoring dialogue was understood as a largely 
subjective process by the Commission. 'Engagement' could not be scientifically measured, ${ }^{41}$ but only observed and judged according to certain kinds of knowledges: tacit, commonsense knowledge seen to be held by 'third parties' to disputes, and a certain kind of 'expert' knowledge held by mediators (and so Authorised Officers). Observers external to disputes, whether expert or lay (including the Commissioners themselves), were assumed to have the ability to assess when conduct demonstrated a host of tacit traits, such as 'genuineness', 'willingness', 'commitment', and 'respect'.

\section{Conclusion}

With the parades crisis in the mid-1990s, mediation developed into a more formal and organized strategy of government. Mediation brought forth a set of practical knowledges which worked to constitute the field of parading as a governable domain. Certain forms of relations were deemed problematic, while other modes of relating were claimed to be right, appropriate, and normal. However, there was considerable difficulty framing the spaces and politics of parading through mediation. Governing bodies worked to adjust mediation to suit the Northern Ireland context and to account for overflows. Forms of overflow include the established ways of doing things, the politics of language, an unwillingness to enter into mediation in the first place.

In governing 'engagement', the PC worked to govern relationships deemed to be in conflict, and it did this through practices of subjectification; that is, attempting to foster new subject positions and social relations. The PC aimed to transform relations characterised by mistrust and misunderstanding. It aimed to change what was seen as an unwillingness to compromise (to move from one's own position) for the sake of the greater good. The

\footnotetext{
${ }^{41}$ In the Second Annual Report, the PC recognised that "mediation is not an exact science; that the suitability of a situation for mediation can be considered only on an individual basis; and that the qualitative outcome of third party intervention has to be judged case by case" (2000: 19).
} 
Commission hoped that prescribing specific behaviours would eventually lead to a change in attitude: "It has been said that the Commission can influence behaviour, but cannot change attitudes. But by indicating clearly what behaviours are appropriate the Commission can hope, over time, to create circumstances in which attitudes are more likely to alter" (PC AR 2000: 3).

In making dialogue or 'engagement' between parties the central requirement for parading to take place, the new governing regime set up a system such that it obliged groups in conflict to learn new ways of relating. In order to organize and proceed with a parade in locations deemed contentious, there was now a new process to learn, there were new standards and expectations to understand and follow, and one new central requirement that parties in conflict talk to one another in an attempt to find resolution, such that PC intervention would be unnecessary. Parading in 'contentious locations', in theory, could no longer legally happen without some attempt on the part of organizers to consider and understand the views of 'others' deemed to live in the same space. Later, with the incorporation of the European Convention on Human Rights, making parade restrictions based on whether 'genuine engagement' had taken place was rendered problematic. This is addressed in chapter five, where I discuss how determinations changed with the rise of a human rights discourse. In the following chapter I turn to examine how the Commission went about making determinations, specifically focusing on the knowledge production practices through which parades were governed. 


\section{Chapter Five \\ Making Determinations: Mapping 'Contentious Parades' Through Knowledge Practices}

Knowledge practices - the ways in which knowledge is produced about some object - are central to the exercise of power. Governable objects are not ready-made, or naturally occurring - objects do not exist in a form ready to be regulated. Objects must be produced or constituted and rendered visible to governing bodies in a way that is amendable to administration; that is, produced in a form that makes it possible assess, judge, and act on the object in ways that align with governing objectives. Tracing this process of knowledge production, which often occurs through mundane means (accounting practices, surveys, charts, statistics), is significant for illustrating how objects, which appear natural or taken for granted, come to be known, understood, and specified as such. Documenting the processes and practices of knowledge production reveals the contingent basis on which governing rests. As also implied by the concept of 'investment', governing bodies must do quite a bit of 'work', work which is often rendered invisible, in order to govern.

The production of contentious parades as a governable object is a matter addressed in multiple chapters of this dissertation. As seen in the previous chapter, mediation is a practice of knowledge which worked to constitute parading politics. Mediation provided ideas (a form of 'truth') for what counted as 'healthy' vs. 'problematic' community relations and it provided a framework for shaping relations in ways that aligned with governing objectives. Making determinations was another tactic of the governing programme for when mediation and self-government were seen to fail. In order to make determinations, 'contentious parades' needed to be assessed and made measurable; that is, invested in forms amenable to governmental calculation, transparent assessment, and rationally justified decision-making. 
The Commission's governing documents, the Procedural Rules (or 'PC Rules’ 1998) and Guidelines (1998), are central to how the body administered parades. The Rules outline how the PC was to collect 'evidence' to make decisions about parades, while the Guidelines detail what the body was to consider when making determinations. In these texts, the space of parading was newly imagined and assembled - geographically, materially, and relationally - and the documents indicate how and where the Commission was to intervene in this imagined space. One way to think about the documents is as follows: The Procedural Rules (1998) are primarily about rendering parades knowable, while the Guidelines (1998) act as a governing tool designed to make parades measurable.

Rather than thinking about the parading problem as pre-existing such 'evidencegathering, it is through the very evidence-gathering process that parading was rendered a knowable and calculable object. In this chapter, I begin by discussing the Procedural Rules (1998). The Procedural Rules centered on collecting evidence about parades in particular locations, and the discussion illustrates a conflation between 'contentious parades' and 'contentious locations'. When the Commission was first established, it was seen as necessary for the body to educate itself on issues relevant to parade disputes. The Rules state that Commissioners are to collect information on parades in various locations and form a 'preliminary view' on the outcome of parade determinations in each area. The preliminary view was an early assessment of parades in 'contentious locations' and formed the basis on which determinations could be made.

After reviewing the Procedural Rules, I move to examining the preliminary views taken by the Parades Commission, which were assembled in accordance with the Guidelines document. The preliminary views were not published as such; however, the information gathered was included as part of determination documents for parades in 1998. I examine 
the specific kinds of information collected and deemed relevant for each location when the PC first began gathering 'evidence' to make determinations. Geographical locations were central to how evidence was gathered and I argue that governing parades relied on a particular constitution of space in Northern Ireland. The Commission's work depended on already defined territorial boundaries divided by religious/political grouping, namely, Protestants and Catholics. The discussion also shows how governing is expansive - the field of intervention came to include a broad range of conduct and relations in particular spaces across Northern Ireland now seen as connected to how parades took place.

The final section of this chapter examines other knowledge production processes that went into investing parades which enabled the making of determinations. After the first year in operation, the Commission reasoned that preliminary views were no longer required as the situation in the various locations did not significantly change from year to year. In later years, the Commission relied on a standardized administration process to gather information. I examine this administration process, from the role of Authorised Officers to the reporting on parades. This section relies on informal conversations with members of the Parades Commission secretariat and an Authorised Officer, as well my attendance at a determination meeting in 2011.

\section{The Procedural Rules}

With the advent of the Parades Commission, various knowledges were brought together to produce a new way of governing. The Public Processions (NI) Act 1998 states that the Procedural Rules are to be "for the purpose of regulating and prescribing the practice and procedure to be followed by the Commission and by others in their dealings with the 
Commission" $(4.1)^{42}$ To this end, the document centres on how the Commission will gather 'evidence' on parades in order to come to some decision on how it ought to proceed. ${ }^{43}$ Such knowledge worked to indicate to the Commission where it ought to intervene. Two interrelated factors emerge as important: Past events and the location of the parade. How parading has occurred in the past and is most likely to occur in the future was tied to the location of the event. As such, the Commission targeted the environment in which parading took place, where such space was newly imagined in terms of 'community relations'.

The Procedural Rules state: "In most areas a pattern has emerged of parades held on a regular cycle. Where these are contentious, a corresponding pattern of protest activity has developed. The Parades Commission will therefore examine the situation in those areas in which experience of previous years suggests that disputes are most likely and decide which parades will be considered" (PC Rules 1998: 1.3). Thus, according to the Rules, the Commission determined where governmental intervention was required based on where parades have caused protests in the past. It is 'the situation in those areas' that the Commission was concerned to know, specify, and calculate in order to determine how a parade may proceed. ${ }^{44}$ There is a slippage here between a parade and its location such that

\footnotetext{
${ }^{42}$ Available: http://www.legislation.gov.uk/ukpga/1998/2/contents/enacted. (Accessed September 5 2013).

43 The discussion examines the original Procedural Rules published in 1998. The Procedural Rules were amended in 2005 to take into account the changes made to the Public Processions Act in the same year to include protests under the remit of the Parades Commissions. The 2005 Procedural Rules no longer includes a section indicating that the Commission will take a preliminary view of parades in each location, as this was deemed no longer necessary in 1999. The 2005 document also contains an added section on 'supporting mediation' (section 4).

${ }^{44}$ While visiting the Commission's offices, I was shown a book of maps of areas in Northern Ireland developed by the army. The book is called 'Contentious Locations'. I do not know the extent to which the Commission used these maps. The maps, however, are significant in constituting space in Northern Ireland according to political/religious divisions. Further, maps were brought to determination meetings by police officers to highlight the route of the parade under consideration and to discuss the logistical elements of the policing operation.
} 
governing parades meant governing particular 'problem locations' in Northern Ireland, where a 'problem' manifested itself in the form of protests.

In 1998, the Commission was to begin to gather knowledge of parades in locations deemed contentious by taking a 'preliminary view'. The Rules state:

Commissioners will be allocated to individual locations to consider the available information and form a preliminary view on the outcome [of parade determinations in that area]. These views will be pooled and the Commission will express an informal broad view of what it sees as on overall pattern of parades in contentious areas across Northern Ireland. (PC Rules 1998: 1.4).

With the preliminary view, rather than examine each parade on a case by case basis, parades were to be pooled according to the location in which they took place. ${ }^{45}$

For each parade deemed contentious, information about the parade and location were to be collected. The 'relevant factors' specified are:

i) past parades, together with details of the routes, the number of participants and bands and the past record of conduct of the parade and any related protest;

ii) the demographic mix of the local community both on the parade route and in the immediate vicinity of the parade;

iii) the local area and the key points on the parade routes such as churches and any landmarks of sensitive historic significance. (PC Rules 1998: 2.1)

The Commission worked to gather knowledge on 'community relations' in each location by measuring 'demographics' - code for assessing the balance between Catholics and Protestants in the area. It considered what has happened in the past in each location, and worked to gather knowledge on what were deemed 'sensitive' landmarks in the area. The Commission did not make a new decision with each parade. Rather, it worked continuously to amass knowledge of 'locations' through which to assess the potential for a parade to take

\footnotetext{
45 The preliminary views were never published due to intervention from Tony Blair who feared that the document could derail the wider peace process and influence voting on the Belfast/Good Friday Agreement (see Jarman 1999: 1436). Such intervention raised questions about how readily the government would interfere in the work of the 'independent body'.
} 
place with or without conflict. Once specified by location, the state of 'community relations' was to a certain extent territorialized, and this body of knowledge formed the foundation for making determinations.

As previously noted, Authorised Officers (AOs) acting on behalf of the Commission were to assist in gathering this information. The Procedural Rules state:

Authorised Officers will also have responsibility for making contact and building relationships with local groups including parade organisers and residents' associations and taking steps to secure local accommodation in relation to disputes. They will also report to the Commission on the potential for achieving such accommodation. (2.1)

Commissioners were also to visit the location of a parade and "familiarise themselves with its main features" (PC Rules 1998: 2.1).

Finally, in terms of gathering information, the Commission wished "to hear views on individual parades, or a series of parades in a location, from those most concerned with those parades and also from the significant wider community where parades take place" (PC Rules 1998: 3.1) During the consultation process, the Commission would also "consider fresh advice from the RUC about the extent to which the parade in its proposed form would result in public disorder or damage to property". The Commission would then take "into account all the relevant information, evidence and advice" and a decision would be made by majority vote "whether to issue a legally binding determination imposing conditions on the organisers of the parade" (PC Rules 1998: 5.2).

\section{The preliminary views and determinations in 1998}

From the outset, the Commission has pursued a policy of transparency in explaining the reasons for its decisions on whether to impose conditions on parades. In every location where the Commission has gathered evidence from local people about disputes over parades, it has prepared a comprehensive document which describes the background to the dispute (based on research instigated by the Commission); summarises the views conveyed to the Commission by all parties; and set out how, by taking into account all the relevant factors, it has reached its conclusion. (PC AR 1999: 9) 
The techniques and procedures used to assemble 'evidence' are a central way in which the PC worked to constitute parading politics and the state of 'community relations' in locations deemed contentious. The Commission was to "hear views on individual parades, or a series of parades in a location, from those most concerned with those parades and also from the significant wider community where parades take place" (PC Rules 1998: 3.1). For each location, selected members of the Commission visited the area on a particular date. In order to solicit views, the Commission placed ads in local newspapers. Evidence included oral testimony from members of the public and/or local organizations, along with written evidence from individuals and the police. In the two locations more widely know to be contentious, Portadown and the Ormeau Road, the Commission carried out a more in-depth two-day evidence-gathering exercise (as opposed to one day in other locations).

While certain social scientific information was brought to bear to help diagnose the overall parading problem (such as anthropological knowledge around identity and symbolic displays), ${ }^{46}$ the Parades Commission did not have a scientific means to gather knowledge on parades - there were no statistical formulas, forms of accounting or measurement that could render parading, as a problem of relationships, readily observable. 'Gathering views' was a practical way of constituting the politics of parading; it was a way to bring the tacit and the non-discursive into discourse, or a way to 'seize' the indeterminate in a knowable and governable form. Through such investments, the indeterminate world comes to be seen as ordered. Gathering views was a means to form representations of parades disputes in localities, and such representations provided the foundation on which the PC could make its assessments.

46 Here I have in mind the work of scholars such as Dominic Bryan and Neil Jarman whose initial reports on parading were influential. 
In taking evidence, the PC worked to 'know' parade disputes in line with the factors in the Guidelines: "In our formal hearings of evidence, we asked those who came before us to relate what they were saying to the salient factors outlined in the Commission's Guidelines document. Inevitably, discussions were wide-ranging but we have attempted to give our observations on the evidence as it related to the factors in the Guidelines" (PC on Dunloy 1998: 6). The factors in the Guidelines were an administrative frame through which further to organize the social in particular spaces. Given that 'evidence' was collected and organized according to the factors in the Guidelines, what emerged in the broad views must be understood as a production rather than a presentation of hard facts - an assemblage or performance based on the governmental understanding of the problem at the time. It is through such evidence gathering and assemblage of knowledge that parading was constituted as a domain of government.

The evidence gathered for the preliminary views was documented in generally the same format for each location. The reports opened with a brief summary of how evidence was collected in the location being discussed (which date the Commission was in town, who from the Commission came to the meeting, how many individuals contributed evidence, and any community groups who gave evidence). 'This was followed by the 'background' to parade disputes in the area, which was followed by a detailed outline of parades and protests in recent years. The Commission then outlined the evidence it gathered as it related to each factor in the Guidelines (listing the evidence by factor). The reports ended with a conclusion by the Commission about parade disputes in the location. Analyzing the type of 'evidence' collected by the Parades Commission allows one to trace the process of knowledge production about 'contentious parades'. 


\section{Mapping 'demographics', the route of parades and the history of trouble}

The first main section of the preliminary reports detailed the 'background' to the dispute.

The relative size of the location was noted, such as whether it was a small town, village, or city, as well as where geographically in Northern Ireland the area was situated. Then the 'demographics' of the location were discussed. While 'demographics' might suggest a variety of factors, such as age, class, gender, or occupation, the 'demographics' in this case consistently referred to the division or the perceived division between the numbers of Catholics and Protestants living in the area. Documenting the demographics also included noting where, geographically, members of each group predominated or were seen to predominate. For instance, in relation to Bellaghy, the report stated: "It has a population of 2642 which is estimated to be $80 \%$ Catholic; however the population of the surrounding rural areas is predominantly Protestant” (PC on Bellaghy 1998: 1). ${ }^{47}$ In relation to Armagh city, the report stated: "The city has a strong religious tradition and has both a Roman Catholic Church and a Church of Ireland cathedral. It is not perceived to be a strongly nationalist or highly politicized town, although both the Shambles and Railway Street area are regarded as clearly Catholic/nationalist areas" (PC on Armagh 1998: 1).

Documenting the division or perceived division of space between Protestants and Catholics was central to the constitution of parades as an object of government. The Parades Commission relied on an already formed understanding of population and territory. Curtis' analysis of the census and the concept of population is relevant here. Much in the same way as the idea of population "localizes political subjects in space", so too does the idea of

${ }^{47}$ For clarity in the text, I refer to the 1998 preliminary views and attached determinations by name of the location where the parade was to take place. 
parades when specified as problems of 'community relations'. ${ }^{48}$ Political subjects were located in the spaces of 'the community'. Curtis writes, "[t]he execution of a census of population typically depends on the capacity of state agencies to define territorial boundaries, to subdivide them in convenient ways, and to attach political subjects to such subdivisions" (2001: 25). Similarly, the Commission's governing work depended on already defined territorial boundaries (known 'locations' which were already named cities, towns, villages found on a map), as well as subdivisions defined by the political groups, or one might say, 'imagined communities' (Anderson 1991) which were attached.

Indeed, the overall understanding of the parades problem relied on a constructed notion of population and territorial groupings. Population shifts were deemed the central cause of parade disputes, as such shifts were seen to cause the route of parades to become contentious. The Commission underscored this view (first expressed in the North Report) based on the evidence it gathered in the preliminary views. On the Tour of the North Parade, a particular parade in North Belfast (and the exception to gathering evidence by location), the PC stated:

In common with the vast majority of locations in which loyal order parades have become contentious, the contentious part of the route has seen considerable demographic change over the past 20 years. While the entire route would have previously been considered predominantly Protestant, or at least mixed, most of the contested section would now be deemed nationalist. (PC on Tour of the North 1998: np)

In other words, routes of parades became problematic in relation to perceived demographic shifts. Documenting the route of parades, in relation with imagined sectarian spatial divisions, was a practical means of rendering parades governable. The route was something which could be known, assessed and acted on.

48 The idea of 'parades' itself localizes subjects in space. Parades were understood as events that happen somewhere, in particular places. The concept of parading is spatial. 
In the preliminary views, particular attention was paid to noting issues of contention and 'problem' spots along the route. In reference to Bellaghy, the report stated: "Members of the residents' groups objected to the number of parades in the town and to their proximity to two small estates, Beatrice Villas and Hunter's Park at the northern end of William Street, and to the unwillingness of members of the loyal orders to discuss their concerns" (PC on Bellaghy 1998: 2). If part of the route was deemed contentious, this was noted. For instance, in relation to the Tour of the North: "The relatively small but nonetheless significant section of the route which is deemed contentious begins at the junction of Cliftonpark Avenue and Roe Street and runs through Cliftonville Road, Antrim Road and Duncairn Gardens” (PC Tour of the North 1998: np). In Dunloy (PC 1998), contention was said to centre on the number of parades which passed through the village.

Contentiousness was characterised by the occurrence of objections, complaints, protests, or 'disturbances'. On Dunloy: “The problems over parades in Dunloy began on 12 August 1995 when disturbances broke out between local residents and bandsmen returned from the Apprentice Boys parade in Londonderry" (PC on Dunloy 1998: 2). On Armagh: “There were a small number of protesters against the $12^{\text {th }}$ July parade in 1996 but more significant disputes over loyal order parades in Armagh began in August 1996 when residents staged protests at an Apprentice Boys feeder parade” (PC on Armagh 1998: 2). And on Pomeroy: “The current cycle of disputes began in 1995 when complaints were made after the band parade, but these only escalated after the Drumcree church parade dispute in July 1996” (PC on Pomeroy 1998: 1).

Routes were mapped in terms of both demographics (Protestant, Catholic, or mixed, whether real or perceived), and in terms of contentiousness. Regarding the Tour of the North, 'key sites' were noted along the contested part of the route, such as the Belfast Royal 
Academy, the Jaffa College of Business Studies, and St. John's Church of Ireland and rectory. Commercial properties, as well as bars or 'licensed premises' were noted in terms of their proximity to the parade route and in terms of political/religious affiliation (Catholic or Protestant). 'Interface' areas were pointed out in terms of proximity to the route. Finally, also noted was if the parade route passed close to any sites of politically motivated violence: "The proposed route would also pass close to the Clifton Tavern, the scene of a sectarian attack on 31 December 1997 which resulted in the death of Eamon Trainor" (PC on Tour of the North 1998: np). Beyond being a list of facts, such documentation worked to constitute parading as an object of government by particular mapping practices. On "spatializating the gaze of governors", Nikolas Rose states it well:

To govern, it is necessary to render visible the space over which government is to be exercised. This is not simply a matter of looking; it is a practice by which the space is re-presented in maps, charts, pictures...It is made visible, gridded, marked out...In this process, and from the perspective of its government, salient features are identified and non-salient features rendered invisible. (2004: 36).

Another element documented in the preliminary views was the history of parades and protests in each location and an assessment of when 'trouble' at parades began (at times referring to disputes in the 70 s and $80 \mathrm{~s}$ ). The details of parade disputes became valuable in the context of the new governing regime, where an assessment of 'community relations' and the potential for public disorder, along with the potential for local agreement, needed to be made. To this end, constructing a version of the past was central to rendering parades knowable and calculable. Details noted included the number of parades notified in past years and how many were contentious. Each contentious parade was listed by name, including the organization, band, and purpose of the march.

The details of disputes in 1995, 1996, and 1997 were also reviewed. The types of objections made to a parade were noted, along with any violence which ensued, police 
actions taken to deal with the conflict, the overall timeline of events (whether there was a stand-off for instance), any attempts to reach a compromise, who was involved, and any agreement that was actually reached. ${ }^{49}$ It was also noted when attempts at dialogue were made and when/who refused to engage in such discussion. For instance: "Bellaghy Concerned Residents raised objections to the participation of the local accordion band Bruce's True Blues in the parade. The British Legion refused to engage in discussion with the Bellaghy Concerned Residents over the issue” (PC on Bellaghy 1998: 4-5).

Once the history of recent disputes was outlined, the preliminary views went on to detail the 'evidence' gathered in relation to each factor listed in the Guidelines. Beyond the seemingly factual background information, here it is possible to trace what the PC deemed relevant in order for it to make determinations about parades. The overall analysis illustrates how, through the new processes and practices of government, the exercise of power was significantly broadened from the previous regime where parades were dealt with by police through public order laws. In addition to policing parades, the wider social and political environment - including relations between groups, ways of acting and thinking - was linked to parading and became the field of government.

The Commission's Guidelines (1998) expands on the factors developed in the North Report and listed in the Public Processions Act, which detail what the body is to consider when making determinations. The Guidelines may be understood as a governing tool designed to measure and calculate contentious parades. The human rights framework was used to structure the scope of the Commission's adjudication role. According to the PC's first Chairman, Alistair Graham, the guidelines were made based on the fundamental

\footnotetext{
${ }^{49}$ An agreement might have looked like a brokered deal, such as: The parade would proceed as far as the Orange Hall and then turn around to a dispersal point. The parade would not walk the length of the village and in exchange, there would be no counter-demonstration by residents.
} 
premise of the right to peaceful assembly and freedom of expression, as outlined in the

European Convention on Human Rights. The primary task of the Commission was to assess

claims against this right (PC Guidelines 1998). The five factors the PC was to consider are:

1. Public disorder or damage to property which may result from the procession

2. Disruption to the life of the community

3. Impact of the procession on relationships within the community

4. Compliance with the code of conduct

5. The desirability of allowing a parade which has been customarily held on that route to continue to be allowed to do so. (PC Guidelines 1998: 1.2)

\section{Mapping 'unruly' and sectarian behaviour}

In the preliminary views, the first factor considered was 'public disorder or damage to property which may result from the procession'. The Guidelines state that decisions to allow or not allow a contentious parade to proceed 'can provoke disorder' (2.1). Therefore, the PC will ask the RUC (as still named at the time) for advice on how its decisions will impact public order and this will be a factor considered along with the others. However, in 1998, the Commission also made its own assessment of the potential for disorder based on the evidence it gathered in each location. More than the factual occurrence of public disorder or damage to property, documenting 'public disorder' was equated with documenting the more moral categories of 'unruly behaviour', as well as 'offensive' and 'provocative' conduct. The following are examples drawn from the preliminary views on various locations:

Dunloy: "In the main, what we were told did not point to unruly behaviour on a grand scale by participants in past loyal order parades as they processed through the village". There was a perception that parades were "becoming increasingly provocative in nature"... "we heard allegations that there was insulting behaviour on the part of some participants towards the residents that created a sense of fear and indignation among them". ... "We were also told of disorderly behaviour on the part of some residents...". Such 'disorderly behaviour' led to injuries and damage to property (PC on Dunloy 1998: 6).

Pomeroy: "There was disorder as the police removed protestors from the street while, according to one witness, calling them 'fenian bastards' and it was alleged that Orangemen had pointed their umbrellas 'like rifles' at people in the crowd". The PC concluded that while there was little damage to property, it was "evident that there is serious potential for public 
disorder again in 1998...". Also noted was "trouble as a result of insults shouted at nationalist people...” (PC on Pomeroy 1998: 5).

Tour of the North: "We heard no evidence of bad behaviour on the part of the Orangemen or other participants in the parade. Indeed, we were told of efforts made by the Orangemen to ensure rigorous stewarding of the parade and of the steps taken to control 'hangers on' and prevent them from entering the contentious part of the route" (PC on Tour of the North 1998: np).

In the new regime, governing public disorder enabled the government of 'bad behaviour' in a way that was not possible when parades were dealt with by police. In order to administer parades, now the cause of 'disorder' was to be made known, and a moral/value judgement on conduct was made. More specifically, in explicating the cause of disorder, disorder was now tied to particular groups, whether marchers, supporters, or protestors. Further, 'bad behaviour' was understood as both disorderly conduct and sectarian conduct; the Commission noted both drunkenness and politically motivated behaviour alike:

We heard of incidents in the Ballynafeigh area of abusive sectarian behaviour associated with what was perceived as a proliferation of parades in that area. We were told that on occasion there were paramilitary trappings to some of those parades. Some of those from the Ballynafeigh area who gave evidence drew a link between the parades and an increase in sectarian graffiti and, in particular, the extensive overnight painting of kerbstones red, white and blue in the area in 1996. .... We also heard of drunkenness on the part of parade followers and allegations that they had damaged property.... (PC on the Lower Ormeau Road 1998: 6)

Behaviour became the concern of government in both a wide and narrow sense. In a wide sense, any conduct might be deemed relevant to the potential for public disorder at parades, such as the way sectarian graffiti and painted kerbstones were linked to parading in the above quote. A rise in sectarian graffiti or other identity displays signaled to the Commission problems with 'community relations' and therefore the potential for disorder at events. Behaviour in a more narrow sense was accounted for in another factor, 'compliance with the Code of Conduct', where the PC was to document and judge conduct specifically of those on parade. 


\section{Mapping 'community life'}

The domain of governmental intervention also came to include the wider spaces of the community where parades took place. With the factor 'disruption to the life of the community', 'disruption' was recognized as an 'inevitable feature of processions' (PC Guidelines 1998). The notion that parades inevitably disrupt 'community life' was not thought before under the 'law and order' approach. This is part of the new way parades were specified. 'Disruption' accounts for the practical or logistical implications of a parade and its assessment required the constitution and assessment of daily 'community life'. According to the Guidelines, the factors taken into account when assessing disruption are the duration of the procession and the degree of restriction of freedom of movement by local residents, such as access to shops, public amenities, and places of worship. The notion of 'the community' captured the life of 'non-participants' - such considerations ultimately took the point of view of those living and moving in the same spaces where parades took place, but who did not take part in parades. The impact of parades on the freedom of movement of others and on the local economy was now made to count as part of parading, that is, as part of the object of government. 'Community life' was not considered when parade disputes were addressed as public order problems, while in the new governing regime, disruption to community life provided the justification for governmental intervention. When deciding how much disruption was acceptable, the Commission was to balance this with the meaning and significance of the parade to those involved (PC Guidelines 1998: 3.1). Such balancing was a method of calculation.

Based on my sample of preliminary views, the Commission most commonly pointed to disruption caused by police security measures, such as roadblocks, which restricted the movement of residents through the area. Security measures, once seen as the solution to 
disputes, were now cast as part of the problem. For example, in Dunloy, the PC noted evidence "of disruption caused primarily by what were described as sieges of the village for up to 3 hours by the police in order to provide safe passage for Orange parades... There was a description of hundreds of police in riot gear and police landrovers placed so as to prevent local people reaching Main Street and thereby denying access to shops” (PC on Dunloy 1998: 7). In Armagh:

It was claimed that the passage of parades through the Shambles/Railway Street area caused considerable disruption, with the closure of shops and businesses for days over the year - 'the place is totally closed down'. It was also alleged that during a parade in 1997, an ambulance was prevented from getting through the area due to the... 'unbelievable' security measures in place for the parade. (PC on Armagh 1998: 6)

'Community' was conceptualized as a space where there ought to be the free flow and movement of people from homes, to shops, to hospitals, and churches, and to other places where 'community members' were seen to have a right of access. At the same time, parading was conceptualized as a mobile object with the potential to hinder the freedom of others.

Also made to count was how such disruption made individuals (non-participants) feel, on the premise that such feelings further fuelled disputes over parades and increased tensions in the community. In the case of Pomeroy, the PC noted that the disruption "has clearly aggravated local antipathy towards parades" (PC on Pomeroy 1998: 5). In the case of the Tour of the North, the Commission noted that police action taken to 'seal' off a contentious part of the parade route was "seen by the residents of those areas as an integral element of the parade which only serves to further fuel their opposition to it" (PC on Tour of the North 1998: np). In the Ormeau Road area, the PC noted a more symbolic form of disruption, where, because of "the alleged aggressive and paramilitaristic nature of some parades, Catholic residents, in particular, had been frightened to leave their homes" (PC on the Lower Ormeau Road 1998: 7). 
Regarding the police security measures which were argued to curtail freedom of movement, the PC did not deliberate on whether such police action was justified; rather, what was deemed important was how parades were perceived by local residents: "Whatever the reason for such action, from what we were told this has become another aspect which has close association with parades passing through the area in the minds of many Catholic residents" (PC on the Lower Ormeau Road 1998: 7). Ultimately, given the governmental understanding of the problem at the time, the PC aimed to know parades in terms of relationships, which meant mapping 'perceptions', 'feelings', and 'tensions' between groups, most evident with the factor 'impact on relationships within the community.'

Mapping 'community relations': feelings, perceptions, tensions

'The impact of the procession on relationships within the community' was the most detailed and thoroughly developed factor in the Guidelines. The Guidelines stressed: “As the past has shown, there is huge potential for unresolved disputes over processions to create major and lasting rifts in relationships between communities... Often these disputes are symptoms of more deeply rooted conflict but they can provoke a violent response which only serves to tear communities further apart" (4.1).

In assessing 'the impact of the procession on relationships within the community', the Commission was to consider a number of factors:

\section{- Location and Route}

Where there was conflict between residents and parade organisers over the route of a proposed parade, the Commission was to take into account:

i) the extent to which contested parts of the route comprise mainly residential or commercial property.

ii) the demographic balance among the residents in the immediate area surrounding any contested parts of the route.

iii) the presence of sites such as monuments or churches of other traditions or other sites associated with past events which give rise to sensitivity within the community. 
iv) the purpose of the parade and whether the route is necessary or proportional to that.

v) the availability of alternative routes which are non-controversial. (PC Guidelines 1998: 4.2)

Regarding demographics, again, this factor meant specifying who lived in a particular area according to religious and political divisions. Such an assessment meant identifying and so constituting a particular location according to certain characteristics of the population. Also, certain material and geographical sites were constituted as 'giving rise to sensitivity within the community'. The use of the term 'sensitive' may be understood as code marking where the Commission was to intervene in how parading takes place. Further, in considering the purpose of the parade in its determinations and the availability of alternative routes, the Commission was positioned as the authority able to judge the significance of parades, with some purposes for parading deemed more acceptable than others.

\section{- Type and frequency of parades}

The Guidelines recognized "as a general principle that residents along the route of a parade have the reasonable expectation not to feel fear or a sense of intimidation because a parade is planned". It is stated that "past events in the area will have a bearing on local sensitivities" (4.3). 'Past events' likely meant any past occurrence of politically-related violence, whether it was related to past parades in the area, or to IRA or loyalist paramilitary activity, either historically or more recently. It was tacitly understood that politically-violent events in a community 'lead to sensitivities' ${ }^{50}$

In attempting to measure fear or sense of intimidation, the Commission will take

\footnotetext{
50 The notion of 'sensitivities' merits further elaboration in that it is related or linked to emotions. Governing parades ties into governing emotional states described as 'sensitive', and characterized as somewhat irrational, requiring governmental care and caution. The strategies of governing deployed towards parades are particular to what are deemed 'sensitive' communities. Or, it is to say the techniques of government re-constitute/assemble communities as 'sensitive' and so in need of a particular governing approach.
} 
into account:

i) the purpose of the parade.

ii) the numbers taking part.

iii) past experience of the manner in which the parade has been conducted.

iv) the regalia associated with the parade.

v) the nature and number of bands that will participate and the type of music they will play

vi) the frequency of such parades along the route. (PC Guidelines 1998: 4.3)

The above factors worked to specify a parade that infringes on the rights of others.

\section{- The Broader Context}

The final factor used to assess 'the impact of a parade on relationships within the community' is the history of 'inter-communal strife'. The Commission must hear through testimony the relationship between "those circumstances and the proposed parade". This consideration explicitly assess the state of community relations in the location the proposed parade is to take place. It also considers how a parade in this area will effect 'the wider Northern Ireland community' (PC Guidelines 1998: 4.4).

In the preliminary views, the Commission devoted most time and space to evidence of how parading impacted, or in practice, harmed, 'community relations' in each locality. The PC worked to construct the historical and existing sectarian divisions in the area (to construct a picture of the 'health' of community relations), and to discover the role of parading - any aspect of it that emerged as relevant - in harming such relations (increasing 'tensions', divisions, and conflict). In documenting 'the impact of parades on relationships within the community', the PC worked to map the local political relations in which parading was seen to take place. Local feelings and 'sensitivities', forms of knowledge ('perceptions'), and relations were made the terrain of government. As with the other factors, assessing parades for their 'impact on community relations' significantly broadened the reach of government. 
Gathering views worked to specify what elements of parading were potentially problematic insofar as causing 'offense', being seen as 'provocative' or 'sensitive', while equally constructing a sense of what forms of parading were seen as more acceptable and legitimate. The factor 'impact on relationships within the community' was a catch-all that allowed the PC to consider almost anything and everything if it deemed there may be an impact on relationships. A number of aspects of parades emerged as problematic and in need of governmental attention: first and foremost the route of parades, followed closely by conduct while on parade. However, beyond the route and manner of marching, other aspects emerged as problematic to 'community relations', such as conduct in organizing a march, the flags or banners carried, the types of songs played, the number of parades during the year, the timing of parades, the number of bands participating, the security measures taken, the use of alcohol, the behaviour of supporters, as well as certain types of marches themselves (band parades or 'non-traditional' parades vs. church parades), among other points. ${ }^{51}$ The evidence discussed significantly overlapped with the other factors, which also commented on behaviours, routes, feelings, and perceptions; however, in this section such aspects were more fully detailed.

The following are examples of the types of statements made in the 1998 preliminary views. The Commission aimed to document the key factors of disputes in each location. In Pomeroy, the Commission noted concerns around the route, the manner of marching, regalia and music:

Parades take the only available route from the bottom of the village to the two Protestant Churches. The direct route to the Presbyterian church is not contested, but the Church of Ireland church is situated in the Diamond, and the march around the Diamond area, which is now wholly nationalist, is the focus of dispute....

\footnotetext{
51 The emergence of these 'problems' happened much earlier than when the PC had to make determinations. These aspects came to light when parading was first subject to review, leading up to and with the North Report.
} 
We were told by some that a church parade each year to each of the churches would be accepted, provided that the parade went straight into the Church of Ireland and did not march around the Diamond; although we also heard the view that a parade around the Diamond, properly conducted would be acceptable to moderate nationalists. ...

On regalia and music, we heard that non-provocative banners and hymn tunes were not objectionable to moderate nationalist opinion as an expression of Protestant culture. Some, however, expressed acceptance of marchers in the two church parades wearing sashes and of bands playing religious music, but not of marchers carrying any flags and banners, which they saw as symbols of supremacy. (PC on Pomeroy 1998: 6)

In Bellaghy, the Commission noted sentiments towards particular types of parades and types of music, stating that the local band was "clearly regarded as traditional and generally acceptable insofar as it played hymn tunes for Church parades and some traditional Orange music on marches such as the Twelfth". It was noted that "flags and emblems had caused some offense in the past but were not a main source of contention..." (PC on Bellaghy 1998: 7). In the Ormeau Road, the Commission also noted concern around 'parade types', stating that there was a "growing perception" of "an increasing number of nontraditional parades, particularly through side streets ... Given the mixed population in that area, it was put to us that this proliferation was a disturbing feature". Further noted were concerns around types of bands, their behaviour, and regalia carried: "There were also concerns about the nature of bands in previous years and the behaviour of participants and followers. And there were general concerns about the nature of regalia in some parades in the past which had contributed to the perception by the Community in the Lower Ormeau of parades as sectarian and triumphalist" (PC on the Lower Ormeau Road 1998: 8). A final example, regarding the Tour of the North, the Commission noted issues around a lack of engagement, and the symbolic meaning of the parade to the Protestant community:

There was resentment at the fact that the Orange Order had not made any attempts to engage with the community to address their concerns about the parade. ... 
The parade clearly has a symbolic significance for the Protestant community in the area....

We are aware that there is a sense of contested territory created by the significant population shift over the past years and that a concession by the Orange Order to parade in the contested area would be seen as the loyalist community ceding further territory to nationalists. (PC on Tour of the North 1998: np)

The concerns raised under the factor 'impact on relationships within the community' worked to constitute local parading politics and to bring the Commission's attention to potentially problematic aspects of parades. Such aspects or facets formed parading as a tangible, actionable object of government and signaled to the Commission where it ought to intervene, whether through more subtle governing tactics, such as the construction of 'right' knowledge to change perceptions, or through more explicit tactics, such as through making determinations.

In 'gathering evidence' on parading according to the administrative frame, the Guideline factors, the field of government came to include the wider social and political 'environment' or 'milieu' in which parading occurred. The Commission worked to constitute the state of 'community relations' based on which it could assess future parades. In doing so, the governing regime captured events, actions, relations, and ways of thinking and living in areas where parades were deemed contentious. In the conclusion of the preliminary views, the PC made an overall assessment of the state of parading in the area, indicating how it would rule on future disputes. In Bellaghy, the PC concluded: "We do not believe that at present the relationships between the communities are yet conducive to [parades taking place without conflict]" (PC on Bellaghy 1998: 9). On the Tour of the North, the PC concluded route restrictions were necessary: "Given the current political atmosphere surrounding this year's proposed event and its timing shortly before the Assembly elections we think that the 
situation is likely to be even more explosive than in 1996" (PC on the Tour of the North 1998: np).

'Parading' was rendered knowable through the already defined territorial spaces where it took place, both material and imagined. Geographical locations, as well as the imagined spatial divisions between the two communities deemed to reside within, acted as organizational frames through which parading was thinkable. Parade disputes, in some cases more clearly than in others, were understood as a struggle for territory; a response to demographic changes which left the Protestant community feeling vulnerable. On occasion, as in the case of the Tour of the North, the PC worked to shift such a perception away from being about territory towards being a matter of sharing space. ${ }^{52}$ On concluding it ought to restrict the route of the parade, the PC stated: "This is not a question of conceding territory, or, indeed of seeking permission of others to exercise fundamental rights. It is a question of how two beleaguered communities with a relationship that is bedeviled by the scars of the past, can best share the space that is available to them" (PC on the Tour of the North 1998: np).

That parade disputes were a problem of relationships was underscored by the Commission after its evidence-gathering exercise. Based on the preliminary views, a number of 'common features' emerged which the PC saw as "the key underlying problems in disputes over parades" (PC AR 1999: 15). ${ }^{53}$ In the First Annual Report, the Commission reaffirmed that the "issue of relationships lies at the heart of the parades conflict". It pointed to a need for 'mutual respect' between "communities with different cultural and religious traditions" and stated that mutual respect was an "important standard of a stable pluralist

\footnotetext{
${ }^{52}$ In later years, the PC framed restrictions as a matter of balancing human rights, working further to break the link between parading and territory.

53 'AR' refers to Annual Report.
} 
society" (PC AR 1999: 16). The "issue of perception" was also identified by the PC as "one of the most significant underlying features of disputes over parades". The issue was said to be "compounded by the absence of dialogue as a means of exploring and overcoming false perceptions between the disputants" (PC AR 1999: 18).

The evidence-gathering exercise also allowed the Commission to detail problem behaviour and relations, such as when conduct signaled 'mutual respect' and when it did not. The PC pointed to the failure of the Loyal Orders to recognize concerns widely held in nationalist communities, which "was manifested in their determination to celebrate their exclusive cultural traditions in nationalist areas". At the same time, it pointed out that the way protests were often conducted, with symbols the unionist community found offensive, “did not signal a commitment to mutual respect” (PC AR 1999: 16). Through knowledge practices, such as gathering views and opinions, the object of government was increasingly specified.

In later determinations, it is difficult to trace the Commission's thinking behind decisions; determinations become increasingly standardized and the once visible process becomes hidden in favour of a human rights discourse, a subject addressed in the next chapter.

\section{The administrative process}

In addition to the preliminary views gathered in 1998, the Commission relied on a standardized administrative process to gather information to make determinations. Information primarily came from Authorised Officers, the police, and volunteer monitors, as well as parades organizations and protest groups. What follows reviews the administrative process through which contentious parades were invested in a governable form. The

discussion draws from my time spent at the Parades Commission office (primarily in July 
2009), as well as from informal discussions with the Commission's secretariat and an Authorised Officer (July 2009, July 2011).

The Parades Commission held what were called 'determination meetings' on a weekly basis at the Parades Commission office in central Belfast. Meetings took place in a conference room where the Commissioners and others involved gathered around a large oval table. In a single day, the Commission considered a number of parades deemed contentious which were scheduled to take place in the upcoming ten days or so, and it issued a determination for each parade. Some parades might have had conditions imposed, and some might not. Decisions were made based on the information assembled from a variety of sources. In each meeting, Commissioners were given 'information packs' produced by the secretariat with the relevant information on the parades to be considered that day. Included in the Commissioner packs were reports by Authorised Officers, a report from the police, and past monitor reports. As noted in the Procedural Rules, the Commission also gathered evidence at the time of the meeting. It encouraged parade and protest organizers to come in and 'represent' their event.

Authorised Officers (AOs)

For each parade deemed contentious, the Commission sent a form to AOs called 'PC1'. ${ }^{54}$ The PC1 acted as a 'prompt' for AO's to fill in a report on the parade called the 'PC2'. Also sent to AOs was the 11/1 (the parade notification form) with the details of the parade for their consideration. The PC1 identified parades by reference number, date, name of organizing body, and location. The PC1 indicated the date by which the PC2 report was needed and the date the parade was to be considered by the Parades Commission. The

\footnotetext{
${ }^{54}$ The role of Authorised Officers, the number of them, and how they work in relation to the whole of Northern Ireland has changed over the years. In 2011, the role was eliminated (I believe due to budget cuts).
} 
timelines were quite short. For instance, AOs might have ten days to send to the Commission the PC2. Once the Commission received the form, the determination meeting might be held about seven days later.

The PC2 contained six questions to be answered by AOs about a particular parade. The report opened with a section where AOs were to write any 'background' information on the parade. Then the questions were listed as follows: ${ }^{55}$

1. Have the following interests been contacted in respect of this parade? Organizer, police, resident groups, local clergy, politicians, community representatives, other to be specified.

2. What is the likely effect on community relations of this parade proceeding as notified?

3. What is the likely effect on community relations of a restriction on this notified parade?

4. What is your assessment of the impact of this parade on community life (e.g. freedom of movement, business interest, privacy etc)?

5. Are there any concerns that the Code of Conduct will be breached (e.g. history of parade, participants, protestors, marshals)?

6. How interested is the parade organiser to address issues of concern about the parade (e.g. is he willing to discuss issues of concern with AO's, police, residents etc.)?

At the end of the report there is a space titled 'options' where the AOs were to 'flag' options they thought the Parades Commission should consider in terms of dealing with the parade. The PC2 report was sent to the secretariat of the Parades Commission.

In filling out the PC2 report, AOs drew on what were called 'Location Briefs'. Locations Briefs were written by AOs once a year for every ‘contentious location' where parades took place. The brief was an overview of key issues in that area. The key

\footnotetext{
${ }^{55}$ I was not allowed to see a completed PC2 report due to confidentiality. I was given a copy of the template.
} 
'stakeholders' were identified, any progress that was made over the winter was documented, as were the main issues that needed to be tackled. This was normally done in the spring and sent to the Parades Commission. Some parade locations remained static, while in others there was significant change. ${ }^{56}$

The police report: The $11 / 9$

The police were also to send a report to the PC for each parade deemed contentious. The form was known as 11/9 and was titled the "Public Procession Report". The 11/9 consisted of seven main sections. The first several sections identified the parade: Name, location and date were asked for; the 'affected districts' that the parade entered were to be listed; the route of the parade detailed and a map attached where possible. Recent parading history was then asked for:

A factual synopsis of sensitive parades at this venue for last $2 / 3$ years should be given. Where there has been significant disorder or protests in a particular area this should be quoted. Human rights implications of previous police strategies should be included. Great depth of detail is not required. Reference should be made to other evidence that is available -for example video footage.

The fifth section concerned compliance with and previous breaches of the Parades Commission Code of Conduct. Section six asked police to include details relating to public disorder or damage to property which had occurred previously related to the parade. The form notes this factor must be taken into consideration when the Parades Commission makes its determination. The police were to include a separate section both on the parade and protest, stating for each "the extent to which participants [or protestors] gave rise to the disorder or damage to property and the likelihood that the behaviour of participants [or protesters] directly caused or led to the disorder. No's of participants [protestors] and details of arrests/prosecutions should be quoted".

${ }^{56}$ Based on a conversation with an AO. Also see Jarman, Rallings and Bell (2009). 
Section seven was a "Community Impact Assessment". The form states that "Impacts within the community should cover the degree to which a parade or parades have already caused or might cause division between communities. Where pertinent historic reasons exist why a parade is sensitive and if relevant they should be included. Relevant tension indicators should be quoted". ${ }^{77}$ Police were also asked to indicate the extent to which the parade would disrupt the life of the community, which it stated would include "adverse effects the procession would cause to normal everyday life".

The rest of the form asked police to "make a judged assessment of how police strategies might affect the rights of individuals who may be affected". The strategies used by police to prohibit a parade or block a protest were understood potentially to infringe on human rights. Several rights in the European Convention of Human Rights were listed for consideration. ${ }^{58}$ This report was included in the information packs provided to the Commissioners.

The above forms were information-gathering tools which were an important part of rendering parades knowable and calculable. The forms worked to invest (give shape to) the domain of parading by reporting on 'community relations', on the impact of parades on 'community life', and on the conduct of parade participants, and protestors, as well as the willingness of parade organizers to 'engage' in discussions.

${ }^{57} \mathrm{I}$ infer based on attendance at a determination meeting that these 'tension indicators' meant, in part, reported incidents in the area which were suggestive of inter-community conflict, such as paint bombing churches, memorials or other such 'symbolic assaults'.

${ }^{58}$ The rights listed were: the individual's right to life, liberty, respect for private and family life, freedom of thought, conscience and religion, freedom of expression, and prohibition of discrimination. 


\section{Determination meetings}

The general structure of determination meetings was as follows. ${ }^{59}$ Meetings started at $10 \mathrm{am}$. The Chair opened the meeting by discussing any 'issues' that came up during the week. This took about 10-15 minutes. Then the media liaison for the PC gave an overview of the key stories in the media that week and alerted the PC to 'anything they needed to be made aware of. The PC was given the opportunity to say something publicly if it desired. Then the parades were considered case by case.

The Commission followed a series of steps for each parade in order to arrive at a determination. If a parade had representation, then these individual(s) would be asked to enter the room and speak first. The presentations, which were usually given a 20 minute time slot, were not to be about justifying a parade, or making arguments, but more about factual clarification regarding the organization of the parade, including security measures in place. Once the parade representation exited the room, the representative of the protest group would enter and share its concerns. Interestingly, the Commission offices were designed so that each group could enter and exit the office in a circular fashion so as not to run into one another at the meeting.

Next, the police would enter the room to discuss the particular case. After the police, the AOs would be asked to give their point of view based on the presentations given, as well as their thoughts on options to deal with the parade. AOs were then asked to step out of the room while the Commissioners made a decision. Once the decision was made, a case worker (one responsible for the location in which the parade was to take place) put the determination document together. The document was signed and immediately sent to the

\footnotetext{
${ }^{59} \mathrm{My}$ account of the meeting structure is based on a conversation with an AO in July 2009. The structure must be read as particular to the Commission members in 2009 and is intended to give the reader a general sense of how meetings unfolded.
} 
parade organizer by courier. The whole cycle per parade could take 1.5 hours or less. When there was no representation, the Commission made a decision based solely on the information available and the decision could be made fairly quickly.

\section{Monitoring and reporting on contentious parades}

Part of the governing process required the Parades Commission to keep itself informed of how parades took place. There were three governing bodies that attended, observed, and otherwise had a presence at contentious parades: 1) police, 2) Authorised Officers, and 3) monitors. Each of these groups, in one way or another, reported to the PC on how parades took place. These reports fed back into the governing process, shaping how parades were to be administered going forward. The feedback of AOs was reflected in the PC2 report and in conversations at determination meetings. The police and monitors had a more formal reporting procedure to follow, in that there were forms to complete.

For each contentious parade, a police officer was to complete form 11/8, titled 'Post Public Procession Return'. This information was to be faxed to the Police Service of Northern Ireland Parades Commission Liaison Officer. The form was one page long and opened with the basic classifying information on a parade, including 'date, time, venue', followed by 'organization', followed by whether a determination was issued by the Commission, and whether there was a protest meeting involved. The thrust of the form required detailing a "brief resume" of the procession "including numbers of bands and marchers, any disorder/breaches of Codes of Conduct by procession and/or protesters". It asked to "include any significant damage to property etc.". Finally, the officer was to note any details of arrests and reasons for arrests.

After a parade, monitors were to fill in what was called an 'Observation Report' which was sent to the Parades Commission. The monitor report form was an important 
technology of government. Events were translated through the technology of the report into a form that was 'readable' by the governing body. The information contained in the report had an impact on future PC decisions regarding that parade. The PC was to take into account past conduct in its future decisions, meaning, poor conduct reported would have consequences on future abilities to parade as desired.

Monitors were considered 'neutral' observers and worked through appearing objective in their gaze. However, through their training and through the nature of the form to be completed, monitors themselves were governed to look upon the parade through a particular lens - the lens of government. The report form defined who was to be observed and what manner of conduct was considered 'normal' and desirable.

The first section of the report form asks for feedback on 'Those on Parade' (as the section is titled). First, monitors were to estimate the number of individuals on parade and the number of bands. They were to note what time the parade started and ended. Second, they were to provide comments on the behaviour of those on parade. Monitors were to comment on "compliance or otherwise" with the Parades Commission conditions, as well as "compliance or otherwise" with the Code of Conduct. Regarding commenting on compliance with the Code of Conduct, the form gives examples (in brackets) of what monitors should note: "Behaviour / Dress / Positioning of Parade / Alcohol / Bands \& Music / Flags etc / Stewards / Co-operation with police / Dispersal”. These categories constitute the elements of a parade deemed problematic and in need of governmental attention.

The next two sections ask for comments on both the "Spectators and Supporters of the Parade" and "Those Protesting to/ Opposed to the Parade". This required monitors to be able to distinguish between supporters and protestors at events. For each group, monitors 
were to estimate the number of people participating. Then they were to comment on "Behaviour/Location / Alcohol / Flags etc /Chants/ Co-operation with Stewards and /or Police". In the section dealing with protestors, the word "banners" is written in place of "flags". Again, these categories constitute the potential 'problem' elements of groups involved in either supporting or protesting a parade.

The next section centers on the "The Police". Monitors were to estimate the number of police present at the event. They were to comment on "location / visibility / uniform / vehicles / dogs / weapons carried or used / response to breaches of the Commission's determination and/or Code of Conduct / duration of road closures / withdrawal". Note this section does not ask for comments on police 'behaviour', rather it is focuses on the police strategies and measures taken to deal with the parade. These categories specify the elements of police presence at events deemed potentially problematic.

The next section asks monitors to reproduce the "Sequence of Events" and to fill in three columns tracing how the event took place. Monitors are to note the 'time', the 'event', and then to write 'comments' in the final column. This worked to re-create a documented/written representation of what happened 'on the ground'.

The final section of the report is a fairly new addition to the form template. It consists of "The 12-point Parade Scale" which monitors were to use in order to assess/locate/judge the parade in terms of contentiousness (See Figure 3). The scale worked to define what counted as a highly contentious parade, a less contentious parade, and a noncontentious parade.

As noted with the 'scale of engagement' in the previous chapter, such scaling invests the grounds of parading by categorizing social conduct. A range of conduct was broken down and assigned as either 'non-contentious', 'contentious but orderly', 'poor behaviour', 
Figure 3 - 'The 12-point Parade Scale'

12 Serious injury associated with the parade

11 Physical contact between paraders and those opposed to the parade or the police

Violent

10 Missiles thrown by parade participants, perhaps in response to an attack from protesters

$9 \quad$ Parade displaying hostility to those opposed to the parade

8 Parade organiser breaching a determination

7 Parade organiser refusing to cooperate with police or AOs, parade Poor behaviour displaying poor behaviour

6 Parade largely orderly but poor behaviour by supporters or protestors

5 Parade displaying aspects of poor behaviour and some breaches of the Code of Conduct in an area where there is opposition to parades.

4 A largely well-managed parade in an area that experiences opposition to parades. Some poor behaviour perhaps by supporters.

Contentious, but orderly

3 A well managed parade with no breaches of the Code of Conduct, but experiencing opposition

2 No opposition to parade, but parade displaying aspects of poor behaviour. No breaches of the Code of Conduct

Non-

1 No opposition to parade, parade orderly and dignified contentious

Source: Parades Commission. Monitor's 'Observation Report'. On file with author. 
and 'violent'. Once assigned to the category, the object of government, 'a parade', becomes actionable within the governing regime. Again, scaling enables normalization by categorizing particular behaviour according to certain positive and negative attributes. A desirable parade was defined as having no opposition and where parade behaviour was 'orderly' and 'dignified'. It must be noted, the scale is somewhat vague as it does not specify certain elements, such what constitutes 'poor behaviour'; rather, it relies on the tacit knowledge of monitors.

\section{Conclusion}

This chapter elucidated the knowledge practices used by the Parades Commission to make determinations; practices which, I argue, worked to constitute parading as an object of government. I examined the Commission's 'evidence-gathering' procedures, including the Procedural Rules and Guidelines documents, both of which informed the type of information collected to take a 'preliminary view' on parades/locations deemed contentious in 1998. What emerged from the analysis was the central importance of a particular constitution of space in Northern Ireland. Governing parades relied on already-defined territorial boundaries divided according to religious/political groupings. That is to say, parades could not be thought or governed without the territorialization of such identity groups. The attempt to know and calculate parades proceeded by assessments of locations deemed problematic, which were defined as such mainly by the existence of protest. Protest was a clear and visible marker of struggle. Further, the field of intervention came to include a wide range of conduct and relations in spaces across Northern Ireland. The reach of government was significantly expanded from when parades were policed as problems of public order. 
The final section of the chapter highlighted the administrative procedures that went into making determinations. The information-gathering forms, meetings, and follow-up forms were central to constituting parades as actionable objects. It was only though such means, and the forms of knowledge assembled, that the Commission could make decisions. The following chapter discusses the challenges and transformations in making determinations, primarily brought on by the incorporation of the European Convention on Human Rights in October 2000. 


\section{Chapter Six \\ Challenges and Transformations in Making Determinations and the Rise of a Human Rights Discourse}

\section{Introduction}

In previous chapters of this dissertation, I have discussed various aspects related to determinations. In chapter four, I discussed the approach taken by the Parades Commission in making its first set of determinations. In 1998, determination documents, as well as the Commission's First Annual Report (1999), made clear that parades were restricted expressly on the basis of a lack of 'engagement'.

By its third year of operation, the Commission's approach to making and articulating determinations changed: parading was re-invested in the form of human rights. With the incorporation of the European Convention on Human Rights (ECHR) into UK law on 2 October 2000, the Commission adopted a human rights framework to situate and frame its decision-making. Parade disputes were to be understood as a conflict of rights, those involved in disputes were conceptualized as rights-bearing subjects, and the Commission itself was constituted as a rights-weighing machine. While early decisions were articulated as what the Commission simply 'believed' or 'felt', and were therefore clearly subjective, later decisions were made to appear more objective by being rooted in human rights legislation. 'Engagement' was still assessed; however, decisions were no longer articulated based on this factor alone. Decisions were increasingly removed from explicitly disciplining individual conduct, and instead said to be made with the aim of preventing disorder and for the protection of the rights and freedoms of others. In adopting a human rights framework, the Parades Commission and its decisions now appeared rooted in something bigger than the Commission itself. 
Along with the adoption of a human rights discourse, other changes in the presentation of determinations are evident. Early determination documents were inconsistent in their format, their explanation (reasoning), and decision-making, while later documents became more standardized, following the same format in each case. Overall, the process of making determinations became increasingly governmentalized. Rather than rule through the imposition of a standard and then punish parade organizers when that standard was not met, the later Commission constituted subjects expected to govern themselves in light of their rights and responsibilities. While the Commission consistently worked to foster self-governing subjects, it was carried out through evolving governing tactics and a reinvestment in forms.

This chapter discusses the transformation of the Commission's early determinations. The rise of a human rights discourse and the increasing governmentalization of the Commission did not happen in a vacuum. Much of what took place occurred in relation to challenges to the Commission's authority, mainly from the Orange Order. The adoption of a human rights framework partly arose because of a need for the governing body to gain legitimacy, as well as to protect itself from legal challenges to its decisions.

\section{Early determinations}

In that this chapter aims to demonstrate how the Commission's determinations (as a governing tactic) changed over time, it is useful to briefly return to early determination documents. When the Commission first began making determinations, there was no precedent to follow, nor a clear set of standards to use in deciding the conditions under which parades ought to take place. While the Commission had statutory guidelines to apply, and while the body had outlined key factors it was to consider in relation to each guideline, the weight or value the Commission was to attach to each factor, in other words, the manner of 
assessment to be used, remained vague. For instance, once the Commission gathered 'evidence', such as the demography of the area in which a parade was to pass, and the views, feelings, and perceptions of both local residents and parade organizers, how did the Commission actually assess or calculate the impact of a proposed parade? How did the body decide what constituted 'appropriate' parade conditions in each case? Legal scholar Imelda McAuley (1998), makes a similar point (albeit from a legal perspective) and notes that the early Commission was not practically in any better position to assess disputes than was the RUC previously. McAuley states that while the guideline factors outline the main points of contention, applying them would be difficult since they "do not tackle head-on the complexities which lie at the heart of the matter". For instance, with the factor 'impact on relationships within the community', McAuley states: "Although this principle was identified by the North Review as an essential criterion of assessment, the fundamental difficulty of how much weight to attach to the impact of a parade on those who do not agree with it remains" (McAuley 1998: 53). Further:

The essence of the conflict over parades in Northern Ireland... is whether a route is "necessary" when a parade follows a traditional route and, indeed, how much weight should be attached to the fact that a parade is a traditional parade when it gives offence to those who now live in an area through which the parade passes. Thus, although the factors which give rise to conflict have been expressly articulated in the proposed statutory criteria and the guidelines, the fundamental problem of when the law should intervene to re-route or stop a parade from proceeding on the basis that it gives offence remains. (McAuley 1998: 53-54)

However, the fact is, the early Commission did weigh the various factors against each other in order to make determinations in 1998. From a governmentality perspective, a form of calculation or reasoning was indeed applied, even if not readily apparent. As previously discussed, the Commission most obviously applied a disciplinary logic based on the factor of 'engagement'. 'Engagement' was the standard for good/responsible behaviour and restrictions were made expressly on this basis. Other factors were more tacitly assessed, 
weighed and decided upon. For instance, the Commission reasoned its decisions to impose or not to impose conditions on a parade based on some assessment of that which would harm community relationships. In its 1998 determinations, it was common for the Commission to state: "we do not believe the relationships between the communities are yet conducive to parades taking place along the entire traditional route in an atmosphere free of conflict" (PC on Bellaghy 1998: 10). Some form of calculation was used to reach this decision.

Determinations were made based on a tacit underlying evaluation of the significance of the symbolic, such as the meaning of a parade or the meaning of the route, as is evident in the following examples. In the case of a proposed parade in Crumlin, the Commission assessed that restrictions on a traditional parade that is very infrequently held would do more harm to community relations than allowing the parade to take place unrestricted:

In relation to impact on relationships within the community, we acknowledge that a significant number of residents object to this event being held in Crumlin. However, we consider that to interfere with a traditional parade which occurs only every 14 years in Crumlin could have the most destructive impact on relationships within the community. It would drive further wedges between both sections of the Community.... (PC on Crumlin 1998)

In the decision on a parade in Pomeroy (1998), the PC stated: "We feel that there is no practical purpose for this parade to proceed beyond the Presbyterian Church, around the Diamond and back to the Presbyterian Church: if it were to do so it would be likely to have an adverse impact on relationships within the community, in light of what we were told and previous reactions to the parade" (9). In stating that it sees no 'practical purpose' in the proposed parade route, the Commission made a judgment on the symbolic meaning of the route - in effect, deciding that a parade around the Diamond was not symbolically significant - or, in other words, it was not an appropriate part of the parade's symbolic expression. In the Crumlin case, the Commission decided that a parade deemed traditional, 
held only every 14 years, was legitimately symbolically significant and therefore important to allow.

In another example of governing the symbolic, in relation to imposed route restrictions on a 1998 Bellaghy parade, the PC stated that despite the restrictions, "we do believe that a parade from the Orange Hall to the Church of Ireland and back still represents a significant parade for the lodges concerned" (1998: 10). The Commission clearly governed parades in 1998 based on underlying ideas of what counted as symbolically significant - an understanding with which marching organizations would no doubt disagree.

The Commission's reasoning might best be described as liberal 'common sense'. The body's interpretation of the 'evidence' it collected relied on normalized assumptions about group conduct, local political relations, normative ideas about order/disorder and disruption, as well as liberal democratic notions of what constitutes a civil society. While 'disruption' was understood to be inevitable, 'disorder' was not. For instance, again in reference to the proposed parade in Crumlin we note a common-sense logic at work:

We have considered all the factors. There is scope for disorder if anyone in the parade acts in a provocative way towards those who oppose it, or if protest action against the parade proceeds in an illegal manner. There is, however, no reason why either should be the case. There will also be disruption to the life of the community which is an inevitable aspect of a parade on this scale taking place in a town the size of Crumlin. (PC on Crumin 1998)

The Commission was (and still is) adamant that disorder is not an inevitable feature of parades, effectively making the point that disorderly conduct is a choice of those who participate in and attend parades. With this framing, the Commission constitutes selfgoverning subjects with the capacity to parade in an orderly manner. Turning disorder into an individual and collective choice works to govern the conduct of those involved in parades - a point which illustrates how different modes of power (sovereignty, discipline, government) can work together in the same tactic. Determinations are hybrid governing 
tactics in that they are at once repressive (in imposing restrictions) and governing (through the discourse of the determination document itself).

In the early years of making determinations then (the first and second years at least), parade decisions were not framed as a question of balancing human rights, but rather as a question of 'community relationships', parading 'atmosphere', and 'responsible' conduct, largely on the part of parade organizers. It is noteworthy that the common language of early PC decisions was framed in terms of 'we believe', 'we feel', 'we think', 'we are of the view' etc. Underlying the claims to objectivity and transparency, and the appearance of clear guidelines according to which each case would be assessed, the early Commission relied on everyday local knowledge to make its decisions.

Given that the body was the first of its kind and therefore without precedent (no other known examples of a 'Parades Commission' existed), and given the lack of a transparent, readily-applicable manner of assessment, early determinations were inconsistent in both the decisions made, and in the format of the documents themselves. Determinations were short, usually one or two pages long, and presented in various ways. For instance, similar content was put under different headings, and some determinations had more explanation than others. There was a lack of clarity in how to make, articulate and explain decisions, as well as how to present them in written form.

As will be demonstrated in the following sections, with criticisms of the Commission's decision-making and the development of a human rights discourse in Northern Ireland, there was a shift in how determinations were rationalized and framed the once clearly subjective assessment of parades and local symbolic politics, was largely removed from view and in its place was the appearance of a legal/rationalistic application of human rights principles. There is no evidence that the actual form of calculation behind the 
Commission's decisions changed; rather, it was the articulation of determinations that underwent a significant transformation.

\section{Governing the governors}

The following section discusses the context in which governing advances and develops. In the case of the early Commission, such transformation occurred both in the face of criticism and resistance, and through self-reflection and seeking the guidance of experts in human rights law. Also noteworthy is an external review of the Commission's procedures launched in October 1999 by the Northern Ireland Office (NIO), whose findings were announced in 2000. The review was launched in the hopes of bringing about a greater consensus on the solution to disputed parades (as well as to improve the procedures for mediation).

\section{The Orange Order and resistance to the early Parades Commission}

Since its inception, the Parades Commission has been controversial. Jarman writes that upon the creation of the body "the nationalist community was broadly supportive, whereas unionists were generally suspicious and hostile towards it" (2003: 96). He notes that unionists "saw the Commission as being designed to put a legal gloss on the desire to stop parades" (Jarman 2003: 96). The Grand Orange Lodge of Ireland (hereinafter, the Grand Lodge), the organisation which leads the Orange Order, was especially resistant to the Commission and the overall policy towards parades outlined in the North Report. It did not agree with the new governmental framing of the 'parades problem' as one of 'community relationships'; rather, it argued that the problem lay with those who caused disorder. In its view, disorder did not stem from those intending 'to exercise their inalienable rights to free assembly with a peaceful parade'; disorder came from those opposed to parades. The solution, therefore, ought not to focus on restricting parades, but on managing the disorderly 
conduct of those who wish to deny others their basic human rights. The Commission was portrayed as a repressive body aiding the denial of rights.

The Orange Order refused to acknowledge the existence of the Commission through a formal policy of 'non-engagement'. This meant that some parade organisers would not engage with Authorised Officers or give evidence (representation) to commissioners. The Order also balked at the call to engage in dialogue with residents' groups. Residents' groups were seen as a front for the Sinn Féin/IRA's political agenda of preventing parades. Further, the Order interpreted the expectation of dialogue as tantamount to 'requesting permission' to parade, which it argued violated its rights of free of assembly. In the First Annual Report, the Commission stated that its efforts have been "hampered" by the "policy of nonengagement" by some of the Loyal Orders and that such a policy will continue to "blight the prospects of achieving a peaceful resolution to parade disputes across NI" (PC AR 1999: 13). Jarman notes that the non-engagement of the Orange Order, and subsequent restrictions on parades due to lack of mediation and local accommodation, fueled the perception that the Commission was an 'anti-parading body' (2003: 96).

The Grand Lodge published The Case Against the Parades Commission (circa late 1999), which presented a lengthy and detailed critique of the Commission - its founding legislation, the determinations made in 1998 and 1999, the draft code of conduct, and the Commission's guidelines. In general, the Grand Lodge challenged the legitimacy of the Commission. The Public Processions (Northern Ireland) Act was argued fundamentally to undermine the basic human rights of freedom of assembly and freedom of movement. It was argued that the Commission was "an unelected quango allegedly accountable to no one for the decisions it makes". As noted in chapter two on the response to the North Report, the Commission was not seen as independent from the government, but as a body that was likely to do the 
government's political bidding. A further point took issue with the commissioners, arguing that "the Commission is not representative of the Community and it has amongst its members some who have expressed very strong views on parades" (Grand Lodge circa 1999: np).

Specifically in relation to the making of determinations, the Grand Lodge analyzed the decisions made in 1998 and 1999 and argued the following points:

In their determination to date the Parades Commission have:

i) Issued contradictory statements.

ii) Been inaccurate.

iii) Shown little evidence of research.

iv) Taken decisions because of perceived threats from others.

v) Been inconsistent in their determinations.

vi) Shown an obvious lack of accountability. (Grand Lodge circa 1999: np)

The document goes into detail giving examples of each of the above infractions. The takeaway point for our purposes is that through its criticism, the legitimacy, authority, and objectivity of the Commission were put into question by the Grand Lodge. The body's very competence - to rule fairly and consistently - was challenged, as was its ability to understand the context in which parades took place. The Grande Lodge clearly saw itself as the primary expert on all aspects of parades, and it made somewhat of a mockery of the Commission's attempt to know and govern its object. In the section analyzing the Commission's draft Code of Conduct, the Grande Lodge criticizes:

If the route passes through a residential area Parade Organisers again have to let local people know through leaflet drops, newspaper notices etc. Apparently this will allow the local people to amend their routine. Where on earth have the Parades Commission been? The 'residents' on Ormeau Road, Garvaghy Road, etc. have had ample notice of Parades and have actually used the situation to pretend that they were prevented from going about their normal business, even though these Parades were at a time when this is patently untrue. ...

The reasonable steps quoted by the Commission as likely to meet residents concerns are amusing. If they seriously think that furling our banners or playing some 
insignificant tune will please those that categorically state 'No Orange Feet' then again we have to question whether the Commissioners inhabit the real world. ...

The Commission states that it will be necessary to ensure that stewards are well informed of what action should be taken in an emergency situation where, for example, an ambulance, police vehicle or fire engine requires urgent passage along the route.

This is totally patronising. Anyone organising a Parade should have sufficient sense to allow emergency vehicles to proceed. (Grand Lodge circa 1999: np)

From the Commission's perspective, the Orange Order not only hampered the potential for finding local agreements to parade disputes, but it also raised the concern of legal action. The Orange Order's challenge incited a need for the Commission to understand the legalities of its decisions, and to govern itself such that its procedures would hold up to judicial scrutiny if challenged in a court of law. That the Order induced transformations in practices of government epitomizes how power is exercised, not top-down, but in a dynamic relationship with the political field.

\section{Governing the Commission through buman rights}

The Parades Commission was developed at a time when a human rights discourse was increasingly taking centre stage in Northern Ireland politics. Applying a human rights framework to advance the peace process was on the governmental agenda. The 1998 Belfast Agreement centered 'rights' as the way forward for Northern Ireland. The Agreement also laid the basis for the establishment of a Northern Ireland Human Rights Commission (NIHRC), the first of its kind in the UK, and it laid the foundation for the 1998 Human Rights Act. The thrust of the Human Rights Act was to incorporate the European Convention on Human Rights (ECHR) into UK law. While the Act was introduced in 1998, it was incorporated on 2 October 2000. Its incorporation would have several implications. Hamilton et al. (2001) explain: It would enable "for the first time, victims of human rights 
abuses to obtain remedies in local (domestic) courts rather than having to go to the European Court in Strasbourg". Domestic courts would be "required to interpret legislation so as to uphold the Convention rights". Further, the incorporation of the Act would require that all public bodies, including the Parades Commission, be obliged to act in ways that comply with the Convention. "Thus, not only can individuals now rely on the ECHR as a defence in criminal or civil cases, but they may also rely on the Convention when applying for judicial review" (Hamilton et al. 2001: 5). In 1998 then, the Commission knew that the Human Rights Act was going to be implemented and that this would have implications for its decision-making procedures and for potential judicial reviews.

Brice Dickson, the NIHRC's first Chairman, wrote that one of the first questions put to the Human Rights Commission was the relevance of the incorporation of the ECHR for the management of parades and related protests. Based on a meeting between representatives of the Parades Commission and the Human Rights Commission, Dickson stated, "it was clear that the former believed that the latter could give guidance on the issue which would help to ensure a resolution of the marching disputes in Northern Ireland" (2010: 333-334). Dickson noted that this was wishful thinking as "the jurisprudence on Article 11 [the right to freedom of peaceful assembly] was not, and is still not, sufficiently nuanced to allow such guidance to be formulated" (2010: 334). The NIHRC "commissioned a study on the matter from academic experts but this too, while thorough and clear, could not conjure out of the air guidance that simply did not exist in any of the decisions already taken in Strasbourg" (Dickson 2010: 334). ${ }^{60}$ The report, titled Parades, Protests and Policing: A Human Rights Framework, published in March 2001, was authored by legal scholar Michael

${ }^{60}$ The forward to the report states the reason it was commissioned by the NIHRC was "because it wished to make a contribution to the information available to the general public on the relevant legal principles affecting the rights of individuals in relation to parades in Northern Ireland" (Hamilton et al. 2001: i). 
Hamilton, and anthropologists Neil Jarman and Dominic Bryan. The report's summary

states:

This report explores the relevance of international human rights standards, particularly European standards, to parades and protests and the policing of those events in Northern Ireland. If nothing else it reveals the complexity of the issue. There are few simple answers and on occasion case law generated by the European Convention on Human Rights (ECHR) appears contradictory. Human rights legislation will not provide easy solutions to political and community relations problems. However, human rights legislation should make a contribution to providing structures within which disputes can be justly resolved. (Hamilton et al. 2001:v)

There was, therefore, the hope that a human rights framework could help guide the Commission in governing parades. While the 2001 report brought into the public domain the human rights issues involved in the management of parades, in November 1998, Michael Hamilton gave a presentation on human rights to the Parades Commission, only months after the Commission's first summer making determinations. The presentation was based on a paper titled Parades Commission - Politically Correct? (1998). ${ }^{61}$ Hamilton stated that the paper was "directed towards the promotion of three guiding principles - the 3 C's - Consistency, Clarity and Compliance with the European Convention on Human Rights" (ECHR) (1998: 1; emphasis in original). Hamilton referred to Article 11(2) of the European Convention which states that "any restrictions imposed upon the right to freedom of peaceful assembly must be 'necessary in a democratic society"', where he says 'necessity' has been interpreted as a 'pressing social need'. The restrictions "must be 'proportionate to the legitimate aim being pursued' by the authority empowered to impose such restrictions - here, obviously, the Parades Commission" (1998: 1; emphasis in original). He also drew the Commission's attention to a particular case which was exceptional in using a different test of proportionality, one which the Loyal Orders could potentially use to

\footnotetext{
${ }^{61}$ Unpublished document.
} 
challenge the Commission's decisions (2). In the case of Ezelin v France (1991), the European Court decided that restrictions to the freedom of assembly may only be applied if "the person in question has committed a reprehensible act when exercising his rights" (Hamilton 1998: 1). Hamilton points out this could be construed to mean that a parade organizer or participant would have acted in a 'reprehensible' manner before restrictions could be legitimately imposed.

Much of Hamilton's presentation was aimed at helping the Commission apply international human rights standards to parade disputes. Complying with the Convention meant a need to decipher when restrictions to the freedom of peaceful assembly could be legitimately applied; that is, deciphering what may count (in the eyes of the Court) as a 'pressing social need' or a 'reprehensible act'. The presentation was clearly written with the Loyal Orders in mind. While a potential challenge from the Loyal Orders was only briefly mentioned in the presentation paper, in an attached 'background paper', Hamilton went into a detailed legal analysis of the ways in which the Commission's decisions might be challenged by the Loyal Orders, mainly on the basis of the Ezelin case, and how best the Commission could justify its decisions so as to withstand the challenge.

In his main presentation paper, using the European Convention as his framework (as well as his own sense of what would be most desirable), Hamilton analyzed and problematized aspects of the Commission's 1998 determinations. He suggested that 'nonengagement' on the part of parade organizers, on its own, may not count as a justifiable reason to restrict a parade (the rights to freedom of assembly). He suggested the Commission keep the case of Ezelin in mind as he doubted 'non-engagement' would count as a 'reprehensible act'. Further, such legal reasoning problematized relying on the criteria 'impact on relationships within the community' to make restrictions, the factor most cited by 
the Commission. Hamilton pointed out that it is unclear as to whether such a factor would constitute a 'legitimate aim' as required by the ECHR.

Hamilton noted when the Commission's decision-making (and reasoning) stood on shaky ground - meaning, based on a subjective 'guessing game'. He observed:

Predicting the impact [of a parade] on relationships [within the community] (just as predicting potential disorder or disruption) is a guessing game, which in the end often boils down to the blind man's choice between two evils: -it's always going to be difficult to demonstrate why allowing a parade to proceed, should impact on crosscommunity relationships any more than a decision not to allow a parade to proceed. (1998: 2)

He also pointed to instances when the Commission was inconsistent in applying the statutory Guidelines. For instance, he noted that in some cases, it appeared as though the past behaviour of marchers was taken into consideration when making their determination, and in other cases, the Commission stated that since "the Code was not in existence when the parades under discussion took place, this was not a factor we could take into account" (emphasis in original). Further, he noted inconsistencies regarding the expectation of engagement set out in the Code. "It also seems, (as least, arguably so), that different standards have been applied in gauging whether making future parades conditional upon engagement was reasonable or unreasonable" (1998: 6).

Hamilton explained to the Commission its own role, as an institution, in the grander scheme of parade disputes. He said that the Commission has "served as buffer between the two communities". And a "successful buffer" should "absorb impact" rather than be popular or well-liked. "Indeed, attempts by the Commission to rise in the popularity stakes through the decisions it takes, would inevitably pander to a short-term agenda - it would lead, in a word, to inconsistency" (1998: 4; emphasis in original). He warned the Commission to be wary of making 'trade-offs' to appease various groups, meaning, "trying to compensate for a 
decision which has been particularly badly received by one section of the community by making a decision likely to be similarly received by the other section" (1998: 5).

Hamilton drew the Commission's attention to aspects of its determinations which may incite challenges and resistance, may further divide communities, or incite anger and distrust of the Commission itself. In doing so, Hamilton, in effect, governed the Commission's conduct. Citing one 1998 determination, he told the Commission that it "should not renege upon its own conditions". He explained: "Local resentment arising from such a U-turn will only serve to undermine confidence in the Commission and diminish its long-term credibility" (1998: 3). He also gave the Commission basic advice: "Where motives [behind a parade] are not so clear, the Commission's decision is likely to be more palatable if it does not query the purpose declared by the parade organiser on form 11/1" (1998: 4). Hamilton directed the Commission to be more consistent, transparent, and in line with legal reasoning, but he also urged the body to act in ways that would inspire, rather than harm, public confidence.

Aside from pointing out various problems, Hamilton guided the Commission on how best to use the legislation as its disposal (the Public Processions Act). He pointed out 'benefits' which came from aspects of the legislation, pointed out how the Commission could best go about rationalizing its decisions, factors it could potentially, legitimately, consider, and how it ought best to present its reasoning in determination documents, from a legal perspective.

To these ends, Hamilton suggested that the Code of Conduct "provides the Commission with the firmest ground on which to base its decisions" (1998: 7). He went on to explain: 
The speculative balancing act required by sub-sections (a), (b), and (c) ${ }^{62}$ is always something of a lottery, and decisions based entirely on criteria which, it seems, could equally be used to support contrary decisions are unlikely to inspire confidence. The Code of Conduct, however, provides a much more objective, transparent, and rational basis for making decisions.

In addition... setting aside the requirement to engage, the Code is imbued with the same principle as the European Ezelin case - that responsible behaviour should be rewarded and that irresponsibility (or what in Ezelin was referred to as reprehensible behaviour) be positively discouraged. Certainly by promoting the code, the proportionality test in Ezelin is more likely to be complied with. And on these grounds, I think that compliance with the Code of Conduct should be the primary consideration which the Commission takes into account. (Hamilton 1998: 7)

The Code was seen as the most desirable tool because it allowed the Commission to govern behaviour, rather than bend to the threat of disorder, and this was most in line with the new parades policy: "The philosophy of behind the Public Processions Act (and in the particular the code of conduct) was to encourage those on parade, and those intending to protest, to exercise self-restraint" (Hamilton 1998: 8; emphasis in original). In that the Code of Conduct would provide a more 'objective' and 'rational' set of criteria according to which to assess parade disputes (as opposed to the more subjective attempt to predict disorder, disruption, and the impact on relationships), it was thought that this would lead to greater consistency in decision-making.

Finally, pointing out that early determination documents were not consistent in their organization, layout, and format, Hamilton provided the Commission with two model layouts for its consideration. He stated that "[a]ny model (and not necessarily the ones I've put together) would aid clarity because it would pre-determine the crucial points which every decision should address and thereby provide a kind of check-list. It would also mean that the Commission's deliberations would follow a consistent pattern...” (1998: 9). Hamilton

\footnotetext{
${ }^{62}$ Subsection a, b, and c refers to the Public Processions Act Section 8(6), which are as follows: (a) any public disorder or damage to property which may result from the procession; (b) any disruption to the life of the community which the procession may cause; (c) any impact of the procession on relationships within the community.
} 
suggested a layout where the determination made can be more easily measured against the proportionality test most commonly invoked by the European Court - whether the restriction is proportionate to the aim being pursued by the authority. He suggested that determinations should be explicitly linked to the aim pursued by the Commission, and that it should be made clear which factor(s) the Commission's decision hinged on most. In addition to guiding the Commission through the legalities of how to best make and articulate determinations - meaning, to make decisions in ways that complied as much as possible with the ECHR - Hamilton also guided the Commission to present its determinations in ways that follow legal conventions. He made detailed suggestions for determination documents, such as format, numbering, paragraphing, and referencing legislative criteria, among other points.

\section{The rise of a human rights discourse and the transformation of determinations}

Ideally, of course, the Commission does not want to find itself in a position where it has to make determinations. It hopes that the community will embrace the new culture of Human Rights and use it, amongst other things, to help resolve some of the difficulties around parading disputes. (PC AR 2001: 17)

With the incorporation of the 1998 Human Rights Act on October 2 2000, the language of human rights became much more prominent in the Commission's governing discourse. There was little mention of human rights in the first and second Annual Reports (AR), while the third report now had a section devoted to the topic. The Commission stated that "it welcomed" the incorporation of the ECHR "as its area of civic responsibility is fundamentally about rights". Further, the Commission stated: "Not only is it concerned with recognising and promoting rights, but also it is involved in trying to balance rights where they come into conflict. Human Rights concerns... were at the heart of the reasoning behind the formation of the Parades Commission. ... The Commission sees Convention rights as 
something to champion" (PC AR 2001: 16). The language of human rights was now used to frame the parading problem, much as it was in the 1997 North Report.

The Third Annual Report also commented on the format of the Commission's determinations: "In its determinations the Commission explicitly sets out the reasons for imposing any restrictions on [the right to freedom of assembly and association], and demonstrate[s] how its reasoning is compatible with the Convention. The Commission makes every effort to ensure that what it does is legitimate, proportionate and necessary in a democratic society" (PC AR 2001: 16). Evident now is the legal language of human rights law; that is, framing decisions as 'legitimate', 'proportionate', and 'necessary' - language which was used by Michael Hamilton in his 1998 presentation, as well as in the 2001 NIHRC report, Parades, Protests and Policing: A Human Rights Framework (Hamilton et al. 2001). Finally, it was noted that the "Commission now builds into its determinations specific references to the European Convention, so that people will realize that it analyses these issues carefully every time it considers a parade notification" (PC AR 2001: 17). At some point in its third year then (March 2000 to April 2001), the Commission's determinations changed to a format similar to the kind used today, with human rights framing its decisionmaking. Such a change constitutes a re-investment of parading in the form of human rights. ${ }^{63}$

The new format for determinations contained three distinct sections, 'introduction', 'background', and 'consideration', plus the actual determination (the specific conditions placed on the parade), bolded and clearly laid out on a separate page at the end of the document. Every determination now followed the same general format. Paragraphs proceed in a numbered point by point fashion and relevant legislation is referenced throughout.

${ }^{63}$ For Parades Commission determinations see: http://www.paradescommission.org/parades/ 
The introduction briefly notes the legislative foundation for the Commission (the Public Processions Act), states the parade organizing body, and time and place of the parade being considered, and the need to issue a determination. Every introduction now included the following:

The Commission is conscious of its previous determinations in connection with this parade. The Commission, however, has had special regard to the nature of this parade in the light of the above Act [the Public Processions (NI) Act 1998], the Commission's stated principles (as set out in its annual reports), the Statutory Guidelines and the European Convention for the Protection of Human Rights and Fundamental Freedoms. It has also considered and evaluated all representations received and all information assembled. The Commission has subsequently concluded, considering all relevant factors, that the determination, which it now makes, is the most appropriate for this particular parade at this particular time.

After the introduction, the background section states the purpose of the parade as notified on the Form 11/1, and briefly outlines the factors deemed relevant to the specific parade being considered (the context in which it was to take place and areas of contention). Typical determinations note controversial aspects of the location or route, the state of community relations, and whether there has been any engagement or dialogue between the parade organiser and local residents. For example, on community relations, a determination may state: "The Commission is aware that this part of Belfast has seen sectarian tension and division. The Commission recognizes that there continues to be a strain on community relations in this area" (PC on Ballynafeigh 2006: 2). If relevant, the timing of the parade might be mentioned as a factor, as well as the cooperation of the parade organizer with the Commission's Authorised Officers. The background section may contain a mix of factual statements indicating the 'state of things' in the area the parade is to take place - what the Commission 'notes', 'recognizes', or is 'aware of - and governing statements indicating what 
the Commission 'hopes', 'expects', 'urges', or 'suggests' to those involved in the dispute. ${ }^{64}$ The background section usually ended with a statement as to whether the Commission deemed it necessary to place conditions on the parade and for what main reason. A typical statement might read 'the Commission has cause to believe that should the parade take place as notified (or, 'should the parade process the entirety of its notified route'), there will be an adverse effect on community relations and a potential for public disorder' (see any number of examples, for instance, PC decision in relation to Castlewellan July 12 2003, Portadown September 25 2004, Ballynafeigh April 30 2006, Downpatrick August 3 2009).

Following the background section is the 'consideration', which is the longest and now most standardized part of the determination. The consideration section indicates the main factors to which the Commission has had regard when making its decision and it also briefly re-states its decision. Most statements made here are common to all determinations, and typically, there are only a few remarks or additions made specific to the parade being considered. It is also here that the Commission made the most use of a human rights framework to justify its decision. The section begins by indicating the Convention rights engaged from both the perspective of the parade organisers, as well as of other persons, referencing those who 'live, work, shop, trade and carry on business in the affected locality'. It is noted that none of these rights are absolute. Where these rights are in competition with one another, it is stated that the Commission 'has had to undertake a balancing exercise, bearing in mind the statutory Guidelines, in an attempt to reach a determination, which is

${ }^{64}$ For example, in relation to a parade in Stoneyford on October 22 2008, the background section states: The Commission "noted that The Beeches and Stonebridge Meadows are entirely residential developments with households from both communities. It noted further that the band has previously intimidated residents in Stonebridge Meadows by processing and playing in a field adjacent to the rear of houses in the development. The Commission has strongly urged the organiser to consider the detrimental impact these actions may have had on the community relations" (PC on Stoneyford 2008: 2). 
fair and proportionate.' Human rights were now used to frame the problem (as a conflict of rights), the position of those on both sides of the dispute (as rights-bearing subjects), as well as the role of the Commission itself (a rights weighing machine).

After outlining the rights involved, the next several points shift to address the issue of engagement and dialogue. The Commission notes it has had regard to the issue of engagement and any attempts to find a local resolution, as this is 'one of the seven fundamental principles identified in the North Report'. Also, it 'will assess the measures, if any, offered or taken by parade organisers to address genuinely held relevant concerns of members of the local community'. The Commission typically made a simple statement of assessment: 'In the present case the Commission is not aware of any meaningful engagement having taken place'.

The Commission then stated its view on the parade, and it is here that minor adjustments might be made depending on the case being considered. A typical example, common to many determinations reads:

Having considered all the evidence, information and advice available to it, the Commission takes the view that it is necessary to curtail part of the parade's notified route, and it has therefore placed conditions on the parade. This decision is set against the background of continuing local community tension. It recognises the real possibility of damaging community relations with a consequent effect on the likelihood of public disorder should the parade proceed along the entirety of its notified route. Whilst recognising the fundamental importance of the right to freedom of assembly, the Commission finds it necessary to exercise its powers under section 8 of the Public Processions (Northern Ireland) Act 1998 to place restrictions on the parade.

The final few points of the consideration section, common to all determinations, again situate the Commission's decision in terms of human rights. Following Hamilton's suggestion, the 'aim pursued' by the Commission is now clearly stated. While Hamilton suggested the aim pursued be tailored to the precise factors on which the decision hinged most, the Commission used the following standardized statement in each document: 
In pursuing these conditions, the Commission pursues the legitimate aims laid down in Article 10(2) and 11(2) of the European Convention for the Protection of Human Rights and Fundamental Freedoms, of seeking to prevent disorder and to protect the rights and freedoms of others.

The legal language of 'necessity' and 'proportionality' is also now evident in how the

Commission rationalized its decisions. The final two points state:

In determining whether the conditions are necessary in a democratic society and proportionate, the Commission has regard inter alia to the criteria set down in section 8(6) of the Public Processions (Northern Ireland) Act 1998 and to its own Guidelines made under section 5 of the Act and to which under section 8 (5) it shall have regard when making a determination.

Having regard to the factors set out above the Commission considers that the conditions it now imposes are necessary and proportionate to the aim pursued. The conditions are not such as to affect significantly the individual's right to assemble. The Commission believes that the conditions it imposes strike a fair balance between the needs of the community and the rights of the individual.

As one will recall, the Commission's early determinations imposed restrictions for reasons such as when organisers failed to 'engage' in dialogue, when 'community relations' were deemed too problematic, and when the Commission believed the atmosphere was not 'conducive' for parading. Later determinations re-reframe decisions in significantly more abstract terms. Engagement was still considered, and the state of community relations noted, however, restrictions were no longer cited based on these factors alone. Instead, restrictions were now imposed with the aim of preventing disorder and protecting the rights and freedoms of others.

In the report commissioned by the NIHRC (Hamilton et al. 2001), it was suggested that the Commission could not likely place restrictions on a parade on the basis of engagement in dialogue, nor with the aim of preventing an adverse impact on relationships. However, the report noted that engagement and the impact on community relations may both be interpreted, in the Northern Ireland context, as relevant to the potential for disorder, a factor upheld by the Courts as a legitimate reason to curtail the freedom of assembly. On the 
factor 'impact on relationships within the community', the report surmises: "Like steps taken to reach a peaceful resolution, or the lack of them...it would appear that concerns about a parade having an adverse impact on community relations cannot, themselves, be used to justify the imposition of restrictions on freedom of assembly. Instead, they are relegated to being a litmus test of the potential for disorder" (Hamilton et al. 2001: 33).

Therefore, in the context of potential legal challenges, and with the impending incorporation of the ECHR into UK law, the Commission gathered and incorporated legal knowledge into how it articulated its decisions. The once clearly subjective tone of determinations, which drew on the Commission's knowledge of local politics (and the specific politics of the case considered), moved to the background in favour of an abstract legal discourse. There is little evidence to suggest that the Commission's actual mode of assessment changed. As was widely observed, the Commission's determinations do not actually analyse and weigh the human rights involved in each case; rather, the use of a human rights framework remains at the level discourse (as a rhetorical device) (Northern Ireland Affairs Committee 2001a; Quigley 2002; Hamilton 2003). ${ }^{65}$ Despite the new format, it was still not possible to discern from the Commission's ruling the weight given to each factor considered. While in his 1998 presentation Hamilton strongly suggested (with model examples) that the Commission make explicit the precise factor(s) on which the decision most hinged, this was not reflected in the Commission's later determinations. Instead, determinations became formulaic or 'boilerplated' and were "widely perceived as a 'legal gloss', bearing little relation to the situation on the ground" (Hamilton 2003: 63).

${ }^{65}$ Hamilton states: "In terms of adjudication, the Working Group believes that the Parades Commission has failed to clarify how the rights claimed in the context of parades, protests and policing should be interpreted. There is an urgent need for such clarification which would explain the key factors considered to be relevant to the protection of each of the specific rights" (2003: 63; emphasis in original). 
A government commissioned review of the Parades Commission by Sir George Quigley, announced on November 272001 and published a year later, observed several points about the Commission's determinations to date. Quigley stated that in his view:

Determinations seem primarily concerned to ensure that, if challenged, the Commission can be seen to have faithfully discharged its duty to have regard to everything to which it is obliged to have regard. But it has been put to me, from both sides of the parades argument, that the result is overly formulaic and legalistic; and that it is virtually impossible in most cases to know the weight given to individual factors or to discover in any real sense the ratio decidendi. (Quigley 2002: 180)

Quigley went on to cite another previous review of the Commission (the Northern Ireland Affairs Committee 2001-2002) which noted that "it is often presumptive to isolate any single factor and, more particularly, to make a connection between that single factor and the Commission's final determination” (Quigely 2002: 181).

With the move to a human rights framework, determinations were no more transparent in arriving at their conclusions; in fact, it may be argued that they were even less so. It is telling that after critiquing the Commission's most recent determination format, Sir Quigley noted that he was "impressed" with one 1998 determination which followed a twoday evidence-gathering session: "In its Determination the Commission made its observations on the evidence given 'as it related to the factors in the Guidelines'. The evidence related to each factor was then considered in turn and in indicating its decision, it was made clear what “it hinges most on"' (Quigley 2002: 181).

When the Parades Commission began using a rights discourse in its determinations, it was understood as an explicit shift, one that was discussed and debated. As previously highlighted, it was generally understood that the European Convention could not provide specific guidance related to the Northern Ireland context, and therefore the issue of applying 
human rights to parade disputes was complex. ${ }^{66}$ In addition to the NIHRC report, Parades,

Protests and Policing: A Human Rights Framework (Hamilton et al. 2001), the question was

addressed in numerous other conferences and reports. ${ }^{67}$

The idea of applying international human rights principles to parade disputes was

something all parties generally agreed on, to varying degrees. ${ }^{68}$ The Quigley Report notes:

It was asserted on all sides that it was rights that were at the heart of disputes. ...

There was...considerable support for the ECHR as the best available framework, although this was occasionally tempered by a hankering for adjustments (perhaps via a customised Northern Ireland Bill of Rights) which would bring the Convention more into line with the view of the world held by whoever was proposing the adjustment. (2002: 113)

The NIO review in 2000 also stressed rights as having a strong degree of consensus and that the ECHR was the way forward (cited in Quigley 2002: 75-6). To that end, the NIO suggested that the 1998 Human Rights Act be implemented earlier than planned in order to

${ }^{66}$ In recognition of the lack of applicability of the Convention, the 1998 Belfast Agreement, in establishing the NIHRC, tasked it with advising the Government on the drafting of a Bill of Rights which would be specific to Northern Ireland. The difficulty of such a task is exemplified in the date when such advice was delivered: December 2008. A Bill of Rights for Northern Ireland is, to date, still in progress.

${ }^{67}$ Three governmental reviews of the Parades Commission each discussed the issue of human rights in relation to resolving disputes (NIO 2000; the Northern Ireland Affairs Select Committee 2001a, 2001b; the Quigley Report 2002). The Belfast based think-tank, Democratic Dialogue, held a conference on 21 September 2001 titled Freedom of Expression and Freedom of Assembly: International and European Comparisons. Another conference series was held on January 26 and March 92002 as part of the Parades Commission's outreach programme, titled Parades: $A$ Vision for the Future. The conferences were organised collaboratively with INCORE and the Community Relations Council, and represented "an attempt to open up the debate on human rights and bring greater clarity" (PC Annual Report 2002: 15). Building on the conferences, the Parades Commission funded the formation of a Freedom of Assembly Working Group, which was proposed by Democratic Dialogue in May 2002 "to examine more closely the interpretation of the European Convention on Human Rights in the context of parades in Northern Ireland" (Hamilton 2003: 2). The report, written by Michael Hamilton and published in February 2003, draws from all previous reports and conferences, as well as from their own consultative process, and therefore provides a comprehensive overview of the issues.

${ }^{68}$ See Hamilton (2003: 14-15) for details of the unionist/loyalist and nationalist/republican position on the application of a rights based approach to parade disputes. 
help guide decisions on contested parades. While early implementation did not occur, ${ }^{69}$ the

NIO explained its view on the matter:

Ministers took the view that, if the courts moved early to clarify the Convention points at issue, the Commission's job could be made easier in framing future decisions and in demonstrating their underlying even-handedness and predictability. While both sides would not necessarily be satisfied with the outcome, the fact that both had called for a more rights-dominated approach would increase the PR price for resorting to violence if they lost. The move to a courts-based system would also move once and for all the suspicion that these determinations were made on political grounds by the Government, and make the task of policing determinations easier. (Mr. David Watkins, NIO, to the Northern Ireland Affairs Select Committee, 2001b: 96, cited in Hamilton 2003: 15)

It would seem then that the idea behind rushing the Human Rights Act was to allow the Commission and its decisions to gain legitimacy and acceptance, and thereby diminish resistances and challenges. Elsewhere, Dickson states that the aim of early incorporation was to allow challenges to PC decisions to be made on the basis of Convention rights (2010:

334). The ECHR would bolster the review process, which in turn, would bolster the accountability (and so legitimacy) of the Commission. After the incorporation of the ECHR, one of the Commission's determinations was challenged for being incompatible with the Convention..$^{70}$ The judicial challenge failed and in response the PC stated it "hopes that this decision demonstrates to the wider community that it makes every effort to come up with a balanced determination - a determination grounded in an awareness and respect for the rights of all” (PC AR 2001: 17). If and when a judicial review was returned in the Commission's favour (all have been to date), it was an affirmation of the Commission's procedures.

The review process is central to liberal modes of governmentality. In its third and fourth Annual Reports (AR), the Parades Commission further developed and explained its

\footnotetext{
69 See Dickson (2010: 334). The NIHRC advised against early implementation of the Act.

70 Tweed's application for Judicial Review, November 2000.
} 
review process. The PC stressed that it does not see a judicial review as negative, rather it "ensures an opportunity to scrutinize the work of the Commission and redress any errors as found by the courts" (PC AR 2002: 17). In its third year, the Commission also began including an explanation of the review process with each determination. Encouraging individuals to 'take advantage' of the review process is part of constituting desirable subjects; that is, individuals and groups who are politically active and engaged in the governing process. Government needs to foster active individuals who 'freely' participate in their own governance. Further, the review process is part of the Commission's performance as a body which is transparent, flexible, and open to change when wrong - in essence, not repressive. The use of human rights standards and the development of the review process using these standards fosters an image of the Commission as legitimate, just, and objective. Rather than appear 'heavy-handed', or dictatorial, the Commission now acts as the protector of rights and freedoms. The review process appears to enable the governed more 'freedom', 'justice', or a sense of 'power', while in actuality, power (in the Foucauldian sense) is rendered further invisible. The appeal process (in theory at least) pacifies resistance and draws individuals and groups into the liberal political process (i.e.: the new game set up with the advent of the Parades Commission).

\section{The promise and problem of human rights}

When the Parades Commission was first announced, there was much hope for applying a human rights framework to manage contentious parades. Human rights were intended to create consensus among parties and to depoliticize the parades conflict. Rather than interpret parade decisions along divided political lines, then Secretary of State Mo Mowlam stated that "actions and decisions can be determined objectively within a framework of rights and obligations to which everyone can subscribe" (Mowlam 1997: 4). Human rights principles 
were to be the great arbitrator, allowing for objective decision-making. Rights, as a frame in Callon's sense, were intended to make the elusive space and politics of parading amenable to a form of calculation. In particular, rights were deployed as a means of making 'community relations' measurable. The framework provides a set of principles and standards against which to judge all 'contentious parades'. In this way, rights work to invest, or get hold of, 'community relations' - to transpose the tacit and ambiguous into an administrative form.

A human rights framework was to transform parades into a governable object, as well as to transform individuals and groups into governable subjects. Rights-talk works to constitute active, participatory subjects enrolled in their own governance. ${ }^{71}$ Individuals and groups are imagined as bearing certain 'human rights', with the ability to claim those rights, to exercise those rights, and to protest when those rights are infringed upon. 'Rights' are harnessed as something everyone desires or ought to desire, as well as something to 'share' and negotiate with others. In this way, rights-talk works to align the interest of individuals and groups involved in parading with the aims of governing bodies. Further, it does this at the same time as it appears to increase, augment, and support the freedoms of individuals and groups.

In imagining the space of parading through the lens of human rights, and through delivering judgments in terms of rights, individuals and groups would, in theory, also be drawn to imagine the space of parading as a 'shared space'. Successful governing practices work to create and invest a particular relationship between subjects. The rights discourse is performative in this sense - its very use changes the 'conditions of possibility' for how parties in conflict may imagine themselves in relation to 'the other'. The use of rights to weave parade judgments works to re-constitute the space of parading as a 'shared space', and

${ }^{71}$ For work on rights as governance see Sokhi-Bulley (2011) and Odysseos (2010). 
so also to re-constitute relations within that space. Rights, which come with responsibilities towards others, were intended to bring 'the other' into view in way not visible before.

In her 1997 speech, Mo Mowlam’s linked 'rights' with a wider vision for community relations in Northern Ireland. She stated that "while there must be parity of rights between the communities, I hope we will also see developing parity of respect for the other's sensitivities and traditions, and a growing acceptance that cultural identity should not be celebrated in ways which may potentially offend others". The new procedures towards parades were designed to bring such a transformation about. There was hope that 'rights' would turn into 'respect' and hope for the development of a new self/other perception and mode of relating. Mowlam hoped that the new procedures would make gestures of good-will easier, and that 'sensible decisions' could be made without fear of losing ground: "In our rights-based approach, a sensible decision not to exercise a right will not make it any less real, or reduce the possibility that it can be exercised in the future" (Mowlam 1997: 5).

However, in practice, the rights framework proved problematic for the Commission. Rights were not systematically used to make different decisions, but were used as a rhetorical device to justify determinations and protect the body from legal challenges. As with mediation, governing bodies faced difficulties imposing the frame; many aspects of parading were not included in the calculation of balancing human rights (i.e.: overflow), especially those which the Parades Commission sought to govern most - tacit relations between groups, in the form of 'mutual respect', 'understanding' and 'tolerance'. As previously seen, the prescriptions outlined in the North Report go significantly beyond law. Law is not suited to measure 'accounting for the feelings of others', or one's 'willingness to understand the views of others', or to measure the health of 'community relations' more generally. The legal 
framework is not well-suited to govern parading as an field of struggle. As deployed by the

Parades Commission, rights did not work to constitute the desired subjects.

There was a tension between understanding parades as a problem of poor

community relations, and at the same time, as a problem of a conflict of human rights.

Indeed, the turn to a human rights approach to manage parade disputes was seen by some, particularly those with experience in mediation, as antithetical to a community relations and mediation approach. 'Rights' were a seen as the 'legal' route, at the expense of fostering good relationships. Hamilton's 2003 report (based on the Freedom of Assembly Working Group) states:

Disputes about parades in Northern Ireland are often described, fundamentally, as being about conflicting rights. Some, however, have regarded this analysis as secondary, instead arguing that such disputes more importantly reflect a legacy of fractured communal relationships. The policy implications of these diagnoses are often presented as being antithetical, and their respective proponents have been reluctant to embrace the other for fear that doing so would undermine their own work. (Hamilton 2003: 5)

Hamilton explained the concern with a rights-based approach:

Fears were expressed, particularly by those with experience of mediating parade disputes, that to now encourage greater recourse to legal rights and remedies could only lead to greater contention and litigation. To raise people's expectations that their rights may be enforced would seriously compromise the perceived potential for 'satisfactory accommodations' because it would effectively signal a shifting of the goalposts. To create 'winners', it was suggested, does not help people take cognisance of their responsibilities. (2003: 23)

Hamilton further cites the Evangelical Contribution on Northern Ireland (ECONI) which has argued that:

These demands for rights are mutually exclusive and allow no scope for a resolution of the situation based on compromise, negotiation, or consensus. The demand for rights - even though it may be largely rhetorical - works against the attempt to use other means of social engagement and negotiation to address the issue. These legal models - conflictual by their very nature - provide little scope for mediation, compromise or agreement. (2003: 23)

Therefore, there was concern that a rights discourse would primarily be about legal protection, 
as individuals and groups demanded their rights, as opposed to fostering compromise, mediation, and local accommodation. Rights would be taken up as a tool for legal battles creating further contention. Rights would create 'winners', rather than foster within individuals a sense of their associated responsibilities.

The thrust of the Working Group's report was to integrate a mediation and human rights approach to dealing with parade disputes. The report critiques the Commission's use of rights and offers its own sense of the necessary solution:

While ostensibly there is a consensus between parties that a 'rights-based approach' would be helpful, the Group argues that this is misleading, precisely because it cannot be claimed that a rights framework is commonly understood. To persist in applying ambivalent 'principles' will thwart the development of sustainable resolutions. Loosely defined principles can lead to their inconsistent application. (Hamilton 2003: 61)

Members of the Working Group, therefore, consider that the argument needs to advance beyond merely emphasizing that the focus should be on the rights issue at the adjudication stage. By conceptualizing the core value of human rights as being the recognition of 'the other', rights can be seen as integral to the entire process of managing and resolving conflict around parades, including mediative interventions. The goal of a rights based approach is not to impose a formulaic, prescriptive 'solution', but rather to encourage parties to both recognise each other's needs and interests and acknowledge that each has equal rights. In this light, the Working Group contends that the principles which inform any adjudicatory process can indeed must - also inform interventions aimed at promoting local accommodation. (Hamilton 2003: 62; my emphasis)

The way the Commission has applied rights is seen as problematic because it does not govern (in the Foucauldian sense). When used only as a rhetorical device and only at the determination stage of procedures, human rights do not function as a technology of subjectification. In order to re-shape what are deemed problematic community relations, in order to shift modes of relating between parties in conflict, governing must be done in the name of 'the core value of human rights', that is, the recognition of the 'other'. The Working Group, in effect, highlighted the governing value within the legal notion of human rights. 
Rights must be applied and understood, not solely as a legal measure, but as a governing tool to be deployed throughout the governing process, including mediative interventions. As the authors aptly state, the goal of a rights based approach must be to encourage, not to impose. The Working Group suggests that mediative interventions could be used to educate the parties involved - "to build an understanding of the value and meaning of rights". Based on this foundation, “mediated dialogue might then explore the 'rights and freedoms of others' how, in the particular context, are these rights being infringed, and what could be done to prevent such infringement?" (Hamilton 2003: 62). Further, the report suggests that Authorised Officers "should be given further training in drawing out the connections between interests, needs and human rights" (Hamilton 2003: 63). It is suggested that Commissioners receive similar training "in building consensus around rights" in order that the rights-based adjudicatory process "be user-friendly, informal and informed by conflictresolution practices" (Hamilton 2003: 64).

\section{Conclusion}

With the incorporation of the European Convention on Human Rights (ECHR) into UK law on October 2 2000, the Commission adopted a human rights framework to situate and explain its decision-making. With this shift, parading was re-invested in the form of human rights. Rather than impose a standard of 'engagement' and restrict parades when this standard was not met (as was the case in 1998 determinations), later determinations aimed to constitute subjects expected to govern themselves in light of their rights and responsibilities. Such subjects were imagined by governing bodies, but as the next chapter further illustrates, were not successfully constituted in practice. Determination documents became more standardized and formulaic, partly as a response to potential legal challenges from the Orange Order. The Commission's use of rights as a governing tool remained superficial and 
was seen as problematic in that it did not function as a technology of subjectification. The ethos of rights remained misunderstood by parties involved in disputes, and therefore, in practice, the Commission had difficulties fostering self-governing subjects - subjects who govern their own conduct in light of the 'other'. 


\section{Chapter Seven \\ Governmentality, Political Conflict and Symbolic Displays: Challenges, Resistances and Governing Struggle}

This dissertation has documented the primary governing practices of the Northern Ireland

Parades Commission since its inception in 1997. Based on my observations to date, governing parades has been a consistent struggle. To the present, the Parades Commission has not established itself as the governing authority on parades. Through the governing practices that go forward, parades do emerge as a kind of knowable and actionable object; parading and its relations are defined and acted on in ways they were not previous to the governing attempt. However, attempts to stabilize the object generally fail. The object is elusive, slippery, and difficult to know and so to direct. The Commission, with the administrative procedures it brings, becomes one actor in a broader field of struggle, competing among various interests to define the space of parading. The following section discusses some of challenges and tribulations of the Parades Commission and the struggle to govern struggle; that is, to shape social relations deemed problematic through the practical administration of a contested symbolic display.

Ultimately, this dissertation is a story about process. It captures an on-going attempt to organize and shape social relations in Northern Ireland through the domain of public symbolic expression. In his most recent book, Governmentality: Critical Encounters, William Walters (2012) suggests ways scholars may avoid producing studies in governmentality which make governance appear overly coherent and rational. He suggests that scholars avoid looking solely for liberal practices of government, and instead allow for seeing different forms rule, as well as seeing how different forms co-exist. He also suggests that scholars might give "more weight...to questions about processes of transformation, dynamics of 
change, and the difference made by political struggle" (Walters 2012: 74). I hope that this dissertation pushes in this direction.

The main challenges facing the Commission throughout its existence may be summarized as: resistance on the part of the Orange Order, the changing political context, and the difficulties governing a symbolic display within this context. It is useful to think about the governmental attempt in terms of what Walters has called 'patch work'. Whether speaking of technological tools which failed to work as planned as in Walters' example, or whether speaking of a governing program which failed to work as planned partly due to politics and contestation as in the present case, "the experts in question had to constantly reformulate, improvise, adjust and accommodate" (Walters 2012: 75). Walters notes that it is through this process that governing develops and advances. When governing bodies respond to emergent problems, such actions may be understood as 'patches' which are "needed to make the original project work as it was supposed to". Walters writes: "Strategies need to be studied over time. To take only a snap-shot is to miss the iterative dynamics by which the strategy unfolds, its uneven play of implementation-failure-implementation-failure-...Each patch takes the strategy in a slightly different direction. It drifts. Ultimately you reach the point where patching will no longer suffice; a new machine is called for" (Walters 2012: 76).

Most clearly exemplifying patch work are the numerous governmental reviews of the Parades Commission. The main impetus for the reviews has been the lack of consensus on governing procedures. The body has never been accepted by all parties as the best solution to the problem of disputed parades. Despite many attempted patches, it struggled to elicit the engagement of the Orange Order, and it struggled in its original and central aim; that is, to make local dialogue and resolution of disputes (local accommodation) the norm. Some of the governmental reviews were of the Commission's operating procedures 
specifically, while others were of the 'parading issue' more generally. Earlier reviews centred on improving the Parades Commission so as to gain consensus (patch work), while later reviews centred on finding an entirely new regulatory system which would replace the Commission, mainly to satisfy political interests. A new machine was called for.

Governing parades may not only be characterized by patch work. It may also be a case of governing a new object which required political experimentation. Useful to think about here is Callon's essay on framing and overflowing (1998). While I have loosely drawn on Callon's ideas in previous chapters (both the attempts at deploying mediation and human rights may be seen in terms of framing and overflowing), I make most use of Callon's ideas in this chapter where I consider the PC as a governing body more generally. In the case of parading, there is no stabilized knowledge base, such that little is certain or agreed upon: not the root of the problem, or the way it ought to be addressed (there is no agreed upon 'truth'). As such, it is very difficult to impose the governmental frame on the situation; that is, to detach the situation from the surrounding environment and set the definition of the problem, the desired outcomes, methods of assessment, and division of responsibilities. Wherever the frame fails, and its boundaries are exceeded or transgressed, there are 'overflows' which must be addressed and contained for the governing project to advance. Parading may be described as a 'hot' situation, meaning it is controversial where overflowing (leakage) is the rule.

The original governing project was understood to be a preliminary attempt, requiring monitoring and improvements as necessary (to manage the development of overflows or leaks). The Parades Commission had a statutory duty to keep its procedures under review and to make recommendations to the Secretary of State. Governing parades therefore also advanced through a process of implementation (or 'framing' in Callon's theory)-knowledge 
production-reimplementation/reframing-. ${ }^{72}$ In the present case, as the Commission gained experience with the political field, gathered research, including both lay views and expert knowledge, overflows were identified, and governing procedures were further developed. Knowledge production came in a variety of forms: the reviews of the Commission and parading, the reviews of procedures conducted by the Commission, reports by experts solicited by the Commission to help improve areas of operation (such as on marshalling and human rights), independent studies on parading, conferences organized by the Commission and other organizations, outreach work done by the Commission, and public opinion surveys conducted on parading and the operation of the Commission (one was done in 1999). The dynamics of framing and overflowing, followed by patch work, are useful to understand the governmental reviews of the Parades Commission, the challenges defining and governing a symbolic display, and the resistances and interactions with politically invested actors.

\section{Political experimentation, patch work and the struggle to enroll resistant subjects}

In his 1978 course lectures, Foucault spoke of 'the strategic reversibility' of power relations, or what he called 'counter-conduct', to mean "the ways in which the terms of governmental practice can be turned around into focuses of resistance" (Gordon 1991: 5). Power relations, while present in all human relations, do not automatically subject individuals; rather such relations are "an endless and open strategic game" (Gordon 1991: 5). The essence of Foucault's notion of power is 'freedom':

At the very heart of the power relationship, and constantly provoking it, are the recalcitrance of the will and the intransigence of freedom. Rather than speaking of an essential freedom, it would be better to speak of an 'agonism' - of a relationship which is at the same time reciprocal incitation and struggle; less of a face-to-face

\footnotetext{
72 I find the notion of political experimentation and Callon's concepts useful in that they do not, to my mind, necessarily connote of 'failure', which would suggest that the expectations at the outset were one of 'success'.
} 
confrontation which paralyzes both sides than a permanent provocation. (Foucault 2003c: 139 citied in Gordon 1991: 5).

Individuals in a field of power relations are faced with a range of possible ways of acting. The attempt to govern is not about domination, but about directing, fostering and harnessing the capacities of others to act in ways deemed desirable. In that such attempts work through 'freedom', resistance, evasion and struggle are included within the field of power.

Resistance through lack of engagement on the part of the Orange Order has made the wider governing vision for parading difficult, if not impossible, to achieve. As noted above, governing requires subjects who participate in their own governance in appropriate ways. The aim of the Commission to foster local accommodation through dialogue was significantly impeded when one of the main parties refused to enter into dialogue in the first place. While some members of the Order may have informally engaged with the Commission to settle parade disputes in their locality, the formal line of the organization has been against the Commission. Over time and through its characterization by the Order as being an 'anti-parading' body, the existence of the Parades Commission itself became the focus of opposition (rather than an opposition of regulation more generally). The abolition of the Commission became a defining, clear point of resistance, one the Order could wield to advance its political interests (for instance, see Figure 4). One might argue that the advent of the Parades Commission resulted in the constitution of an oppositional subjectivity, rather than the desired regulatory subjects (see Walters 2012: 80). Such resistance engendered some of the many reviews of parading, with the goal being at first to improve the Commission, and later, to devise a new regulatory system that would have 'cross-community' consensus. Later reviews sought to replace the Commission with new procedures that would be 
Figure 4 - 'Ulster Says No!'

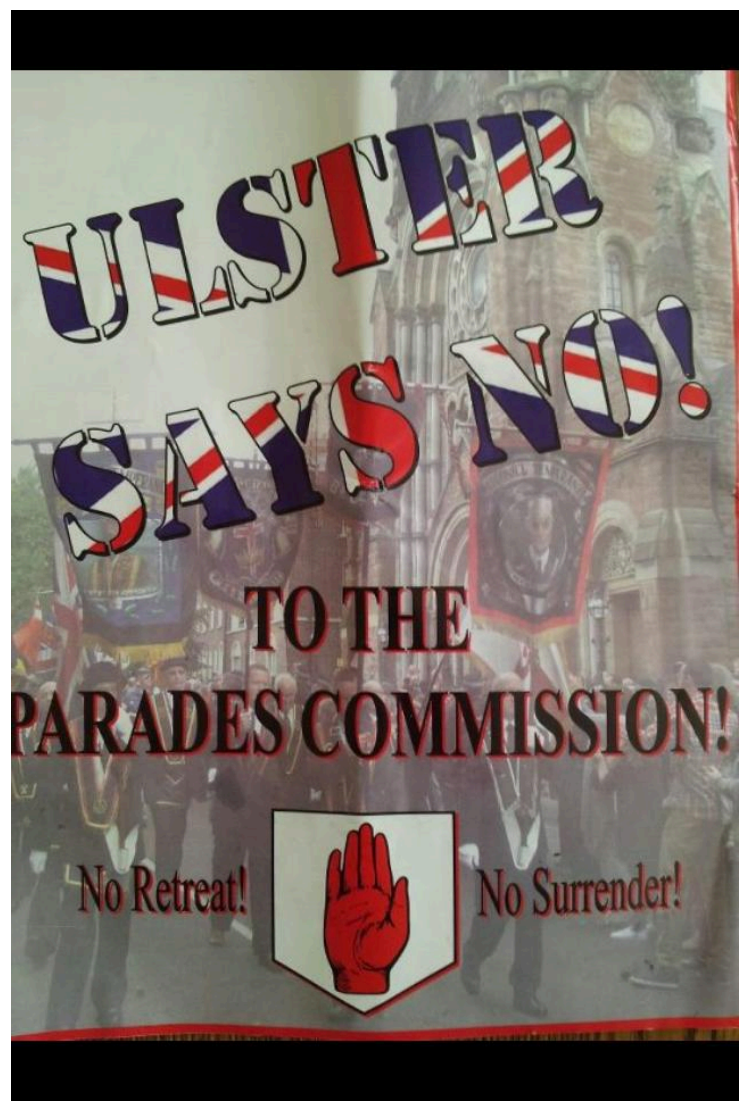

Source: Facebook page, 'Scrap the Parades Commission' https://www.facebook.com/pages/Scrap-the-Parades-Commission/132225423509352 (Accessed April 1 2013) 
supported by the Orange Order and the loyalist/unionist community. Such was the effort to enroll resistant subjects into the governing program.

The life of the Parades Commission has been tied to the ebb and flow of wider political relations. With the constant reviews of parading, the future of the body was regularly in question. There was often a buzz in the media that the Commission would soon be abolished, making it difficult for the body to instantiate itself and to maintain authority and legitimacy. The on-going reviews and the atmosphere they engendered made it difficult for the Commission to pursue its governing agenda (to encourage individuals and groups to engage with it), since it was thought by many that the body would not be around much longer. The Commission was often in the position of reminding people that, for now, it was still the authority on parades and that its determinations were legally binding. Such was the context in which the Commission had to govern, a context it noted did not help matters.

The following outlines the various reviews of parading which have taken place to date. The discussion works to provide a sense of how the life of the Commission was tied to the broader political context. Also, as discussed in the introduction, the reviews are a central part of the governing process. Which each review, views were gathered, problems were (re)defined, possible solutions were devised, and sometimes, procedural changes were implemented. The reviews give a sense of what problems and challenges the Commission continuously faced in addition to the lack of consensus - fostering engagement and local dialogue, mediation procedures, transparency in decision-making, applying human rights, band behaviour, fostering cultural understanding between groups - all are issues that continued to be worked on and discussed. More often than not, the reviews themselves failed to work as intended; that is, they failed to generate consensus on governing procedures 
and the main legislative recommendations were discarded. For the most part, the reviews only amount to attempts at patch work.

The first review of the Parades Commission was launched by the Northern Ireland Office (NIO) in October 1999, after only one year making determinations. The review aimed to find a greater consensus on the solution to disputed parades, as well as to improve the procedures for mediation. No substantial report was ever published, although the NIO did make a series of recommendations to improve the Commission's procedures in February 2000 (see Quigley 2002 for the main points). One of the key developments that appeared to come out of this review was clarification on what the Commission meant by 'engagement' in its second Annual Report (AR). The review suggested that the Commission use its second Annual Report to make the clarification. Although, given the internal discussion on engagement (during the Belle Isle weekend, chapter three), it is likely the Commission would have further defined engagement in any case. In addition, the suggestion to clarify what was meant by engagement was made by the Commission itself in the evidence it submitted to the review team (see PC AR 2000: 18).

The second review was by the House of Commons Northern Ireland Affairs Select Committee (NIAC), published in April 2001. Its remit was: "To examine the operation of the Parades Commission since its inception and to consider, within the existing framework of law and structures and in the light of the conclusions of the Northern Ireland Office's review of the Commission, how its effectiveness might be enhanced" (NIAC 2001a: para 5). The report made eighteen recommendations, based on a cross-section of views gathered through written and oral evidence. The review made suggestions on a variety of issues, such as how to improve engagement with the Orange Order, and on the need for independent observers at parades once AOs were brought within the Commission, rather than working 
through the Mediation Network. The NIAC review also suggested that the Commission include in its Annual Reports statistics on restrictions and conditions by parade type. The review noted: "Although the 'parades issue' is frequently seen as monolithic, sectarian parades, whether loyalist or nationalist, differ markedly in character, depending on their purpose". The review stated that Mediation Network identified three different types: Church parades, commemorative parades, and band parades (NIAC 2001a: para 32). Starting with its Third Annual Report (2001), the Commission's statistical accounting on parades became more complex, identifying different types of parade, which were contentious, when they took place, and the types of restrictions imposed. Rather than the more basic classification 'Loyalist', 'Nationalist', and 'Other' as the PC first began with, parades began to be further specified.

The third review was launched in November 2001, to be led by Sir George Quigley. The review was announced out of the Weston Park talks which were aimed at resolving outstanding issues stalling the implementation of the 1998 Belfast Agreement (decommissioning, demilitarisation and policing disputes). The Quigley review was largely understood as a concession to loyalists. The aim of the report was to "review the operation of the Parades Commission... and the legislation under which it was established and to consider whether there are any changes which could promote further public confidence on all sides, respect for the rights of all and the peaceful resolution of parade disputes" (Quigley 2002: 7).

The Quigley review produced a 333 page report completed in September 2002. The report made a series of what were seen as radical recommendations. As noted in the previous chapter, the Quigley review placed interpreting rights at the centre of the new procedures. Quigley's main recommendation was the dismantling of the Parades 
Commission in favour of creating two separate bodies, a Parades Facilitation Agency to serve a more structured facilitation, mediation and education function, and a Rights Panel to make formal determinations in the absence of a local agreement at the facilitation stage. Since the advent of the Commission, several problems were raised with the same body overseeing both mediation and adjudication. The main argument for separating mediation procedures from adjudication was to avoid parties entering into mediation as a 'box-ticking' exercise in order to win a favourable determination. Keeping the adjudicating body out of the mediation process would ensure that parities 'genuinely' entered into mediation, and remove any fears that the nature of the discussion/dialogue would impact later determinations.

When the report was published, the government launched a public consultation process to consider its key recommendations. The process was intended to run until January 31 2003, however, it was extended to April 2003, and eventually it was decided to leave the process open. Partly due to the government's delay in responding to the review, NIAC launched yet another review of the parades issue. The Committee aimed to consider the response to the Quigley report through taking oral evidence, and to consider the case for implementing its recommendations. In its report published in January 2005, the Committee ultimately found that keeping the Parades Commission, with certain improvements, was the best way forward (NIAC 2005).

Two years after the release of Quigley, the NIO eventually responded to the report in February 2005 (along with the responses to Quigley, as well as the report of NIAC). The NIO stated: "Government has decided that a case has not been made to make fundamental changes to parading arrangements in Northern Ireland. ... Sir George Quigley's main recommendations will therefore not be proceeded with at this time" (NIO 2005: 5). 
However, certain legislative changes were implemented arising from the findings both the Quigley and NIAC review. In Quigley's analysis, decisions on the limit of protests, like processions, equally required an analysis of the impact on the rights and freedoms of others (Quigley 2002: 222). Therefore, it was argued to be only logical that the same body deal with parade-related protests. The NIAC review agreed and suggested that the remit of the Commission be extended to include such events (as opposed to being handled by the police). In 2005, the Commission's statutory documents were amended to allow the body to make determinations on parade-related protests. As well, it was made clear that the Commission could make determinations that included parade supporters and followers.

The NIO response to Quigley came in the form of another consultation document, in this case specifically on mediation (NIO 2005). Following the recommendations of the NIAC review, the NIO stressed that mediation was the way forward and that further agreement on how best to deliver mediation was needed. The consultation document sought to collect views on potential mediation arrangements and outlined features of a new mediation model. The model stressed that mediation be voluntary, be done separately from the Commission to encourage genuine participation, and more formal procedures be developed. However, no final report was ever published (Hamilton 2007: 41).

The next major review was announced in February 2007, called the Strategic Review of Parading in Northern Ireland (SRPNI, hereinafter, SRP or Ashdown review), to be chaired by Lord Paddy Ashdown. The Ashdown review was launched in the wake of the St. Andrews Agreement on the devolution of power from the British government to the Northern Ireland Assembly. ${ }^{73}$ The result of the Agreement was the restoration of the

\footnotetext{
${ }^{73}$ The Northern Ireland Assembly was formed out of the 1998 Belfast Agreement. It was suspended several times, and governing Northern Ireland was taken over by the NIO, the British government department headed by the Secretary of State for Northern Ireland.
} 
Assembly and a commitment to power-sharing among political parties. The "successful establishment of agreed institutions in Northern Ireland in 2007" was thought to represent "a historic opportunity for change". The new political context was thought to hold a "real, and possibly unique, opportunity to make progress on outstanding disputes around territoriality and parading" (SRP 2008: 12). Rather than review the operation of the Parades Commission as other reviews has done before, the review was of parading more generally (more in line with the North Report).

A 65 page interim report was made available in April 2008. The interim report suggested new arrangements for the management of all public assemblies. The overall philosophy of the report was to allow for greater decision-making to occur at the local level - it was to be about "re-engaging democratic politics" (SRP 2008: 18). In keeping with the idea of devolution, the overall management of public assemblies would be transferred to the Office of the First Minister and Deputy First Minister (OFMDFM), headed by a secretariat (as opposed to the Parades Commission whose members were appointed by the Secretary of State). However, local councils would be the front lines. ${ }^{74}$ The review body sought to harness the governing capacity of local authorities. Parades would be notified to local councils who would be responsible for arranging local dialogue between parties in dispute. The report stressed: "[T] he Strategic Review believes that it should be fundamental that conversation, dialogue and local agreement become the normal way of doing things. A simple phone call or conversation can, more often than not, resolve differences and difficulties before they escalate and entail recourse to the mediation or adjudication processes we have devised" (SRP 2008: 18). If local dialogue failed, local councils would start a mediation process through an OFMDFM list of mediators. If mediation failed, the council would refer the

${ }^{74}$ Local councils are made up of elected political representatives in each city/district and are responsible for running select local affairs. 
parties to a three-person Adjudication Panel assembled by the OFMDMF. At least one member would have legal expertise. The review body stressed that a rights based approach provided the best framework to make consistent decisions about disputes (whether at the negotiation, mediation, or adjudication stage) (SRP 2008: 20).

Nationalists rejected Ashdown's proposals, arguing in favour of keeping the Parades Commission, while loyalists/unionists were broadly supportive of the new arrangements. Ultimately, there were political disagreements over the findings and the review body never produced a final report. The Democratic Unionist Party (DUP) claimed that Sinn Féin (SF) had at one point agreed to the end of the Parades Commission, but when devolution of policing and justice stalled, Sinn Féin backed away from that position. According to media reports, Sinn Féin wanted the immediate transfer of powers for policing to Northern Ireland, while the DUP argued "that can only happen where there is 'community confidence' among unionists" (BBC News, January 30 2010). The DUP then made the abolition of the Parades Commission a requirement for the transfer of policing (as a way to produce such confidence), while SF argued devolution should proceed regardless of the parades issues. The issue of devolving policing came to a head in 2010, with the management of parades assuming centre stage as the main issue leading to breakdown in negotiations over devolution. The power-sharing executive was near collapse, which led to all-party talks at Hillsborough Castle. ${ }^{75}$ The negotiations lasted for 10 days and eventually produced an agreement between the DUP and SF on the devolution of policing and justice (announced at midnight on February 4). Part of the agreement was another review of parading. It was announced that:

${ }^{75}$ Talks included the British PM, the Irish Taoiseach, and representatives of the two largest political parties, the DUP and SF. 
The First Minister and deputy First Minister have agreed to set up a co-chaired working group comprising six members, appointed by them, with experience of dealing with parading issues which will bring forward agreed outcomes which they believe are capable of achieving cross community support for the new and improved framework. This work will begin immediately and will be completed within three weeks. (OFMDFM 2010: 5)

Like the Quigley review (2002) and the Strategic Review of Parading (2008), the

Hillsborourgh review was also about finding a solution to disputes that had the support of the Orange Order and the unionist community.

The Working Group produced a Draft Public Assemblies, Parades and Protests Bill (Northern Ireland) for consultation (hereinafter Draft Bill or Bill) (OFMDFM 2010). The proposed arrangements were similar to those made in the Ashdown report in that two new bodies would replace the Parades Commission. There would be an 'Office of Public Assemblies, Parades and Protests' (“OPAPP”) created within the OFMDFM, which would manage the bulk of the administration of parades, and an Adjudication Panel, referred to as the Public Assemblies, Parades and Protests Body ("PAPPB”). The procedures emphasized first finding a local agreement through dialogue, and then if needed through formal mediation, both of which would be organized by the OPAPP. The parties would then as a last resort be referred to an Adjudication Panel. Once published, the Bill was subject to a period of public consultation, through which it was critiqued on several fronts.

One of the main criticisms of the Bill was that it was too sweeping in its definition of what counted as a 'public assembly'. The definition of 'public assembly' was elaborated to include not only processions and protests, but also 'public meetings' which were defined as 'a meeting of 50 or more persons, held in a public place, and which the public, or a section of the public, are invited to attend' (OFMDFM 2010: 11). The police argued this meant that even backyard barbeques of 50 people would need to apply for notification (BBC News, August 12 2010). The Parades Commission too argued that the Bill 'widened the net' to 
include a focus on many events not intended to be included in the legislation, such as open air gospel meetings, sporting events, race meetings, open air concerts, park festivals and neighbourhood events where the numbers exceed 50 people (PC 2010: 16).

The Commission also did not think the Draft Bill improved upon the procedures already in place and it cautioned against developing regulatory procedures according to political interests. In its response to the Draft Bill, the PC wrote:

It is sometimes stated that the demise of the Parades Commission as a body is required to satisfy the demands of a particular section of the population. Therefore, what follows after the Commission matters little. It is also sometimes stated that others with no interest in the life or death of the Commission may be prepared to accept its passing by way of a 'trade-off', in return for what they may see as 'political gains'. Where this is required to stabilize or bed down the peace process, then one can see the argument for such an approach. ...

However, the Commission suggests caution in substituting a body such as the Commission for another system which delivers only by being an alternative rather than an improvement. (PC 2010: 6-7)

While the government agreed to revise the definition to more narrowly capture the intended target, like Quigley and Ashdown before it, the Draft Bill was never implemented due to political disagreement. The Orange Order, in the end, did not support the Bill. Therefore, through all of the reviews to date, the Parades Commission has remained the body responsible for parading.

While the reviews posited different administrative procedures, the broader vision and policy approach generally remained the same. Like the original review, the North Report, both Quigley and Ashdown explained the problem as one of difference; a clash of cultures emerging from historical conflict. All pointed to the problem of perceptions and a lack of understanding between groups, particularly of each other's culture and traditions. All put forth a similar vision; that is, a vision of "an inclusive, open, tolerant, compassionate society whose members have the self-confidence to embrace diversity and thrive on difference" (Quigley 2002: 10). The values of democratic societies were reinforced. Ashdown noted that the days 
of intimidation and violence were over: "In democratic societies, disputes should be resolved through peaceful dialogue, or, where required, through the democratic political system" (SRP 2008: 18).

The reviews are attempts to stabilize the object of government via knowledge production, to act on it with more precision and with more effective procedures/strategies. They are an attempt to make the administration of parades run more smoothly, without contestation. In Callon's theory (1998), the reviews attempt to map out the externalities and work to 'reframe' the situation. While the original framing did not include protests, the overflow was identified and the situation reframed. In that the reviews gathered 'views' from a range of individuals, groups, and politically interested organizations, knowledge production involved more than just 'experts', but many different actors played a role. Ultimately, governing is a dialogical process, a back and forth between governors and the political field.

\section{Elephants and turkeys also need apply}

The reviews and the continuous reflections on parading and the work of the Commission also reveal certain challenges in governing a symbolic display when it is specified as a problem of 'community relations'. Such challenges are evident in the difficultly making transparent determinations, and in defining the object of government. The issue of transparency in decision-making is one that plagues the Commission throughout its existence, and it is a theme of the many reviews. Due to the lack of transparency, the Commission was charged with making decisions largely based on public order concerns (Quigley 2002: 20). Several of the reviews tried to rectify the problem of transparency (patch work) through a more robustly applied rights based approach. Indeed, the broader discussion around human rights may be understood as a patch to the problems of overflow - transparency, consistency, and legitimacy in the Commission's decision-making. 
In practice, however, as illustrated in previous chapters of this dissertation, the Commission relied on local knowledge of the political context in order to make decisions.

Authorised Officers were the main source of information, not lawyers with legal knowledge. The Commission governed through mapping 'contentious' or 'sensitive' landmarks in relation to parade areas and routes, a well as by looking to past events. The way decisions were actually made was difficult to put into a rationalistic framework. Ultimately, a legalistic application of rights principles (as applied by the Commission or as envisioned in the reviews) was not, and would not be, helpful in rendering the symbolic space of parading governable. Specified as a problem of 'community relationships', governing bodies would still need to know the detailed politics of place in order to govern - the 'sensitive' landmarks, behaviour and symbols which might cause offence, that which might provoke, in other words - attitudes, behaviours, emotions and relations. More than anything, parades were governed through this kind of coded language; 'contentious', 'sensitive', 'tensions', etc., which signaled the attitudes, emotions, and relations relevant to the particular case.

A good example of the above point is in the SRP Interim Report (2008), which developed a new parade notification form. While the report advocated making parade decisions by weighing rights, words such as 'sensitive' do a lot of practical governing work. ${ }^{76}$ The draft notification form asks parade organizers: "Are you aware of any public concerns in relation to the proposed assembly, or any difficulties or tensions associated with this location or route in the past?" (SRP 2008: 38; my emphasis). If yes, the organizer must "state the

\footnotetext{
${ }^{76}$ With the Ashdown review, there was a shift in language from describing parades and location as 'contentious' to using the term 'sensitive'. The word 'contentious' only appears twice in the entire document, and one instance is in the terms of reference (to "examine why certain parades are considered contentious"). In the subsequent report, the word 'contentious' is replaced with 'sensitive'. The 2010 Draft Bill also uses the word 'sensitive' rather than contentious. My sense is that this was a deliberate shift away from acknowledging or making manifest conflict. 'Contentious' is a word that connotes division, controversy, and fighting much more so than 'sensitive'.
} 
nature of any public concerns of which you are aware in relation to the proposed assembly (such as tensions associated with this event in the past)". Followed by: "List each known sensitive location along the route of or in close proximity to your assembly and the actions identified to take account of the associated sensitivities". There are then two columns to be completed, one titled 'sensitive location', and the other titled 'action proposed' (SRP 2008: 39; my emphasis). The form relies on coded language such as 'sensitive' and 'tensions' in order to know how and where to intervene in the parade. In addition to governing through such coded knowledge, the form guides organizers to be self-governing in that it requires organisers to acknowledge specific points along the route as 'sensitive' and to document specific actions that will be taken to manage these 'sensitive locations'.

Defining the object of government within a legal framework was continuously problematic for governing bodies. 'What is a parade' and what ought to count in parade legislation was a question that emerged with regularity. It was clear from the beginning that the Parades Commission was intended only to regulate certain kinds of events, but defining these kinds of events within a legal framework proved tricky. When the Public Processions Act was first enacted, there was no real effort to define or clarify which specific processions were to be regulated. Over time, there followed increasing attempts at definition, transparency, and standardization. In Ashdown, following from the widened remit of the Commission to include protests, rather than regulate 'public processions', the object was now broadened to 'public assemblies'. The report defined public assemblies as "an assembly in a public place of 15 or more people, all public processions and all protest meetings" SRP 2008: 25). Ironically, as seen with the Draft Bill (OFMDFM 2010), attempts at further definition led governing bodies away from the narrowly intended target. 
The problem of defining the object of government is also apparent in instances where organisers of 'other types' of events - events which were clearly not the desired focus of the Commission - were caught in parades legislation. Vintage car rallies in particular raised the issue of whether such events should be exempt from notifying to the Commission (and filling in the same 11/1 form). These incidents were widely covered in the local news media. In October 2008, two elephants from a visiting circus were led on a walk through Bangor town centre. The Belfast Telegraph reported, "Two circus elephants may have to 'pack their trunks' after being reported to the Parades Commission. Mia and Mamba, from the Sydney circus, found themselves in trouble with the law after the PSNI branded their stroll through Bangor town centre an illegal parade" (October 22 2008). Apparently, a member of the public complained about animals on public streets out of concerns for public safety, and the police responded using parades legislation (County Down Spectator, October 30 2008).

The media played up the ridiculousness of the situation. One cartoon in the Belfast Telegraph showed an elephant wiping away tears, while a sympathetic Orangeman stood beside him with the thought bubble "You not allowed to parade either big lad?" (October 23 2008; see Figure 5). Regarding a Santa Claus parade in Belfast, one article quipped:

Santa Claus is coming to town on November 15 - provided he isn't re-routed! Santa - who will be touring the world on Christmas Eve night - has had to apply for permission from the Parades Commission to travel the few hundred yards from the City Hall to Castle Court in Belfast... There are, however, calls that the Commission should be given the sack for including a Santa clause in the legislation. For example, David Jones of Drumcree fame... said: "I'm not really surprised. When you consider that applications have to be sent in for circus elephants parading in Bangor. (Belfast Telegraph, November 1 2008)

While the media had a field day with such incidents, unionists used them to mock the Parades Commission and to declare the body a further waste of resources. In another reported incident involving a Christmas turkey walk, the head of the Orange Order in Portadown accused the Commission of wasting time and called on it "to forget about 
Figure 5 - 'You not allowed to parade either big lad?'

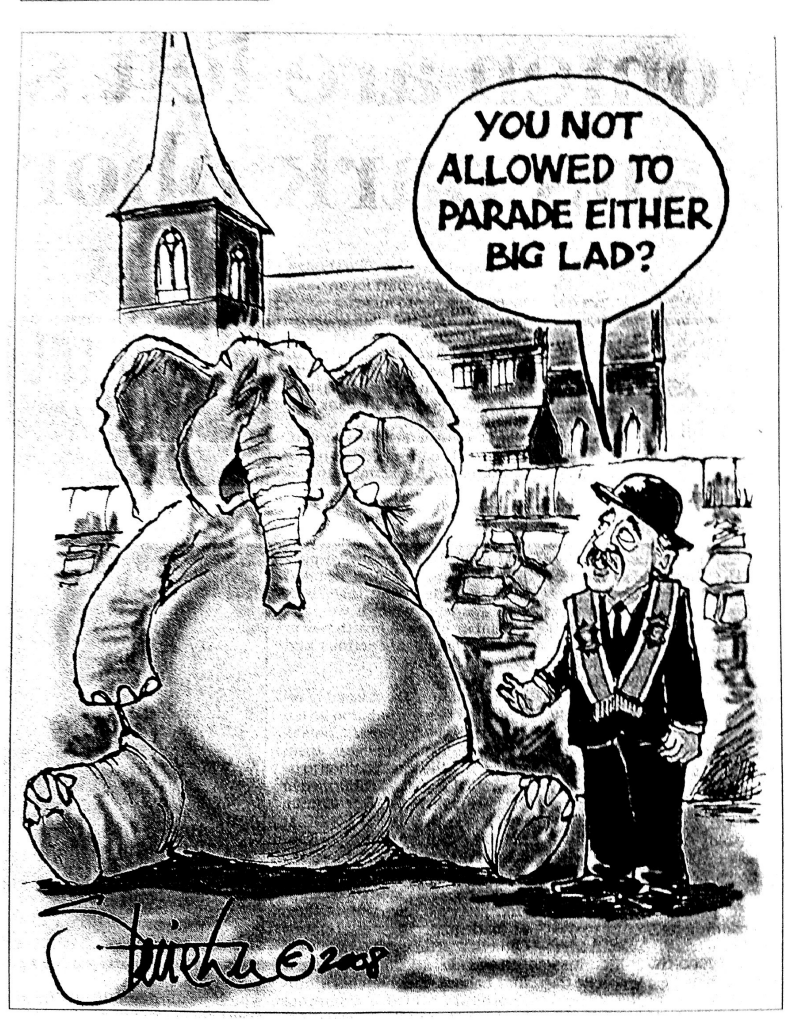

Source: Belfast Telegraph, October 232008. 
banning Santa Claus, turkeys, wheelie bin races and circus elephants from the public highways and get on with the job of resolving the Drumcree situation". The incidents put the Commission in a defensive position. The same article reported that a spokesperson for the Parades Commission stated that the body was too busy dealing with the contentious RIR (Royal Irish Regiment) parade in Belfast to worry about "these light-hearted events like Santa, and anyway these events are simply a matter of form to apply to the police" (Belfast Telegraph, January 5 2009).

The news coverage of such incidents reveals the difficulties in marking the difference between 'these events' and the kind of events that were to concern the Commission. Many news articles do not state why such events should not be included; rather, it is assumed as common knowledge - everyone knows elephants, turkeys, and cars are not the intended focus of the Commission. In some media reports, the differences are put into words - these 'other' events are described as 'non-contentious', 'light-hearted', 'non-religious', 'nonpolitical', while the Commission is for regulating 'contentious' parades and 'bands with banners'.

Most telling is that the problem was often characterized as a need for more 'common sense' on the part of the Commission. On the exemption of Old Vehicle Clubs, one paper reported: "Down District Council has called for more 'common sense' in the Parades Commission's rules and regulations.... Cllr Anne McAleenan remarked that including the Association [of Old Vehicle Clubs] within Parades Commission requirements was part of the 'nonsense' of the legislation". Cllr Eamonn Mac Con Midhe agreed, stating: 'These types of events that don't cause contention should not have to go under the same legislation. The Commission should broaden the requirements and use more common sense,' he declared" (Mourne Observer, October 29 2008). When a charity walk was also told by the police that the 
Commission needed to approve the walk, the organiser told the Banbridge Chronicle that it "seems just crazy". He went on to say "The Parades Commission is really for bands with banners and we won't even be collecting money on the way...”. In response, the Commission explained "It's just the way the legislation is written... It doesn't matter that the event is non-religious or non-political" (Banbridge Chronicle October 28 2009).

Regarding the possibility of exemption, the Association of Old Vehicles Clubs met with then Chairman at the Parades Commission, Roger Poole, and "they were informed that the legislation had never intended to include old vehicle events" (Mounre Observer, October 29 2008). The Association put the matter to the Strategic Review of Parading, however, the review body found that no exemption for vintage cars could be made under the present law (Larne Times, October 30 2008).

There is something noteworthy here about the attempt to govern a symbolic display through a legal framework which results in all types of public assemblies being caught in the regulatory net. These 'other types' of events are externalities not included in the original calculation. The overflow, that which exceeds the governing frame, indicates the difficultly of specifying the target object. While there was a tacit public agreement on which events were in need of regulation and which were not, specifying such events within the governing framework was problematic. With the use of a legal framework, all assemblies in public space were treated in the same manner regardless of their signification - resulting in a whole debacle over marching elephants needing to apply to the Commission in order to walk the streets for exercise during a town circus. Really, in that the aim of government was to transform political relations, it was the symbolic aspects of parades that required attention not all physical marching per se. That said, the vision of governing bodies in Northern Ireland was to depoliticize parading and to regulate public displays as they would be 
regulated in consensual democratic societies. Part of the governmental strategy was to make standard rules and regulations, which was done by deploying internationally accepted human rights principles, rather than address the exceptional.

\section{Resistances and interactions: The new field of struggle}

The PC may not have been successful in what it set out to achieve, but it does change or transform the conditions of possibility for political struggle around parades. The Commission and the broader governing project brought with it new discourses and administrative procedures which shaped the terms of the discussion around parading. It became common in the political and public imagination to think about parade disputes as problems of rights and relationships, rater than problems of public order. By the time of the Quigley review, it was also, according to Quigley, generally accepted that independent thirdparty intervention was a "fact of life" and that some regulatory body was needed to deal with parades (2002: 110). However, rather than re-organize parading and produce the desired regulatory subjects, the Commission became one actor in a broader field of political struggle. Individuals and groups, each with their own interests and agendas, reacted and responded to the Commission, and the new relationship created with the police, who were now enforcers of determinations rather than decision-makers. Political contestation was not effectively muted; rather, to a certain extent, the focus shifted to the Parades Commission and its decisions.

In addition to resistance at a broader political level, there were acts of resistance at the level of administration. On parade notification forms, in some cases the name and/or contact details of the parade organizer would be missing or illegible, or the name of stewards would be made up. The administration process was used by different groups to serve their political interests. In some cases, when a parade organization was not happy with a 
determination, a form of protest was to keep submitting notifications to parade. ${ }^{77}$ Notifying parades on a weekly basis bogged down the Commission's administration and forced it to keep issuing determinations; that is, to keep dealing with the issue. The point made was that the group and its demands were not going away. There also began to be parades and protests notified with the express purpose of protesting the Commission's decision in relation to a particular parade. Ironically, the Commission found itself issuing determinations for parades and protests organized to protest against it.

For example, the Portadown District LOL No 1 notified to parade in Portadown on July 222007 for the purpose stated as: 'To Complete Return Parade from Morning Worship Denied by Parades Commission Since 1996'. The group notified for a similar purpose a number of times. For a parade on May 4 2008, the purpose was stated as: 'Return Parade to Carleton Street Following Morning Worship at Drumcree Parish Church Prevented by Parades Commission in July 1998' (PC on Portadown 2007, 2008). The Portadown District LOL No 1 notified parades with the same purpose on other dates, such as May 11 and November 2 2008. Similarly, the Pride of Village Flute Band, Stoneyford, notified a parade on November 52008 for the stated purpose of: 'Protest Parade Against the P.C.' (PC on Stoneyford 2008).

With the 2005 amendment to include protests within its remit, the Parades Commission now provided an official channel for protests which today are a significant part of parading. The formalization of protests, either against the PC or as the grounds for struggle between groups, is one of the consequences of the governmental project. In the case of a protest notified by the Keady Residents Associated to take place in Keady on 12 July 2009, the purpose was stated as: 'Protest Against Orange Order Decision To Cancel

\footnotetext{
${ }^{77}$ For instance, such tactics were used by parade organizations in Portadown and Stoneyford.
} 
Their $4^{\text {th }}$ July Parade, Which Was Agreed Where One Band Could Go To Church - Now They Want A Number Of Lodges To Parade On $12^{\text {th }}$ of July - Thus Causing Community 'Tensions' (PC on Keady 2009).

The Commission and its determination documents became part of the political struggle, as each group used the Commission's procedures to their advantage. A protest against a parade would sometimes be notified, ensuring that objections were recorded, and then called off when the Commission's determination was issued in the manner desired. Also, with determinations imposing certain conditions on parades, it enabled groups to police each other. Contraventions of the Commission's rulings became another tool to wield in the political struggle. On blogs, in the media, and at events, determinations were taken up to argue how they were contravened, pointing to elements such as the music played, the manner in which it was played, undue stoppages, and offensive flags or banners flown. ${ }^{78}$ Policing parades and prosecuting when determinations were breached became a focus point in disputes. Legally prosecuting for breaches of determinations was difficult due to the lack of clarity in the Commission's statutory documents. ${ }^{79}$ Much of the criteria in the Code of Conduct (ex: "marching must be dignified") was too vague to make a legal case. There was a general lack of consequences for perceived breaches of determinations. The Commission held the line that prosecutions were up to the police and Public Prosecution Service.

Determinations themselves became the subject of contestation. Decisions were subject to political judgement from both sides of conflict, which often played out in the media. Politicians, parade organizations, and representatives of residents' groups spoke out for or against determinations depending on their interests. In at least one case, protests against the ruling were held at the Commission's office and threats were made in the media

\footnotetext{
${ }^{78}$ For example, see the blog by McKay (2009).

79 Personal communication with PSNI officer in July 2009.
} 
that the parading group would defy the decision (Newsletter, June 15 2011). Depending on the context, determinations could spark public reaction and have political consequences, as well as lead to increased violence and public disorder at events. Determinations were made by the Commission with the potential political consequences in mind.

Over time, certain rulings came to be expected in relation to certain parades and locations. In these cases, the result was less political upset as the situation settled into a sort of pattern. However, when the Commission made a different determination, one that was unexpected, the body would often face political backlash, criticism, and consequently a rise in conflict among parties to the dispute. In 2013, a new ruling on an Orange Order parade in North Belfast on July 12 (the parade route was restricted for the first time), led to several days and nights of serious rioting. The situation escalated to the point where the police chief requested that the Secretary of State impose a six month ban on all parades.

Governing discourses were also appropriated by the governed in unintended ways. The way rights were taken up, as a further chip to play in the political game, was not the intended or desired outcome of the rights discourse. In addition to reflecting the difficulties governing a symbolic display, it reflects the difficulties of governing in the context of political conflict, where historical identity groups and their modes of relating are entrenched. Governing discourses were appropriated within an already on-going game of political struggle. In the PC response to the 2010 Draft Bill, it critiqued the way the Bill deployed the discourse of human rights as a 'new' approach: "While this is to be welcomed, the approach is not new and it may be misleading to suggest otherwise. The Commission has been working to promote and balance human rights since its very inception." The Commission then went on to note the problem with human rights to date:

We should point out...that protagonists too often and too simplistically believe that if there is a robust adherence to a human rights framework and principles, then this 
will mean 'inevitably' that their 'position' must win through. They believe it because they understand that they have human rights and expect to see a vindication of those rights in the face of challenge or opposition from the 'other side'. Both 'sides' claim that they want decisions to be made which are firmly based on a recognition of human rights. Unfortunately, they also tend to believe that the application of any rights based approach translated into an almost exclusive focus on 'their' human rights. In this context human rights is not part of a discourse which seeks to promote tolerance, respect and understanding but rather a card to be used to trump the cards of the other players. (PC 2010: 2-3)

In essence, as the previous chapter discussed, 'rights' have not effectively constituted the desired subjects. That is, the discourse of rights has not effectively instilled within individuals that rights come with responsibilities, or instilled the ability to recognize the rights of others, and to accept that one's rights may not always be exercised for the sake of the rights of others. The Commission recognized that it is partly due to a failure of government: "Perhaps there has been a failure to articulate this sufficiently into a wider community debate and education by all those bodies tasked with promoting mutual understanding and human rights discourses including, but by no means only, the Commission" (PC 2010: 3).

\section{Conclusion}

While previous chapters of this thesis have focused on the attempts made by the Commission to constitute the spaces and politics of parading as an object of government, this chapter has centered on the challenges and resistances faced by the body in advancing this project. Through outlining the many reviews of its procedures, the discussion illustrates the ways in which the Commission's governing processes were shaped by political processes (i.e. official politics). It also shows the difficulties in governing a symbolic display through a legal framework, when the aim of government is to re-shape political relations. Is it right to say that the Commission has been unsuccessful in its task? Yes, because its desired results have not come about, but that is not to say that the intervention has made no difference or that nothing has changed. As evident in the interactions between the Commission and the 
various groups involved, the advent of the Commission has changed the conditions of possibility around parading; it has become part of and has shaped the field of political struggle and opened up new possibilities for conduct. 


\section{Conclusion}

[T] he next and most important piece of the parading jigsaw is dialogue between those who seek to express their culture through parading and those who object to the manner of this expression. -The Parades Commission (Annual Report 2009: 2)

With the parades crisis in the mid-1990s and the subsequent North Report (1997), governing discourses in Northern Ireland have continuously stressed that 'dialogue', 'shared understanding', and 'respect for human rights' are the solutions to the parading problem; a problem characterized as both troubled 'community relations', and as a conflict of rights. This dissertation has argued that the assemblage of regulatory elements directed at parading since the mid-1990s is more a strategy of government than a solution to the political problems in Northern Ireland.

To that end, this thesis has been concerned with the governing strategies and tactics deployed by the Northern Ireland Parades Commission since its inception in 1997. In Northern Ireland at present, there is a concerted attempt to govern struggle through the symbolic; that is, to govern what are deemed to be conflicted social relations through managing and administering the use of signs, symbols and symbolic displays. I have argued that in the context of the developing peace process and the parades crisis in the mid-1990s, parading became one such target. Once understood as a problem of 'community relations', a clash of cultures, and a problematic expression of cultural 'identity', the strategies and tactics directed at parading shifted; rather than prohibit or restrict parades through public order laws, governing bodies attempted to intervene in and manage how parading was practiced and the tacit, fluid, ephemeral symbolic politics it entailed.

In chapter one, I discussed my theoretical and methodological approach. Foucault's study of governmentality and the subsequent development of his work by others has provided the foundation for this thesis. In addition, I supplemented a governmentality 
analytic with a few key concepts: investment in forms (Thévenot 1984; Curtis 2000, 2001; Desrosières 1990), framing and overflowing (Callon 1998), and related to the latter, patch work (Walters 2012). The concept of 'investments' usefully captures the ways in which the indeterminate comes to be imbued with particular attributes, such that the social world appears defined and ordered. The idea of 'investments' signals the practical and technical work that governing bodies must do in order to intervene in and manage some aspect of social life. Both the dynamics of framing/overflowing and the idea of patch work usefully add to governmentality by stressing the ways in which governing projects are unstable, fragile, subject to experimentation, adjustment, and sometimes failure. Such concepts are especially useful in analyzing the government of parades in Northern Ireland, where contention is the norm and official politics significantly interacts with the attempt to govern.

Chapter two worked to set up the political problem that is the subject of this thesis. I sought to illustrate how, in the mid-1990s, restricting parades through public order laws significantly gave way to governing parades by a Parades Commission. With the advent of the Commission in 1997, public order concerns were taken up within governing practices which primarily attempted to encourage, entice and direct the conduct of individuals and groups. The governmental aim was to re-shape social relations and conduct deemed problematic such that events could occur without conflict or disorder.

In chapter three, I reviewed the establishment of the Parades Commission and outlined the heterogeneous assemblage of elements which were directed at the spaces and politics of parading. I showed how, through investments in forms, the assemblage produced the central object it sought to govern, 'contentious parades'. In this case, the informationgathering forms used by the Commission worked to invest the grounds of parading by sorting and classifying events in terms of 'contentiousness'. This chapter also discussed the 
Commission's Code of Conduct, which was intended to apply to all notified parades, regardless of contention. I illustrated how, through the Code, governing parades was an attitudinal and behavioural project.

Once stamped 'contentious', parades were subject to two primary governing strategies and tactics: mediation and making determinations. In chapter four, I argued that mediation was a form of knowledge and tactic of power which worked to constitute parading and local symbolic politics as a governable domain. Mediation provided a framework through which governing bodies could problematize and diagnose social relations in Northern Ireland, and it provided a means to organize and reform such relations. I also suggested that mediation may be usefully thought of in terms of the dynamics of framing and overflowing (Callon 1998). While mediation was intended to render parade disputes calculable, it was not easily applied to the Northern Ireland context. I showed how governing bodies worked to adapt, adjust, and develop the frame to account for externalities (such as an unwillingness to enter into mediation in the first place).

In chapter five, I analyzed the knowledge practices that went into making determinations. I argued that the Parades Commission relied on already-constituted ideas of territory and space; 'parading' could not be thought without mapping practices which identified particular locations in Northern Ireland as either Catholic or Protestant. This chapter further showed how the Commission worked to map local symbolic politics and to situate parading within the everyday spaces of 'the community'. In doing so, the field of government expanded to include a wide range of social conduct now seen as connected to how parading takes place. I also analyzed the practical and technical administrative procedures through which determinations were made and through which parades were 
monitored and reported on. I argued that such knowledge practices and administrative procedures worked to constitute parading as an object of government.

Both chapter four and five illustrate that governing a symbolic display was partly done through highly symbolic means. The Parades Commission relied on and harnessed forms of tacit knowledge in order to govern. The body also relied on implicit language in using words such as 'contentious', 'sensitive' and 'tensions' in order to constitute the problem space in which it was to intervene. As some scholars have suggested, and as this case has shown, the practices of government may not always advance through expert, scientific or statistical knowledges (Garland 1997; Singer and Weir 2006).

In chapter six, I illustrated how the field of parading was re-invested in terms of human rights. With the incorporation of the ECHRs on October 2 2000, the Commission adopted a human rights framework to explain and justify its decisions. Disputes were to be understood as a conflict of rights, those involved in disputes were conceptualized as rightsbearing subjects, and the Commission itself was constituted as a rights-weighing machine. The chapter also worked to show how governing does not happen in isolation from the wider field of struggle. Rather, the Commission's governing practices were shaped by the challenge posed to it by the Orange Order. Finally, the discussion showed that the way in which rights were used by the Commission did not actually change how the Commission calculated parade disputes. While rights were held to be the solution to the parades problem, the legal use of rights did not function effectively as a technology of subjectification.

Finally, chapter seven focused on the challenges and resistances faced by the British government and the Parades Commission in the attempt to govern struggle through the symbolic. I discussed the numerous reviews of parading and of the Commission since its inception. The reviews exemplified the ways in which governing advanced in relation to 
official politics, and through processes of political experimentation and patch work. This chapter also highlighted how 'other' types of events were unintentionally caught in the regulatory net. I suggested that when the aim of government is to foster new political relations, governing a symbolic display through a legal framework is problematic. I concluded that while the Commission did not succeed in its intended aims, it nevertheless shaped the field of political struggle and opened new possibilities for conduct. The Commission became a rallying focus point for resistance on the part of the Orange Order and created a new space for struggle between groups.

\section{Calculation vs. politics}

Barry notes that in sociology, an opposition is often drawn between calculation and politics. "Calculation is thought to reduce the space of the political and to limit the possibility for disagreement. When situations become calculable it is taken to indicate the fact that political contestation has ended" (Barry 2002: 272). However, Barry argues: "Measurement and calculation do not only have anti-political effects. They do not just have the effect of restricting political controversy... They also, at the same time, provide the basis for an opening up of new objects and sites of disagreement" (2002: 274). The case of the government of parades in Northern Ireland suggests two things; one, that the situation has not been successfully framed by governing bodies (and so become calculable in Callon's terms); and two, that calculation does not necessarily lead to depoliticization and reducing the space of politics. It is possible that the attempt to govern parades has had the opposite effect; that of bringing parade disputes even more into existence, or at least, to have created a new political space. Notified protests specifically against the PC and new forms of protests against parades (there have even been cases of protests notified against protests) is a good example. The attempt at calculation did not lead to a lack of contestation or normalization of 
desired conduct. Rather, new forms of struggle opened up. In his recent work on unionists, loyalists and conflict transformation, Smithey writes that "[a]nimosity towards the Parades Commission over the restrictions and rerouting of parades has become one of the primary outlets for expressing opposition to any erosion of the union" (2011: 125). As chapter seven has argued, the Parades Commission became the centre of contention and a focus point of resistance.

At the same time, there is evidence that the attention to parades has worked to foster increasing attempts to bring parading into the more mainstream public and cultural spheres. The Orange Order itself has done much to work towards 're-branding' its image and to reframe parading as an inclusive cultural festival open to everyone. Smithey writes that parading "is being reframed as opportunity for engagement" [with the wider public] on the part of the Orange Order. Instead of "projecting a defensive position, the Grand Lodge leadership of the Orange Order is developing its outreach capacity on a number of fronts, including parading” (2011: 125).

In the effort to improve its image, the organization has sought to make parades on July 12 appear more like a cultural festival through the launch of 'Orangefest' in 2007. Orangefest has involved attempts to attach greater historical and cultural meaning to the $12^{\text {th }}$ of July parades, to "emphasize its pageantry and entertainment value", and to "incorporate activities that are intended to convey an air of festivity" (Smithey 2011: 127). The project was conceived as early as 2003 (Smithey 2011: 127), and it has received government funding ${ }^{80}$ and support from business interests in Belfast city centre. ${ }^{81}$ The June-July 2008 visitors guide

\footnotetext{
${ }^{80}$ http://www.telegraph.co.uk/news/uknews/1522782/100000-for-Orange-parades-carnival.html ${ }^{81}$ In recent years, local businesses have worked to change the negative perceptions of Belfast's city centre on the Twelfth of July. Businesses have usually closed during the Twelfth weekend, as the main Orange parade route passes near the area. The 'Orangefest 2012 Business Feedback \& Event Report' states: "Much work has been undertaken since 2009 to promote Orangefest, including
} 
to Belfast contains a full page ad promoting Orangefest as a "family friendly pagent open to all, especially tourists and indeed anyone in multi-cultured Belfast on this day" (see Figure 6). The aspirations of the Orange Order to re-brand itself through parading align with state governing objectives and economic imperatives. Orangefest works to remove any sense of conflict and contention around parading and turns parading into an apolitical event. More than that, it works to turn the Order into an organization which celebrates pluralism. Such attempts signal the ways in which governing discourses may be appropriated and re-deployed by politically motivated actors pursuing their own agenda.

\section{Future directions and concluding thoughts}

The scope of this project was limited to providing an account of the practical and technical means through which the attempt was made to render a highly politicized symbolic practice into an administrable and calculable object. The project focused on highlighting the consequences of the governmental attempt, the challenges and resistances it engendered, and the difficulties governing a symbolic display in the context of political struggle. The case of parading in Northern Ireland ultimately speaks to the ways in which governing advances through the attempt to frame and invest social relations, consequent overflow, and experimental attempts at patch work. It has captured a slice or segment of governing practices and processes, as well as 'counter-conduct', over a relatively short period of time.

There are many threads that now remain to be pursued. In particular, a fruitful future line of inquiry might take a longer trajectory of state practices towards governing 'community relations' in Northern Ireland. It might examine the development of the peace

ensuring the city centre remained open. Continuing the marketing strategies used from 2009-2012, public information leaflets were made available in retail outlets, hotels and transport stations across the city centre... as well as in Belfast Visitor and Convention Bureau. ... The 2013 celebrations were, in part, helped by Peace III funding allocated for 2012 and 2013. This funding enabled a quality food market to take place in the grounds of City Hall, and funding of the Festival of Fools to provide on street entertainment, all aimed at attempting to promote a family-friendly atmosphere" (2013: 9). 
Figure 6 - 'Orangefest' advertisement

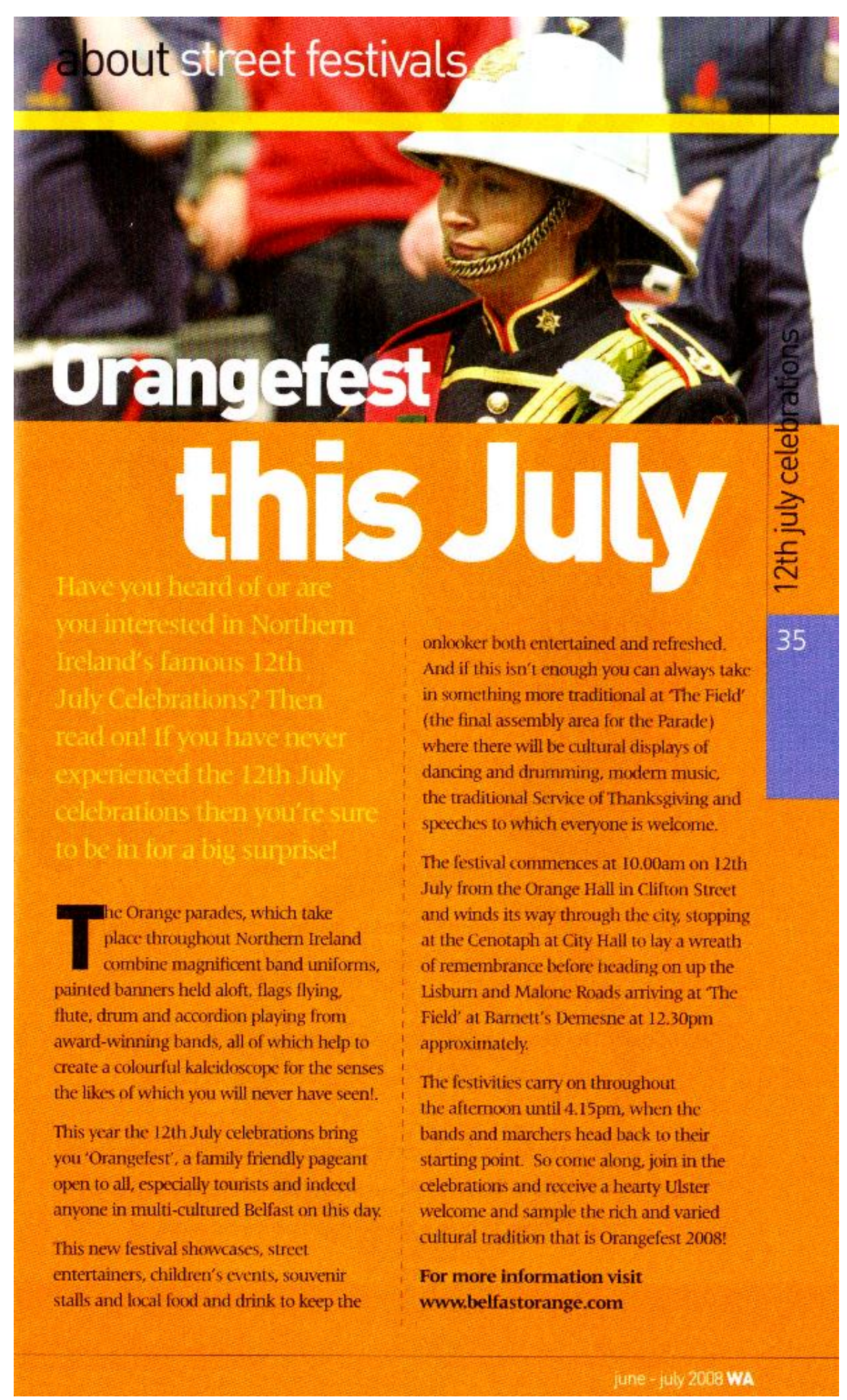

Source: Belfast Visitor and Convention Bureau, 'Whatabout' tourist guide, June-July 2008, pg. 35. 
process and its governing discourses, and analyze a broader range of endeavors which aim to govern political conflict through the constitution of 'two groups who just cannot get along'. Further, in line with the specific concern in this present project, future work might usefully situate the policies directed at parades within the development of the broader governmental concern with symbols as manifestations of sectarianism. As previously noted, the literature on state racism and anti-racism (Lentin 2004; Goldberg 2001), as well as anti-policy more generally (Walters 2008), provides a foundation to pursue such endeavors. Leading in this direction, I find Wendy Brown's (2006) work on tolerance a fitting way to conclude this thesis. Her argument opens up the space for future inquiry by offering a broader perspective on the discourses deployed in the government of parades, as well as in more recent policy for 'good relations' in Northern Ireland.

In March 2005, around the same time as the Ashdown review of parading was launched, the government published a policy document titled A Shared Future: Policy and Strategic Framework for Good Relations in Northern Ireland (OFMDFM 2005). After a period of consultation which ran between January and September 2003, the final document set out the government's vision and policy approach towards community relations, which was now renamed 'good relations'. In the report, the "underlying difficultly" was identified as "a culture of intolerance", which needs to be remedied "if we are to make Northern Ireland a more 'normal' society - the sort of society we would all be proud to live in" (OFMDFM 2005: 8). In the aims and objectives, the report states:

The overall aim of this policy is to establish, over time, a shared society defined by a culture of tolerance: a normal, civic society, in which all individuals are considered as equals, where differences are resolved through dialogue in the public sphere and where all individuals are treated impartially. A society where there is equity, respect for diversity and recognition of our interdependence. (10) 
The discourse of tolerance is central to the policy approach outlined in $A$ Shared Future (2005). Following Brown's work in Regulating Aversion (2006), tolerance may be understood as a political discourse and form of governmentality. She argues that tolerance is deployed as a "mode of depoliticizing and organizing the social". As a political discourse it is concerned with "designated modalities of diversity, identity, justice, and civic cohabitation". It involves "the enactment of social, political, religious, and cultural norms; certain practices of licensing and regulating; the marking of subjects of intolerance as inferior, deviant, or mariginal vis-à-vis those practicing tolerance...” (Brown 2006: 13). Depoliticization “involves construing inequality, subordination, marginalization, and social conflict, which all require political analysis and political solutions, as personal and individual". She argues that tolerance "tends to cast instances of inequality or social injury as matters of individuals or group prejudice", and as such, conflict is reduced to an "inherent friction" between essentialized identity groups. Depoliticization "always eschews power and history in the representation of its subjects" (Brown 2006: 15). When the practice of tolerance is substituted for justice and repairing historical inequalities, "then the field of political battle and political transformation is replaced with an agenda of behavioral, attitudinal, and emotional practices". Political action is reduced to "sensitivity training, or what Richard Rorty has called an 'improvement in manners'. A justice project is replaced with a therapeutic or behavioral one” (Brown 2006: 16).

The extent to which justice projects in Northern Ireland have been replaced with projects designed to instantiate individual and group tolerance practices is a question which merits further investigation. A certain amount of programmatic attention is paid to victims of violence, although much of it is around reconciliation between two groups, rather than acknowledgement of the state's role in the violence, and moreover, the state's role in the 
historical constitution of essentialized identity groups and in the development of the relationship between them. That question aside for the present, the way tolerance is deployed in $A$ Shared Future, much of what Brown argues applies. The very idea of tolerance essentializes two distinct identities, in this case, Protestants/loyalists/unionists and Catholics/nationalists/republicans, groups which, it is declared, must learn to live together. The premise of the document is that 'distinct and separate' is no longer an option. One of the central principles is that "the state must be neutral between competing cultural claims" (OFMDFM 2005: 9). Like in the many reviews of parading, the role of the state in the historical conflict is obscured, as the problem is represented as being clash of cultures.

While $A$ Shared Future wields the more broad discourse of tolerance, the discourse of engagement does work along similar lines, although more narrowly applied; it is a discourse specific to the management of a particular conflict between individuals or groups. Engagement too, essentializes two distinct identity groups, and cements their opposition one can only promote engagement between groups that are understood as separate. Also, as this dissertation has shown, fostering practices of engagement shifts the political field to be about relations between groups - in Brown's language, the regulation of parades was made to be about 'sensitivity training' (seen very well in Ashdown's parade notification form) or 'an agenda of behavioral, attitudinal, and emotional practices'. Parades policy consistently declares the problem as a lack of understanding of the other and one of perceptions.

Brown highlights that the work of tolerance is governmental rather than legal or judicial. She notes that tolerance may be a state or civic principle and figure prominently in policy documents, and it may conceptually underlie laws concerning freedom of religion, speech, and association, however, "tolerance as such is not legally or doctrinally codified". Brown states: 
Nor can it be, both because the meaning and work of tolerance is bound to its very plasticity - to when, where, and how far it will stretch - and because its legitimating goodness is tied to virtue, not to injunction or legality. Virtue is exercised and emanates from within; it cannot be organized as a right or rule, let alone commanded. (2006: 11-12)

Similarly, the desire to 'engage' had to come from within. There was a need for it to be 'genuine', and it was recognized that it was not something that could be legally mandated. Indeed, the work and value of engagement was in its application outside the legal field. The failure of the legal discourse of rights to bring about a shift in subjectivity is another example of how the desired changes were outside the realm of legal tactics. Deployed as abstract legal principles, the discourse of rights failed to foster 'recognition of the other'. Such internal transformations must be accomplished through the norm.

Brown writes: "[W] ithin secular liberal democratic states it is safe to say that tolerance functions politically and socially, but not legally, to propagate understandings and practices regarding how people within a nation, or regimes within an international system, can and ought to cohabit" (2006: 11). The discourse of engagement too is a political discourse and practice of governmentality when it is used to foster particular ways in which individuals and groups ought to relate and interact, and to a certain extent cohabit. Many of the reviews of parading tend towards this direction and work to further elaborate new procedures where 'engagement' may be better elicited, may be done 'genuinely', where emphasis is put on bolstering the process for 'local dialogue', and minimizing the role of formal determinations.

That said, it must be borne in mind that the present case is not a study of governmentality in a historically consensual society. Rather, as this dissertation has shown, the history of political conflict and the context of the peace process, which at the time was seen as fragile, shaped governing processes - mixed in with or alongside the behavioural and 
attitudinal project, the British government was occupied with finding consensus and with devising regulatory procedures that would satisfy political interests. Further, as noted earlier, in the context of Northern Ireland, governmental attempts directed at parading have not necessarily led to depoliticization, but rather, perhaps, to politicization in new forms. In either case, future work would usefully bring together theorizing on the discourses of tolerance and anti-sectarianism, with empirical study of how such discourses are deployed and taken up in the context of political struggle. 


\section{$\underline{\text { References }}$}

Alexander, Jeffery C. 2004. Cultural pragmatics: Social performance between ritual and strategy. Sociological Theory 22(4): 527-573.

Anderson, B. 1991. Imagined Communities: Reflection on the Origins and Spread of Nationalism. Revised Edition. London: Verso.

Baber, Mary. 1998. Public Processions in Northern Ireland. House of Commons Research Paper 98/11. House of Commons.

Barry, Andrew. 2002. The anti-political economy. Economy and Society 31: 268-84.

Bell, Desmond. 1990. Youth Culture and Sectarianism in Northern Ireland. Northern Ireland: Macmillan.

Bew, Paul and Gordon Gillespie. 1999. Northern Ireland: A Chronology of the Troubles 1968-1999. Dublin: Gill \& Macmillan.

Bennett, Tony. 1992. Putting policy into cultural studies. Pp. 23-37 in L. Grossberg, C. Nelson, and P. Treichler, eds., Cultural Studies. New York: Routledge.

Bennett, Tony. 1995. The Birth of the Museum: History, Theory, Politics. London: Routledge.

Bratich, Jack Z., Jeremy Packer, and Cameron McCarthy, eds. 2003. Foucault, Cultural Studies, and Governmentality. Albany/New York: SUNY Press.

Brown, Kris and Roger MacGinty. 2003. Public attitudes towards partisan and neutral symbols in post-Agreement Northern Ireland. Identities: Global Studies in Culture and Power 10: 83-108.

Brown. Wendy. 2006. Regulating Aversion: Tolerance in the Age of Identity and Empire. Princeton: Princeton University Press.

Bryan, Dominic. 2000. Orange Parades: The Politics of Ritual, Tradition and Control. London: Pluto Press.

Bryan, Dominic. 2006. The politics of community. Critical Review of International Social and Political Philosophy 9(4): 603-617.

Bryan, Dominic. 2006a. 'Traditional' parades, conflict and change: Orange parades and other rituals in Northern Ireland, 1960-2000. In Jörg Neuheiser and Michael Schaich, eds., Political Rituals in Great Britain: 1700-2000. Augsburg: Wissner-Verlag.

Bryan, Dominic. 2006b. The anthropology of ritual: monitoring and stewarding demonstrations in Northern Ireland. Anthropology in Action 13(1-2): 22-31. 
Bryan, Dominic, T.G. Fraser, and Seamus Dunn. 1995. Political Rituals: Loyalist Parades in Portadown. University of Ulster: Centre for the Study of Conflict.

Bryan, Dominic and Gordon Gillespie. 2005. Transforming Conflict: Flags and Emblems. Belfast: Institute of Irish Studies.

Bryan, Dominic and Gillian McIntosh. 2005. Sites of creation and contest in Northern Ireland. SAIS Review of International Affairs 25(2): 127-137.

Bryan, Dominic, and Michael Hamilton. 2006. Deepening democracy? Dispute system design and the mediation of contested parades in Northern Ireland. Obio State Journal on Dispute Resolution 22(1): 133-187.

Bryan, Dominic and Gillian McIntosh. 2007. Symbols and identity in the 'new' Northern Ireland. In Paul Carmichael, Colin Knox, and Robert Osborn, eds., Devolution and Constitutional Change in Northern Ireland. Manchester: Manchester University Press.

Bryan, Dominic, Clifford Stevenson, and Gordon Gillespie. 2008. Flags Monitoring Project 2007 Report. Belfast: Office of the First Minister and Deputy First Minister.

Bryan, Dominic, Clifford Stevenson, and Gordon Gillespie. 2009. Flags monitoring Project 2008/09: Interim Report Covering 2008, with Comparative Figures from 2006 and 2007. Belfast: Office of the First Minister and Deputy First Minister.

Bryan, Dominic, Clifford Stevenson, and Gordon Gillespie. 2010. The Public Display of Flags and Emblems in Northern Ireland. Belfast: Institute of Irish Studies.

Bryan, Dominic, Gordon Gillespie, John Bell, and Clifford Stevenson. 2011. Public Display of Flags and Emblems in Northern Ireland: Survey 2010. Belfast: Institute of Irish Studies.

Bryson, Lucy and Clem McCartney. 1994. Clashing Symbols? A report on the use of flags, anthems and other national symbols in Northern Ireland. Belfast: The Institute of Irish Studies.

CAJ (Committee on the Administration of Justice). 1996. The Misrule of Law: A Report on the Policing of Events During the Summer of 1996 in Northern Ireland. Belfast: CAJ.

Callon, Michel. 1998. An essay on framing and overflowing: Economic externalities revisited by sociology. In Michel Callon, ed., The Laws of the Markets. Oxford: Blackwell.

Christie, Pam. 2006. Changing regimes: Governmentality and education policy in postapartheid South Africa. International Journal of Educational Development 26: 373-381.

Coussins, Mark and Athar Hussain. 1986. The question of ideology: Althusser, Pecheux and Foucault. In John Law, ed., Power, Action and Belief: A New Sociology of Knowledge? London: Routledge and Kegan Paul. 
Curtis, Bruce. 2000. Social investment in medical forms: The 1866 cholera scare and beyond. The Canadian Historical Review 81(3): 1-35.

Curtis, Bruce. 2001. The Politics of Population: State Formation, Statistics, and the Census of Canada, 1840-1875. Toronto: University of Toronto Press.

Darby, John. 1976. Conflict in Northern Ireland: The Development of a Polarised Community. Dublin: Gill and Macmillan.

Davis, Susan G. 1986. Parades and Power: Street Theatre in Nineteenth-Century Philadelphia. Philadelphia: Temple University Press.

Dean, Mitchell. 1999. Governmentality: Power and Rule in Modern Society. London: Sage Publications.

Dean, Mitchell. 2010. Governmentality: Power and Rule in Modern Society. Second edition. London: Sage Publications.

Desrosières, Alain. 1990. How to make things which hold together: Social science, statistics and the state. Pp. 195-218 in P. Wagner, B. Wittrock, and R. Whitley, eds., Discourses on Society: Volume XV: The Shaping of the Social Science Disciplines. The Netherlands: Kluwer.

Dickson, Brice. 2010. The European Convention on Human Rights and the Conflict in Northern Ireland. Oxford: Oxford University Press.

Donohue, Laura K. 1998. Regulating Northern Ireland: The special powers acts, 1922-1972. The Historical Journal 41: 1089-1120.

Dubber, Markus D. and Mariana Valverde, eds. 2006. The New Police Science: The Police Power in Domestic and International Governance. Stanford, CA: Stanford University Press.

Farrell, Sean. 2000. Rituals and Riots: Sectarian Violence and Political Culture in Ulster 1784-1886. Lexington: University Press Kentucky.

Finlay, Andrew. 2010. Governing Ethnic Conflict: Consociation, Identity and the Price of Peace. New York: Taylor \& Francis.

Foucault, Michel. 1980. The confessions of the flesh. Pp. 194-228 in Colin Gordon, ed., Power/Knowledge: Selected Interviews and Other Writings 1972-1977 By Michel Foucault. Trans. Colin Gordon, Leo Marshall, John Mepham, and Kate Soper. New York: Pantheon Books.

Foucault, Michel. 1990. The History of Sexuality: An Introduction. Volume One. Trans. Robert Hurley. New York: Vintage.

Foucault, Michel. 1995. Discipline and Punish: The Birth of the Prison. Trans. Alan Sheridan. New York: Vintage. 
Foucault, Michel. 2003a. Governmentality. Pp. 229-245 in Paul Rabinow and Nikolas Rose, eds., The Essential Foucault: Selections From Essential Works of Foucault, 1954-1984. New York: The New Press.

Foucault, Michel. 2003b. Polemics, politics, and problematizations: An interview with Michel Foucault. Pp. 18-24 in Paul Rabinow and Nikolas Rose, eds., The Essential Foucault: Selections From Essential Works of Foucault, 1954-1984. New York: The New Press.

Foucault, Michel. 2003c. The subject and power. Pp. 126-144 in Paul Rabinow and Nikolas Rose, eds., The Essential Foucault: Selections From Essential Works of Foucault, 1954-1984. New York: The New Press.

Foucault, Michel. 2003d. Omnes et Singulatim. Pp. 180-201 in Paul Rabinow and Nikolas Rose, eds., The Essential Foucault: Selections From Essential Works of Foucault, 1954-1984. New York: The New Press.

Fraser, T.G., ed. 2000. The Irish Parading Tradition: Following the Drum. London: MacMillan.

Garland, David. 1997. 'Governmentality' and the problem of crime: Foucault, criminology, sociology. Theoretical Criminology 1(2): 173-214.

Goheen, P. G. 1993. The ritual of the streets in mid-19 ${ }^{\text {th }}$-century Toronto. Environment and Planning D: Society and Space 11: 127-45.

Goldberg, David. 2001. The Racial State. Malden, Mass.: Wiley-Blackwell.

Gordon, Alan. 2001. Making Public Pasts: The Contested Terrain of Montreal's Public Memories, 1891-1930. Montreal and Kingston: McGill-Queen's University Press.

Gordon, Colin. 1991. Governmental rationality: An introduction. Pp. 1-51 in Graham Burchell, Colin Gordon, and Peter Miller, eds., The Foucault Effect. Chicago: University of Chicago Press.

Graham, Brian and Catherine Nash. 2006. A shared future: Territoriality, pluralism and public policy in Northern Ireland. Political Geography 25: 253-278.

Grande Orange Lodge of Ireland. 1999 (circa). The Case Against the Parades Commission. Available: http://www.grandorangelodge.co.uk/The-case-against-the-paradescommission (Accessed August 20 2013).

Hadden, Tom and Anne Donnelly. 1997. The Legal Control of Marches in Northern Ireland. Belfast: Community Relations Council.

Hamilton, Michael. 1998. Parades Commission - Politically Correct? Consistency, Clarity and Compliance with the European Convention on Human Rights. Presentation to the Parades Commission. Unpublished document. 
Hamilton, Michael. 2001. Determining the right to march. Just News 16(6).

Hamilton, Michael. 2003. De-escalating parade disputes: Interpreting the European Convention on Human Rights. Report of the Democratic Dialogue Working Group on Freedom of Assembly. Belfast: Democratic Dialogue.

Hamilton, Michael. 2005a. Freedom of assembly, consequential harms and the rule of law: Liberty-limiting principles in the context of transition. Oxford Journal of Legal Studies 27(1): 75-100.

Hamilton, Michael. 2005b. Parade related protests: Is it the 'taking part' that counts? Just News 20(7): July/August.

Hamilton, Michael. 2007. Parading in Northern Ireland: Views of Key Stakeholders. Belfast: Strategic Review of Parading.

Hamilton, Michael, Neil Jarman, and Dominic Bryan. 2001. Parades, Protests and Policing: A buman Rights Framework. Belfast: Northern Ireland Human Rights Commission.

Hansard, Act 13-14 vic c.2. A Bill to Restrain Party Processions in Ireland.

Hansard, Volume 13 cc 717.

Hansard, Volume 108 cc 611-3.

Hansard, Volume 289 cc 507-22. Available: http://hansard.millbanksystems.com/commons/1997/jan/30/northern-ireland-paradesnorth-report\#column 508 (Accessed January 24 2011).

Heron, Craig and Steve Penfold. 1996. The craftsmen's spectacle: Labour day parades in Canada, the early years. Social History 29(58): 357-389.

Hill, Andrew and Andrew White. 2012. Painting peace? Murals and the Northern Ireland peace process. Irish Political Studies 27(1): 71-88.

Hillyard, Paddy and Mike Tomlinson. 2000. Patterns of policing and policing Patten. Journal of Law and Society 27(3): 394-415.

Hindess, Barry. 2004. Power, government, politics. In Kate Nash and Alan Scott, eds., The Blackwell Companion to Political Sociology. Oxford: Blackwell.

Human Rights Watch. 1997. To Serve Without Favour: Policing, Human Rights and Accountability in Northern Ireland. New York: Human Rights Watch.

Hunt, Alan. 1996. Governing the city: liberalism and early modern modes of governance. Pp. 167-188 in Andrew Barry, Thomas Osborne, and Nikolas Rose, eds., Foucault and Political Reason. Chicago: University of Chicago Press. 
Independent Research Solutions. 2009. Evaluation of the Re-imaging Communities Programme: $A$ Report to the Arts Council of Northern Ireland. June 2009. Belfast: Arts Council of Northern Ireland.

Jarman, Neil. 1993. Intersecting Belfast. Pp. 107-138 in Barbara Bender, ed., Landscape: Politics and Perspectives. Oxford: Berg.

Jarman, Neil. 1997. Material Conflicts: Parades and Visual Displays in Northern Ireland. Oxford: Berg.

Jarman, Neil. 1998. Material of culture, fabric of identity. In Daniel Miller, ed., Material Cultures: Why Some Things Matter. London: UCL Press.

Jarman, Neil. 1999. Regulating rights and managing public order: Parade disputes and the peace process, 1995-1998. Fordham International Law Journal 22(4): 1415-1439.

Jarman, Neil. 2000. For God and Ulster: Blood and thunder bands and loyalist political culture. Pp. 158-172 in T.G. Fraser, ed., The Irish Parading Tradition: Following the Drum. Basingstoke: Macmillan.

Jarman, Neil. 2003. From outrage to apathy? The disputes over parades, 1995-2003. Global Review of Ethnopolitics 3(1): 92-105.

Jarman, Neil and Dominic Bryan. 1996. Parade and Protest: A Discussion of Parading Disputes in Northern Ireland. University of Ulster: Centre for the Study of Conflict.

Jarman, Neil and Dominic Bryan. 1998. From Riots to Rights: Nationalist Parades in the North of Ireland. University of Ulster: Centre for the Study of Conflict.

Jarman, Neil, Dominic Bryan, Nathalie Caleyron, and Ciro de Rosa. 1998. Politics in Public: Freedom of Assembly and the Right to Protest - A Comparative Analysis. Belfast: Democratic Dialogue.

Jarman, Neil, Mary-Kathryn Rallings and John Bell. 2009. Local Accommodation: Effective Practice in Responding to Disputes over Parades. Belfast: Institute for Conflict Research.

Joint Group of Unionist MPs. 1987. Public Order Order: Equality Under the Law?

Kaufmann, Eric P. 2009. The Orange Order: A Contemporary Northern Irish History. Oxford: Oxford University Press.

Kelly, Grainne, ed. 1998. Mediation in Practice: A report of the Art of Mediation Project. Derry/Londonderry: INCORE.

Lentin, Alana. 2004. Racism and Anti-Racism in Europe. London: Pluto Press. 
Loughlin, James. 2000. Parades and politics: Liberal Governments and the orange order, 1980-1886. In T.G. Fraser, ed., The Irish Parading Tradition: Following the Drum. London: MacMillan.

McAllister, Brendan. 1998. The Difficult and the possible - mediation in Northern Ireland. Pp.15-21 in Grainne Kelly, ed. 1998. Mediation in Practice: A report of the Art of Mediation Project. Derry/Londonderry: INCORE.

McAllister, Brendan. 2000. Mediation and the Drumcree Conflict: The Potential for Intervention in 2000. A paper presented to the Parades Commission on 26 January 2000.

McAuley, Imelda. 1998. Reforming the law on contentious parades in Northern Ireland. Public Law. Spring, p. 44-56.

McGinty, Roger and John Darby. 2002. Guns and Government. New York: Palgrave.

McKay, Daithi. 2009. PSNI officers shown intimidating Rasharkin residents with loyalist bandsmen. Daithi McKay - Republicanism, Craic agus Scéal [blog], September 192007. Available: http://daithimckay.blogspot.ca/2009/09/psni-officers-shownintimidating.html (Accessed June 26 2012).

McVeigh, Robbie. 2002. Between reconciliation and pacification: The British state and community relations in the north of Ireland. Community Development Journal 37(1): 4759 .

Meath Peace Group Talks. 1995a. The Orange Order Today. St. Columban's College, Dalgan Park, Navan. 16 October 1995. [transcript]

Meath Peace Group Talks. 1995b. Orange Marches in Portadown: The Garvaghy Road Residents Perspective. St. Columban's College, Dalgan Park, Navan. 13 November 1995. [transcript]

Merlingen, Micheal and Rasa Ostrauskaite. 2005. Power/knowledge in international peacebuilding: The case of the EU police mission in Bosnia. Alternatives: global, local, political 30(3): 297-323.

Mowlam, Mo. 1997. Speech at the University of Ulster, Jordanstown, Northern Ireland. 17 October 1997. Available: http://cain.ulst.ac.uk/events/peace/docs/mm171097.htm (Accessed January 19 2011).

Newman, Simon Peter. 1997. Parades and the Politics of the Street: Festive Culture in the Early American Republic. Philadelphia: University of Pennsylvania Press.

Ní Aoláin, Fionnuala. 2000. The Politics of Force: Conflict Management and State Violence in Northern Ireland. Belfast: The Blackstaff Press. 
NIAC (Northern Ireland Affairs Select Committee). 2001a. Second Report: The Parades Commission. Volumes I: Report. HC 120-I. (11 April 2001). London: The Stationery Office.

NIAC (Northern Ireland Affairs Select Committee). 2001b. Second Report: The Parades Commission. Volumes II: Minutes of Evidence and Appendices. HC 120-II (19 July 2001). London: The Stationery Office.

NIAC (Northern Ireland Affairs Select Committee). 2005. The Parades Commission and Public Processions (Northern Ireland) Act 1998. Second Report of Session 2004-2005. Volume I: Report, together with formal minutes. HC 172-I. London: The Stationery Office.

NIO (Northern Ireland Office). 1998. The Agreement: Agreement Reached in the Multi-Party Negotiations. Belfast: NIO.

NIO (Northern Ireland Office). 2005. Mediation Measures for Parades in Northern Ireland: A Consultation Document. Belfast: NIO.

North Report. 1997. Report of the Independent Review of Parades and Marches. Belfast: The Stationary Office.

Northern Ireland Forum for Political Dialogue. 1997. Review of the Parades Issue in Northern Ireland by Standing Committee A (Public Order Issues). Volume 2. 20 June 1997.

Odysseos, Louiza. 2010. Human rights, liberal ontogenesis and freedom: Producing a subject for neoliberalism? Millennium: Journal of International Studies 28(3): 747-772.

OFMDFM (Office of the Minister and Deputy First Minister). 2005. A Shared Future: Policy and Strategic Framework for Good Relations in Northern Ireland. Belfast: OFMDFM.

OFMDFM (Office of the First Minister and Deputy First Minister). 2010. Public Assemblies, Parades and Protests in Northern Ireland: A Consultation Paper. Belfast: OFMDFM.

O’Malley, Pat, Lorna Weir, and Clifford Shearing. 1997. Governmentality, criticism, politics. Economy and Society. 26(4): 501-517.

Pat Finucane Centre. 1995. One Day in August. Derry: Pat Finucane Centre.

Pat Finucane Centre. 1996. In the Line of Fire. Derry: Pat Finucane Centre.

Quigley, Sir George. 2002. Review of the Parades Commission and Public Processions (Northern Ireland) Act 1998. Belfast: Sir George Quigley Review.

Rabinow, Paul. 2003. Anthropos Today: Reflections on Modern Equipment. Princeton: Princeton University Press.

Radforth, Ian. 2004. Royal Spectacle: The 1860 Visit of the Prince of Wales to Canada and the United States. Toronto: University of Toronto Press. 
Rider, Chris and Vincent Kearney. 2001. Drumcree: The Orange Order's Last Stand. London: Methuen.

Rolston, Bill. 1991. Politics and Painting: Murals and Conflict in Northern Ireland. London and Toronto: Associated Universities Press.

Rolston, Bill. 2012. Re-imaging: Mural painting and the state in Northern Ireland. International Journal of Cultural Studies 15(5): 447-466.

Rose, Nikolas. 1989. Governing the Soul: The Shaping of the Private Self. London: Routledge.

Rose, Nikolas. 1996b. Identity, genealogy, history. Pp. 128-151 in Stuart Hall and Paul du Gay, eds., Questions of Cultural Identity. London: Sage.

Rose, Nikolas. 1999. Powers of Freedom: Reframing Political Thought. Cambridge: Cambridge University Press.

Rose, Nikolas and Peter Miller. 1992. Political power beyond the State: Problematics of Government. British Journal of Sociology 43(2): 172-205.

Santino, Jack. 2001. Signs of W ar and Peace: Social Conflict and the Uses of Symbols in Public in Northern Ireland. Hampshire: Palgrave Macmillan.

Singer, Brian C.J. and Lorna Weir. 2006. Politics and sovereign power: Considerations on Foucault. European Journal of Social Theory 9(4): 443-465.

Smithey, Lee A. 2011. Unionists, Loyalists, and Conflict Transformation in Northern Ireland. New York: Oxford University Press.

Sokhi-Bulley, Bal. 2011. Government(ality) by experts: Human rights as governance. Law Critique 22: 251-271.

SRP (Strategic Review of Parading in Northern Ireland). 2008. Interim Consultative Report. Belfast: Strategic Review of Parading.

Stenson, Kevin. 1998. Beyond histories of the present. Economy and Society 27(4): 333-352.

Thévenot, Laurent. 1984. Rules and implements: Investment in forms. Social Science Information 23(1): 1-45.

Thompson, Simon. 2003. The politics of culture in northern Ireland. Political Studies Association Annual Conference. University of Leicester, April 2003.

Tikly, Leon. 2003. Governmentality and the study of education policy in South Africa. Journal of Education Policy 18(2): 161-174. 
UCAN (Ulster Community Action Network). 1996. Draft Report on Parade or Protest Conference, 8 and 9 November 1996. St Columbus Park House, Londonderry. [transcript]

Walters, William. 2008. Anti-policy and anti-politics: Critical reflections on certain schemes to govern bad things. European Journal of Cultural Studies 11(3): 267-288.

Walters, William. 2012. Governmentality: Critical Encounters. Abingdon/New York: Routledge.

Williams, Sue. The need to talk - internationally. Pp. 6-9 in Grainne Kelly, ed. 1998. Mediation in Practice: A report of the Art of Mediation Project. Derry/Londonderry: INCORE.

Young, Ian. 1998. Preface. Pp. 4-5 in Grainne Kelly, ed. 1998. Mediation in Practice: A report of the Art of Mediation Project. Derry/Londonderry: INCORE.

\section{Newspapers}

An Phoblact. 1998. Legal Challenges to the Parades Commission. February 26. Available: http://republican-news.org/archive/1998/February26/26par.html (Accessed August 6 2013).

Banbridge Chronicle. 2009. Clearance needed for townpath walk! October 28, pg. 11.

BBC News. 1997. The Ulster Marching Season. Available: http://www.bbc.co.uk/news/special/politics97/analysis/devenport.shtml (Accessed August 2 2013).

BBC News. 2009. DUP parades call 'unacceptable'. October 29. Available: http://news.bbc.co.uk/2/hi/uk_news/northern_ireland/8332843.stm (Accessed August 20 2013).

BBC News. 2010. Parties say 'progress' is being made at NI talks. January 30. Available: http://news.bbc.co.uk/2/hi/uk news/northern ireland/8488839.stm (Accessed August 20 2013).

BBC News. 2010. Draft parades laws 'in chaos' as Orange Order says 'no'. July 7. Available: http://www.bbc.co.uk/news/10534075 (Accessed August 13 2013).

BBC News. 2010. Changes are made to parades plan. August 12. Available: http://www.bbc.co.uk/news/uk-northern-ireland-10947917 (Accessed August 13 2013).

Belfast Telegraph. 1993. Plotting a new route to a different image. July 8.

Belfast Telegraph. 2008. A jumbo problem for Commission. October 22, pg. 4.

Belfast Telegraph. 2008. Now Parades Commission must rule on Santa's fate, Father Christmas has to ask for permission like everyone else. November 1, pg. 3. 
Belfast Telegraph. 2009. Orangemen cry fowl over turkeys, Stop chickening out over Drumcree, Parades Commission urged. January 5, pg. 9.

County Down Spectator. 2008. Elephant row rumbles on. October 30, pg. 7.

Irish News. 1993. Cardinal urges Orangemen to 'march with dignity'. July 10.

Irish News. 2006. No talk, no walk - parades body. Available: http://www.nuzhound.com/articles/irish_news/arts2006/aug18 no talk_no_walk. php (Accessed August 2 2013).

Larne Times. 2008. Vintage car club stalled by Parades Commission rules. October 30, pg. 15.

Mourne Observer. 2008. Old Vehicle Clubs should be exempt from parading laws - Council. October 29, pg. 15.

NewsLetter. 2011. Loyalist might defy march ruling of parades body. June 15. Available: http://www.newsletter.co.uk/news/local/loyalists-might-defy-march-ruling-ofparades-body-1-2773106 (Accessed July 3 2012).

Sunday Tribune. 1998. Nationalist's predict major conflict in Drumcree. March 1. Available: http://www.nuzhound.com/articles/mal32-1.htm (Accessed August 5 2013).

\section{$\underline{\text { Parades Commission Documents }}$}

Parades Commission. 1998. Public Processions and Parades: A Code of Conduct. Belfast: Parades Commission.

Parades Commission. 1998. Public Processions and Parades: Procedural Rules. Belfast: Parades Commission.

Parades Commission. 1998. Public Processions and Parades: Guidelines. Belfast: Parades Commission.

Parades Commission. 1998. The Belle Isle Weekend: The Outcomes. 6 October 1998. Unpublished document.

Parade Commission. 2006. Parading in a Peaceful Northern Ireland: Forward View and Review of Procedures. Belfast: Parades Commission. Available: http://www.paradescommission.org/fs/doc/publications/pc-wayforward.pdf

Parades Commission. 2010. Draft Public Assemblies, Parades and Protests (Northern Ireland) Bill: A Response from the Parades Commission for Northern Ireland. Belfast: Parades Commission. Available: http://www.paradescommission.org/fs/doc/publications/responsefrom-the-pc-for-ni.pdf 


\section{Annual Reports (AR)}

Parades Commission. 1999. Annual Report of the Parades Commission 1998-1999. Belfast: The Stationary Office.

Parades Commission. 2000. Second Annual Report of the Parades Commission 1999-2000. London: The Stationary Office.

Parades Commission. 2001. Third Annual Report 2000-2001. London: The Stationary Office.

Parades Commission. Fourth Annual Report, 1 April 2001- 31 March 2002. Belfast: Parades Commission.

Parades Commission. 2009. Annual Report and Financial Statements: Parades Commission for Northern Ireland for the year ended 31 March 2008. London: The Stationary Office.

Parades Commission. 2010. Annual Report and Financial Statements: Parades Commission for Northern Ireland for the year ended 31 March 2009. London: The Stationary Office.

\section{Determinations}

Parades Commission. 1998. [Armagh] Determination in Relation to the Armagh District LOL No 5 parades on 13 July 1998. Belfast: Parades Commission.

Parades Commission. 1998. [Bellaghy] A Consideration of Contentious Parades by the Parades Commission. Belfast: Parades Commission.

Parades Commission. 1998. [Crumlin] A Consideration of Contentious Parades by the Parades Commission. Includes the Decision in Relation to the Glenavy District LOL and Crumlin LOL Parades on 13 July 1998. Belfast: Parades Commission.

Parades Commission. 1998. [Dunloy] Consideration of Contentious Parades. Includes the Determination in Relation to the Dunloy Apprentice Boys Church Parade on Sunday 17 May 1998. Belfast: Parades Commission.

Parades Commission. 1998. [Lower Ormeau Road] A Consideration of Contentious Parades by the Parades Commission and Determination in Relation to the Belfast Walker Club of the Apprentice Boys of Derry Easter Monday Parade (13 April 1998). Belfast: Parades Commission.

Parades Commission. 1998. [Pomeroy] A Consideration of Contentious Parades by the Parades Commission. Includes Determinations in Relation to Pomeroy District LOL NO 5 parades on 12 and 13 July 1998. Belfast: Parades Commission.

Parades Commission. 1998. [Portadown] The Parades Commission's Decision in Relation to the Portadown District LOL NO 1 Church Parade on 5 July 1998. Belfast: Parades Commission. 
Parades Commission. 1998. [Tour of the North] Belfast: The 'Tour of the North'. The Parades Commission's Decision. Belfast: Parades Commission.

Parades Commission. 2003. [Castlewellan] Determination Made in Relation to the Castlewellan Star of Temperance LOL 356 Parade Notified to Take Place in Castlewellan on Saturday 12 July 2003. Belfast: Parades Commission.

Parades Commission. 2004. [Portadown] Determination Made in Relation to the 36th (Ulster) Regimental Bands Association Parade Notified to Take Place in Portadown on Saturday 25 September 2004. Belfast: Parades Commission.

Parades Commission. 2006. [Ballynafeigh]. Determination Made in Relation to the Ballynafeigh District LOL No 10 Parade Notified to Take Place in Belfast on Sunday 30 April 2006. Belfast: Parades Commission.

Parades Commission. 2007. [Portadown]. Determination Made in Relation to the Portadown District LOL No 1 Parade Notified to Take Place in Portadown on Sunday, 22 July 2007. Belfast: Parades Commission.

Parades Commission. 2008. [Portadown]. Determination Made in Relation to the Portadown District LOL No 1 Parade Notified to Take Place in Portadown on Sunday, 4 May 2008. Belfast: Parades Commission.

Parades Commission. 2008. [Stoneyford] Determination Made in Relation to the Parade by the Pride of the Village Flute Band, Stoneyford, Notified to take Place in Stoneyford on Wednesday, 22 October 2008. Belfast: Parades Commission.

Parades Commission. 2009. [Keady] Determination Made in relation to the Parade-Related Protest by Keady Residents Association Notified to Take Place in Keady on Sunday, 12 July 2009. Belfast: Parades Commission.

Parades Commission. 2009. [Downpatrick] Determination Made in relation to the Red Hand Defenders Flute Band Parade Notified to Take Place in Downpatrick on Monday 3 August 2009. Belfast: Parades Commission. 